\title{
Tradycyjnie czy nowocześnie? Wzory macierzyństwa i ojcostwa w Polsce
}


盗 
Krystyna Dzwonkowska-Godula

Tradycyjnie

czy nowocześnie?

Wzory macierzyństwa

i ojcostwa w Polsce

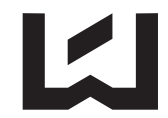

WYDAWNICTWO

UNIWERSYTETU

ŁÓDZKIEGO

ŁóDŹ 2015 
Krystyna Dzwonkowska-Godula - Uniwersytet Łódzki, Wydział Ekonomiczno-Socjologiczny

Zakład Socjologii Płci i Ruchów Społecznych

90-255 Łódź, ul. Polskiej Organizacji Wojskowej 3/5

\author{
RECENZENT \\ Anna Titkow \\ OPRACOWANIE REDAKCYJNE \\ Małgorzata Szymańska \\ SKŁAD I ŁAMANIE \\ Munda-Maciej Torz \\ PROJEKT OKŁADKI \\ Łukasz Orzechowski
}

Zdjęcie wykorzystane na okładce: (C) Depositphotos.com/sirastockid08

C Copyright by Uniwersytet Łódzki, Łódź 2015

Wydane przez Wydawnictwo Uniwersytetu Łódzkiego

Wydanie I. W.06820.15.0.M

Ark. wyd. 17,0; ark. druk. 14,875

ISBN 978-83-7969-834-9

e-ISBN 978-83-7969-835-6

Wydawnictwo Uniwersytetu Łódzkiego

90-131 Łódź, ul. Lindleya 8

www.wydawnictwo.uni.lodz.pl

e-mail: ksiegarnia@uni.lodz.pl

tel. (42) 6655863 


\section{Spis treści}

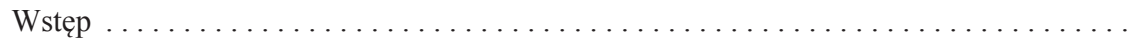

\section{CZĘŚĆ I}

TEORETYCZNE MODELE I KULTUROWE KONTEKSTY MACIERZYŃSTWA I OJCOSTWA

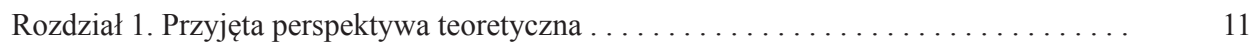

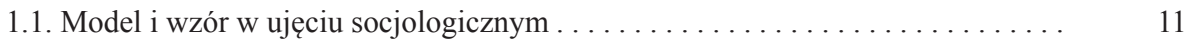

1.2. Rola społeczna w wybranych teoriach socjologicznych ............... 14

1.3. Podmiotowość jednostek w teorii strukturacji Anthony'ego Giddensa . . . . . . . . 19

1.4. Wybrana koncepcja roli społecznej w perspektywie teorii strukturacji. . . . . . 30

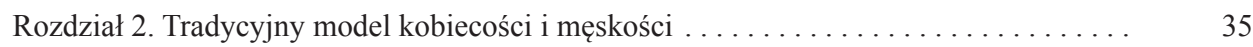

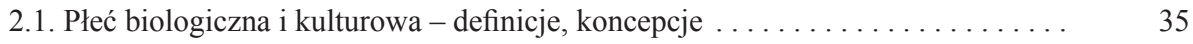

2.2. Polaryzacja płci w tradycyjnym modelu kobiecości i męskości ........... 50

2.3. Macierzyństwo i ojcostwo w tradycyjnym modelu kobiecości i męskości ..... $\quad 57$

Rozdział 3. Nowoczesny model kobiecości i męskości . . . . . . . . . . . . . . 67

3.1. „Depolaryzacja rodzajów” i zmiana relacji płci................. 67

3.2. Macierzyństwo i ojcostwo w nowoczesnym modelu kobiecości i męskości.... $\quad 79$

3.3. Spory wokół nowoczesnego modelu płci kulturowej oraz macierzyństwa

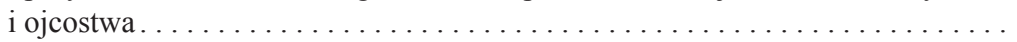

Rozdział 4. Modele i wzory kobiecości i męskości, macierzyństwa i ojcostwa funkcjonujące

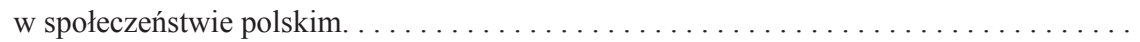

4.1. Współczesne polskie społeczeństwo jako kontekst podmiotowych działań jednostek. Koncepcja roli matki i roli ojca w polskiej polityce rodzinnej . . . . . .

4.2. Kobiecość, męskość, macierzyństwo i ojcostwo w katolickiej nauce społecznej ..

4.3. Modele i wzory macierzyństwa i ojcostwa w Polsce w świetle wyników badań

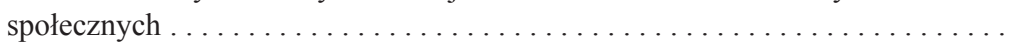

\section{CZECŚĆ II}

WZORY RODZICIELSTWA MŁODYCH WYKSZTAŁCONYCH POLEK I POLAKÓW. WYNIKI EMPIRYCZNYCH BADAŃ WŁASNYCH

Rozdział 5. Cel, problematyka i założenia metodologiczne badań własnych .........

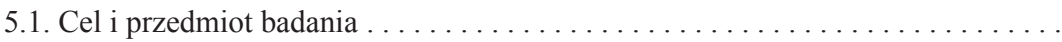

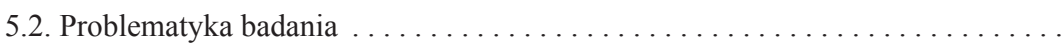

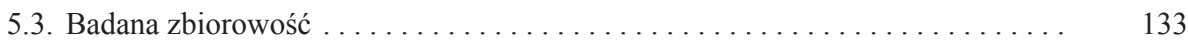

5.4. Metoda i techniki badawcze . . . . . . . . . . . . . . . . . . . . 134

5.5. Refleksje i uwagi badaczki. . . . . . . . . . . . . . . . . . . . . . . . . . 139 
Rozdział 6. Kobiecość i męskość w świadomości młodych wykształconych Polaków. . . . 145

6.1. Sposób definiowania kobiecości i męskości przez uczestników badania . . . . . . .

6.2. Postrzeganie macierzyństwa i ojcostwa jako elementów roli kobiety i mężczyzny w świetle wypowiedzi respondentów $\ldots \ldots \ldots \ldots \ldots \ldots \ldots \ldots \ldots \ldots$

6.3. Konkluzje.

Rozdział 7. Wzory roli matki i roli ojca realizowane przez młodych wykształconych

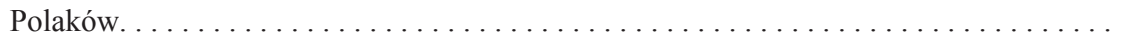

7.1. Sposób definiowania macierzyństwa i ojcostwa przez badanych

7.2. Rodzicielstwo młodych wykształconych Polaków - partnerstwo czy podział ról? . .

7.3. Role matki i ojca w rodzinach pochodzenia uczestników badania .

7.4. Konkluzje.

Rozdział 8. Macierzyństwo i ojcostwo jako nowe doświadczenie kobiety i mężczyzny. . .

8.1. Zostanie rodzicem jako przełomowy moment w życiu kobiet i mężczyzn . . . . . .

8.2. „Jestem matką”, ,jestem ojcem” - kobiety i mężczyźni o zmianach w sposobie

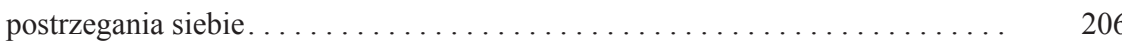

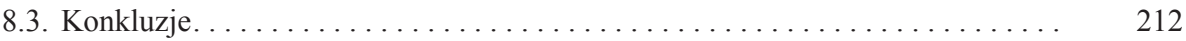

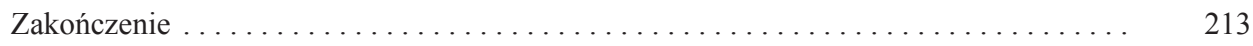

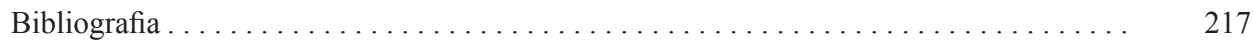

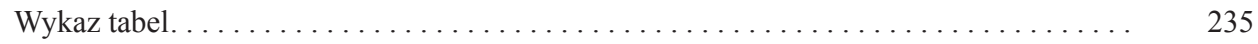

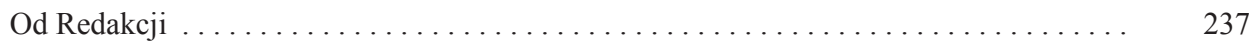




\section{Wstęp}

We współczesnym społeczeństwie ścierają się dwa kulturowe modele kobiecości i męskości: tradycyjny, oparty na polaryzacji płci, wyznaczający jednostkom określone role płciowe, oraz nowoczesny, zacierający różnice między kobiecością i męskością, pozwalający na bycie kobietą/mężczyzną na swój własny sposób. Przekształceniu i przedefiniowaniu podlegają też ściśle związane z kobiecością i męskością koncepcje macierzyństwa i ojcostwa. W nowoczesnym modelu kobiety realizują się na innych płaszczyznach niż tylko domowa i rodzinna, rola matki przestaje być ich „przeznaczeniem”, mężczyźni natomiast zaczynają odkrywać nowy - emocjonalny, „macierzyński” wymiar ojcostwa. Jak pokazują wyniki badań, polskie społeczeństwo jest $\mathrm{w}$ dużej mierze tradycyjne w definiowaniu kobiecości i męskości. Płciowe stereotypy i podział ról ze względu na płeć są mocno utrwalone w społecznej świadomości (Roszak 2015; CBOS 2013a; Titkow, Duch-Krzystoszek 2009; Piszczatowska, Szczepańska 2008; Baranowska 2007; Siemieńska 2007a; Titkow i in. 2004a). Stosunkowo najbardziej ,,nowoczesne poglądy" w tej kwestii mają młodzi wykształceni ludzie, preferujący partnerski model rodziny i odrzucający tradycyjnie zdefiniowane role płciowe (tamże). Powstaje jednak pytanie, czy równie nowocześni są w swoich codziennych zachowaniach, w pełnionych przez siebie rolach we własnych rodzinach.

Celem autorki niniejszej książki jest analiza wzorów macierzyństwa i ojcostwa realizowanych przez młode wykształcone Polki i Polaków oraz odpowiedź na pytanie, czy mają one tradycyjny czy nowoczesny charakter. Płaszczyzną odniesienia są kulturowe modele kobiecości i męskości (tradycyjny i nowoczesny), obejmujące przypisywane kobietom i mężczyznom cechy, zachowania i role społeczne, ze szczególnym zwróceniem uwagi na role rodzicielskie, bowiem macierzyństwo i ojcostwo stanowi istotny element repertuaru ról płciowych. $\mathrm{Na}$ podstawie dostępnej literatury przedmiotu stworzono idealne typy tradycyjnego i nowoczesnego modelu płci, wraz z zawierającymi się w nich modelami macierzyństwa i ojcostwa. Porównano je z przekonaniami i doświadczeniami związanymi z pełnieniem roli matki i ojca przez młode wykształcone Polki i Polaków, by odpowiedzieć na pytanie, czy realizowane przez nich wzory macierzyństwa i ojcostwa odpowiadają tradycyjnemu czy też nowoczesnemu modelowi płci kulturowej.

Ze względu na zakres przedsięwzięcia badawczego niezbędne było przeanalizowanie bogatego dorobku naukowego poświęconego problematyce płci kulturowej oraz ról rodzicielskich. W rezultacie książka została podzielona na dwie części. Pierwsza, obszerniejsza część prezentuje teoretyczne i kulturowe konteksty macierzyństwa i ojcostwa. Ramy teoretyczne prowadzonych rozważań oraz zrealizowanych badań stanowiła teoria strukturacji Anthony’ego Giddensa, 
traktująca świat społeczny - w tym role płciowe i rodzicielskie - jako wytwór podmiotowej działalności ludzi. Do opisu badanej rzeczywistości społecznej zastosowano pojęcia modelu i wzoru oraz roli społecznej, rozumianej tu jako „praktyka społeczna”, odwołująca się do „strukturalnych przepisów”, ale przede wszystkim będąca wyrazem określonych przekonań i zachowań jednostek - nie tyle odtwórców, co twórców pełnionych ról. Część teoretyczna przybliża Czytelnikowi zagadnienie płci kulturowej (gender) i różnych jej wymiarów jako przedmiotu socjologicznych rozważań i analiz. Nabiera to szczególnego znaczenia w sytuacji mylenia pojęć naukowych z ideologią we współczesnym dyskursie publicznym w Polsce. Zaprezentowane zostały główne założenia tradycyjnego oraz nowoczesnego modelu płci wraz z charakterystyką kobiecości i męskości, a następnie - macierzyństwa i ojcostwa. Kluczowe było tu pokazanie kulturowego wymiaru płci i rodzicielstwa oraz ścisłego związku między koncepcjami roli matki i ojca a koncepcjami kobiecości i męskości, a także ich przemianami.

Sporo miejsca poświęcono charakterystyce warunków społeczno-kulturowych, w których mogła dokonać się zmiana modelu płci oraz rozważaniom na temat różnego rodzaju kontrowersji i niejasności, jakie niesie ze sobą nowoczesne podejście do płci, a także trudności, na jakie napotykają jednostki funkcjonujące w czasach ścierania się tradycji z nowoczesnością w określaniu kobiecości i męskości, macierzyństwa i ojcostwa. Rozdział czwarty, zamykający tę część pracy, przedstawia społeczny kontekst, w jakim badani - młodzi wykształceni Polacy - realizują role rodzicielskie. Zwrócono uwagę na cechy polskiego społeczeństwa sprzyjające podmiotowości jego członków. Przyjmując założenie o istotnej roli państwa oraz instytucji Kościoła w kształtowaniu kulturowych modeli płci, przeanalizowano koncepcję roli matki i ojca w polskiej polityce rodzinnej oraz sposób definiowania płci i relacji płciowych na gruncie katolicyzmu jako dominującej w Polsce religii. Zaprezentowano także modele i wzory obecne w polskim społeczeństwie, zrekonstruowane na podstawie analizy wyników badań poświęconych sposobom postrzegania kobiecości, męskości, macierzyństwa i ojcostwa przez Polaków oraz ich rzeczywistym zachowaniom w tych rolach.

Opracowanie teoretycznych modeli płci i rodzicielstwa w ujęciu tradycyjnym i nowoczesnym oraz charakterystyka wyżej wskazanych aspektów polskiego społeczeństwa stanowiły punkt wyjścia dla realizacji badania wzorów macierzyństwa i ojcostwa młodych wykształconych Polek i Polaków. Prezentacji koncepcji badawczej oraz wyników badania poświęcona została druga część książki. Omówione zostały: sposoby definiowania kobiecości i męskości przez uczestników badania oraz ich przekonania na temat znaczenia macierzyństwa i ojcostwa jako immanentnych elementów ról płciowych; sposoby postrzegania i realizowania przez nich ról matki i ojca oraz dzielenia zadań związanych z opieką nad dzieckiem, a także zagadnienie genezy wzorów ról rodzicielskich w oparciu o wypowiedzi respondentów na temat ich stosunku do wzorów roli matki i ojca realizowanych $\mathrm{w}$ ich rodzinach pochodzenia. $\mathrm{W}$ ostatnim rozdziale przedmiotem analizy 
jest macierzyństwo i ojcostwo jako nowe doświadczenie kobiety i mężczyzny, a dokładnie zmiany (w życiu oraz w sposobie postrzegania siebie), jakich doświadczają młodzi rodzice. Celem było porównanie kobiecego i męskiego odczuwania zmian, jakie niesie ze sobą zostanie matką/ojcem oraz pokazanie wspólnotowości doświadczania rodzicielstwa.

$\mathrm{W}$ badaniu ról rodzicielskich zastosowano nowe podejście polegające na jednoczesnym uwzględnieniu kobiecej i męskiej perspektywy, analizowaniu roli matki i ojca w diadzie, wzajemnej relacji. W naukowym dorobku poświęconym rodzicielstwu dominują opracowania koncentrujące się albo na macierzyństwie, albo na ojcostwie. Jeśli nawet przedmiotem analizy były obie role rodzicielskie to $\mathrm{i}$ tak niejako w oderwaniu od siebie, jakby funkcjonowały one obok siebie, a nie w ścisłym związku (Sikorska 2009a). W badaniu własnym zestawiono ze sobą kobiece i męskie doświadczenie bycia rodzicem, skonfrontowano je ze sobą (w dosłownym sensie, gdyż wywiady przeprowadzano jednocześnie z matką i ojcem). Zakładano bowiem, że tylko w ten sposób uzyskać można ich pełen obraz. Ponieważ role te są ze sobą ściśle związane, pełnione w ramach jednej grupy, jaką jest rodzina, powinny być analizowane razem. Określone postawy, zachowania, zadania matek zależą po części od konkretnych zadań, postaw i zachowań ojców, i odwrotnie. Role te są w ramach związku kobiety i mężczyzny każdorazowo na nowo przedefiniowywane, negocjowane.

Nowatorskość zrealizowanego projektu badawczego polega na wykorzystaniu w badaniu rodzicielstwa techniki podwójnego wywiadu. Młodzi rodzice opowiadali badaczowi, ale i sobie nawzajem, o znaczeniu narodzin dziecka w ich życiu, rozumieniu przez siebie macierzyństwa i ojcostwa, różnych aspektach realizowanych ról rodzicielskich. Było to badanie wspólnie realizowanego i doświadczanego rodzicielstwa kobiety i mężczyzny, którzy w sytuacji wywiadu uzgadniali znaczenia dotyczące kobiecości i męskości, macierzyństwa i ojcostwa, ich wzajemnej relacji i relacji z dzieckiem, codziennego wspólnego życia. Choć podwójny wywiad nie jest wolny od ograniczeń, pozwala na nowe spojrzenie na rodzicielstwo kobiety i mężczyzny, inne niż w rezultacie osobnej rozmowy z każdym $\mathrm{z}$ rodziców.

Badanie o charakterze jakościowym zrealizowano w 2007 roku. Może to rodzić podejrzenia, że w związku z szybko zmieniającą się społeczną rzeczywistością zebrane dane i rozważania w książce są już nieaktualne i należy traktować je jako „historyczne”. Jednak najnowsze wyniki badań dotyczących na przykład preferowanych modeli rodziny oraz podziału obowiązków domowych i rodzicielskich (CBOS 2013a) pokazują, że wciąż funkcjonujemy pomiędzy tradycją a nowoczesnością, zarówno jeśli chodzi o sposób postrzegania roli kobiety i mężczyzny, jak i roli matki i ojca. Duża część Polaków jest przekonana, ,że kobiety lepiej niż mężczyźni nadają się do opieki nad dziećmi”, mają bowiem instynkt macierzyński i naturalne predyspozycje do zajmowania się potomstwem (Roszak 2015). Mężczyźni w bardzo niewielkim stopniu korzystają z przysługujących im 
urlopów rodzicielskich (Chełstowska, Zarzyńska 2014; Kostrzewski, Miączyński 2014). Spory o to, co znaczy dziś być kobietą i mężczyzną, matką i ojcem oraz jak mają wyglądać relacje między tymi społecznymi rolami nadal trwają. W społecznym dyskursie zwolennicy nowoczesnego definiowania kobiecości i męskości oraz równości płci ścierają się z tradycjonalistami, widzącymi we wszelkich zmianach i w samej koncepcji płci kulturowej (gender) zagrożenie dla rodziny i właściwego ich zdaniem porządku społecznego, w którym każdy - jako kobieta i mężczyzna - ma swoje miejsce i rolę. Niniejsza książka pozwala przyjrzeć się sposobowi myślenia młodych wykształconych Polek i Polaków o kobiecości i męskości, macierzyństwie i ojcostwie oraz ich rodzicielskim praktykom. Być może pozwoli też zrozumieć, dlaczego w polskim społeczeństwie nowoczesny model płci oraz rodzicielstwa nie jest czymś powszechnym, a model tradycyjny „trzyma się mocno”. 


\section{CZECŚĆ I \\ TEORETYCZNE MODELE I KULTUROWE KONTEKSTY MACIERZYŃSTWA I OJCOSTWA}

\section{Rozdział 1. Przyjęta perspektywa teoretyczna}

\subsection{Model i wzór w ujęciu socjologicznym}

Jak stwierdza Antonina Kłoskowska, ,społeczne zachowania ludzi mają charakter kulturowy, tzn. są określone przez wzory i modele działania właściwe jakiejś kulturze [podkr. K.D.-G.]" (Kłoskowska 2007: 140). Właśnie modele i wzory odnoszące się do bycia kobietą, mężczyzną, matką, ojcem stanowią tematykę niniejszej książki. Pojęcia te, nie zawsze jednakowo rozumiane na gruncie socjologii i innych nauk społecznych, wymagają zdefiniowania.

Pojęcie wzoru, stosowane częściej niż pojęcie modelu, pojawia się przede wszystkim w opracowaniach z zakresu antropologii czy socjologii kultury, poświęconych analizie treści kultury. Mówi się o „wzorach kulturowych” i „społecznych”, „wzorach zachowań”, „wzorach interakcji” itp., traktując je jako „standardy zachowania” czy „stereotypowe formy zachowania” występujące w danym społeczeństwie (Linton 2000: 33, 38). U podstaw ich tworzenia leży zgoda członków społeczeństwa co do sposobu zachowania się w określonej sytuacji, czy w związku z zajmowaniem takiej a nie innej pozycji społecznej (tamże: 33, 34). Jak stwierdza Jan Szczepański, ,[...] wzór kulturalny określa sposób zachowania uznany za «normalny» $\mathrm{w}$ danej sytuacji, normalny, tzn. uznawany w danej grupie, lub lepiej wzór określa zakres zachowań dopuszczalnych i skutecznych $\mathrm{w}$ tej sytuacji. Wzory są więc czynnikiem ujednolicającym postępowanie ludzi, ułatwiającym porozumienie i zrozumienie cudzych zachowań oraz skuteczność wzajemnych oddziaływań” (Szczepański 1970: 101). Zwraca się uwagę, że „,...] każdy rzeczywisty wzór kulturowy nie jest pojedynczym zachowaniem, lecz serią zachowań różniących się w pewnych granicach. [...] Zatem różne jednostki mogą zachowywać się rozmaicie, zachowując się zarazem wciąż jeszcze zgodnie z rzeczywistym wzorem kulturowym" (Linton 2000: 61, 63). Te schematy postępowania w określonych sytuacjach stosowane są najczęściej bezwiednie i nieświadomie, automatycznie. Jednostki poznają prawidłowości zachowania się w procesie socjalizacji, dzięki czemu potrafią przewidywać zachowania innych i odpowiednio na nie reagować, co z kolei jest podstawą funkcjonowania 
i trwałości społeczeństwa. Trzeba jednak zaznaczyć, że ludzie nie pozostają biernymi „realizatorami” kulturowych wzorów, to oni bowiem dokonują zmian w ich ramach, odrzucają schematy działania trudne czy niewygodne do zastosowania w zmieniającym się otoczeniu społecznym i wprowadzają nowe (Linton 2000: 37; Benedict 1999: 311).

Pojęcie wzoru nie zawsze jest stosowane do określenia ustalonych w danym społeczeństwie schematów postępowania. Maria Ossowska definiuje wzór jako „,coś, co staramy się osiągnąć”, „przedmiot naśladownictwa”, wiążąc taki sposób rozumienia tego pojęcia z pochodzącym od rzeczownika „wzór” czasownikiem „wzorować się" (Ossowska 2000: 11). Wzór postępowania w rozumieniu M. Ossowskiej bliski jest zatem pojęciu normy (Ossowska 2005: 112).

Antonina Kłoskowska, której koncepcję wykorzystano w niniejszej pracy, dla określenia zachowań idealnych, pożądanych w danej kulturze, wprowadza pojęcie modelu. Autorka, proponując rozróżnienie między modelami i wzorami, nawiązuje do koncepcji Floriana Znanieckiego modeli ideologicznych (normatywnych) i realizowanych wzorów czynności (Kłoskowska 2007: 113-114). Autor ten zwrócił uwagę na mieszanie przez badaczy uznawanych w danym społeczeństwie „powinności” (wartości i norm) z realnym ich stosowaniem w działaniu. „Etnologowie, odtwarzając wzorce wartości i normy postępowania na podstawie wypowiedzi miarodajnych uczestników kultury, nierzadko explicite nazywają te wzorce i normy «wzorami działania» lub «wzorami postępowania». [...] Uznanie obligatoryjnego charakteru wzorców i norm jest czymś tak różnym od ich praktycznego stosowania, że niezbędne wydaje się wprowadzenie rozróżnienia terminologicznego. Definicję sytuacji zawierającą w sobie wzorzec wartości i normę postępowania będziemy nazywali modelem postaw lub, dokładniej, ideologicznym modelem postaw. Jest to model w tym znaczeniu, że ma służyć za doskonały przykład słusznego myślenia o sytuacji, jakiej dotyczy. Od antropologów kulturowych zapożyczymy termin wzór czynności lub, dokładniej, realny wzór czynności na określenie swoistego ładu wewnętrznego, wynikającego z praktycznego zastosowania wzorców i norm, który sprawia, iż pewne czynności są podobne lub różne od innych czynności” (Znaniecki 1971: 464, 465). Korzystając z propozycji F. Znanieckiego, A. Kłoskowska traktuje wzory społeczne jako prawidłowości, regularności ludzkich zachowań, ich powtarzalną strukturę, schematy według których ludzie działają w określonych sytuacjach, typowe dla danej grupy sposoby zachowania (Kłoskowska 1959: 48). Modele natomiast definiuje jako „postulowane zasady aprobowanego w danej kulturze zachowania”, „zalecenia, odnoszące się do pełnienia określonych ról społecznych i do zachowania w różnych społecznych sytuacjach, sformułowane w postaci zdań normatywnych lub zdań opisowych zawierających wyraźne oceny" (Kłoskowska 1980: 32, 33). Autorka podkreśla, że w przeciwieństwie do wzoru wyrażającego się w rzeczywistych działaniach ludzi, model ma charakter symboliczny, jest „słownym, obrazowym lub jakimkolwiek symbolicznym przedstawieniem ludzkiego zachowania (insty- 
tucji, osobowości), mogącym służyć za przykład i przedmiot odniesienia ocen i skonstruowanym dla praktycznych celów społecznych" (Kłoskowska 1959: 50). Modele społeczne pełnią funkcje wychowawcze i propagandowe, choć funkcje te nie zawsze są zamierzone i uświadamiane przez „producentów kultury” (tamże: 52). Jak ujmuje to J. Szczepański, model dotyczy ,[... [ pewnego pożądanego stanu rzeczy, o którym wiadomo, że w rzeczywistości nie występuje, a który służy do oceny zjawisk i stanów rzeczy zachodzących rzeczywiście. Jest on jakby wcieleniem pewnych wartości. Słowem, model jest czymś, co się naśladuje" (Szczepański 1970: 102). Takiemu rozumieniu modelu kulturowego odpowiada pojęcie „wzoru idealnego”, wprowadzone przez R. Lintona (Linton 2000: 69). A zatem modele należą do porządku aksjonormatywnego, ,kultury idealnej”, przyjmując niekiedy wprost formę normatywnych sformułowań, podczas gdy wzory dotyczą „kultury realnej”, rzeczywistych sposobów postępowania ludzi. Antonina Kłoskowska podkreśla dynamiczny charakter wzorów kulturowych, zmieniających się w odpowiedzi na zmiany rzeczywistości społecznej. Zwraca także uwagę, że nie są one jednolite i w tej samej dziedzinie zachowania współwystępować mogą różne, konkurencyjne wobec siebie wzory (Kłoskowska 1959: 48). Jak stwierdza, „nowe wzory instytucjonalne mogą wyłaniać się w momencie, gdy dawne nie utraciły jeszcze mocy" (tamże). Obok wzorów ustalonych funkcjonować mogą więc „wzory wyłaniające się, zaczątkowe”, które „zyskują dopiero grunt w praktyce społecznej”, dotycząc początkowo jedynie części społeczeństwa (tamże).

Jeżeli chodzi o modele społeczne, A. Kłoskowska wskazuje, że możemy mieć do czynienia z modelami odpowiadającymi zarówno ustalonym, jak i zaczątkowym, nowatorskim wzorom zachowania. Modele o charakterze konserwatywnym podtrzymują i sankcjonują utrwalone schematy postępowania, natomiast modele o charakterze nowatorskim ,rozprzestrzeniają i utwierdzają nowe, gruntujące się dopiero sposoby zachowania" (Kłoskowska 1959: 51). W społeczeństwie mogą występować także „czyste” modele (ideały) nieposiadające odpowiedników w aktualnych, faktycznych zachowaniach społecznych, „wyrażające aspiracje i pragnienia raczej aniżeli aktualną praktykę społeczną" (tamże). Odwołują się one jednak do uznanych, przynajmniej w określonych kręgach, wartości i norm społecznych. Jak zaznacza autorka, „czyste” modele, podobnie jak modele nowatorskie odgrywają istotną rolę w procesie wprowadzania i utrwalania nowych wzorów społecznych (tamże: 52).

Antonina Kłoskowska traktuje modele i wzory jako dwie płaszczyzny badań zachowania społecznego - faktyczne zachowania oraz ,towarzyszące im refleksje, normy i oceny" (Kłoskowska 1962: 35, 37). W swych opracowaniach wiele miejsca poświęca kwestii możliwości i sposobów ich badania. Gdy celem jest zbadanie modeli społecznych, analizie poddawane są ,słowne, obrazowe lub jakiekolwiek symboliczne przedstawienia ludzkiego zachowania", na przykład modele popularyzowane w przekazach kultury masowej (Kłoskowska 1959: 50). Badanie wzorów społecznych jest natomiast badaniem konkretnych rzeczywistych 
zachowań ludzi, prawidłowości, reguł tych zachowań (chociaż najczęściej badamy relacje aktorów społecznych o ich zachowaniach, nie same zachowania). Autorka zwraca uwagę, że badacze posługujący się techniką wywiadu często traktują deklaracje badanych co do norm postępowania obowiązujących w danej kulturze jako przedstawienia wzorów faktycznych zachowań. „Poważnym źródłem błędów powstających przy interpretacji danych ankietowych jest fakt, że wówczas gdy socjolog oczekuje od osób badanych przedstawienia wzorów ich zachowania lub przynajmniej dostarczenia materiału do poznania tych wzorów, badani w odpowiedzi na postawione pytania dokonują często prezentacji uznawanych we własnym środowisku norm i wartości. Inaczej mówiąc, miast wzoru przedstawiają obowiązujący w danym społecznym kręgu model zachowania i postaw" (Kłoskowska 1962: 44). A zatem, jeżeli mamy do czynienia z wynikami badań społecznych dotyczących rzeczywistych zachowań ludzi, to analizie podlegają wzory społeczne. Jeżeli są to dywagacje, rozważania odnoszące się do obowiązujących w danym społeczeństwie reguł „w ogóle”, czy powszechnych opinii na jakiś temat, to dotyczą one nie wzorów, a modeli społecznych.

A. Kłoskowska wyróżnia modele propagandowe i środowiskowe. Te pierwsze to modele „oficjalne”, „stanowiące wytwór wyspecjalizowanych agend społecznych”, „przyjęte w skali szerszego społeczeństwa” (Kłoskowska 1962: 45, 47). „Do tej kategorii należą właśnie modele popularyzowane w literaturze, w prasie i innych środkach komunikacji masowej, formułowane przez osoby i grupy pełniące funkcje wychowawcze i propagandowe, przez nauczycieli, kaznodziei, moralistów, propagatorów, polityków i działaczy społecznych" (tamże: 45). Natomiast modele środowiskowe są ,własnym produktem grup i środowisk, do których postępowania bezpośrednio się odnoszą", wskazują na dominujące i uznane w danej grupie właściwe sposoby postępowania (tamże: 45). Można je określić, za C. Lévi-Straussem, jako modele „domowego wyrobu” (tamże: 40). Autorka zwraca uwagę, że modele propagandowe i środowiskowe „na ogół wpływają na siebie wzajem, ale stosunek ich treści może się wahać od identyczności do całkowitej przeciwstawności”, a zatem warto badać relacje między nimi (tamże: 45, 51).

Jak zaznacza A. Kłoskowska, analiza społecznych modeli i wzorów powinna obejmować także kwestię wzajemnego ich stosunku i powiązania, ustalenia, na ile są one zgodne, na ile rozbieżne (Kłoskowska 1960: 123). Najwartościowsze jest zatem zajmowanie się zarówno modelami, jak i wzorami, co uwzględnione zostało w niniejszej pracy.

\subsection{Rola społeczna w wybranych teoriach socjologicznych}

Jeżeli wzory i modele określają zachowania jednostek, to dotyczą zachowań w rolach pełnionych przez nie w społeczeństwie. Pojęcie „rola społeczna” pojawia się w socjologii w wielu koncepcjach teoretycznych. W licznych opraco- 
waniach dokonujących przeglądu różnych sposobów rozumienia roli społecznej (m.in. Biddle 1992; Bieliajew, Szalin 1978; Szmatka 1973, 1974, 2000; Turner J.H. 1985, 2004; Znaniecki 1986) autorzy zestawiają najczęściej ujęcie biorące za punkt odniesienia $\mathrm{w}$ analizie roli społecznej strukturę społeczną z perspektywą zorientowaną na jednostkę i jej osobowość (np. Białyszewski 1967; Kawka 1998; Hałas 2006a). Odwołując się do metafory teatralnej, często przywoływanej w omawianiu problematyki roli społecznej, można powiedzieć, że pierwsze podejście - określane jako statyczne oraz normatywne - koncentruje się na scenariuszu roli i całego społecznego spektaklu. W drugim, dynamicznym, behawioralnym podejściu przedmiotem zainteresowania jest natomiast proces podejmowania roli oraz interakcje między aktorami na społecznej scenie. U podstaw tych dwóch odmiennych ujęć leży inna wizja społeczeństwa i jednostki oraz ich wzajemnych relacji (perspektywa strukturalnego funkcjonalizmu i normatywna koncepcja roli oraz perspektywa interakcjonizmu symbolicznego) (Lacek 2004: 274; Piotrowski 1981). Także tutaj odwołamy się do porównania obu sposobów podejścia, by w kolejnych podrozdziałach wskazać przyjęty w pracy sposób rozumienia świata społecznego i roli społecznej.

Jak już wspomniano, przedmiotem zainteresowania części teoretyków są przede wszystkim reguły określające „właściwe” zachowania jednostek pełniących role społeczne, czyli „scenariusz roli”. Mówimy tu o normatywnym ujęciu roli społecznej (Białyszewski 1967: 178; Ehrlich 1994; Szmatka 2000: 322). „Orientacja normatywna opiera się na takim modelu ładu społecznego, w którym regularność zachowań tłumaczy się istnieniem norm i wzorów determinujących zachowanie lub działanie społeczne [...]" (Piotrowski 1981: 28). Aktor społeczny jawi się tu jako marionetka odgrywająca rolę w oczekiwany społecznie sposób pod groźbą negatywnych sankcji. Jak stwierdza Talcott Parsons, ,[...] z punktu widzenia systemu społecznego rola jest elementem ogólnego wzoru wyznaczającego działanie jednostek, które się na ten system składają. [...] Jest to sprawa celów i norm. Z punktu widzenia aktora jego rolę określają oczekiwania normatywne członków grupy, narzucone przez tradycje społeczne. [...] Postępowanie zgodnie z nimi lub od nich odbiegające powoduje dla aktora konsekwencje w postaci uznania i nagrody lub potępienia i kary" (Parsons 1972: 306-307). Jak wiadomo, w swojej teorii działania społecznego T. Parsons starał się uwzględnić woluntaryzm jednostki, fakt, że aktorzy społeczni mają wolną wolę i to oni podejmują decyzję o wyborze takiego a nie innego sposobu zachowania w określonej sytuacji (Szacki 2005: 818). Jednak, jak zauważa Zygmunt Bauman, w miarę rozwijania teorii T. Parsons położył nacisk nie na działanie jednostki i jej motywy, ale na system społeczny, „który z góry zakreśla ramy wyborów i w gruncie rzeczy decyduje o tym, jak działania będą zorientowane" (Bauman 1999a: 25).

Ralf Dahrendorf wskazuje na trzy rodzaje oczekiwań wpisanych w role społeczne: bezwzględne nakazy (oczekiwania typu „musi”), powinności (oczekiwania typu „będzie”) oraz oczekiwania typu „może” (Dahrendorf 2005a: 313-314). 
Zwraca uwagę na pewien margines swobody w ramach pełnionej roli - „zakres, w którym jednostka może się zachowywać w dowolny, wybrany przez siebie sposób”, zaznaczając jednak, iż „te obszary wolnych wyborów są niewielkie w porównaniu z olbrzymimi obszarami skrępowania związanego z usankcjonowanymi oczekiwaniami wobec roli” (tamże: 315). Nakazy roli zostają zinternalizowane przez jednostkę w procesie socjalizacji, a konformizm wobec tych normatywnych oczekiwań zapewnia stabilność i harmonijne funkcjonowanie społeczeństwa.

Rozważania na temat „przepisów ról” nałożonych na aktorów społecznych nie ograniczają się do scenariusza pojedynczej roli, ale całego „spektaklu społecznego”. Jeżeli potraktujemy ,społeczeństwo jako dramat” (Berger 2004), „gigantyczną sztukę" (Dahrendorf 2005a), to scenariusz życia społecznego obejmowałby podział na role między jednostki, z których każda ma określoną ,partię” do zagrania. W perspektywie strukturalno-funkcjonalnej społeczeństwo jest widziane właśnie jako system, w ramach którego jednostki zajmują określone pozycje społeczne i realizują przypisane tym pozycjom zachowania. Według R. Dahrendorfa, ,[...] obejmując pozycję społeczną, jednostka staje się postacią $\mathrm{w}$ dramacie napisanym przez społeczeństwo, w którym żyje. Wraz z objęciem każdej pozycji społeczeństwo wręcza jednostce rolę do zagrania" (Dahrendorf 2005b: 311). Powiązanie pojęcia roli społecznej z pojęciem statusu (pozycji społecznej) pojawiło się po raz pierwszy w pracach antropologa Ralpha Lintona (Białyszewski 1967: 178). Definiował on rolę jako „całościową sumę wzorów kulturowych wiążących się z określonym statusem”, obejmującą ,postawy, wartości i zachowania, które społeczeństwo przypisuje każdej osobie posiadającej dany status" (Linton 2000: 98).

Taki sposób rozumienia roli społecznej mieści się w ujęciu makrostrukturalnym, w którym ,role społeczne są pewnymi elementami systemów społecznych funkcjonalnymi w stosunku do nich" (Szmatka 1973: 148). Role traktuje się jako element pośredniczący między jednostką a społeczeństwem, „ogniwo łączące aktora jako byt «psychologiczny» ze strukturą społeczną" (Parsons 1972: 306). Punktem wyjścia jest tu nie jednostka, ale system społeczny determinujący określone zachowania człowieka, narzucając mu role i kontrolując właściwy sposób ich wypełniania. Podsumowując to makrostrukturalne, strukturalno-funkcjonalne ujęcie roli społecznej, warto odwołać się do rozważań R. Dahrendorfa, który wskazuje trzy właściwości charakteryzujące kategorię roli społecznej. „1) Role społeczne, podobnie jak pozycje, są quasi-obiektywnymi zestawami nakazów zachowania zasadniczo niezależnymi od jednostki. 2) Ich indywidualna istota jest definiowana i redefiniowana nie przez jednostkę, lecz przez społeczeństwo. 3) Oczekiwania zachowań związanych z rolami są wiążące dla jednostki, co znaczy, że nie może ona ich zignorować lub odrzucić bez własnego uszczerbku" (Dahrendorf 2005a: 312). Jednostka jest „nosicielem ról społecznych” - „,społecznie narzuconych właściwości i sposobów działania" (tamże: 307, 309). Role są traktowane więc jako coś stałego, zewnętrznego, ,nałożonego" na jednostki - biernych aktorów życia społecznego - które uczestnicząc w społeczeństwie, wchodzą w przeznaczone im role. 
Jak stwierdzają E.W. Bieliajew i D.N. Szalin, część teoretyków roli koncentruje się na innym aspekcie analogii świata teatru i świata społecznego - nie na „wyznaczoności, określoności, przypisaniu zachowania człowieka odpowiednio do miejsca, które zajmuje w społeczeństwie”, ale na „twórczym pierwiastku improwizacji właściwym aktorowi na scenie i człowiekowi w życiu” (Bieliajew, Szalin 1978: 104, 105). Przedmiotem zainteresowania jest już nie system społeczny, ale jednostka w interakcjach z innymi uczestnikami społeczeństwa. Stawia się tu pytanie o zachowania i działania ludzi w określonej sytuacji, a zatem nie o normatywny, a behawioralny aspekt roli, nie o oczekiwane, ale aktualne, rzeczywiste zachowanie jednostki pełniącej daną rolę oraz warunkujące je czynniki. Taka perspektywa odrzuca wizję jednostki działającej według danego jej „kulturowego przepisu" i otwiera możliwość badania twórczych, improwizowanych, innowacyjnych działań w realizowanej roli (Hałas 2006a: 224, 227, 228). Aktorzy społeczni są traktowani jako świadomi kreatorzy ról, którzy grając „,w teatrze życia codziennego", uwzględniają oczekiwania i możliwe reakcje współpartnerów przedstawienia oraz publiczności i kontrolują wywierane przez siebie wrażenia (Goffman 1981). Rola społeczna jest postrzegana jako coś zmiennego, negocjowanego w procesach interakcji (Turner R.H. 1985: 24, 26). Zwraca się uwagę na sytuacyjny charakter odgrywania roli - takie a nie inne jej wykonanie (występ) zależy od konkretnej sytuacji. Nie oznacza to jednak, że jest ono przypadkowe, wręcz przeciwnie - uporządkowane i przebiegające według pewnych, możliwych do określenia prawidłowości (Hałas 2006a: 232). Interakcjoniści nie kwestionują istnienia normatywnego wymiaru roli, postrzegają go jednak nie jako jedyny wyznacznik ludzkiego zachowania w danej sytuacji, wobec innych ludzi, lecz jako pewien zasób, z jakiego korzysta jednostka, konstruując swoje postępowanie (tamże: 224). Wiedza na temat ról społecznych oznacza bowiem wiedzę ,gdzie się coś wydarzy, co się wydarzy i kto uczestniczy w wydarzeniu” oraz „o wzajemnych relacjach działających w różnych sytuacjach" (tamże).

Wizja aktora społecznego jako aktywnej, upodmiotowionej, twórczej jednostki najpełniej znajduje wyraz w koncepcji Ralpha H. Turnera, dla którego przyjmowanie roli jest jednocześnie jej tworzeniem (Turner R.H. 1962: 22; Łoś 1985: 126; Turner J.H. 2004: 447). Teoretyk ten jest autorem syntetycznego ujęcia roli społecznej, uwzględniającego słabości i wady wcześniejszych koncepcji, koncentrujących się głównie na normatywnych elementach roli (Turner R. H. 1985). Istotne są dla niego pytania m.in. o zmienność ról oraz kreatywność jednostki w pełnieniu roli, których nie stawiają autorzy strukturalnych teorii (tamże: 26). W swoim ujęciu rozwija on myśl G.H. Meada, podkreślając interakcyjny charakter roli społecznej i dokonując analizy procesu przyjmowania i tworzenia roli (role taking, role making) (Turner R.H. 1962; Mead 1975). Według R. Turnera aktorzy społeczni znajdując się w określonej sytuacji, wyobrażają sobie, co ich interakcyjni partnerzy myślą, że oni najprawdopodobniej zrobią (Hałas 2006a: 234). Konkretne 
zachowanie partnera jest definiowane i interpretowane przez odniesienie do innych zachowań składających się na spójną, sensowną, znaczącą całość, przy czym ,to samo zachowanie może być wskazówką różnych ról w różnych okolicznościach" (tamże: 235, 236). Rola jest tu postrzegana nie jako istniejący już, normatywny scenariusz, z którym zgodne jest lub nie określone zachowanie jednostki, ale definiowany w trakcie procesu interakcji zespół zachowań, powiązanych i spójnych ze sobą, odpowiadających intencji działającego (Turner R.H. 1962: 22; Hałas 2006a: 236; Turner J.H. 2004: 447). ,Ludzie próbują ułożyć zachowanie swych partnerów w koherentne całości i czyniąc to, mogą nadać sens działaniom innych, przewidywać reakcje innych i przystosowywać swe własne reakcje do reakcji innych. [...]. Podejmują próby szacowania spójności działań innych, aby rozpoznać leżącą u ich podstaw rolę, która jest odgrywana" (Turner J.H. 2004: 447). Niezbędny do tego jest pewien zasób ,potocznej”, „podręcznej” wiedzy, opartej na doświadczeniu jednostki, zawierającej ,przekonania, oczekiwania i wymogi zarówno wobec siebie, jak i innych uczestników interakcji” oraz ,procedury działania”, umożliwiającej rozumienie sytuacji i zachowań innych oraz odpowiednie reagowanie na nie (Łacek 2004: 284). Ralph Turner (1962: 29-30) wskazuje na dwa sposoby uprawomocnienia przyjętej przez jednostkę roli uczestnika interakcji, traktowanej przez nią jako rzeczywista (jak gdyby istniała naprawdę): uprawomocnienie wewnętrzne (wynikające z samej interakcji) oraz zewnętrzne wobec interakcji, pochodzące od „uogólnionego innego”, „trzeciej strony interakcji - osobowej lub nieosobowej (np. wartości społeczne)" (Hałas 2006a: 237). Uprawomocnienie zewnętrzne dotyczyć będzie na przykład ról mających w świadomości społecznej określoną nazwę (,Jeśli wzór zachowania może być nazwany, uzyskuje on tym samym obiektywność”) (tamże). Mamy tu zatem odwołanie do czegoś pozasytuacyjnego, ,kulturowej matrycy, uprzedniej wobec interakcji”, która jest punktem odniesienia dla uzgadniania znaczenia i spójności zachowań składających się na role uczestników (tamże: 238). Co do wewnętrznego, płynącego z samej interakcji uprawomocnienia przyjętej roli, polega ono na interpretacji zachowania partnera i skutecznym dostosowaniu do niego własnego postępowania (tamże: 239). Przy czym nie istnieją przepisy na właściwe, odpowiednie, dopasowane do siebie „,zestawy zachowań” partnerów, z których jednostka mogłaby skorzystać, nie istnieją bowiem stałe, ustalone wzory ról społecznych, jedynie pewne niejasne i niekompletne, stale modyfikowane idealne koncepcje ról. Jednostka każdorazowo definiując zachowanie drugiej osoby przez odniesienie go do owej idealnej koncepcji roli, spójnej całości zachowań, musi zdecydować jak sama zagra, w jaką rolę, komplementarną wobec roli partnera, sama wejdzie, musi swoją rolę stworzyć.

Podsumowując, interakcyjne, dynamiczne ujęcie roli społecznej opiera się na założeniu, że to jednostki są twórcami ról społecznych i tworzą je, interpretując, uzgadniając i dostosowując wzajemnie swoje zachowania w procesach interakcji. Rzeczywistość społeczna jawi się tu jako płynna, zmienna, niedookreślona, której dopiero jednostki nadają określone znaczenia. Daje się w niej dostrzec powtarzal- 
ne wzory zachowań, mają one jednak charakter sytuacyjny, nie stały i ,gotowy” do zastosowania w danej sytuacji. Podobnie role społeczne „są stale konstruowane i odnawiane w odniesieniu do innych ról" (Hałas 2006a: 248).

Przedstawione dwa odmienne, odwołujące się do różnych koncepcji świata społecznego, ujęcia roli społecznej zostały tu z konieczności zaprezentowane w sposób uproszczony, bez uwzględnienia wewnętrznego zróżnicowania omawianych perspektyw ${ }^{1}$. Zwrócono tu przede wszystkim uwagę na różnice między nimi w postrzeganiu roli (ujęcie statyczne, strukturalne, normatywne versus ujęcie dynamiczne, interakcyjne, behawioralne) oraz udziału jednostki w kreowaniu roli (bierny odtwórca roli versus twórca roli). Owo porównanie jest punktem wyjścia dla rozważań poświęconych przyjętej w pracy koncepcji jednostki i społeczeństwa (podrozdział 1.3) oraz spójnej z nią koncepcji roli społecznej (podrozdział 1.4). Tym bardziej że przyjęta perspektywa łączy przedstawione opozycyjne podejścia.

\subsection{Podmiotowość jednostek w teorii strukturacji Anthony'ego Giddensa}

Przyjęta w niniejszej pracy teoria strukturacji Anthony'ego Giddensa pozwala na pogodzenie konkurencyjnych, przedstawionych wcześniej koncepcji świata społecznego, jednostki i wreszcie roli społecznej. Zdaniem J.H. Turnera teoria ta jest ,jednym z najbardziej twórczych osiągnięć teoretycznych drugiej połowy XX w." (Turner J.H. 2004: 571). A. Giddens stworzył ją, poddając krytyce dotychczasowy dorobek teoretyczny socjologii oraz odwołując się do różnych koncepcji wypracowanych na gruncie filozofii. Jak stwierdza J. Szacki, „ [...] teorię Giddensa cechuje dążenie do wielkiej syntezy. Giddens stara się nie pominąć niczego, cokolwiek ważnego wydarzyło się w naukach społecznych i filozofii" (Szacki 2005: 882). Z szerokiego nurtu socjologii interpretatywnej autor przejmuje m.in. koncepcję jednostki jako kompetentnego i twórczego podmiotu, zainteresowanie działaniem znaczącym, komunikacją i językiem, a także postrzeganie rozumienia nie tylko jako techniki stosowanej w badaniach społeczeństwa, ale jako podstawowego elementu wszystkich interakcji społecznych (Giddens 2001a). Zarzuca jednak koncepcjom wypracowanym $\mathrm{w}$ ramach socjologii interpretatywnej, że „są mocne w analizach działania, ale słabe w analizowaniu struktury”, ignorują zagadnienia władzy i konfliktu, wreszcie że pozostawiają bez odpowiedzi pytania o historię i zmianę społeczną (Giddens 2001a: 15, 86). A. Giddens poddaje także krytyce funkcjonalizm, zwracając uwagę, że mimo podjęcia przez T. Parsonsa problematyki działania jest ono pozbawione woluntaryzmu, postrzegane jako

${ }^{1}$ Nie wszystkie koncepcje w ramach ujęcia strukturalnego są skrajnie normatywnymi ujęciami roli społecznej, podobnie jak nie wszystkie koncepcje w ramach ujęcia interakcyjnego są podejściami skrajnie sytuacyjnymi. 
efekt internalizacji wartości (tamże: 42). „W Parsonsowskim «układzie odniesienia działania» nie ma działania, są tylko zachowania, uruchamiane przez potrzeby - dyspozycje lub oczekiwania roli. [...] aktorzy jedynie odgrywają scenariusze, które zostały dla nich wcześniej napisane" (tamże: 37). Innymi błędami w ramach teorii funkcjonalnej są, według A. Giddensa, brak traktowania życia społecznego jako wytworu, efektu działań jednostek, uczynienie norm i wartości podstawowymi wyznacznikami działań społecznych i nieuwzględnianie negocjacyjnego charakteru norm oraz zepchnięcie zagadnienia władzy na dalszy plan (tamże: 42-43). Inspirująca dla autora była teoria Karola Marksa, z której zaczerpnął on ideę wytwarzania i reprodukowania życia społecznego (tamże: 147-150, 180).

Anthony Giddens tworząc własną perspektywę teoretyczną, świadomy słabości i niedostatków dotychczasowych koncepcji socjologicznych, skupionych albo na analizach jednostkowych działań, albo na analizach struktury, odrzuca ,imperializm podmiotu" teorii koncentrujących się na subiektywnych doświadczeniach jednostek oraz ,imperializm przedmiotu” stanowisk teoretycznych przyjmujących istnienie zewnętrznych wobec jednostek struktur społecznych (Giddens 2001a: 15; 2003: 40; Sztompka 1998: 238). Autor przełamując ten dualizm orientacji socjologicznych, odrzucając skrajny subiektywizm i skrajny obiektywizm, przełamuje zarazem dualizm jednostka - społeczeństwo, wolność - przymus (Giddens 2001a: 15; Szacki 2005: 886). Zaznacza, że w jego teorii strukturacji punktem wyjścia i przedmiotem analizy „nie jest ani doświadczenie indywidualnego aktora, ani jakakolwiek "całość społeczna», lecz uporządkowane w czasie i przestrzeni praktyki społeczne [podkr. K.D.-G.]" (Giddens 2003: 40). Zdaniem Z. Baumana, Giddens jest „orędownikiem koncepcji teorii społeczeństwa jako teorii działania społecznego” (Bauman 1999a: 27). „Dziedzinę przedmiotową socjologii” stanowi, według Giddensa, ,wytwarzanie i reprodukowanie społeczeństwa" (Giddens 2001a: 224).

Trzeba tu zaznaczyć, że A. Giddens nie jest ani pierwszym, ani jedynym teoretykiem poszukującym ,trzeciej drogi”2 w socjologii, jak określa Agnieszka Kołodziej-Durnaś „,stanowisko łączące (i przekraczające ich ograniczenia) podejście strukturalistyczno-funkcjonalistyczne i tzw. podejścia interpretatywne" (Kołodziej-Durnaś 2004: 7, 9). Autorka zauważa, że wśród klasyków próbę przezwyciężenia dualizmów w socjologii podejmowali m.in. Karol Marks oraz Florian Znaniecki. Wskazuje także na podobieństwa między teorią strukturacji a podejściem Margaret Archer, Pierre'a Bourdieu czy Piotra Sztompki. Piotr Sztompka z kolei omawia koncepcję Giddensa obok własnej teorii podmiotowości oraz

${ }^{2}$ A. Kołodziej-Durnaś nawiązuje tu do książki A. Giddensa Trzecia droga. Odnowa socjaldemokracji (wyd. pol. 1999), podważającej tradycyjny podział na lewicę i prawicę w polityce - „Anthony Giddens pisał dużo o trzeciej drodze w polityce (tzw. nowej lewicy); być może teoria strukturacji zostanie kiedyś określona jako przykład wyznaczania takiej drogi w naukach społecznych" (Kołodziej-Durnaś 2004: 9). 
teorii autorstwa takich socjologów, jak m.in. Walter Buckley, Amitai Etzioni, Alain Tourraine, Michael Crozier, Tom Burns, czy Margaret Archer (Sztompka 2002a: 237; Sztompka 2005). Według niego nowoczesne teorie podmiotowości, traktujące ją jako właściwość wszystkich jednostek (a nie jakichś sił ponadnaturalnych, pozaludzkich, społeczeństwa jako całości, czy jednostek wybitnych lub pełniących określone role społeczne) to jeden z najważniejszych kierunków teoretycznych końca XX w. (Sztompka 2002a: 236; 2005:183-185). P. Sztompka mówi o nowym ruchu teoretycznym w ramach socjologii zmian społecznych. U podstaw wszystkich tych teorii leżą następujące założenia: a) Rzeczywistość społeczna ma procesualny, zmienny charakter; b) Źródłem tej zmienności jest podmiotowe działanie jednostek i zbiorowości społecznych; c) działania są podejmowane w ramach istniejących struktur społecznych, które są w toku działania przekształcane; d) zarówno struktury, jak i podmioty mają dwoisty charakter - są zarazem determinujące i determinowane (Sztompka 2002a: 237).

O wykorzystaniu teorii strukturacji A. Giddensa w niniejszej pracy, podejmującej problematykę płciowych i rodzicielskich ról społecznych realizowanych przez młodych wykształconych Polaków, zadecydowało kilka względów. Po pierwsze, mimo wspomnianych wspólnych założeń, wymienione wyżej teorie koncentrują się na różnych aspektach życia społecznego. Na przykład porównanie teorii Giddensa i teorii Pierre'a Bourdieu pokazuje, że ,francuski socjolog środek ciężkości funkcjonowania rzeczywistości społecznej przesuwa jednak ku strukturom społecznym”, podczas gdy twórca teorii strukturacji skupia się na ,autonomii działającej jednostki” (Kołodziej-Durnaś 2004: 112). Teoria Giddensa, odchodząc od ,imperializmu podmiotu”, koncentruje się na jednostce jako twórcy społeczeństwa, działającej jednak w określonych społecznie ramach umiejscowionych w danym czasie i przestrzeni. Taki sposób widzenia aktora społecznego i społecznego świata pozwala na analizę problematyki ról społecznych jako określonych praktyk społecznych odtwarzanych i zarazem tworzonych przez jednostki. Jak stwierdza Z. Bauman, Giddens punktem wyjścia swoich analiz czyni aktora, ,a nie społecznie wytworzoną już strukturę społeczeństwa” (Bauman 1999a: 29). Teoria ta nie pozwala traktować ról społecznych jako gotowych przepisów na działanie, a jednocześnie pozwala na pytanie o przyczynę trwałości pewnych wzorów zachowań. Ponieważ Giddens przedmiotem zainteresowania socjologii czyni „praktyki społeczne”, podejście to umożliwia analizę codziennych działań ludzi, jak tych związanych z byciem kobietą/mężczyzną oraz matką/ ojcem i zrozumienie, dlaczego jednostki postępują w taki a nie inny sposób. Po drugie, A. Giddens należy do wciąż niezbyt licznego grona socjologów uwzględniających płeć kulturową (gender) w rozważaniach i badaniach socjologicznych

3 Teorie te często są obok siebie omawiane, czy wręcz porównywane ze sobą (Szacki 2005; Kołodziej-Durnaś 2004; Turowski 2005). Chociaż na przykład P. Sztompka nie wymienia P. Bourdieu wśród twórców nowoczesnych teorii podmiotowości (Sztompka 2005). 
i podkreślających znaczenie genderowej perspektywy w analizie życia społecznego. Problematykę tę wprowadza w swoim podręczniku socjologii, uwzględniając płeć w omawianiu różnych zjawisk społecznych, a także, mniej lub bardziej wyraźnie, w pracach poświęconych współczesnemu społeczeństwu, tożsamości jednostki oraz związkom intymnym (Giddens 2001b; 2004; 2006; 2008; 2009). Po trzecie, jak zauważa A. Kołodziej-Durnaś, w porównaniu z pracami innych teoretyków, podejmujących zagadnienie relacji między jednostką i strukturą oraz próbujących przezwyciężyć wspominane dychotomie w socjologii, „teoria strukturacji jest reprezentatywnym i najbardziej kompletnym dziełem tej nowej orientacji” (Kołodziej-Durnaś 2004: 135). Ponadto A. Giddens odwołuje się do swojej teorii, podejmując analizę nowoczesnego społeczeństwa w różnych jego aspektach i na różnych poziomach (porządek makrospołeczny, globalny i zjawiska mikrospołeczne oraz indywidualne, jak ,przemiany intymności” czy tożsamość jednostki), co sprawia, że teoria ta znajduje zastosowanie, jest ,żywa” i przydatna do wyjaśniania różnych zjawisk społecznych. Łatwo również zauważyć, że A. Giddens i jego teoria obecni są w kluczowych podręcznikach i opracowaniach prezentujących dorobek socjologii, w których podkreśla się znaczenie teorii strukturacji we współczesnej myśli socjologicznej (Turner J.H. 2004; Szacki 2005). Nie bez znaczenia wreszcie jest także dostępność i popularność prac autora, przetłumaczonych w dużej części na język polski.

Jak stwierdza J.H. Turner, ,[...] ponieważ Giddens nie wierzy w istnienie abstrakcyjnych praw działania społecznego, interakcji i organizacji, jego «teoria strukturacji» nie jest szeregiem twierdzeń. Zamiast tego, zgodnie z tezami przeprowadzonej przezeń krytyki nauki, «teoria» Giddensa pozostaje wiązką pojęć uwrażliwiających powiązanych ze sobą fragmentarycznie" (Turner J.H. 2004: 572). Przedstawione teraz zostaną te pojęcia i elementy koncepcji Giddensa, które mogą być pomocne w lepszym zrozumieniu i analizie podjętej problematyki. Następnie zostaną zaprezentowane najważniejsze, według autora, cechy nowoczesnego społeczeństwa, do którego odnoszą się rozważania dotyczące ról płciowych i rodzicielskich.

Wspomniane odrzucenie dualizmu jednostka - społeczeństwo w teorii strukturacji wymagało przeformułowania, dekonstrukcji obu tych pojęć (Giddens 2001a: 16). Przede wszystkim konieczne było nadanie nowego znaczenia pojęciu struktury, pojmowanej do tej pory, przede wszystkim na gruncie funkcjonalizmu, jako coś zastanego, zewnętrznego, niezależnego wobec jednostki, ograniczającego jej swobodę działania (Giddens 2003: 26, 55). A. Giddens wychodzi z założenia, że ,[...] każda forma ograniczenia jest zarazem formą stwarzania możliwości. Każda jednocześnie czegoś zakazuje, a zarazem otwiera jakieś możliwości” (tamże: 219). Według niego „struktury nie można konceptualizować jako domeny przymusu, wywieranego na działanie podmiotowe, ale winna ona być pojmowana jako czynnik tworzący możliwość takiego działania" (Giddens 2001a: 226). Autor podkreśla „podwójną zależność” jednostek i spo- 
łeczeństwa - „tworzymy społeczeństwo, będąc jednocześnie przez nie stwarzani” (Giddens 1998: 21-22); „nasze działania zarówno strukturują - kształtują - otaczającą nas rzeczywistość społeczną, jak i same są przez tę rzeczywistość ustrukturowane" (Giddens 2004: 29). To pogodzenie opozycji między subiektywizmem i obiektywizmem, ,spójne ujęcie ludzkiego działania i struktury” (Giddens 2003: 19), jest według autora możliwe dzięki wprowadzeniu kategorii „dualności struktury” - traktowaniu struktury zarówno jako warunku, jak i jako rezultatu interakcji, powtarzanych praktyk społecznych, rutynowych działań jednostek (Giddens 2001a: 222). „Badanie strukturacji praktyk społecznych oznacza poszukiwanie wyjaśnienia, jak dochodzi do tego, iż struktura jest konstytuowana przez działanie oraz odwrotnie - jak działanie jest tworzone pod wpływem struktury" (Giddens 2001a: 226).

A. Giddens precyzuje pojęcie struktury, definiując ją jako „reguły i zasoby uwikłane w proces społecznej reprodukcji” (Giddens 2003: 30). Reguły określa jako techniki i procedury stosowane przez aktorów w produkowaniu i reprodukowaniu praktyk społecznych - rutynowych, powtarzalnych, usytuowanych w czasie i przestrzeni działań i interakcji (tamże: 60). Zwraca uwagę na dwa aspekty reguł: kod znaczeniowy oraz elementy normatywne - ,reguły z jednej strony konstytuują znaczenia, z drugiej zaś sankcjonują sposoby społecznych zachowań" (tamże: 57). Reguły mogą być: intensywne lub płytkie w zależności od wpływu na codzienne życie społeczne (regułami intensywnymi są na przykład reguły językowe, stale przywoływane przez aktorów w codziennej działalności), milczące lub dyskursywne (wypowiedziane, wyrażone słownie), nieformalne lub sformalizowane, wreszcie słabo lub silnie usankcjonowane (skodyfikowane normy prawne są przykładem reguł dyskursywnych, sformalizowanych, silnie usankcjonowanych oraz, zdaniem Giddensa, raczej płytkich) (Giddens 2003: 61-62). Według Giddensa aktorzy w swoich rutynowych działaniach, wytwarzaniu i odtwarzaniu praktyk społecznych kierują się milczącymi, ukrytymi regułami, po prostu ,wiedzą, jak postępować". Autor traktuje skodyfikowane, wyrażone słownie reguły nie tyle jako reguły, ile jako ich interpretacje - „dyskursywne sformułowanie reguły jest już jej interpretacją i [...] samo przez się wpłynąć może na jej stosowanie" (tamże: 60, 62).

Struktura obok reguł obejmuje także dwa typy zasobów: materialne i niematerialne. Te pierwsze - „zasoby alokacyjne” - wiążą się z kontrolą nad materialnymi produktami i przyrodą, drugie - „zasoby autorytetu” - mają swe źródło w ,zdolnościach panowania nad ludzką działalnością, dominacji jednych aktorów nad drugimi” (Giddens 2003: 427). Przy czym „zasoby autorytetu” nie są tożsame z władzą, którą Giddens definiuje jako zdolność wywierania skutku, interwencji, wpływania na określony proces czy stan rzeczy lub powstrzymania tego wpływu (tamże: 53). Jako „władza wytwórcza” - „zdolność przekształcania”, zdolność dokonywania zmian stanowi cechę, właściwość podmiotu działającego i jest wpisana w każde działanie jednostki (tamże). 
„Reguły i zasoby, z których korzysta się w procesie produkcji i reprodukcji działań społecznych, są zarazem środkami reprodukcji systemu (dualność struktury)" (Giddens 2003: 58). Autor zaznacza, że pojęcia reprodukcji nie powinno odnosić się ani do zagadnienia stabilności społecznej, ani zmiany społecznej - statyki i dynamiki społecznej, wręcz przeciwnie, służy ono przełamaniu tego podziału (Giddens 2001a: 182). „Każdy czyn, który przyczynia się do reprodukowania struktury, jest zarazem czynem wytwarzającym, twórczym przedsięwzięciem, i jako taki może inicjować zmianę zmieniając strukturę, a zarazem reprodukując ją - tak samo, jak znaczenie słów zmienia się w czasie ich używania i z powodu używania" (tamże). W ujęciu autora struktura nie tylko przestaje być ograniczeniem dla działalności podmiotów, stając się zarazem jej możliwością, ale także nie jest już czymś „zewnętrznym”, niezależnym wobec nich, staje się „częścią” aktorów działających w konkretnych sytuacjach, wykorzystujących reguły i zasoby do wytwarzania i odtwarzania praktyk społecznych (Giddens 2003: 65). ,Struktury istnieją jedynie jako reprodukowane postępowanie umiejscowionych aktorów, posiadających intencje i interesy" (Giddens 2001a: 182).

A. Giddens objaśnia właściwości struktury i działania oraz ich wzajemną relację, odwołując się do posługiwania się językiem. Język można potraktować jako strukturę, a mowę - jako działanie (Giddens 2001a: 171). Mowę charakteryzuje umiejscowienie w czasie i przestrzeni, podczas gdy język pozostaje „wirtualny i poza czasem"; mowa zakłada istnienie podmiotu, a język jest bezpodmiotowy (mimo że nie istnieje, nie będąc używanym przez jednostki); mowa wymaga obecności drugiej osoby, a język jako struktura „nie jest ani zamierzonym wytworem jakiegokolwiek pojedynczego podmiotu, ani nie jest zorientowany na innych" (tamże: 171-172).

Już w przedstawionych powyżej założeniach teorii A. Giddensa odczytać można jego koncepcję jednostki jako „refleksyjnego podmiotu działającego" (Giddens 2003: 331). Refleksyjność aktora społecznego jest tu rozumiana jako „ciągłe monitorowanie działania własnego i oczekiwanego od innych”, kontrolowanie sytuacji, w której przebiegają interakcje i podejmuje się działania (tamże: 41). Niezbędne jest do tego podzielanie przez uczestników życia społecznego wspólnej, szczegółowej „wiedzy o konwencjach społecznych, o sobie samym i o innych ludziach, warunkującej umiejętność zachowania się w rozmaitych okolicznościach życia społecznego" (Giddens 2003: 65). Refleksyjność jednostki odnosi się także do tworzenia własnej koncepcji siebie. „Tożsamość jest projektem refleksyjnym, za który jednostka jest odpowiedzialna [...]. Jesteśmy nie tym, czym jesteśmy, ale tym co z siebie zrobimy" (Giddens 2001b: 99, 105). Giddens podkreśla, że jednostki są kompetentnymi aktorami, społecznymi teoretykami, „doświadczonymi socjologami”, wiedzącymi co robią i dlaczego, teoretyzującymi na temat własnych działań (Giddens 2003: 65). „Każdy człowiek jako aktor społeczny jest wysoce «wykształcony» - posiada wiedzę, którą stosuje, uczestnicząc w codziennych interakcjach i reprodukując je. [...] wiedza ta nie obejmuje 
i obejmować nie może wszystkich konkretnych sytuacji, w jakich aktor może się znaleźć; zapewnia mu raczej ogólną umiejętność reagowania na nieskończenie rozmaite okoliczności społeczne i wpływania na nie" (Giddens 2003: 61). Giddens wyróżnia wiedzę (świadomość) praktyczną - dominującą w codziennej działalności podmiotów - i wiedzę dyskursywną, obejmującą to, co ludzie potrafią powiedzieć na temat podejmowanych przez siebie czynności. „Na świadomość praktyczną składa się to wszystko, co aktorzy wiedzą o tym, jak «poruszać się» na scenie społecznej, ale czego nie potrafią wyrazić dyskursywnie" (Giddens 2003: 21). Pozostaje ona „nieuświadomiona” (Giddens 2001b: 51). Giddens podkreśla znaczenie tego rodzaju wiedzy, kluczowej w codziennej działalności aktorów społecznych, a do tej pory ignorowanej przez teorie socjologiczne odznaczające się „obiektywistycznym podejściem do zjawisk społecznych”, jak strukturalizm (Giddens 2003: 331).

Kluczową kategorią teorii strukturacji jest podmiotowe działanie, które autor charakteryzuje nie tylko jako refleksyjne, ale także racjonalne i celowe (Giddens 2001a: 10; 2003: 42-43, 46). „Działanie to wywoływanie zdarzeń, których sprawcą jest podmiot, w tym wszakże sensie, że w każdym momencie swej czynności mógłby postąpić inaczej” (Giddens 2003: 47). Racjonalność działania Giddens definiuje jako rozumienie przez aktorów przesłanek swojego postępowania - „od kompetentnych aktorów oczekuje się [...], że zapytani o to, potrafią zazwyczaj wytłumaczyć co czynią", dlaczego postąpili tak, a nie inaczej (tamże: 44). Autor odróżnia racjonalizację działania od motywacji - „O ile racje dotyczą przesłanek działania, o tyle motywy wyrażają powodujące je chęci, [...] skłonności do działania" (tamże: 44). Giddens zauważa, że dominującą formą codziennej działalności podmiotów są rutynowe praktyki, niebędące bezpośrednio motywowane (tamże: 332 ). Przez działanie intencjonalne lub celowe autor rozumie „każdy czyn, po którym aktor oczekuje (jest przekonany), że uzewnętrzni on pewną jakość bądź rezultat, i w którym stosuje posiadaną wiedzę, aby ową jakość lub rezultat wytworzyć" (Giddens 2001a: 117). Giddens wskazując na intencjonalność ludzkich działań, zwraca uwagę na ich możliwe niezamierzone konsekwencje, uboczny produkt refleksyjnych zachowań podmiotów, który może ,zwrotnie stanowić nierozpoznane warunki kolejnych czynów" (Giddens 2003: 46).

Twórca teorii strukturacji podkreśla także czasowo-przestrzenny charakter działań społecznych. Owo usytuowanie aktora jest czynnikiem wpływającym na jego swobodę działania. „Zakres podmiotowości ludzi jest ograniczony. Istoty ludzkie wytwarzają społeczeństwo, ale czynią to jako aktorzy usytuowani historycznie oraz w warunkach, na wybór których nie mieli wpływu" (Giddens 2001a: 225). Refleksyjność jednostek - ich zdolność monitorowania własnego działania, działania innych uczestników oraz całego kontekstu interakcyjnego - jest z kolei ograniczana $\mathrm{z}$ jednej strony przez nieświadomość, z drugiej zaś - przez nierozpoznane warunki działania lub jego niezamierzone konsekwencje (Giddens 
2003: 332). A. Giddens wymienia także takie ograniczenia podmiotowości jednostek, jak: ograniczenia materialne - związane z cielesnością człowieka oraz fizycznymi właściwościami materialnego świata; ograniczenia związane z sankcjami, mające swe źródło we władzy oraz ograniczenia strukturalne wynikające z okoliczności działania - „«obiektywnie» istniejące właściwości strukturalne, których podmiot działający nie jest w stanie zmienić" (tamże: 222). Autor podkreśla jednak zawsze dwojaki charakter ograniczeń - „wykluczają jedne działania, inne zaś umożliwiają" (tamże: 221).

Znaczną część swoich prac poświęca A. Giddens analizie nowoczesnego społeczeństwa czy nowoczesności. Terminem tym określa „, [...] instytucje i wzory zachowań, których początki sięgają końca europejskiego feudalizmu, chociaż znaczący wzrost ich realnego wpływu na losy świata zaznaczył się z całą intensywnością dopiero w wieku dwudziestym. Za odpowiednik «nowoczesności» można z grubsza przyjąć «świat uprzemysłowiony»" (Giddens 2001b: 21). W odniesieniu do współczesnego życia społecznego unika nazywania go „ponowoczesnym”, mówi raczej o „późnej nowoczesności”, uważa bowiem, że nie mamy dziś do czynienia z zupełnie nową formą społeczeństwa, ale raczej „,nową odmianą wciąż tego samego typu" (Szacki 2005: 888). Ponieważ cechy społeczeństwa, w którym przychodzi nam żyć, stanowią istotne ograniczenie bądź możliwości dla podmiotowości jednostki i decydują o takim a nie innym kształcie podejmowanych przez nią praktyk społecznych (także interesujących nas działań związanych z byciem kobietą/mężczyzną, matką/ojcem), niezbędne jest tu przedstawienie „osobliwości” nowoczesnego świata społecznego. Jak zauważa J. Szacki, „Giddensowska koncepcja nowoczesności jest wielowymiarowa, obok procesów ekonomicznych i społecznych obejmuje bowiem procesy polityczne; obok przemian makrospołecznych - przemiany mentalności, osobowości i najbardziej intymnych stosunków między ludźmi; obok zjawisk globalnych - mikrozjawiska życia codziennego; obok ideologii - na przykład postawy wobec czasu i przestrzeni" (Szacki 2005: 888). Tu skupimy się przede wszystkim na tych cechach współczesnego życia społecznego, które pozwolą zrozumieć zachowania jednostek realizujących role płciowe i rodzicielskie.

A. Giddens przypisuje refleksyjność nie tylko jednostce, ale całemu nowoczesnemu społeczeństwu, zaznaczając przy tym, że „[...] refleksyjność nowoczesności nie jest tym samym co właściwa wszelkiej ludzkiej aktywności refleksyjna kontrola działania. Refleksyjność nowoczesności oznacza, że większa część społecznej aktywności i materialnego stosunku do przyrody jest systematycznie poddawana rewizji ze względu na nowo zdobyte wiadomości lub nabytą wiedzę" (Giddens 2001b: 21). Przyczynił się do tego rozwój nauki i jej specjalizacja oraz coraz szerszy dostęp do specjalistycznej wiedzy, która ,jest w taki czy inny sposób bezustannie na powrót przejmowana i wykorzystywana jako własna przez laików" (tamże: 32). Wiedza naukowa przenika do wiedzy potocznej, zostaje wykorzystana przez „nieprofesjonalistów” do analizy własnych problemów, sy- 
tuacji życiowych oraz podejmowania takich a nie innych działań. „Wiedza nie tyle towarzyszy faktycznym zdarzeniom, ile współtworzy je. [...] Nauki społeczne nie tylko "gromadzą wiedzę», jak mogą to czynić nauki przyrodnicze, ale odgrywają kluczową rolę w procesie refleksyjności nowoczesności" (tamże: $20,29)$. Autor zwraca uwagę na istotną rolę socjologii jako nauki, która według niego „zajmuje centralne miejsce w nowoczesnej refleksyjności dzięki temu, że spełnia funkcję najbardziej ogólnej refleksji na temat nowoczesnego życia społecznego" (Giddens 2008: 30). Wiedza socjologiczna tym łatwiej, wydaje się, przenika do wiedzy potocznej, ponieważ dotyczy doświadczeń każdego człowieka jako członka społeczeństwa, wykorzystuje pojęcia z języka potocznego, a zatem nie jest hermetyczna, niedostępna, niezrozumiała dla laika, a poza tym jest popularyzowana w różnego rodzaju opracowaniach popularnonaukowych, poradnikach, artykułach i programach telewizyjnych, wypowiedziach ekspertów w mediach itp. (tamże: 101). „Dyskurs socjologii oraz pojęcia, teorie i ustalenia innych nauk społecznych stale «krążą tam i z powrotem» w przestrzeni, do której się odnoszą. [...]. Nowoczesność jest głęboko i ze swej natury socjologiczna" (tamże: 31). Giddens pokazuje na przykład, jak dane statystyczne oraz wyniki badań dotyczących małżeństwa i rodziny nie tylko kształtują określoną politykę państwa, ale także mają wpływ na jednostkowe decyzje: ,[...] potencjalnie rzecz biorąc, każdy, kto rozważa zawarcie małżeństwa, wyrabia sobie jakiś pogląd na to, jak instytucje rodziny ulegają zmianie, jak zmienia się pozycja społeczna i władza mężczyzn i kobiet, jak przekształcają zwyczaje seksualne itd. - a wszystko to bierze udział w procesie dalszych zmian, który dzięki refleksyjności jest tymi poglądami przepojony. Małżeństwo i rodzina nie byłyby tym, czym dzisiaj są, gdyby nie zostały na wskroś «zsocjologizowane» i «spsychologizowane»" (tamże: 38-39).

Inną specyficzną cechą nowoczesnego społeczeństwa jest jego zmienność. „Czymś, co w najbardziej oczywisty sposób odróżnia epokę nowoczesną od wszystkich poprzedzających ją okresów, jest niesłychany dynamizm. Nowoczesny świat «ucieka»: nie tylko tempo zmian jest nieporównanie szybsze niż w przypadku jakiegokolwiek wcześniejszego systemu, ale niespotykany jest także ich zasięg i radykalny wptyw, jaki wywierają na zastane praktyki i zachowania społeczne" (Giddens 2001b: 23). Ta zmienność uwarunkowana jest w dużej mierze wspominaną refleksyjnością - „,praktyki społeczne podlegają bezustannym przeglądom i reformom w świetle napływającej informacji o tych właśnie praktykach, co zmienia ich charakter w sposób konstytutywny" (Giddens 2008: 28). Autor zauważa, że taka „korekta konwencji” dokonuje się w każdej kulturze, jednak w nowoczesnym społeczeństwie „ulega zaostrzeniu”, z racji przenikania wiedzy eksperckiej do wiedzy potocznej, prowadzącego do podważania, kwestionowania utartych i, wydawałoby się, trwałych i niezmiennych poglądów i wzorów zachowań we wszystkich dziedzinach życia (tamże: 28). Giddens pisze o ,iskrzeniu nowoczesnego życia społecznego w zetknięciu z tradycyjnie 
ustalonymi praktykami” (Giddens 2001b: 30). Tradycja przestaje być czymś, co się bezrefleksyjnie przyjmuje i czego się przestrzega tylko dlatego, że „zawsze tak było”. „Rutyna życia codziennego traci immanentny związek z przeszłością, z wyjątkiem sytuacji, w której «to, co przeszłe» okazuje się zbieżne z tym, czego można pryncypialnie bronić w świetle nadchodzącej wiedzy. Praktyki nie sankcjonuje to, że jest tradycyjna; tradycja zyskuje usprawiedliwienie jedynie w świetle wiedzy, która sama nie podlega autentyzacji przez tradycję" (Giddens 2008: 27). We współczesnym świecie mamy do czynienia z „problematyzacją tradycji”, do czego przyczynia się także globalizacja i dostęp do innych wzorów kulturowych (Giddens 2009: 80). Autor nie ogłasza jednak „końca tradycji”, podkreślając, że nawet $\mathrm{w}$ najbardziej nowoczesnych społeczeństwach tradycje nie zanikają, a ,pod pewnymi względami i w niektórych warunkach wręcz rozkwitają” (tamże: 135). Pod jednym wszakże warunkiem: „tradycje moga przetrwać, jeśli poddaja się dyskursywnemu uzasadnieniu i jeśli są gotowe wejść $\mathrm{w}$ otwarty dialog nie tylko $\mathrm{z}$ innymi tradycjami, ale również $\mathrm{z}$ alternatywnymi sposobami postępowania" (tamże: 141).

Między innymi ze słabnącą rolą tradycji wiąże się kolejna właściwość nowoczesności - wpisana w nią niepewność i ryzyko. A. Giddens odnosi się do stwierdzenia Ulricha Becka, charakteryzującego nowoczesne społeczeństwo jako „społeczeństwo ryzyka”, podkreślając, że chodzi tu nie tyle o nowe zagrożenia, ale nieustanną niepewność człowieka co do warunków w jakich przychodzi i przyjdzie mu żyć. Do narastania owej niepewności przyczynia się rozwój nauki i techniki, zmieniających nieustannie świat, których to zmian jednostka nie jest w stanie przewidzieć, zrozumieć, kontrolować (Giddens 2001b: 40, 41). Ponadto rozwój nauki wcale nie daje pewnej i nieodwołalnej wiedzy, wręcz przeciwnie, ze względu na często sprzeczne diagnozy i proponowane rozwiązania określonych problemów społecznych, jednostka nie ma poczucia jasności i pewności co do otaczającej jej rzeczywistości i tego, jak postępować. „Nawet najrzetelniejszym autorytetom można wierzyć tylko «do odwołania», a systemy abstrakcyjne, które na wskroś przenikają życie codzienne, zamiast jednoznacznych wskazówek i instrukcji proponują wiele różnych możliwości. Do ekspertów zawsze można się zwrócić, ale oni sami często nie zgadzają się między sobą zarówno co do teorii, jak i praktycznych diagnoz” (tamże: 117). Wszelkie, także te „najbardziej pewne”, poglądy mogą zostać zakwestionowane, podważone, podane w wątpliwość (tamże: 195). Według A. Giddensa metafora Karla Poppera mówiąca o tym, że nauka nie ma trwałego podłoża i wznosi się na ruchomych piaskach, odnosi się do całego nowoczesnego świata (Giddens 2009: 119). „Względnie stały, dogłębny i gwałtowny bieg zmian, jakie charakteryzują nowoczesne instytucje, wraz z ustrukturyzowaną refleksyjnością oznacza, że zarówno na poziomie codziennych praktyk, jak i filozoficznych interpretacji nic nie można uznać za pewne. Sposób postępowania, który dziś jest poprawny-odpowiedni-i-zalecany, jutro, w świetle nowych okoliczności lub odkryć, może już być postrzegany zupełnie 
inaczej” (Giddens 2001b: 184). Podczas gdy „w społeczeństwach przednowoczesnych tradycja zapewniała względnie stabilny horyzont działań" (Giddens 2009: 104), w późnej nowoczesności członkowie społeczeństwa nie dysponują takimi „przepisami”, wskazującymi „co się powinno robić” i ,zapewniającymi pewien poziom bezpieczeństwa ontologicznego tym, którzy ich przestrzegają" (tamże: 91). „Tradycja lub ustanowiony obyczaj z definicji nakazują życie w stosunkowo sztywno ustalony sposób. Nowoczesność stawia przed jednostką całą gamę rozmaitych możliwości, a równocześnie, $\mathrm{z}$ racji braku fundamentalistycznych zapędów, nie udziela wskazówek, które z nich powinno się wybrać" (Giddens 2001b: 112). Doświadczenie jednostkowe jest także „odseparowane” od doświadczeń innych osób, które mogłyby stać się dla niej wyznacznikiem własnych działań. Jest to wynik m.in. oderwania jednostki od rodziny pochodzenia, dostarczającej gotowych wzorów zachowań, wspierającej w podejmowaniu ważnych decyzji itp. (tamże: 202-203).

Nieodłączną cechą życia w nowoczesnym świecie jest ciągła konfrontacja z wieloma możliwymi sposobami działania, kreowania siebie i własnej egzystencji oraz konieczność wyboru wraz z towarzyszącym takim decyzjom ryzykiem. A. Giddens wskazuje następujące źródła wielości wyborów, z którą zmierzyć się musi jednostka w warunkach późnej nowoczesności: a), „życie w porządku posttradycyjnym" (brak jednoznacznych wytycznych wynikających z tradycji); b) zjawisko „pluralizacji stylów życia”; c) ,zależność usankcjonowanych przekonań od kontekstu" (niepewność wiedzy, wielość koncepcji, teorii, rozwiązań określonych problemów itp.); d) „doświadczenie funkcjonowania jednostki w wielu różnych środowiskach społecznych" (Giddens 2001b: 115-117). Autor zaznacza przy tym, że w przypadku każdej jednostki wybór możliwych sposobów postępowania, chociaż bardzo szeroki, jest w pewnym stopniu ograniczony - „Wielość stylów życia [...], nie oznacza, że wszystkie możliwości są na równi dostępne każdemu albo że ludzie przy dokonywaniu wyborów są zawsze świadomi wszelkich dostępnych im możliwości" (tamże: 114).

Podsumowując, teoretyczne ramy pracy podejmującej problematykę ról płciowych i rodzicielskich realizowanych przez młodych wykształconych Polaków stanowi teoria strukturacji A. Giddensa oraz jego koncepcja nowoczesności. Przyjęto, że role społeczne są efektem działań jednostek, a takie ujęcie bliskie jest przedstawionej wyżej teorii traktującej świat społeczny jako wytwór podmiotowej działalności ludzi. Podejście to pozwala na uczynienie przedmiotem zainteresowania „praktyk społecznych” - konkretnych działań konkretnych ludzi, mających miejsce w określonych społecznych sytuacjach - oraz uwzględnienie w ich analizie zarówno perspektywy społecznej, jak i jednostkowej, uchwycenie w pełnionych przez jednostki rolach elementu strukturalnego i indywidualnego. Umożliwia zrozumienie trwałości oraz zmienności takich „odwiecznych” wzorów zachowań, jak właśnie zachowania związane z rolą kobiety/mężczyzny, matki/ojca w warunkach późnej nowoczesności. 


\subsection{Wybrana koncepcja roli społecznej w perspektywie teorii strukturacji}

W przedstawionych rozważaniach A. Giddensa na temat świata społecznego i podmiotowości jednostek nie pojawiło się pojęcie roli społecznej. Autor mówi o działaniach i praktykach społecznych. Do pojęcia roli społecznej odnosi się niechętnie, poddając krytyce strukturalno-funkcjonalną koncepcję roli i ujmowanie jej jako elementu normatywnego porządku społeczeństwa, coś stałego, danego, zastanego przez jednostkę, jak widział to T. Parsons (Giddens 1979: 116; 2003: 126; 2004: 51). A. Giddens odrzuca koncepcję społeczeństwa jako systemu - sieci ról i traktowanie roli społecznej jako łącznika między osobowością jednostki i strukturą społeczną (tamże). W jego teorii rzeczywistość społeczną tworzą reprodukowane przez ludzi społeczne praktyki (tamże). Co ciekawe, autor poddaje krytyce pojęcie roli sformułowane przez strukturalny funkcjonalizm, a nie odnosi się (poza odwołaniem do dramaturgicznej koncepcji roli Goffmana) do sposobu rozumienia roli społecznej wypracowanego w ramach symbolicznego interakcjonizmu, bliskiego mu pod względem traktowania jednostki jako działającego i negocjującego znaczenia podmiotu. A przecież koncepcja role making wpisuje się w wizję świata społecznego wypracowaną na gruncie teorii strukturacji. Łączy je przyjęcie podmiotowości jednostki i jej działań jako podstawy rzeczywistości społecznej oraz społecznych analiz. Jednak zgodnie ze stanowiskiem A. Giddensa, aby nie wpaść w subiektywizm i wspominany ,imperializm podmiotu" zarzucany socjologii interpretatywnej przez autora, nie można tracić z oczu strukturalnych właściwości ludzkich działań. Takimi elementami struktury istniejącymi w odtwarzanych i tworzonych przez aktorów praktykach społecznych byłyby przepisy roli (role prescriptions), którym to pojęciem posługuje się sam autor teorii strukturacji (Giddens 1979: 117). A. Giddens postuluje postrzeganie ról (przepisów ról) tylko w powiązaniu ze społecznymi praktykami - czyli powtarzalnymi, codziennymi działaniami jednostek - oraz nietraktowanie ich jako „danych" (given) oraz uzgodnionych (consensual) (tamże: 118). A zatem role społeczne można traktować jako reguły, czyli procedury postępowania, do których odwołują się aktorzy w codziennym życiu społecznym, reprodukując je i zarazem przetwarzając $\mathrm{w}$ swoich działaniach. W ramach teorii strukturacji możliwe jest pogodzenie koncepcji przyjmowania roli (role taking) i tworzenia roli (role making). Jednostka wytwarza i zarazem reprodukuje strukturę (tu jej element: przepisy roli), która stanowi zarówno warunek, jak i rezultat interakcji i działań aktorów społecznych. Przypomnijmy: „każdy moment reprodukowania jest zarazem nieuchronnie momentem wytwarzania" (Giddens 2001a: 150). Autor podkreśla aspekt normatywny przepisów ról oraz ich powiązanie z tożsamością społeczną jednostek, w którą, według autora, wpisane są określone oczekiwania społeczne, przywileje i obowiązki (Giddens 1979: 118; 2004: 51). Znajomość przepisów ról 
stanowi komponent podzielanej wiedzy praktycznej, pomaga w interpretacji sytuacji i zachowań partnera interakcji, dostarcza strategii postępowania, umożliwia refleksyjne monitorowanie własnej działalności i działań innych uczestników.

Unikanie przez A. Giddensa pojęcia roli społecznej i włączenia go do rozważań dotyczących wzajemnych relacji jednostki i społeczeństwa ${ }^{4}$ wydaje się nieuzasadnione. Tym bardziej, że jak zauważył Henryk Białyszewski, „przy użyciu pojęcia roli możemy łatwiej niż przy użyciu innych pojęć (np. grupy lub działania społecznego) uwzględniać wpływ czynników osobowościowych i kulturalnych na strukturę społeczną i odwrotnie" (Białyszewski 1967: 195). Cytowany autor używa pojęcia struktury w tradycyjnym, „przedgiddensowskim” rozumieniu, niemniej wskazuje, że zagadnienie roli społecznej pozwala na uchwycenie wzajemnego oddziaływanie na siebie tego co społeczne i tego co jednostkowe, indywidualne. Być może A. Giddensa zniechęciły niedoskonałości wcześniejszych sposobów rozumienia roli społecznej, na co mogłaby wskazywać jego krytyka. W bogatym dorobku socjologicznym poświęconym tej problematyce można jednak znaleźć koncepcję roli społecznej przezwyciężającą, jak teoria strukturacji, dychotomię w socjologii (woluntaryzm - determinizm), łączącą w sobie normatywny i behawioralny aspekt roli, ujmującą zarówno jej społeczny, jak i indywidualny charakter. Warunek ten spełnia podejście Daniela Levinsona, spopularyzowane na gruncie polskim przez Jacka Szmatkę, który określił je mianem „,integralnego” (Levinson 1978; Szmatka 1973: 161; 1989: 196-202; 2000: 323). Zdzisława Kawka, przedstawiając teorię roli jako kontinuum od skrajnie strukturalno-funkcjonalnego pojmowania roli (reprezentowanego przez R. Dahrendorfa i T. Parsonsa) do skrajnie indywidualistycznego (podejście E. Goffmana, H. Blumera), umieściła koncepcję D. Levinsona pośrodku skali, co również potwierdza jej integralny charakter (Kawka 1998: 23).

Podkreślmy, że J. Szmatka omawiając tę koncepcję, pisze o „roli społecznej danej jednostki”, czy o „indywidualnej roli społecznej”, wskazując tym samym, że nie ma ról samych w sobie, jako takich, ról w ogóle (Szmatka 1989: 196, 197). Tak jak widzieli je strukturaliści, postrzegający społeczeństwo jako sieć pozycji i powiązanych z nimi ról, które jakby „czekały” na jednostkę. W prezentowanym podejściu rola istnieje dopiero w działaniu, to aktor społeczny ,powołuje ją do życia”. Rola społeczna jest tu ukazana jako coś złożonego, wielopłaszczyznowego. W wewnętrznej strukturze roli społecznej autor wyodrębnia dwa poziomy: poziom ,społeczny”, odpowiadający Giddensowskiej strukturze, oraz poziom ,jednostkowy", odpowiadający działającemu aktorowi, odgrywającemu daną rolę. Mamy tu zatem strukturalnie narzucane nakazy roli, czyli wymogi dotyczące

${ }^{4}$ Więcej miejsca poświęca temu autor jedynie w jednej z wcześniejszych, cytowanych tu prac: Anthony Giddens, Central Problems In Social Theory. Action, structure and contradiction in social analysis, University of California Press, Berkeley 1979. 
działań jednostki (Szmatka 1989: 196). Byłyby to wspominane przez A. Giddensa „przepisy roli”, reguły - elementy struktury, tworzące ramy dla codziennej działalności i interakcji społecznych, będące i ich ograniczeniem, i możliwościami. Wśród tych społecznych standardów zachowania wyróżnić można ułatwienia roli, czyli „określone czynniki natury technicznej, ekologicznej, a przede wszystkim kulturowej, które powodują, iż pewne normy wchodzące w skład nakazów i wymogów roli są szczególnie łatwo zauważalne" oraz dylematy roli, czyli problematyczne kwestie - „takie normy, wartości, nakazy itp., które są nieostro sformułowane, wieloznaczne" (tamże: 197-198). W osobowościowej definicji roli natomiast zawiera się własna koncepcja roli jednostki - nakazy i wymogi zinterpretowane przez jednostkę oraz aspekt behawioralny - odgrywanie roli. Jak stwierdza Daniel Levinson, w sposobie definiowania roli przez jednostkę wyraża się jej osobowość, ,próby konstruowania przez jednostkę własnej rzeczywistości społecznej, określenia w niej własnego miejsca i osiągnięcia osobistego zadowolenia i uznania" (Levinson 1978: 137). Aktorzy społeczni tworząc własne koncepcje roli, odwołują się oczywiście do społecznych reguł - strukturalnie narzuconych nakazów, reprodukując je, a jednocześnie je tworząc poprzez własną interpretację $\mathrm{i}$,selektywne” podejście do reguł. D. Levinson zaznacza: „Indywidualna koncepcja roli i indywidualne pełnienie roli nie emanują z głębin świadomości całkowicie ukształtowane ani też nie są lustrzanymi odbiciami szablonu ustalonego przez strukturę społeczną" (tamże: 139). Jednostkowa definicja roli wraz z jej faktyczną realizacją odpowiada Giddensowskim ,praktykom społecznym". Podkreślić tu należy wzajemną zależność strukturalnie narzuconych nakazów roli (struktura) oraz osobowościowej definicji roli (działanie jednostki). Jednostka tworzy i realizuje własną koncepcję roli poprzez interpretację i ,,selektywne" podejście do reguł, tym samym reprodukując je i tworząc jednocześnie (dualizm struktury).

Do zaproponowanej tu koncepcji roli społecznej można odnieść wprowadzone w pierwszej części niniejszego rozdziału pojęcia modelu i wzoru. Model roli społecznej obejmowałby strukturalnie narzucane nakazy roli, przepisy roli, wizję, jak powinna zachowywać się jednostka ją pełniąca. Nie mamy tu działającego aktora społecznego, jedynie reguły, do których odwołują się ludzie w określonych sytuacjach społecznych i interakcjach. Jednostki posiadają wiedzę na temat pożądanych, oczekiwanych zachowań (modeli). Jest to wiedza podzielana przez członków danej grupy społecznej czy danego społeczeństwa. Wzór roli społecznej zawierałby natomiast już „pełną” strukturę roli - zarówno strukturalnie narzucane nakazy roli, jak i osobowościową definicję roli, społeczne oczekiwania i subiektywną ocenę tych oczekiwań, ich indywidualną interpretację. W ten sposób chwytamy role jednostkowe, indywidualne, realizowane przez aktorów w konkretnych sytuacjach życiowych. Modele zatem byłyby elementem struktury - ramami, w jakich działa jednostka, a wzory - określonymi działaniami ludzi - społecznymi praktykami, tworzącymi społeczną rzeczywistość. 
Podsumowując, powiązanie proponowanej koncepcji roli społecznej z teorią strukturacji A. Giddensa uwydatnia traktowanie ról społecznych jako efektu działań realizujących je podmiotów, zwraca uwagę na proces ich tworzenia, negocjowania przez aktorów społecznych. Takie spojrzenie na rolę społeczną, a także jednostkę i jej relację do społecznej rzeczywistości pozwala na lepsze i pełniejsze uchwycenie i zrozumienie podjętej problematyki społecznych ról płciowych i rodzicielskich realizowanych przez młodych wykształconych Polaków. W świetle teorii strukturacji w swoich działaniach jednostki odtwarzają i jednocześnie tworzą role społeczne - tu: role kobiety/mężczyzny, matki/ojca. Odtwarzają - bo odwołują się na przykład do sposobu realizacji tych ról przez swoich rodziców, pozostałych znaczących innych, czy do modelu ról funkcjonującego w społeczeństwie, do którego należą. Tworzą - bo sytuacja każdej jednostki jest jedyna w swoim rodzaju i niepowtarzalna ze względu na jej cechy osobowe, potrzeby, przeszłe doświadczenia, świadomość dyskursywną i praktyczną, a także takich a nie innych partnerów interakcji - w tym przede wszystkim partnerów w związkach intymnych, którzy definiując w określony sposób swoje role płciowe i rodzicielskie, wpływają na sposób ich definiowania i realizacji przez jednostkę. 



\section{Rozdział 2. Tradycyjny model kobiecości i męskości}

\subsection{Płeć biologiczna i kulturowa - definicje, koncepcje}

Mówiąc o modelach płci, rozumiemy je jako kulturowe definicje kobiecości i męskości. Odwołujemy się tym samym do rozróżnienia między płcią biologiczną (sex) i płcią kulturową czy społeczno-kulturową (gender). Pierwsze z pojęć odnosi się do anatomicznych i fizjologicznych różnic między kobietami i mężczyznami, drugie - do różnic psychologicznych, społecznych i kulturowych, będących efektem „społecznego procesu konstruowania płci” (Giddens 2004: 128). Każde społeczeństwo przyjmuje określone koncepcje kobiecości i męskości, obejmujące cechy, zachowania i role społeczne uznane za typowe i pożądane dla obu płci, przyswajane przez jednostki w procesie socjalizacji (Gontarczyk 1995; Sekuła-Kwaśniewicz 2000: 122). W literaturze anglojęzycznej płeć jako zjawisko społeczne określane jest mianem ,rodzaju” (gender), stąd mówi się o rolach rodzajowych czy stereotypach rodzaju (Brannon 2002)1. W polskiej refleksji nad problematyką kulturowych konstruktów kobiecości i męskości wiele miejsca poświęcono trudnościom związanym z właściwym nazwaniem tego zjawiska (Gontarczyk 1995; Sekuła-Kwaśniewicz 2000; Walczewska 2001; Dybel 2006: 8; Titkow 2007: 27). Polscy autorzy używają najczęściej pojęcia „płeć kulturowa”, dzięki czemu wyraźnie zaznacza się, iż chodzi o „«kulturową nadbudowę» płci biologicznej" (Titkow 2007: 27). Powszechnie używane jest także angielskie słowo gender (także gender studies) i tworzone od niego pojęcia, na przykład genderyzacji społeczeństwa, genderowej problematyki czy genderowego podejścia do analizy życia społecznego.

Odwołując się do literatury przedmiotu, można wyodrębnić trzy ogólne teorie płci, występujące w naukach społecznych, w różny sposób wyjaśniające różnice między kobietami i mężczyznami (Bem 2000; Bradley 2008; Giddens 2004; Kimmel 2004; Wharton 2005). Pierwsze stanowisko określane jest mianem esencjalizmu biologicznego, podejścia socjobiologicznego, biologizmu, biocentryzmu czy naturalizmu (Bem 2000; Pakszys 2000; Arcimowicz 2003; Głażewska 2005). Odmienne cechy osobowości, usposobienie, zachowania i role społeczne kobiet

${ }^{1}$ Niektórzy polscy autorzy (na przykład Gontarczyk 1995) i tłumacze (na przykład Bem 2000, tłum. S. Pikiel) preferują stosowanie bezpośrednio tłumaczonego z języka angielskiego terminu „rodzaj”. Krytycy tego podejścia zwracają uwagę na zatracanie w ten sposób właściwego znaczenia tego pojęcia, tj. społeczno-kulturowego wymiaru płci (Dybel 2006: 8; Titkow 2007: 27). W związku z tym, na przykład pojęcie „roli rodzajowej” jest abstrakcyjne i niezrozumiałe dla przeciętnego czytelnika, nieobeznanego z nomenklaturą nauk społecznych, podejmujących problematykę płci. 
i mężczyzn wyjaśniane są naturalnymi, biologicznymi - anatomicznymi i fizjologicznymi - różnicami między płciami. Dowodem na determinizm biologiczny określonych wzorów kobiecości i męskości ma być istnienie różnic między płciami we wszystkich społeczeństwach. Wskazuje się, że podział pracy według płci oraz dominacja mężczyzn to efekt procesu ewolucji (Bem 2000: 31; Arcimowicz 2003: 34). Teorie te nie uwzględniają roli kultury i wpływu społecznego w kształtowaniu osobowości i zachowań jednostki.

Drugie podejście do problematyki płci to teorie socjalizacji do ról związanych z płcią (można spotkać się także z określeniem ,socjalizacja rodzaju” - gender socialization) (Bem 2000: 130; Wharton 2005: 31). U ich podstaw leży wspominane na początku rozróżnienie sex i gender. Jak pisze Dorota Panowska, ,z biologicznego punktu widzenia człowiek rodzi się jako osobnik płci męskiej lub żeńskiej, ze społeczno-kulturowego zaś - staje się mężczyzną lub kobietą" (Pankowska 2005: 65). Przedmiotem zainteresowania jest tu proces uczenia się przez jednostkę zachowań oczekiwanych od niej jako kobiety/mężczyzny, nabywania określonych cech, aspiracji, zainteresowań, kształtowania się jej tożsamości płciowej (Bardwick, Douvan 1982; Mandal 1995; Buczkowski 1997; Bem 2000; Brannon 2002; Lott, Maluso 2002; Renzetti, Curran 2005; Pankowska 2005). Analizowane są kolejne etapy socjalizacji w zakresie płci kulturowej, jej mechanizmy i czynniki. Wymienia się tu m.in.: teorię społecznego uczenia się, teorię schematów rodzajowych, teorię poznawczo-rozwojową, teorię scenariusza rodzaju czy teorię psychoanalityczną (Brannon 2002; Renzetti, Curran 2005). W podejściu tym różnice między kobietami i mężczyznami, przejawiające się w odmiennych cechach, zachowaniach, rolach społecznych tłumaczy się istnieniem różnych społecznych definicji kobiecości i męskości i, co za tym idzie, innych oczekiwań i norm dotyczących każdej z płci, przyswajanych przez jednostkę w procesie socjalizacji.

W ramach trzeciego stanowiska wyjaśniającego „naturę” płci i różnice między kobietami i mężczyznami, przyjmuje się, że zarówno sex jak i gender ,są pozbawione podstaw biologicznych i są w całości produktem społecznego procesu konstruowania płci" (Giddens 2004: 128). Na podstawie analizy zmiany wyglądu i budowy ciała kobiet i mężczyzn na przestrzeni wieków stwierdzono, że „ostry podział między naturą i kulturą nie daje się utrzymać, ponieważ to, co «naturalne», jest po części konstruowane społecznie" (Bradley 2008: 30). Różnice biologiczne między kobietami i mężczyznami traktowane w ramach wcześniej omówionych teorii jako ,naturalne” i pozostające poza wpływem społecznym, zaczęto traktować jako społeczny konstrukt (Wharton 2005: 55). To bowiem w ramach danej kultury przypisuje się znaczenie określonym cechom fizycznym kobiet i mężczyzn, eksponuje je bądź ukrywa itd. Zwrócono uwagę, że ciało i „naturalne”, biologiczne cechy człowieka są poddawane nieustannemu społecznemu oddziaływaniu, rozmaitym zabiegom takim jak dieta, aktywność fizyczna, sposób ubierania się i makijaż, operacje plastyczne, wreszcie - operacje zmiany płci (Giddens 2004: 132). Ellyn Kaschack pokazuje, jak kobiety w zachodnich społeczeństwach 
„zmieniają swoje ciało i ograniczają jego ruchy”, aby, jak pisze autorka, „podtrzymać iluzję dychotomii” i udowadniać swoją „kobiecość” (Kaschack 1996: 51). „Dzięki golarkom, depilatorom, pęsetom, fryzurom, makijażom, lakierom do paznokci, nylonom, szpilkom, biustonoszom, które podtrzymują, powiększają lub pomniejszają, oraz obcisłym ubraniom - wygląd kobiety zasadniczo różni ją od mężczyzny" (tamże).

W konstruktywistycznym podejściu do płci rozróżnienie na sex i gender przestaje mieć znaczenie, bowiem płeć jest traktowana nie jako właściwość jednostki, ale cecha sytuacji, ,,produkt interakcji” (Brannon 2002: 39; Kimmel 2004: 107; Mandal 2005: 37). Jak ujmuje to Katarzyna Gawlicz, „męskość i kobiecość (jak również chłopięcość i dziewczęcość) nie są stałymi, niezmiennymi danymi, ale płynnymi, możliwymi do zmodyfikowania wytworami codziennych interakcji” (Gawlicz 2009: 89). W kluczowej dla tego sposobu ujmowania płci pracy Doing gender autorzy Candence West i Don Zimmerman (1987) stwierdzają, że „to ludzie tworzą płeć, bardziej niż ją posiadają [do gender rather than have gender]" (za: Mandal 2005: 37). Podkreśla się tu znaczenie kontekstu społecznego, w jakim przebiega interakcja i jednostki zachowują się w określony sposób. A, jak stwierdza Ewa Hyży, „,nie ma takiego społecznego kontekstu, który byłby wolny od aspektu rodzajowego (który nie byłby «nacechowany rodzajowo» [gendered]" (Hyży 2003: 62). Judith Butler proponuje, by płeć traktować jako formę „publicznego działania”, ,akt odgrywania” bycia mężczyzną/kobietą w codziennych interakcjach z innymi, rodzaj performance'u, który poprzez ciągłe odtwarzanie utrwala określone wzory kobiecości i męskości oraz relacji między nimi, uznawane za „dane, naturalne, oczywiste” (Butler 1990, za: Glover, Kaplan 2007: 18; Bradley 2008: 32; Tokarczuk 2008: 8). W ramach swojej teorii performatywności płci autorka dowodzi, że „to, co bierzemy za wewnętrzną istotę płci, jest wytwarzane w nieprzerwanej serii aktów, że przyjmujemy jej istnienie, ponieważ ciało zostaje na daną płeć wystylizowane" (Butler 2008: 19). A zatem nie mają sensu próby odróżniania biologicznych i kulturowych aspektów płci, nierozerwalnie ze sobą złączonych i stwarzanych w codziennie odgrywanym „rodzajowym show” (Bradley 2008: 32; Tokarczuk 2008: 8).

Jak zauważa H. Bradley, obecnie koncepcje stwarzania płci (autorka proponuje tu używanie pojęcia „upłciawiania” - gendering), wypierają teorie socjalizacji płciowej, którym zarzuca się determinizm i traktowanie jednostki jako biernej, poddającej się wpływom społecznym i odgrywającej rolę kobiety/mężczyzny w narzucanym przez społeczeństwo kształcie (Bradley 2008: 37). Ponadto, takie ujęcie procesu stawania się osobą o określonej płci kulturowej nie uwzględnia zmian w zakresie scenariuszy ról płciowych i innych możliwych sposobów na realizowanie płci niż tylko bycie kobietą czy bycie mężczyzną o określonych cechach, zainteresowaniach, zachowaniach. Zdaniem autorki, „o ile niektóre starsze spostrzeżenia z zakresu socjalizacji są pomocne w wyjaśnianiu, skąd biorą się idee normalności, oraz w ujawnianiu presji, jakiej jako jednostki jesteśmy poddawani, 
by być «normalnymi», o tyle bardziej dynamiczna koncepcja upłciawiania umożliwia nam zbadanie, jak jednostki rozwijają się jako podmioty działające, pozostające w interakcji ze swym środowiskiem" (tamże).

Podsumowując dotychczasowe rozważania poświęcone różnym koncepcjom płci, można zauważyć, że w pierwszym podejściu nie rozróżnia się płci biologicznej i kulturowej, zakładając, że płeć człowieka, z jej cechami, rolami, statusem społecznym oraz różnice między kobietami i mężczyznami to efekt biologii i procesu ewolucji. W drugim ujęciu oddziela się biologiczne aspekty płci od płci kulturowej, określanej w ramach danego społeczeństwa i „nakładanej” na jednostkę w procesie socjalizacji. Wskazuje się tu zatem dwa „źródła” kobiecości i męskości - naturę oraz kulturę. Wreszcie trzecie stanowisko nie uwzględnia biologicznych podstaw płci jednostki, wskazując że kobiecość i męskość, także w ich wymiarach fizycznych, cielesnych, jest przede wszystkim wytworem społeczno-kulturowym. W niniejszej pracy skłaniamy się ku drugiemu podejściu, odrzucając jednak wizję ,przesocjalizowanej” jednostki i dostrzegając jej aktywną rolę w realizowaniu własnej kobiecości/męskości. Wiąże się to z przyjęciem koncepcji roli społecznej nieograniczającej się do jej normatywnych aspektów i uwzględniającej podmiotowość oraz indywidualność społecznych aktorów.

Szeroko rozumiana problematyka płci była obecna w myśli społeczno-filozoficznej od samego początku (Gontarczyk 1995: 29; Malinowska 2000: 21). Już w pracach starożytnych filozofów odnaleźć można rozważania na temat natury kobiecości i męskości i różnic miedzy nimi. W literaturze przedmiotu zwraca się uwagę, że do wzrostu zainteresowania zagadnieniem płci i różnic między kobietami i mężczyznami przyczynił się Zygmunt Freud i jego teoria psychoanalizy. Jak stwierdził Paweł Dybel, „to dopiero od czasów Freuda płeć i życie seksualne człowieka przestały być traktowane wyłącznie jako ukształtowane przez biologiczne własności ludzkiego ciała" (Dybel 2006: 7). Oprócz wpływu kultury na popędową i seksualną naturę człowieka zaczęto dostrzegać znaczenie bycia kobietą/mężczyzną dla tożsamości jednostki. Przy czym zwracano uwagę nie tyle na różnice w budowie ciała kobiety i mężczyzny, co na wyobrażenia odnoszące się do tych różnic, odgrywające dużą rolę w kształtowaniu się osobowości i tożsamości przedstawicieli obu płci (tamże: 455, 473). „Decydujące znaczenie ma interpretowanie przez dziecko braku penisa u dziewczynki jako kastracji” (tamże: 456). Prowadzi ono bowiem do przekonania o „niepełnowartościowości” i swoistym „wybrakowaniu” kobiet.

Punktem zwrotnym w refleksji nad płcią były antropologiczne badania plemion nowogwinejskich przeprowadzone przez Margaret Mead w latach trzydziestych ubiegłego wieku (Głażewska 2005: 85). W książce Pteć i charakter w trzech społecznościach pierwotnych autorka pokazała, że każde społeczeństwo tworzy własne modele i wzory kobiecości i męskości, przy czym nie zawsze odwołują się one do różnych cech i ról (Mead 1986). I tak, zarówno w plemieniu Arapeshów jak i plemieniu Mundugumorów badaczka nie zaobserwowała różnic 
charakterologicznych między kobietami i mężczyznami (tamże: 142, 227). Przy czym w pierwszej społeczności od jej członków, bez względu na płeć, oczekiwano współpracy, nastawienia na dobro wspólne, troski o innych, opiekuńczości, łagodności, wrażliwości (a zatem cech traktowanych w naszej kulturze jako kobiece), w drugiej zaś ideał osobowy identyczny dla obu płci zawierał takie cechy, jak: ,porywczość, duch rywalizacji, agresywność seksualna, zazdrość i gotowość do zauważenia i natychmiastowego pomszczenia obelgi, upodobanie do popisu, do działania i do walki" (w naszej kulturze - cechy przypisywane mężczyznom) (tamże). W obu plemionach nie dostrzegano różnic $\mathrm{w}$ charakterach obu płci. W trzeciej opisywanej przez M. Mead społeczności (Tchambuli) kobiety i mężczyźni charakteryzowali się różnymi cechami, innymi jednak niż w patriarchalnych społeczeństwach europejskich. Kobiety odpowiadały tu za zapewnienie rodzinie pożywienia i dochodów oraz pełniły funkcję głowy domu, dominowały w relacjach z partnerem (także tych seksualnych) (Mead 1986: 264, 266-267). Mężczyźni natomiast byli artystami, specjalizującymi się w określonej sztuce, poświęcającymi jej całą swoją aktywność, uzależnionymi emocjonalnie, ale i materialnie od swoich żon (tamże: 247). Jak określiła ten porządek ról M. Mead, mając za punkt odniesienia współczesne jej społeczeństwo amerykańskie: w plemieniu Tchambuli mamy do czynienia z „odwróceniem związanych z płcią postaw panujących w naszej kulturze”, czyli z męskimi kobietami oraz kobiecymi mężczyznami (Mead 1986: 279; Głażewska 2005: 94).

O nowym podejściu do zagadnienia płci można mówić od lat 60.-70. ubiegłego wieku, w związku z podjęciem badań nad kobietami (women's studies) w ramach ruchu feministycznego „drugiej fali” (Gontarczyk 1995: 29; Bradley 2008: 27). Owa „nowość” polegała właśnie na wprowadzeniu rozróżnienia między płcią biologiczną i kulturową. Jako znaczącą dla określenia społeczno-kulturowego wymiaru płci wymienia się pracę psychologa Roberta Stollera Sex and Gender: On the Development of Masculinity and Femininity (1968), a w dziedzinie socjologii i studiów feministycznych pracę Ann Oakley Sex, Gender and Society (1972) (Bradley 2008: 27). Kobiecość i męskość zaczęły być traktowane jako kulturowy fenomen, społeczny konstrukt (Beall 2002). Słuszności takiego podejścia do płci dowodziły, zdaniem badaczy, obserwowane już przez M. Mead różnice między społeczeństwami w definiowaniu kobiecości i męskości, ale także zmiany w sposobie postrzegania kobiet i mężczyzn w ramach jednej kultury w ujęciu historycznym. Pokazywano różnorodność kulturowych definicji płci w odniesieniu do różnych etapów życia człowieka, a także w odniesieniu do różnych kategorii społecznych. Zauważono, bowiem, że w formułowaniu społecznych oczekiwań wobec jednostki o określonej płci oraz doświadczaniu przez nią własnej „płciowości” odgrywają rolę także inne istotne cechy społeczno-demograficzne, takie jak pochodzenie etniczne, pochodzenie społeczne i geograficzne, przynależność klasowa, wykształcenie, orientacja seksualna czy wspominany już wiek (Kimmel 2004: 94-95). Stąd nie można mówić o jednej „kobiecości” i jednej „męskości” 
funkcjonującej w ramach danej kultury (Glover, Kaplan 2007: 19). Ponadto zwracano uwagę na relacyjny charakter płci kulturowej (Gender is relational), tj. wzajemną relację między konstruktami kobiecości i męskości, definiowanie jednej poprzez porównanie z drugą (Kimmel 2004: 97). Wreszcie, wskazywano na ich sytuacyjność (Gender is situational), tj. zmienność określenia, co znaczy być kobietą/mężczyzną w zależności od kontekstu, co prowadzi do wspomnianego już traktowania płci kulturowej nie jako „własności” jednostki, lecz sposobu zachowania się będącego rezultatem określonej społecznej sytuacji (tamże).

Odrzucenie determinizmu biologicznego i zwrócenie uwagi na społeczno-kulturowe podstawy kształtowania się kobiecości i męskości pozwoliło na wyjaśnienie różnic $\mathrm{w}$ psychologii kobiet i mężczyzn, a przede wszystkim różnic w funkcjonowaniu przedstawicieli jednej i drugiej płci w społeczeństwie (np. odmienne role społeczne i płaszczyzny aktywności) oraz zjawiska społecznych nierówności płci. Jest to przedmiot zainteresowania tzw. paradygmatu feministycznego w socjologii czy socjologii feministycznej (Renzetti, Curran 2005: 19; Babbie 2008: 54).

W celu uporządkowania pojęć i zagadnień związanych z problematyką płci kulturowej proponujemy ich krótkie omówienie, wyodrębniając dwa analityczne wymiary gender: wymiar społeczny oraz jednostkowy, indywidualny. W tej pierwszej perspektywie traktujemy płeć kulturową jako: 1) normę wyznaczającą zachowania członków społeczeństwa należących do jednej lub drugiej kategorii płci; 2) „narzędzie” służące porządkowaniu, kategoryzowaniu rzeczywistości społecznej przez klasyfikowanie jednostek jako kobiet lub mężczyzn o określonych cechach i rolach społecznych (stereotypy płci); 3) czynnik stratyfikacji społecznej; 4) właściwość życia społecznego, ujawniającą się w różnych instytucjach społecznych (gendered society); 5) wymiar kultury. W ujęciu jednostkowym przedmiotem zainteresowania jest codzienne doświadczenie jednostki posiadającej określoną płeć biologiczną i kulturową oraz jej tożsamość płciowa.

\subsubsection{Wymiar społeczny}

\subsubsection{Płeć kulturowa jako norma}

Płeć kulturowa ma charakter normatywny, wyznacza bowiem „właściwe”, przypisane każdej z płci predyspozycje, zainteresowania i zachowania. „Każde społeczeństwo konstruuje własne reguły bycia kobietą lub mężczyzną, czyli tzw. wzorce $^{2}$ kobiecości i męskości, w ramach których obu płciom stawia się wymagania zarówno pod względem pożądanych cech osobowości, jak i właściwych zachowań w ważnych dla życia zbiorowego dziedzinach" (Sekuła-Kwaśniewicz 2000: 122). W literaturze przedmiotu pojawiają się takie określenia, jak „nor-

\footnotetext{
${ }^{2}$ Pojęcie „wzorca” odpowiada tu zdefiniowanemu wcześniej pojęciu „modelu”.
} 
ma kobiecości i męskości” czy „normy rodzajowe” (Kaschack 1996: 53; Bradley 2008: 27). Stosuje się tu także pojęcie społecznej roli kobiety/mężczyzny czy „roli rodzajowej”, wskazując na jej normatywny charakter. - „Rola męska bądź żeńska stanowi coś $\mathrm{w}$ rodzaju scenariusza, według którego postępują mężczyźni i kobiety, by właściwie odegrać męskość lub kobiecość” (Brannon 2002: 183).

Regulacyjną funkcję gender wobec zachowań jednostki wyjaśnia Ellyn Kaschack, stwierdzając: „Narzucanie norm rodzajowych ma w społeczeństwie zachodnim głównie charakter psychologiczny i jest oparte na niezwykle potężnym mechanizmie upokorzenia, które wywołuje wstyd. Wstyd to jedno z najsilniejszych psychologicznych narzędzi przymusu, zarówno w sferze społecznej, jak $\mathrm{i}$ indywidualnej, manipulujące podstawowym poczuciem szacunku i własnej wartości. [...] Nie pasować do kategorii rodzajowej to sprawa szczególnie wstydliwa, więc psychologia, tak indywidualna, jak i interpersonalna, opiera się na potrzebie dostosowania się" (Kaschack 1996: 53). Szczególnie restrykcyjny jest tradycyjny model płci kulturowej oparty na polaryzacji kobiecości i męskości, wyraźnie je określający i rozgraniczający (patrz kolejny podrozdział). Sandra L. Bem pisze o ,uprzywilejowaniu konformizmu rodzajowego i patologizacji nonkonformizmu rodzajowego", jakie zaobserwować można, według niej, w wielu teoriach psychologicznych (Bem 2000: 116). Zjawisko to występuje także w rzeczywistości społecznej, na co wskazują chociażby wyniki obserwacji sposobu traktowania dziewczynek i chłopców przez rodziców, nauczycieli oraz rówieśników, szczególnie w sytuacji przekraczania przez dzieci granic zachowań przypisanych płci (Lott, Maluso 2002; Gawlicz 2009; Jankowska 2009).

W analizie normatywnego charakteru płci kulturowej podkreśla się znaczenie procesu socjalizacji i internalizacji „upłciowionych” norm przez jednostki oraz kontroli społecznej, jej różnych form, mechanizmów i czynników. W rezultacie większość członków społeczeństwa zachowuje się tak, jak kobieta/ mężczyzna „powinni” się zachowywać. Badacze wskazują na „niezmienność ról płciowych" przyjętych i wyuczonych przez jednostki. Jak zauważa Alex Comfort, ,rola płciowa, przyswojona do drugiego roku życia, okazuje się w rzeczywistości dla większości ludzi niemal niemożliwa do zmiany, nawet jeśli nie zgadza się z fizyczną płcią danej osoby" (Comfort 1963, za: Glover, Kaplan 2007: 13). Spostrzeżenie to potwierdza silny konformizm wobec norm płciowych i trudność w uwolnieniu się od narzuconych etykiet i schematów dotyczących płci, mieszczących się w tradycyjnych konstruktach kobiecości i męskości, opartych na dychotomii płci.

\subsubsection{Stereotypy płci}

Jak stwierdza Kay Deaux, gdy przedmiotem badań jest płeć jako kategoria społeczna, interesuje nas nie to, ,jakie są rzeczywiste różnice pomiędzy kobietami i mężczyznami, lecz to, jak ludzie postrzegają te różnice” (Deaux 1984: 110, 
za: Brannon 2002: 39). Przypomnijmy, za E. Mandal, że Walter Lippman, wprowadzając pojęcie stereotypu do nauk społecznych (1922), ,posłużył się metaforą porównującą stereotyp do zielonej okiennej szyby wystawowej, która pozwala obserwatorowi widzieć jedynie wystawione tam przedmioty i to w określonym, zielonym oświetleniu" (Mandal 2000: 13). Sandra L. Bem w pracy The Lenses of Gender (1993), (w Polsce opublikowanej pod tytułem Messkość, kobiecość. O różnicach wynikajacych z ptci, 2000) proponuje, by przekonania na temat kobiet i mężczyzn, określane przez nią jako „pryzmat rodzaju”, traktować jako soczewki, przez które patrzymy na przedstawicieli obu płci, a które zniekształcają obraz.

Badacze zauważają, że płeć ,jako cecha widoczna, dystynktywna i uniwersalna" jest podstawą wyjątkowo silnej stereotypizacji (Miluska 1996: 75). Płeć i związane z nią przekonania na temat tego, co oznacza bycie kobietą, bycie mężczyzną, ,jest jednym z istotniejszych czynników decydujących o autopercepcji i sposobie postrzegania innych ludzi" (Spence, Sawin 1984; Taylor i in. 1978, za: Miluska 1996: 17). Wyznacza zachowania jednostki oraz zachowania wobec niej innych członków społeczeństwa, wywołuje określone reakcje, oceny itp.

Stereotypy są ,zwykle nadmiernie uproszczone, nadogólne (wszyscy członkowie grupy "są» tacy sami), niepodatne na zmiany w wyniku nowych informacji oraz społecznie podzielane, stanowiąc element kultury jakiejś społeczności" (Wojciszke 2003: 68). Psychologowie społeczni wiążą powstawanie stereotypów z posługiwaniem się przez człowieka schematami w myśleniu i poznawaniu świata - wewnętrznymi strukturami poznawczymi, pomagającymi organizować informacje i kierującymi spostrzeganiem (Miluska 1996: 83; Brannon 2002: 210). Zwracają uwagę na przydatność i funkcjonalność stereotypów w wymiarze społecznym i jednostkowym. Po pierwsze, potwierdzają one obowiązujący w danej kulturze system wartości oraz zapewniają ład społeczny, wyrażając oczekiwania w stosunku do osób o określonej płci (Miluska 1996: 83; Brannon 2002: 212;). Po drugie, dzieląc świat na kobiecy - męski i dostarczając informacji na temat tego, jak jednostka ma się zachowywać jako kobieta/mężczyzna i czego ma oczekiwać od innych, dają jej poczucie bezpieczeństwa i pomagają „zorientować się w sytuacji i dostosować do niej" (Miluska 1996: 83). Do negatywnych skutków stereotypów należą: niedostrzeganie różnic między osobami należącymi do stereotypizowanej grupy, ograniczanie indywidualnego rozwoju człowieka, odporność na zmiany i z związku z tym pozostawanie w sprzeczności z rzeczywistością (Aronson i in. 1997: 544; Brannon 2002: 212; Sekuła-Kwaśniewicz 2000: 123).

Wyróżnić można stereotypy deskryptywne, określające jaki jest, jak się zachowuje, co myśli i czuje członek stereotypizowanej grupy oraz stereotypy normatywne, wskazujące jaki powinien on być (Nelson 2003: 304, 305). Zdaniem niektórych badaczy, stereotypy kobiecości i męskości „są bardziej normatywne niż inne stereotypy”, co wynika z tego, że „na ogół mamy znacznie bogatsze doświadczenia w kontaktach z przedstawicielami drugiej płci niż w relacjach z innymi grupami, co zapewnia większą «bazę danych», z której można czerpać nor- 
matywne «powinności» stanowiące podstawę stereotypów płci" (Fiske, Stevens 1993, za: Nelson 2003: 283).

Według Kay Deaux i Laurie L. Lewis (1984) na stereotypy kobiecości i męskości składają się przekonania dotyczące cech osobowości, ról społecznych, wyglądu zewnętrznego oraz zawodu ${ }^{3}$ (za: Brannon 2002: 219; Mandal 2000: 17-18; 2003: 39). Przy czym „[...] aspekty te są względnie niezależne, ale ludzie przypisują mężczyznom jeden zestaw cech zaczerpniętych z każdej z tych grup, a kobietom - inny. Na podstawie znajomości jednego aspektu dokonują oceny pozostałych trzech" (Brannon 2002: 219). Najistotniejszy wydaje się być wygląd jednostki, dostrzegany w pierwszej kolejności i będący podstawą wnioskowania o jej cechach oraz rodzaju aktywności (Mandal 2000: 19-20). Stereotypy płci opierają się na dychotomii, opozycji właściwości przypisywanych kobietom i mężczyznom. Badania międzykulturowe pokazują z jednej strony bogactwo kulturowych definicji kobiecości i męskości, z drugiej strony - uniwersalizm pewnych przekonań dotyczących jednej i drugiej płci oraz relacji między nimi (Beall 2002: 86; Wojciszke 2003: 418-419; Kimmel 2004: 52; Moore 2005: 313).

Stereotypy kobiecości i męskości pozostają w ścisłym związku z normami płciowymi wyrażającymi się w ,przepisach” ról kobiecych i męskich. Tę wzajemną relację między tymi dwoma aspektami gender można, za Przemysławem Gębalą, ująć w następujący sposób: „Role płciowe wyznaczają zespoły zachowań społecznie pożądanych, a praktyka życia potwierdza wyobrażenia na temat atrybutów kobiecości i męskości. Nie tylko więc stereotypy definiują role, ale też role wzmacniają stereotypy, które w następstwie tego konstytuują koncepcję i sposób percepcji ról płciowych" (Gębala 2007: 14-15).

\subsubsection{Płeć kulturowa jako czynnik stratyfikacji społecznej}

Płeć kulturowa, zarówno jako norma jak i stereotyp, określa „właściwe” kobietom i mężczyznom pozycje i role społeczne oraz podział pracy ze względu na płeć. Przy czym „kobiece” i „męskie” pozycje społeczne wiążą się z różnym dostępem do społecznie cenionych dóbr. Mówi się tu o „społecznych nierównościach płci”, czy „dyskryminacji ze względu na płeć”, co pokazuje, że bycie kobietą/mężczyzną jest jednym z kluczowych czynników, mających wpływ na usytuowanie jednostki w społecznej hierarchii oraz jej możliwości funkcjonowania w różnych sferach życia społecznego. Jak stwierdza J.H. Turner, „[...] od kiedy jakieś dwanaście do osiemnastu tysięcy lat temu ludzie porzucili zbieractwo i łowiectwo, stratyfikacja płci istnieje we wszystkich znanych nam społeczenstwach. System ten faworyzuje mężczyzn, którzy znacznie częściej zajmują takie pozycje i wykonują tego rodzaju role, które dają im najwięcej władzy, bogactwa

${ }^{3}$ Treści stereotypów kobiecości i męskości zostaną przedstawione w kolejnym podrozdziale, poświęconym polaryzacji płci. 
i prestiżu" (Turner J.H. 1998: 126). Zdaniem Sandry L. Bem, podtrzymywaniu męskiej dominacji służą wspominane wcześniej pryzmaty rodzaju (Bem 2000: 16-17). Według niej możemy mówić o trzech takich „soczewkach kultury” determinujących sposób postrzegania kobiecości i męskości. Po pierwsze, androcentryzm, „czyli stawianie pierwiastka męskiego w centrum uwagi”, traktowanie mężczyzn jako płci z natury dominującej i „lepszej” (tamże: 15, 16). Po drugie, polaryzacja płci - przekonanie o odmienności płci, odnoszące się do cech i zachowań, przy czym, jak zaznacza autorka, ,nie chodzi o prymitywne spostrzeżenie, że mężczyźni w zasadniczy sposób różnią się od kobiet, ale o bardziej subtelne i podstępne użycie tej różnicy jako naczelnej zasady organizującej życie społeczne w danej kulturze” (tamże: 16). Po trzecie, esencjalizm biologiczny, „racjonalizujący i uzasadniający poprzednie dwa pryzmaty przez traktowanie ich jako naturalnej i nieuniknionej konsekwencji wewnętrznej, biologicznej natury kobiet i mężczyzn" (tamże). Te trzy przekonania dotyczące kobiecości i męskości oraz relacji między nimi, przyswajane przez jednostki w procesie socjalizacji, leżą u podstaw patriarchalnego systemu społecznego i nierówności płci, warunkując tym samym określone życiowe szanse kobiet i mężczyzn.

W naukach społecznych powstało wiele teorii wyjaśniających nierówności płci. Podstawową wzbudzającą kontrowersje kwestią jest pytanie, czy nierówności płci są trwałym i funkcjonalnym elementem porządku społecznego. Funkcjonalna teoria stratyfikacji społecznej Talcotta Parsonsa uważa nierówności społeczne za zjawisko odwieczne, nieusuwalne, a co więcej, niezbędne dla istnienia i funkcjonowania społeczeństw ludzkich (Reszke 1991: 164; Sztompka 2002b: 358). Obecność nierówności społecznych, w tym także nierówności płci, była traktowana jako wymóg funkcjonalny systemu. Nierówny dostęp kobiet i mężczyzn do cenionych społecznie zasobów związany jest z „naturalnym” podziałem ról w rodzinie, koniecznym do właściwego jej funkcjonowania (Domański 2002). „Gdy rolą mężczyzny jest utrzymywanie rodziny, to głównym zadaniem kobiety jest socjalizacja dzieci, integracja rodziny i zapewnienie równowagi emocjonalnej jej członkom” (Reszke 1991: 165). Rolą społeczną „,właściwą” kobiecie jest rola żony i matki, co ogranicza jej działalność do sfery prywatnej, a tym samym dostęp do takich dóbr jak władza i niezależność ekonomiczna.

W opozycji do podejścia funkcjonalnego stoją teorie konfliktowe, traktujące nierówności społeczne jako efekt szczególnych warunków historycznych i stosunków władzy oraz zjawisko generujące konflikt społeczny (Sztompka 2002b: 358). Według tego podejścia, „ograniczanie i przezwyciężanie nierówności jest nie tylko możliwe, ale pożądane, stanowi ona bowiem czynnik konfliktorodny, zaburzający i dezorganizujący życie społeczne, mogący nawet prowadzić do destrukcji społeczeństwa" (tamże: 359). Do teorii konfliktu nawiązują teorie feministyczne, „analizujące nierówności związane z płcią kulturową jako jeszcze jedną formę rozwarstwienia rodzącego konflikt" i dążące do ich zniesienia i wprowadzenia rzeczywistej równości kobiet i mężczyzn (Turner J.H. 2004: 265). 
Poszczególne ujęcia teoretyczne problematyki nierówności płci różnią się także we wskazywaniu źródeł i przyczyn powstania i utrzymywania się stratyfikacji związanej z płcią (za: Turner J.H. 2004: 264-281; Reszke 1991). Każda z prób wyjaśnienia fenomenu nierówności płci odsłania inny aspekt organizacji społecznej, ekonomicznej i kulturowej społeczeństw, mogący mieć wpływ na nierówne położenie społeczne kobiet i mężczyzn we współczesnych społeczeństwach. Część ujęć teoretycznych skupia się na czynnikach kulturowych - społecznych definicjach męskości i kobiecości i płci kulturowej (np. Sherry B. Ortner; Michelle Rosaldo; Nancy Chodorow). Inne wiążą występowanie nierówności płci z nierównym udziałem kobiet i mężczyzn w sferze produkcji, pociągającym za sobą nierówny dostęp do jej produktów (np. Peggy Sanday; Rae Lesser Blumberg; Janet S. Chafetz). Trzecią grupę wyjaśnień nierówności płci są stanowiska dostrzegające ich źródło w stosunkach władzy (np. Gerhard Lenski; Randall Collins; J. Turner i D. Musick).

\subsubsection{Płeć kulturowa jako właściwość życia społecznego, ujawniająca się w różnych instytucjach społecznych (gendered society)}

Ulrich Beck określa płeć jako „wszechobecną” (Bradley 2008: 17) - relacje między płciami nie ograniczają się do seksualności, małżeństwa, czy rodzicielstwa, ale ujawniają się także $\mathrm{w}$ innych sferach życia społecznego, takich jak „praca, zawód, nierówność, polityka, ekonomia” (Beck 2002: 151). Jak stwierdza H. Bradley, „badania nad płcią można prowadzić w odniesieniu do praktycznie wszystkich fenomenów społecznych i kulturowych" (Bradley 2008: 17). Używa się tu pojęć gendered society, gendered institutions, gendered interactions czy gendered person, wskazując na „upłciowienie” społeczeństwa i różnych jego aspektów czy wręcz „zdominowanie świata społecznego przez system rodzajowy" (Kaschack 1996; Hearn 2003; Kimmel 2004; Wharton 2005; Bradley 2008). Jak zauważa Karolina Krasuska, thumaczka pracy Judith Butler Uwikłani w płeć, używanie imiesłowu biernego gendered, w języku polskim tłumaczonego jako „upłciowiony, określony bądź nacechowany ze względu na kulturową płeć”, sugeruje, że „nic nie «jest» takie, jakim się wydaje, lecz zostało dopiero takim uczynione" (Krasuska 2008: 268). Kulturowe definicje kobiecości i męskości, postrzeganych i określanych jako różne, przenikają różne zjawiska społeczne, które nie są „neutralne płciowo” - płeć jednostek w nich uczestniczących odgrywa istotną rolę, determinuje ich pozycję, sposób ich zachowania i traktowania przez innych, decyduje o dostępie do społecznie cenionych dóbr. Według Joan Acker, „stwierdzenie, że organizacja lub jakakolwiek inna jednostka, którą badamy, jest upłciowiona, oznacza, że korzyści i straty, sposób eksploatacji i kontroli, działania i emocje, znaczenie i tożsamość są w niej modelowane przez różnicę i w kategoriach różnicy między tym, co męskie, i tym, co kobiece" (Acker 1990: 146, za: 
Bradley 2008: 37). Autorka wskazywała, że na proces upłciawiania organizacji składają się cztery następujące zjawiska: 1) tworzenie podziałów między kobietami i mężczyznami; 2) tworzenie symboli i obrazów, wyrażających, uzasadniających i podtrzymujących te podziały; 3) potwierdzające je procesy interakcji; 4) procesy o charakterze mentalnym, świadomościowym związane z definiowaniem siebie przez kobiety i mężczyzn jako jednostki i członków danej organizacji (Acker 1990, za: Bradley 2008: 129; Kimmel 2004: 104). Za H. Bradley można wskazać trzy poziomy życia społecznego, na których zachodzi proces upłciawiania, utrwalania różnic i nierówności między płciami (Bradley 2008: 37-39). Pierwszy to poziom jednostkowych działań i interakcji, drugi - poziom instytucji i instytucjonalnych reguł, trzeci - „makropoziom” - dotyczy szerszych struktur społecznych (tamże).

Badacze analizują zjawisko genderyzacji w takich wymiarach życia społecznego, jak m.in.: stosunki władzy, państwo i polityka, podział pracy, konsumpcja, seksualność i prokreacja, rodzina, relacje emocjonalne (kateksja), kultura (religia, nauka, edukacja, komunikacja, przekazy symboliczne w mediach) (Bradley 2008; Connell 2013; Giddens 2004; Kimmel 2004; Wharton 2005).

\subsubsection{Pleć kulturowa jako wymiar kultury}

Ostatnie ujęcie kategorii gender w perspektywie społecznej: gender jako wymiar kultury, nawiązuje do wcześniej omawianych ujęć, wiąże je ze sobą. Związek płci kulturowej z kulturą danego społeczeństwa wydaje się oczywisty - to w ramach określonej kultury przyjmuje się takie a nie inne koncepcje kobiecości i męskości, stereotypy płci oraz normatywne reguły bycia kobietą i mężczyzną, wyznaczające pozycje społeczne jednostek oraz ich funkcjonowanie w różnych obszarach życia społecznego. Proces uczenia się ról płciowych stanowi element procesu socjalizacji, rozumianego jako poznawanie i przyswajanie kultury społeczeństwa, do którego należymy.

Analiza kobiecości i męskości w perspektywie kulturowej może jednak oznaczać próbę zastosowania tych kategorii do opisu kultury jako kobiecej bądź męskiej, w zależności od tego, czy cenione są w niej wyżej kobiece czy męskie atrybuty. J. Miluska oraz P. Boski proponują następującą definicję takiej typologii kultury: , ,...] kultura jest [...] tym bardziej kobieca, im bardziej bycie kobietą jest samo w sobie wartością oraz im bardziej kobiecy punkt widzenia na to co ważne i godne dążenia staje się powszechnie przyjętym standardem, tak w jednostkowym życiu, jak i w instytucjonalnych rozwiązaniach danego społeczeństwa. Definicja kultury męskiej jest odwróceniem powyższego sformułowania: bycie mężczyzną i atrybuty męskości stają się wówczas przedmiotem szczególnie pozytywnego wartościowania" (Miluska, Boski 1999: 14). Męskość i kobiecość ma tu charakter aksjonormatywny i wpływa na takie inne elementy kultury, jak kultura symboliczna (rozwój sztuki, cenienie wartości estetycznych jako cechy 
kultury kobiecej; ograniczenie znaczenia sztuki w kulturach męskich, koncentrujących się na aktywności ekonomicznej i militarnej), religia i ideologie, czy rozwiązania prawnoinstytucjonalne (gwarancja równości płci versus przywileje dla jednej z płci) (tamże: 15-19).

Jak zauważył P. Boski, stosowanie kategorii kobiece - męskie w analizie kultury można zaobserwować m.in. w religioznawstwie (charakterystyka religii jako męskiej lub kobiecej, w zależności od przyjętej koncepcji Boga) czy antropologii kulturowej (analiza struktury rodziny ze względu na linię dziedziczenia, stosunki władzy, czy miejsce zamieszkania - przy rodzinie żony lub męża) (Boski 1999: 71-72). Kluczowe znaczenie dla koncepcji kobiecości i męskości jako wymiaru kultury mają jednak badania $w$ ramach psychologii międzykulturowej, oparte na analizie systemów wartości społeczeństw. Sztandarowym przykładem są tu bada-

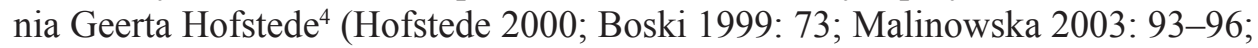
Arcimowicz 2003: 100). Badacz odwołuje się do antropologicznej koncepcji, mówiącej o tym, że społeczeństwa, zarówno tradycyjne, jak i współczesne muszą się zmierzyć z podobnymi problemami i dylematami i różnią się między sobą sposobami ich rozwiązania (Hofstede 2000: 49). Do takich uniwersalnych zagadnień, „znaczących zarówno dla funkcjonowania całych społeczeństw, tworzących je grup, jak i jednostek w obrębie tych grup", ustalonych przez Alexa Inkelesa oraz Daniela Levinsona (1969), należy m.in. koncepcja kobiecości i męskości (Hofstede 2000: 50). Znaczenie wyobrażeń dotyczących płci oraz ,społecznych implikacji urodzenia się chłopcem lub dziewczynką" potwierdziły międzykulturowe badania wartości prowadzone przez G. Hofstede wśród pracowników firmy IBM w różnych krajach (tamże). Autor wykazał, że w odniesieniu do wspomnianego problemu w poszczególnych kulturach narodowych można wyodrębnić wymiar kobiecości - męskości (tamże: 51). Mamy zatem do czynienia z kulturami „męskimi” i „kobiecymi” w zależności od tego, czy w formułowaniu ról płciowych opierają się one na polaryzacji płci, oraz od tego, jakie cechy i postawy są w nich wysoko cenione.

Na podstawie wyników badań G. Hofstede określa kobiecość i męskość jako wymiary kultury w następujący sposób: „«Męskość» to cecha społeczeństw, w których role społeczne związane z płcią są klarownie określone, to znaczy od mężczyzn oczekuje się asertywności, twardości i nakierowania na sukces materialny, natomiast od kobiet skromności, czułości i troskliwości o jakość życia. «Kobiecość» charakteryzuje te społeczeństwa, w których role społeczne obu płci wzajemnie się przenikają, to znaczy zarówno od mężczyzn, jak i od kobiet oczekuje się skromności, czułości i troski o jakość życia" (tamże: 140). Kultury

${ }^{4}$ Jak stwierdza P. Boski, „określanie kultur mianem kobiecych bądź męskich nie jest częste w literaturze nauk społecznych; dlatego też próba Hofstede musi przyciągać uwagę" (Boski 2009: 101). 
męskie i kobiece różnią się m.in. poziomem tolerancji w sprawach obyczajowych, przywiązywaniem wagi do takich kwestii, jak wolność, sprawiedliwość, jakość życia, stosunkiem do środowiska naturalnego, uczestnictwem kobiet i mężczyzn w strukturach władzy, wydatkami na opiekę społeczną oraz wojsko (Boski 1999: 75; Malinowska 2003: 96-97).

W ujęciu tym pojęcia kobiecości i męskości odnoszone do tej pory do jednostek, znajdują zastosowanie w opisie i badaniu kultury (organizacyjnej, ale także narodowej).

\subsubsection{Wymiar jednostkowy}

W perspektywie indywidualnej przedmiotem zainteresowania jest realizowanie, ,przeżywanie” własnej płciowości przez jednostkę. Wszyscy jesteśmy niejako „naznaczeni płcią" - gendered person (Wharton 2005). Płeć można traktować jako „żywe”, „osobiste” doświadczenie (Kaschack 1996: 57; Moore 2005: 335-336; Bradley 2008: 16; Connell 2013: 161). Fakt bycia kobietą/mężczyzną ma znaczenie właściwie dla każdego aspektu życia człowieka - wyglądu, stylu życia, pracy zawodowej, relacji z innymi ludźmi. $Z$ jednej strony odmienne pozycje i role społeczne „wpisane” w kulturowe definicje płci decydują o odmienności doświadczeń kobiet i mężczyzn, z drugiej - indywidualne cechy powodują różnice w odczuwaniu i realizowaniu kobiecości/męskości w ramach każdej z kategorii płci. Stąd postuluje się, by mówić raczej o „kobiecościach” i „męskościach”, obejmujących różne sposoby bycia mężczyzn i kobiet (Connell 1995, za: Kluczyńska 2009: 112; Glover, Kaplan 2007: 19). Przedmiotem zainteresowania jest tu gender nie jako „obiektywny fakt”, ale jako zjawisko doświadczane i przeżywane subiektywnie, któremu jednostka nadaje określone znaczenie, definiuje i interpretuje.

Jednostkowy wymiar płci kulturowej obejmuje własną koncepcję siebie jako osoby o określonej płci. Bycie kobietą i mężczyzną i w związku z tym przejawianie określonych kulturowo predyspozycji, cech, zainteresowań itp. stanowi jedną z ważniejszych płaszczyzn samoidentyfikacji. Jak zauważa Eugenia Mandal, „,hociaż większość ludzi nie potrafi zdefiniować męskości i kobiecości, to równocześnie jest intuicyjnie pewna swojej własnej (zwykle stuprocentowej w ich odczuciu) męskości lub kobiecości” (Mandal 2005: 38). W odniesieniu do tego indywidualnego wymiaru płci używa się określenia „tożsamość płciowa” (gender identity). Zdaniem psychologów, składa się na nią, po pierwsze, przekonanie danej osoby o byciu kobietą/mężczyzną, wyrażające się na przykład w odpowiedzi na pytanie o płeć w kwestionariuszu (Hoyenga, Hoyenga 1979: 4-5, za: Gontarczyk 1995: 42). Po drugie, dostrzeganie u siebie cech psychicznych uznawanych w danej kulturze za typowe dla własnej płci biologicznej (Stojanowska 2008: 135, 136). Warto jednak zauważyć, że możliwe i częste są przypadki (o czym świadczą wyniki badań z wykorzystaniem Inwentarza do Badania Płci Psychologicznej autorstwa Sandry Bem), że jednostki nie utożsamiają się z cechami, które stereotypowo im 
się przypisuje ze względu na płeć. Jak stwierdza Elżbieta Pakszys, „,indywidualna, psychiczna tożsamość płci [...] polega m.in. na uzgadnianiu jej jednostkowej postaci z akceptowanym w danej kulturze (oraz najczęściej naukowo zdefiniowanym) stereotypem tego, co męskie, wobec tego, co kobiece" (Pakszys 2000: 62). Za Ellyn Kaschack można mówić o ,personalizacji konstruktu społecznego" (Kaschack 1996: 137). Anna Titkow, na podstawie wyników badań, zauważa, że współcześnie mamy do czynienia $\mathrm{z}$,tyglem” tożsamości kobiet i mężczyzn, z różnorodnością ich odmian, co wynika z tego, że koncepcje siebie jednostek w różnym stopniu pozostają pod wpływem kulturowych definicji kobiecości i męskości „i możliwych kombinacji tych wymiarów" (Titkow 2007: 129-131).

Jolanta Miluska wymienia trzy aspekty samoidentyfikacji kobiet i mężczyzn: obok poczucia tożsamości (poczucie kobiecości i męskości oraz akceptacja własnej płci) i autokoncepcji (przypisywane sobie atrybuty), aspekt behawioralny tożsamości (Miluska 1996: 23). Zauważa, że zdaniem wielu autorów zachowanie jednostki jako kobiety/mężczyzny stanowi podstawowy komponent koncepcji siebie, gdyż „pozostałe komponenty stanowią niewystarczające bądź zawodne miary tożsamości człowieka" i ,to właśnie działanie umożliwia weryfikację treści samoświadomości” (tamże: 34). Na skomplikowaną relację między koncepcją siebie a zachowaniem jednostki w relacji z innymi zwraca uwagę Robert J. Stoller. Proponuje on oddzielenie od siebie ,płci kulturowej jako roli” i „płci kulturowej jako tożsamości”, przekonując, że zachowanie jednostki może nie wyrażać jej własnego obrazu siebie (Stoller 1968, za: Glover, Kaplan 2007: 14). Według autora, ,[...] życie wewnętrzne i życie zewnętrzne mogą znajdować się ze sobą w głębokim konflikcie bądź w żaden sposób się ze sobą nie zgadzać. [...] Płeć kulturowa odgrywana przed innymi jako rola nie musi wcale zdradzać, kim naprawdę ten ktoś czuje się wewnętrznie" (tamże).

Zdaniem S.L. Bem bycie kobietą/mężczyzną ma kluczowe znaczenie dla tożsamości i życia jednostki i wyprzedza pod względem ważności przynależność do innych kategorii społecznych (jak grupa etniczna, klasa społeczna czy kategoria zawodowa), gdyż ,nasza kultura uczy, iż «dychotomia ta ma znaczenie dla właściwie każdego aspektu naszego życia»,, (Bem 1985, za: Lott, Maluso 2002: 113). Jolanta Miluska $z$ kolei stwierdza, że tożsamość płciowa jest nie tylko jedną z ważniejszych, ale także ,prawdopodobnie najbardziej stabilną pośród wszystkich form tożsamości społecznej człowieka" (Miluska 1996: 14). Autorka zastrzega jednak, że jest to stabilność względna, w związku z możliwymi zmianami w zakresie społeczno-kulturowego wymiaru płci (tamże: 15).

Podsumowując, powyższe rozważania pokazują rozmaite obszary badawcze wiążące się z problematyką płci, różne sposoby jej postrzegania i interpretowania. Jak już zostało wspomniane, wyodrębnienie wyżej opisywanych wymiarów płci kulturowej ma charakter analityczny; w rzeczywistości społecznej oraz badawczej nakładają się one na siebie. Życie jednostek przebiega w określonych warunkach społeczno-kulturowych, na ich doświadczenia wpływają wspominane 
normy i stereotypy płci. A zatem, za Jane Collier i Michelle Z. Rosaldo, można stwierdzić, że „każda analiza musi skupiać się zarówno na tym, co ludzie robią, jak i na kulturowych rozumieniach, które warunkują ich działania" (Collier, Rosaldo 1981: 276, za: Moore 2005: 333). Odnosząc zagadnienie płci kulturowej do przyjętej teorii strukturacji oraz koncepcji roli społecznej, przedmiotem zainteresowania czynimy z jednej strony „strukturę", czyli społeczne modele płci, z drugiej strony „działanie”, czyli wzory kobiecości i męskości realizowane przez przedstawicieli wybranej kategorii społecznej.

\subsection{Polaryzacja płci w tradycyjnym modelu kobiecości i męskości}

Zdaniem Margaret Mead ,nie ma kultury, w której uważano by, że nie ma żadnych różnic pomiędzy płciami” (Mead 1949, za: Uliński 2001: 299). Badacze zwracają uwagę, że mimo istnienia „bogatego asortymentu” kulturowych konstrukcji kobiecości i męskości, można wskazać wspólny dla wielu społeczeństw sposób postrzegania kobiet i mężczyzn (Beall 2002: 86; Kimmel 2004: 52; Renzetti, Curran 2005: 89; Moore 2005: 313). Chodzi tu o przeciwstawienie cech, a także ról oraz sfer aktywności uznawanych za kobiece i męskie. Jak stwierdza Elżbieta Pakszys, w tradycyjne postrzeganie świata wpisana jest ,uniwersalna dwupłciowość”, „dymorfizm płci" (Pakszys 2000: 55). W literaturze przedmiotu mówi się o asymetryczności, dualizmie czy polaryzacji płci (Glennon 1982; Bem 2000; Arcimowicz 2003; Głażewska 2004; Pankowska 2005). Najczęściej wyróżnia się następujące trzy główne i uniwersalne rodzaje dychotomii związane z podziałem na „kobiece" i „męskie": sfera prywatna/sfera publiczna, natura/kultura, sfera reprodukcji/ sfera produkcji. U podstaw koncepcji polaryzacji płciowej leży założenie o silnym i jednoznacznym związku pomiędzy płcią biologiczną człowieka i jego psychiką (predyspozycjami intelektualnymi, emocjonalnymi, cechami osobowości) oraz zachowaniami (Miluska 1996: 27; Bem 2000: 84). Idzie za tym przekonanie o „naturalności” i niekwestionowalności podziału na „kobiece” i „męskie”.

Jak wskazują psychologowie, „,kiedy człowiek analizuje tylko dwa elementy - tak jak jest to w wypadku dwóch płci - skłonny jest myśleć o nich w kategoriach przeciwieństw” (Tavris 1992, za: Brannon 2002: 23). Mamy zatem „naturalną” skłonność do dychotomizowania kobiecości i męskości i chcemy widzieć przede wszystkim różnice między nimi, nie dostrzegając podobieństw. Ponadto liczne badania psychologiczne i społeczne wskazujące na odmienność kategorii płci potwierdzają w społecznym mniemaniu jej istnienie i trwałość. Jak stwierdza Linda Brannon, ,[...] opisywanie i komentowanie różnic pomiędzy rodzajami sprzyja ich dalszemu wyolbrzymianiu. Kiedy ludzie wierzą w istnienie znacznych różnic, stają się bardziej skłonni do dokonywania kategoryzacji i do odmiennego traktowania kobiet i mężczyzn" (Brannon 2002: 36). Społeczne przekonania na 
temat kobiecości i męskości jako przeciwieństw upowszechniają i utrwalają nie tylko naukowcy reprezentujący różne dziedziny, ale także religia, system prawny, edukacyjny oraz środki masowego przekazu (Glennon 1982: 157; Bem 2000: 84).

Dychotomiczne, oparte na przeciwieństwach społeczne konstrukty kobiecości i męskości przedstawiają kobiety i mężczyzn jako osoby pochodzące z dwóch różnych światów, ,ulepione z zupełnie innej gliny” (Cross, Markus 2002: 49, za: Siemieńska 2007a: 319). Linda Brannon pisze o „Doktrynie Dwóch Sfer”, opartej na przekonaniu, że „zakresy zainteresowań kobiet i mężczyzn nie pokrywają się ze sobą" (Brannon 2002: 213). Kobiecość i męskość traktuje się jako wzajemnie się wykluczające. „Być mężczyzną oznacza: «nie być jak kobieta», być kobietą oznacza: «nie być jak mężczyzna»" (Bradley 2008: 64). Taki sposób widzenia kobiecości i męskości znajduje wyraz w języku potocznym, w którym funkcjonuje pojęcie „płeć przeciwna”, stosowane do określenia „drugiej” kategorii płci, w stosunku do tej, do której należy dana osoba (Wharton 2005: 18). Jakiekolwiek podobieństwa między osobnikami obu płci, wynikające chociażby z przynależności do gatunku ludzkiego, są ignorowane. Pociąga to za sobą konieczność eliminowania przez jednostkę cech i zachowań określanych jako niezgodne z jej płcią biologiczną i kulturową, a w rezultacie niemożność „bycia sobą”. Jak stwierdza Gayle Rubin, „[...] zamiast wyrażać naturalne różnice, idea wykluczających się tożsamości płciowych ukrywa w efekcie naturalne podobieństwa. Jej konsekwencją jest konieczność wyparcia: w mężczyznach tego wszystkiego, co stanowi lokalną wersję cech «kobiecych»; w kobietach zaś lokalnie definiowanych cech «męskich». Rozdział na dwie płci prowadzi do stłumienia określonych cech osobowości praktycznie u wszystkich, tak mężczyzn, jak kobiet" (Rubin 1975, za: Glover, Kaplan 2007: 15). Zdaniem H. Bradley: ,wszelkie formy kategorii binarnych [...] są same w sobie opresyjne, ponieważ decydują one, co powinniśmy robić, i przez to - co jesteśmy w stanie zrobić" (Bradley 2008: 31-32). W odniesieniu do dychotomii kobiecości i męskości można mówić o systemie opresji płci czy reżimie płci (Wilchins 1997, za: Gawlicz 2009: 93, 116; Connell 2013). Riki A. Wilchins opisuje go za pomocą metafory dwóch klatek, którymi są kategorie płci i wymienia pięć następujących reguł, na których reżim ten się opiera: „1) istnieją tylko dwie klatki; 2) każdy musi być w klatce; 3) nie ma obszaru pośredniego; 4) nie można zmienić klatki; i 5) nie można wybrać sobie klatki" (Wilchins 1997: 156, za: Gawlicz 2009: 93). Ujęcie to podkreśla ograniczający charakter płci kulturowej opartej na polaryzacji, wyznaczającej wyraźne granice tego, co „kobiece” i „męskie” i skazującej na stygmatyzację osoby próbujące je przekraczać.

Badacze podejmujący problematykę polaryzacji płci wskazują następujące wymiary zróżnicowania męskie - kobiece:

- orientacja na sprawczość (działanie) versus wspólnotowość (Bakan 1966, za: Miluska 1996: 75, Wojciszke 2003: 419);

- instrumentalność versus ekspresyjność (Parsons 1955, za: Miluska 1996: 75, Wojciszke 2003: 419); 
- cechy instrumentalne, asertywne versus orientacja interpersonalna (Williams, Best 1982, za: Miluska 1996: 75);

- kompetencja versus ciepło - ekspresyjność (Broverman i in. 1972, za: Miluska 1996: 75);

- dominacja versus ciepło (Lubinski i in. 1983, za: Miluska 1996: 75);

- nastawienie na utrzymanie przewagi nad innymi versus bliskość, wsparcie i porozumienie (Tannen 1999, za: Wojciszke 2003: 419).

W międzykulturowych badaniach nad stereotypami płci, prowadzonych w 30 krajach z różnych części świata, wykazano dużą zbieżność w kojarzeniu określonych cech z kobiecością i męskością (Williams, Best 1990, za: Wojciszke 2003: 418-419). We wszystkich społeczeństwach mężczyznom przypisywano takie cechy, jak: odważny, dominujący, gwałtowny, niezależny, skłonny do przemocy i silny, do kobiecości natomiast odnoszono określenia: czuła, uległa i przesądna (tamże; Brannon 2002: 228).

Jak wspomniano w poprzednim podrozdziale, poza cechami osobowości stereotypy płci obejmują także cechy wyglądu, role społeczne oraz zawód. Badaczki Kay Deaux i Laurie L. Lewis (1984) przedstawiły następujące treści składające się na tradycyjne definicje kobiecości i męskości (za: Mandal 2000: 17-18; 2003: 39):

Tabela 1. Treści stereotypów kobiecości i męskości według K. Deaux i L.L. Lewis

\begin{tabular}{|l|l|l|}
\hline \multicolumn{1}{|c|}{ Określenie } & \multicolumn{1}{|c|}{ Kobiecość } & \multicolumn{1}{c|}{ Męskość } \\
\hline Cechy osobowości & $\begin{array}{l}\text { Emocjonalność, zdolność } \\
\text { do poświęceń, delikatność, } \\
\text { czułość, troska o uczucia innych, } \\
\text { umiejętność rozumienia innych, } \\
\text { ciepło w relacji z innymi, } \\
\text { pomaganie }\end{array}$ & $\begin{array}{l}\text { Niezależność, aktywność, } \\
\text { kompetencja, łatwość } \\
\text { podejmowania decyzji, } \\
\text { niezawodność, wiara w siebie, } \\
\text { nieuleganie naciskowi, poczucie } \\
\text { przywództwa }\end{array}$ \\
\hline Role społeczne & $\begin{array}{l}\text { Wsparcie emocjonalne dla innych, } \\
\text { zarządzanie domem, opieka nad } \\
\text { dziećmi, urządzanie domu }\end{array}$ & $\begin{array}{l}\text { Głowa domu, utrzymywanie } \\
\text { fnansowe rodziny, przywództwo, } \\
\text { domowe naprawy }\end{array}$ \\
\hline Wygląd zewnętrzny & $\begin{array}{l}\text { Delikatny głos, schludność, } \\
\text { wdzięk, miękkość ruchów }\end{array}$ & $\begin{array}{l}\text { Wysoki, silny, krzepki, szeroki } \\
\text { w ramionach }\end{array}$ \\
\hline Zawód & $\begin{array}{l}\text { Terapeutka, telefonistka, } \\
\text { logopeda, nauczycielka w szkole } \\
\text { podstawowej, pielęgniarka }\end{array}$ & $\begin{array}{l}\text { Kierowca ciężarówki, agent } \\
\text { ubezpieczeniowy, instalator } \\
\text { telefonów, chemik, burmistrz } \\
\text { miasta }\end{array}$ \\
\hline
\end{tabular}

Źródło: Deaux i Lewis 1984, za: Mandal 2000: 17-18; 2003: 39.

Inne dziedziny życia, w których dostrzec można podział na „kobiece” i „męskie" to m.in. zainteresowania, sposób spędzania wolnego czasu czy sporty, a także zachowania wobec przedstawicieli odmiennej płci (Deaux, Kite 2002: 361; 
Miluska 1996: 76). A zatem z męskością wiążą się takie formy rekreacji, jak football, boks czy polowanie, oraz opiekuńczość a zarazem zdecydowanie w stosunku do kobiet. Z kolei jako typowe dla kobiet postrzegane jest czytanie romansów, a w relacji z mężczyznami - dbanie o autoprezentację (Miluska 1996: 76). Na opisane wyżej społeczne konstrukty płci składa się także orientacja heteroseksualna. Jak przypomina Michael Flood, „niezależnie od kontekstu, jaki weźmiemy pod uwagę, istnieją $\mathrm{w}$ nim pewne formy gender i seksualności, które są dominujące (kulturowo pochwalane i społecznie usankcjonowane), podczas gdy inne formy są stygmatyzowane, przemilczane bądź karane" (Flood 2008: 265-266). Tradycyjny model płci powiązany jest z heteronormatywnością, co oznacza, że „prawdziwa” kobieta i „prawdziwy” mężczyzna nie mogą być homoseksualni (Miluska 1996: 77; Mandal 2000: 18).

Powyższa prezentacja atrybutów kobiecości i męskości ma charakter weberowskiego typu idealnego, niewystępującego w rzeczywistości w czystej postaci. Jak podkreśla Jolanta Miluska, ,[...] ludzie nie sądzą, że wszystkie kobiety są w równym stopniu delikatne, a wszyscy mężczyźni - dominujący. Grupę kobiet i mężczyzn spostrzega się raczej jako odmienne ze względu na posiadanie różnego średniego poziomu atrybutów" (Miluska 1996: 76). Za Raewyn Connell powinno się raczej mówić o męskościach i kobiecościach, wskazując na różne możliwe sposoby bycia kobietą i mężczyzną, występujące w danym społeczeństwie, charakteryzujące się różnym ,nasyceniem” cech uznawanych za typowe dla danej płci (Connell 1995; 2000, za: Glover, Kaplan 2007: 19; Connell 2013; Kluczyńska 2009: 97). Odwołujemy się wówczas do pojęcia wzoru społecznego - konkretnych zachowań kobiet i mężczyzn, które mniej lub bardziej odbiegają od społecznego modelu kobiecości i męskości. Zdaniem autorki można wskazać na dominujący w danej kulturze, najbardziej rozpowszechniony wzór bycia mężczyzną, który określa ona mianem męskości hegemonialnej (hegemonicznej) (Connell 1987, za: Bradley 2008: 64; Connell 2013; Hyży 2010: 72). We wspó1czesnych zachodnich społeczeństwach odpowiada on opisanemu wyżej tradycyjnemu modelowi płci - ,jest to taka forma męskości, o której mówimy «macho»: mężczyzny twardego, nastawionego na rywalizację, niezależnego, opanowanego, agresywnego i zdecydowanie heteroseksualnego" (Bradley 2008: 64). Zdaniem R. Connell „męskość hegemonialna jest zawsze konstruowana w relacji do różnych podrzędnych typów męskości, a także w relacji do kobiet" (Connell 1987: 183, za: Bradley 2008: 64). Te podrzędne formy męskości obejmują na przykład mężczyzn homoseksualnych, osoby o innym niż biały kolorze skóry czy mężczyzn o bardziej empatycznym i łagodniejszym usposobieniu, zbliżonym do definiowanego jako kobiece (Bradley 2008: 64). Autorka wyraża przekonanie, że w odniesieniu do kobiet nie można wskazać jednej dominującej formy kobiecości we współczesnym społeczeństwie, natomiast da się zauważyć istnienie „«przesadnej kobiecości», która stanowi kontrapunkt dla męskości hegemonialnej i którą charakteryzują cechy przeciwne do tego, co męskie; przesadna kobiecość jest 
typem łagodnym, pokornym, skromnym w sferze seksualnej, powabnym i zalotnym, lubiącym życie rodzinne i troszczącym się o swój wygląd zewnętrzny" (Bradley 2008: 64).

Odwołując się do społecznego przekonania o polaryzacji płci, stworzono pierwszy test psychologiczny służący do oszacowania kobiecości i męskości danej osoby, traktujący je jako „głęboko zakorzenione i odwieczne” aspekty ludzkiej osobowości (Terman, Miles 1936, za: Bem 2000: 102-103). Pozycje w teście dotyczące cech, zainteresowań, preferencji podzielono na „typowo męskie” i „typowo kobiece”, a metoda obliczania punktów (przyznawanie punktów „kobiecych” i „męskich” za odpowiedzi „właściwe” danej płci, a następnie odejmowanie punktów „kobiecych” od punktów „męskich”) „stawiała męskość i kobiecość na dwóch przeciwległych końcach jednej osi” (tamże: 103). Wynik takiego testu określał jednostkę jako albo męską, albo kobiecą, nie przewidując innych możliwości (np. bycia jednocześnie męskim i kobiecym) (tamże). Zdaniem Sandry L. Bem, polaryzacja kobiecości i męskości, na której opierało się omawiane narzędzie, „dała naukową i psychologiczną podbudowę tradycji uznawania, że istnieją dwa, i tylko dwa, wzajemnie wykluczające się scenariusze zachowań męskich i kobiecych” oraz uzasadniała ,zakorzenione w kulturze przekonanie, że osoba może być wyłącznie rodzaju męskiego lub żeńskiego, ale nigdy - mieszanką tych dwóch rodzajów" (Bem 2000: 104).

Antropologowie zwracają uwagę, że wspólne dla wielu kultur jest nie tylko rozróżnianie kobiecości i męskości, ale także wartościujący charakter tego podziału, w którym wyżej cenione są cechy, zachowania i role społeczne przypisywane mężczyznom. Jak już wspomniano, gender stanowi istotny czynnik stratyfikacji, wyznaczając przedstawicielom obu płci nierówny dostęp do społecznie cenionych dóbr. Istniejące społeczeństwa mają charakter patriarchalny. Utrzymują się w nich, w mniejszym lub większym stopniu, nierówności płci, przejawiające się w nierównych szansach kobiet i mężczyzn w rodzinie, edukacji, pracy i sferze publicznej (Inglehart, Norris 2009: 11-12, 173). Jak stwierdził Erich Fromm, „przed sześcioma tysiącami lat patriarchat odniósł zwycięstwo nad kobietą - społeczeństwo zostało oparte na dominacji mężczyzny” (za: Funk 1999: 5). Badacze wskazują, że „nie jest znana kultura, w której kobiety miałyby większą władzę niż mężczyźni”, należy jednak uwzględniać historyczne i kulturowe zróżnicowania form patriarchatu (Giddens 2004: 133). Jeff Hearn wprowadza „koncepcję patriarchatów”, „gdyż w różnym czasie w różnych miejscach istniały różniące się od siebie formy patriarchatu, a także różne jego formy funkcjonują jednocześnie w ramach rozmaitych obszarów społecznych, posiadają odmienny zasięg, rozmiary i trajektorie historyczne" (2008: 251). Sylvia Walby natomiast proponuje, by mówić o zmieniającym się stopniu ,patriarchalności” różnych wymiarów życia społecznego oraz rozróżnia patriarchat prywatny i publiczny (Walby 1990, za: Giddens 2004: 139; Bradley 2008: 61). 
Wyższą pozycję społeczną mężczyzn i podporządkowanie kobiet można traktować jako fakt uniwersalny, powszechny i ponadkulturowy (Ortner 1982: 112, 115; Bourdieu 2004). Zwolennicy esencjalizmu biologicznego przyczyn społecznego upośledzenia kobiet szukali $\mathrm{w}$ różnicach anatomicznych i fizjologicznych między płciami. „Mózg kobiet, mniej rozwinięty w porównaniu z mózgiem mężczyzn, odpowiadać ma za ich mniejszą ogólną inteligencję, a funkcjonalna dominacja pól odpowiedzialnych za rozwój cech «miękkich» czynić ma kobiety istotami prymitywnymi, kierowanymi niepodlegającymi rozumowej kontroli instynktami" (Miluska 1996: 47). (Takie podejście do kobiecości i męskości prezentuje cieszące się dużą popularnością, wielokrotnie wznawiane opracowanie pod znamiennym tytułem Płeć mózgu autorstwa Anne Moir i Davida Jessela). Niższość kobiet wyjaśniano także, odwołując się do socjobiologicznej analizy różnic między płciami, związanych z płodnością i reprodukcją. Edward O. Wilson wskazywał, że kluczowe znaczenie ma fakt, odnoszący się do całego świata zwierząt, także ludzi, że osobniki żeńskie mogą „wyprodukować” ograniczoną liczbę potomstwa, podczas gdy możliwości reprodukcyjne samca są znacznie większe, ,ograniczone jedynie przez liczbę płodnych samic, które zdoła zapłodnić" (Wilson 1978, za: Bem 2000: 28). Z tych różnic wynikają, zdaniem socjobiologów, różnice w usposobieniu i zachowaniu przedstawicieli obu płci. Mężczyzn dążących do zmaksymalizowania reprodukcji własnych genów cechuje rozwiązłość seksualna oraz agresja wobec innych osobników męskich, a także niewiernych partnerek oraz pasierbów. Wyjaśniano, że „mężczyźni powszechnie dominują nad kobietami, ponieważ przyjęte przez nich strategie rozrodcze upoważniają ich do tego" (Bem 2000: 30). W charakterystyce kobiet wskazywano ich ,nieśmiałość i wstrzymywanie się od kontaktów seksualnych, staranny dobór partnerów seksualnych, zaangażowanie czasu $\mathrm{i}$ energii $\mathrm{w}$ roztoczenie opieki nad potomstwem, preferowanie monogamii oraz oszukiwanie partnerów w kwestii ojcostwa" (tamże: 29).

Sherry B. Ortner w poszukiwaniu przyczyny przekonania o niższości kobiet odrzuca biologiczny determinizm, stwierdzając, że problem leży w kojarzeniu kobiecości z naturą, a męskości z kulturą (Ortner 1982: 119). „Istotą kultury ma być panowanie nad naturą, a nawet jej przekraczanie, a wobec tego poddaństwo (jeżeli nie wręcz ucisk) kobiet jest zjawiskiem oczywistym" (tamże). Zdaniem autorki, postrzeganie kobiet jako bliższych naturze wiąże się z fizjologią kobiecego ciała, zaangażowanego bardziej niż ciało mężczyzny w reprodukcję gatunku. Mężczyźni, pozbawieni tych „naturalnych funkcji kreatywnych”, wykazują się „twórczością zewnętrzną, «sztuczną», dokonywaną przez technikę i symbole”, której rezultaty są , względnie trwałe, wieczne i transcendentne, kobieta natomiast produkuje innych śmiertelników” (tamże: 122). Ponadto, ze względu na to „większe uwikłanie" kobiecego organizmu w funkcje rozrodcze i związaną z karmieniem opiekę nad małym dzieckiem, aktywność społeczna kobiet jest ograniczona w porównaniu z aktywnością mężczyzn i przypisana do sfery domowo-rodzinnej, postrzeganej jako bliższa naturze i niecieszącej się społecznym prestiżem (tamże: 
124-125, 127). „Mężczyznom brak «naturalnej» podstawy (karmienia, uogólnionego na całą opiekę nad dzieckiem) do orientacji domatorskiej, przeznacza się ich zatem do działalności w sferze pozarodzinnej. Są więc «naturalnymi» gospodarzami religii, rytuału, polityki i innych dziedzin, w których dokonuje się synteza duchowa i społeczna. Mężczyzn utożsamia się nie tylko z kulturą, rozumianą jako wszelka ludzka aktywność wykraczająca poza naturę; są oni w szczególności identyfikowani z kulturą $\mathrm{w}$ tradycyjnym sensie - z tak wyrafinowanymi aspektami ludzkiego myślenia, jak sztuka, religia, prawo itd." (tamże: 127). Wreszcie, S.B. Ortner pokazuje, że w społecznym przekonaniu także określone właściwości psychiczne kobiet, jakie przejawiają one $\mathrm{w}$ związku z pełnionymi rolami matek i opiekunek, potwierdzają ich „bliskie więzi z naturą” (tamże 129-130). Autorka w swym opracowaniu odsłania logikę rozumowania stojącą za powszechną deprecjacją kobiet, pokazując tym samym siłę „kulturowych ideologii” i symbolicznych skojarzeń, nakładanych na kategorie „kobieta” i „mężczyzna” (Moore 2005: 313).

Asymetryczną relację płci, w której jedna ze stron (mężczyźni) jest uprzywilejowana i ma pozycję dominującą, a drugą ze stron (kobiety) cechuje podporządkowanie i ograniczony dostęp do społecznie cenionych dóbr, można opisywać w kategoriach konfliktu (Titkow i in. 2004b). Jak stwierdza Jean Baker Miller, „to oczywiste, że nierówność prowadzi do konfliktu” (Baker Miller 1986: 9, za: Titkow i in. 2004b: 77). Jak zauważają jednak Anna Titkow, Bogusława Budrowska i Danuta Duch, o realnym konflikcie społecznym można mówić dopiero gdy układ nierówności traci społeczną legitymizację, zostaje zakwestionowany (Titkow $i$ in. 2004b: 78, 83). Tymczasem konflikt płci pozostaje nieujawniony, ukryty, gdyż obie strony, a przede wszystkim kobiety jako ,poszkodowane” w tej relacji, akceptują istniejący porządek społeczny (tamże: 76). Stąd, mimo widocznego, chociażby w opozycji kobiece - męskie, antagonizowania płci, w odniesieniu do patriarchalnego układu społecznego stosuje się pojęcie „kontraktu płci”, zakładające obopólną zgodę na nierówny status tworzących go stron i jego społeczne uprawomocnienie. Jak stwierdzają autorki, ,[...] aby utrudnić określenie się kobiet w kategorii grupy interesu, a co za tym idzie zapobiec przekształceniu ukrytego konfliktu między płciami w konflikt otwarty, kultura patriarchalna wypracowała mechanizmy symbolicznego rozwiązywania konfliktów pomiędzy kobietami i mężczyznami. Symbolika owych rozwiązań polega na tym, że niekorzystna dla kobiet relacja między płciami jest niedostrzegana, a nawet gdy jest dostrzegana, nie jest definiowana w kategoriach konfliktu" (tamże: 100). Do tych strategii eliminujących czy osłabiających konflikt płci należą m.in. przekonywanie o „naturalnej odmienności" kobiet i mężczyzn, predestynujących ich do innych zadań i rodzajów aktywności, oraz o „funkcjonalności” podziału ról ze względu na płeć czy zaprzeczanie istnienia dyskryminacji kobiet (tamże: 100-110). W rezultacie nie dochodzi do delegitymizacji społecznej tradycyjnego porządku i jest on odtwarzany przez kolejne pokolenia kobiet i mężczyzn. 
Badacze, wyjaśniając trwałość tradycyjnego modelu kobiecości i męskości opartego na polaryzacji i asymetrii płci, reprodukowanego w codziennych praktykach, wskazują, że ,stereotypizacja pełni użyteczną funkcję podtrzymywania nierówności" (Fiske 1993, za: Nelson 2003: 282). Dominacja mężczyzn z jednej strony ma swoje źródło w społecznych przekonaniach potwierdzających ich wyższość nad kobietami, z drugiej strony pozwala na podtrzymywanie owych przekonań legitymizujących istniejące nierówności płci. Jak stwierdza Todd D. Nelson, „,...] ci, którzy mają władzę (czyli mężczyźni), przyjmują ideologie (między innymi stereotypy płci) i przekonania uzasadniające ich dominację nad słabszą grupą (to jest nad kobietami). Owe ideologie przyczyniają się do umacniania ucisku słabszej grupy oraz osłabiają konflikty międzygrupowe przez instytucjonalizację tych ideologii w społeczeństwie" (Nelson 2003: 283). Postawę akceptacji własnego podrzędnego statusu społecznego przez kobiety Catherine Hakim określiła jako paradoks zadowolonego niewolnika (Hakim 1991, za: Domański 1992: 138). Powstanie tego syndromu można wyjaśnić z jednej strony poprzez odwołanie do procesu socjalizacji, przygotowującego kobiety do czerpania satysfakcji z zajmowanych przez nie pozycji społecznych. $Z$ drugiej strony może to być wyraz fatalizmu kobiet - przekonania, że asymetria płci jest czymś nieuchronnym i niezmiennym, a zatem trzeba ją zaakceptować, bo „inaczej być nie może”.

Podsumowując, tradycyjny model płci opiera się na następujących założeniach:

a) kobiecość i męskość to dwie zupełnie różne, przeciwstawne sobie kategorie;

b) różnice płci są naturalne (przekonanie o biologicznym determinizmie);

c) podział na „kobiece” i ,męskie” jest wartościujący i pociąga za sobą społeczne nierówności płci, postrzegane jako naturalne i funkcjonalne;

d) „reżim płci” nie pozostawia jednostce wyboru, jeżeli chodzi o kształtowanie własnej tożsamości i drogi życiowej;

e) z normami płci wiążą się normy heteroseksualności;

f) polaryzacja płci i nierówny status kobiet i mężczyzn prowadzi do przekonania o antagonizmie między płciami (,,walka płci”, ,,konflikt płci”).

\subsection{Macierzyństwo i ojcostwo w tradycyjnym modelu kobiecości i męskości}

Z polaryzacją płci wiąże się polaryzacja ról rodzicielskich. Matki kojarzone są z „miękkimi” cechami, miłością, ciepłem itp. (stereotyp „matczynej łagodności”), podczas gdy w męskość wpisany jest chłód emocjonalny, a postać ojca jawi się jako surowa, chłodna, władcza (stereotyp „twardej ojcowskiej ręki”). Według teorii funkcjonalnej matki pełnią w rodzinie role „ekspresyjno-integracyjne”, czyli odpowiadają za zapewnianie dzieciom opieki i bezpieczeństwa, zaspokojenie 
ich potrzeb emocjonalnych oraz socjalizację (Parsons 1969: 77; 1972: 550; Glennon 1982: 152; Giddens 2004: 134; Renzetti, Curran 2005: 240). Ojcom przypadają zadania ,instrumentalno-przystosowawcze”, wiążące się ze zdobywaniem środków na utrzymanie rodziny. Powyższy podział rodzicielskich funkcji między matkę i ojca uzasadniany jest, z jednej strony, większym „zaangażowaniem” kobiet $\mathrm{w}$ proces prokreacji (ciąża, poród, karmienie piersią), z drugiej zaś, różnymi przypisywanymi kobietom i mężczyznom cechami, predyspozycjami itd. Zdaniem funkcjonalistów taka rodzicielska specjalizacja po pierwsze, ma uniwersalny i naturalny charakter, po drugie - jest konieczna dla prawidłowego funkcjonowania rodziny (tamże).

Zdaniem psychologów ewolucyjnych przyczyną nierównego udziału kobiet i mężczyzn w opiece nad potomstwem jest niepewność ojcostwa. „Matka ma stuprocentową pewność, że przekazuje potomstwu swoje własne geny, bo to ona rodzi. [...]. Nie ulega wątpliwości, że potomstwo kobiety będzie nosiło $50 \%$ jej genów. Samiec niestety nigdy nie może być pewien swojego ojcostwa. Nie może wykluczyć, że to jakiś inny samiec zapłodnił samicę. [...]. Efektem niepewności ojcostwa są między innymi mniejsze inwestycje w dzieci ze strony ojców" (Szlendak 2010: 47-48). Według teorii pradawnego matriarchatu Johanna J. Bachofena w najwcześniejszych formach społeczeństwa nie znano w ogóle instytucji ojcostwa, gdyż ludzie żyli w bezładzie płciowym (promiskuityzm) - , wszystkie kobiety współżyły ze wszystkimi mężczyznami” (tamże: 302). Pierwotne hordy miały charakter matriarchalny, w których „władza w rodzinie, społeczna i polityczna należała do kobiet"'5 (Krzak 2007: 13). To one jednak były obciążone opieką nad potomstwem, z której zwolnieni byli mężczyźni - nie znano bowiem instytucji ojca. Prymitywną formą małżeństwa, pozwalającą na „ustalenie ojcostwa” była poligynia, która, zdaniem Fryderyka Engelsa, pojawiła się jako system tworzenia rodziny po pierwotnym promiskuityzmie (Engels 1949, za: Szlendak 2010: 123, 304). Według J.J. Bachofena to same kobiety doprowadziły do powstania monogamicznej rodziny, by niejako nałożyć na mężczyzn zobowiązania wobec dzieci (Szlendak 2010: 302). Z drugiej strony, można spotkać się z koncepcjami, zgodnie z którymi to mężczyźni dążyli do instytucjonalizacji związku z kobietą, by uchronić się od owej niepewności ojcostwa (O’Brien 1982, za: Humm 1993: 149). „Dopiero małżeństwo usankcjonowało ojcostwo, które w ten właśnie sposób udało się ustalić. Tak właśnie powstało prawo ojcowskie i w konsekwencji patriarchat zastąpił pierwotny matriarchat" (Szlendak 2010: 302-303). Jak podaje Tomasz Szlendak, badania antropologiczne obaliły twierdzenia J. J. Bachofena i innych

\footnotetext{
${ }^{5}$ Maria Ciechomska zauważa, że raczej powinno się mówić o „matrocentryzmie” pierwotnych wspólnot, a przynajmniej nie utożsamiać matriarchatu z , , [...] czymś w rodzaju patriarchatu do góry nogami. Etymologicznie bowiem matriarchat oznacza nie «rządy matek», lecz «na początku matka» (od greckiego arche, początek). Poza tym w epoce kamiennej nie istniała jeszcze żadna władza w znaczeniu instancji centralnej kierującej losami grupy" (Ciechomska 1996: 11).
} 
dziewiętnastowiecznych ewolucjonistów o istnieniu promiskuityzmu i poligamii w pierwotnych społecznościach (tamże: 305-306). To, co nie ulega wątpliwości, to fakt istnienia matriarchalnych religii, w których obiektem kultu były przede wszystkim funkcje prokreacyjne kobiet, „dawanie życia” (Krzak 2007: 139-140). Magna Mater - Wielka Matka była najwcześniejszym bogiem w historii ludzkości, czczono ją już około 30 tys. lat temu (tamże: 137). „Dominująca pozycja kobiecego bóstwa i kobiety została zakwestionowana ponoć wtedy dopiero, gdy odkryto udział mężczyzny w zapłodnieniu. W czasach matriarchatu sądzono, że matka sama w sobie dysponuje wystarczającą mocą, aby stworzyć nowe życie" (Eichelberger 1997: 70). Koncepcja pradawnego matriarchatu pokazuje problematyczność ojcostwa, które nigdy nie jest tak „oczywiste” jak macierzyństwo.

W tradycyjnych kulturowych definicjach kobiecości i męskości rola rodzicielska ma inne miejsce i znaczenie w przypisanym kobietom i mężczyznom repertuarze ról społecznych. W przypadku kobiet potwierdza się „freudowska prawda", że anatomia to przeznaczenie: budowa ciała i fizjologia wyznacza ,właściwą" im rolę i płaszczyznę aktywności ${ }^{6}$. Obowiązuje je „nakaz macierzyństwa”, traktowanego jako centralny, nieodłączny i dominujący element kobiecości. „Dorosła kobieta, to z definicji taka, która ma dzieci, która jest matką" (Russo 1976: 144, za: Budrowska 2000: 13). Rodzenie i wychowywanie dzieci uznaje się za podstawowe zadanie, powinność i cel życia kobiet, bez względu na różniące je cechy wyglądu i osobowości, ich różne zainteresowania, uzdolnienia, wykształcenie, zawód, poziom zamożności itp. (Budrowska 2003: 58). Sally Macintyre, demaskująca „oficjalną doktrynę reprodukcji”, zwraca uwagę na powszechną społeczną wiarę w „nieświadomy pociąg do macierzyństwa”, czy „popęd macierzyński” kobiet (Macintyre 1982: 196). W społecznym dyskursie mówi się o ich „naturalnym powołaniu” oraz „wrodzonym instynkcie macierzyńskim” (Budrowska 2001: 17). Niechęć do posiadania dzieci jest traktowana jako odstępstwo od normy, dewiacja, przejaw niedojrzałości jednostki czy nawet jej „niekobiecości”. Na byciu matką opiera się tożsamość kobiety i jej samoocena, zatem bezpłodność i w związku z tym niemożność spełnienia społecznych oczekiwań prowadzi do jej poczucia niespełnienia, bycia niepełnowartościową i gorszą (Budrowska 2000; Bartosz 2002; Kalus 2002; Garncarek 2010).

Przypisywany kobietom instynkt macierzyński oznacza nie tylko chęć posiadania dziecka przez każdą kobietę, ale także wrodzone, naturalne umiejętności do sprawowania opieki nad nim. „W naszych oczach każda kobieta, stając się matką, znajduje w sobie wszelkie odpowiedzi na zadania stawiane jej przez nową

${ }^{6}$ Jak komentuje myśl Z. Freuda E. Kaschack: „Freud miał rację zauważając, że anatomia to przeznaczenie, lecz mylił się wyjaśniając to zjawisko fallocentrycznie i redukcjonistycznie. Przeznaczenie nie leży w biologicznie zdeterminowanej anatomii, lecz w anatomii podporządkowanej pojęciu rodzaju i umieszczonej w znaczącym kontekście. Anatomia jest przeznaczeniem, bo takie znaczenie nadało jej społeczeństwo" (Kaschack 1996: 55). 
sytuację. Zupełnie tak, jakby jakieś siły preegzystencjalne, działające automatycznie i w sposób konieczny, czekały tylko okazji, aby się ujawnić. Ponieważ prokreacja jest aktem naturalnym, wyobrażamy sobie, że biologicznemu i fizjologicznemu zjawisku ciąży musi odpowiadać z góry określona postawa macierzyńska" (Badinter 1998: 15). Prowadzi to do przekonania, że jedynie matka jest w stanie dobrze zająć się swoim dzieckiem, a ojciec może ją w opiece nad potomstwem co najwyżej wspierać. W rezultacie w przypadku rozwodu to kobieta zostaje główną opiekunką dziecka, mężczyzna ,starając się o prawo opieki nad dziećmi, zwykle przegrywa z matką, nawet jeśli jej postawa wobec dzieci budzi wiele zastrzeżeń" (Piątek 2007: 98).

Zdaniem Bogusławy Budrowskiej, rekonstruującej tradycyjny, stereotypowy obraz macierzyństwa, jego centralnym punktem jest zasada: „dziecko jest najważniejsze" (Budrowska 2001: 107). Podporządkowanie się jej oznacza zejście na dalszy plan, czy nawet unieważnienie, potrzeb, planów, celów kobiety: „Dobro jej dzieci jest jej dobrem, jej pragnienia zredukowane są do szczęścia dzieci” (tamże: 110). Macierzyństwo prowadzi do wyrzeczenia się przez kobiety ich seksualności, czyniąc z ich istoty aseksualne. Zmysłowość kobiet i ich zmysłowe potrzeby nie mieszczą się bowiem w wizerunku „,czystej” matki, „matki ideału”, „matki anioła" (tamże: 112). Poza tym, pożycie płciowe ma służyć reprodukcji, a nie zaspokajaniu popędu seksualnego, przynajmniej w przypadku kobiet.

Od matki wymaga się pełnego poświęcenia i stałej obecności przy dziecku: „Dobra matka jest z nim nierozłączna” (tamże: 107). To na kobiecie spoczywa „całkowita odpowiedzialność za rozwój dziecka, jego zdrowie fizyczne i psychiczne, wygląd, zachowanie itp." (tamże). Przyczyn różnego rodzaju chorób, zaburzeń w rozwoju czy dewiacyjnych zachowań u dzieci upatruje się w niewłaściwej matczynej opiece bądź jej braku. Szczególnie niekorzystna jest „deprywacja macierzyńska”, czyli nieobecność matki we wczesnym dzieciństwie (Bowlby 1953, za: Giddens 2004: 134). W pierwszych latach życia dziecka opieka nad nim nie powinna być powierzana innym osobom, bo matki z jej naturalną umiejętnością odczytywania dziecięcych potrzeb i wiedzą, co jest dla dziecka najlepsze, nie da się tak po prostu zastąpić. Przekonane są o tym same kobiety, które nie mogąc zajmować się dziećmi przez 24 godziny na dobę w związku z aktywnością zawodową, mają poczucie winy.

Tradycyjny sposób postrzegania macierzyństwa obejmuje także idealizację roli matki (Budrowska 2001: 107, 112). Zakłada się, że posiadanie dziecka przez kobietę i opieka nad nim wywołują jedynie pozytywne emocje. Skoro kobiety są predestynowane do bycia matką, chcą mieć dzieci i wiedzą jak się nimi zajmować, nie ma tu mowy o takich zjawiskach jak depresja poporodowa, baby blues, nieradzenie sobie z dzieckiem czy odczuwanie wobec niego innych uczuć niż miłość. „W społecznym przeświadczeniu funkcjonuje mocno zakorzeniony ideał dobrej, czułej, delikatnej, bezwarunkowo i niezmiennie kochającej, akceptującej, wyrozumiałej matki” (tamże: 112). Mimo „kosztów” macierzyństwa w postaci 
rezygnacji z własnych potrzeb, poświęcenia i podporządkowania własnego życia dziecku, kobieta odczuwa wyłącznie radość i szczęście z powodu bycia matką.

Zdaniem B. Budrowskiej, macierzyństwo można określić jako instytucję totalną, ze względu na przymus bycia matką i wpisanych w tę rolę obowiązków, swoiste zniewolenie i brak autonomii kobiet, których życie jest podporządkowane opiece nad dzieckiem (Budrowska 1997: 304). Rolę nadzorców, nieodzownych w instytucjach totalnych, pełnią, jej zdaniem, ,zinternalizowane normy wykształcone w toku socjalizacji - wiedza na temat obowiązków macierzyńskich i chęć im sprostania: intencje i kompetencje" (tamże: 305). Poza tymi wewnętrznymi, psychospołecznymi mechanizmami kontroli społecznej (Szczepański 1970: 217, 218), funkcjonuje także zewnętrzna kontrola ze strony innych członków społeczeństwa, stojących na straży „prawidłowego” wypełniania roli kobiety-matki i piętnujących wszelkie odstępstwa od normy. Za porównaniem macierzyństwa do instytucji totalnej przemawia także fakt, że z byciem matką wiąże się rutynowy, ściśle zaplanowany i narzucony rozkład dnia, czy brak zapłaty za wykonywaną pracę (Budrowska 1997: 305). Dałoby się tu także zaobserwować, występujące w instytucjach totalnych, zjawisko przekształcania osobowości „stotalizowanych matek" oraz stosowane przez nie różne techniki adaptacyjne (tamże).

Elisabeth Badinter w pracy Historia miłości macierzyńskiej przekonuje, że przedstawiony wyżej sposób postrzegania roli matki nie funkcjonuje „od zawsze”. Autorka pokazuje „ewolucję postaw macierzyńskich” i jej przyczyny (Badinter 1998: 21). Zwraca uwagę, że w kulturze europejskiej ideologia macierzyństwa opartego na miłości, czułości, bliskiej i silnej relacji z dzieckiem pojawia się dopiero pod koniec XVIII w. Wcześniej, ze względu na niski status dzieci w rodzinie i traktowanie ich jako ciężaru, a także jako złe i zepsute istoty, postawy obojga rodziców wobec potomstwa cechowały się obojętnością, a nawet niechęcią, emocjonalnym chłodem i surowością (tamże: 40-43). Piętnowano „czułe i zniewieściałe” zachowanie matek, które w ten sposób psuły dzieci i ,pogłębiały ich naturalną skłonność do występku" (tamże: 42). Badacze zauważają, że macierzyństwa nie kojarzono z czułością i emocjonalnością, gdyż w ówczesnych rodzinach ani relacje między małżonkami, ani między rodzicami i dziećmi nie były oparte na uczuciach i raczej niewiele miały wspólnego z czymś, co określa się mianem rodzinnego ciepła (Szlendak 2010: 315). Powstaniu więzi między kobietą a jej nowo narodzonymi dziećmi nie sprzyjał zwyczaj oddawania ich mamkom, rozpowszechniony w wyższych klasach społecznych, co wiązało się często z rozłąką z dzieckiem na dłuższy czas. Jak stwierdza E. Badinter, ,pierwszym krokiem na drodze do odrzucenia dziecka była odmowa karmienia go piersią", którą przedstawicielki arystokracji usprawiedliwiały szkodliwością tej czynności dla własnego zdrowia i urody, niestosownością, czy po prostu ograniczeniami w prowadzeniu dotychczasowego życia towarzyskiego (Badinter 1998: 68). Po mamce opiekę nad dzieckiem przejmowała niania, następnie odsyłano je ,na naukę” do innej rodziny, czy oddawano do szkół, a zatem kontakt z nim był ograniczony (tamże: 91, 
94). Brak zainteresowania potomstwem znajdował wyraz w obojętności wobec śmierci córki czy syna, której to postawy, zdaniem autorki, nie można wyjaśniać jedynie wysoką śmiertelnością dzieci i koniecznością „,uodpornienia się” rodziców na taką sytuację (tamże: 61-65). Badaczka zwraca uwagę na zjawisko „selektywnej miłości” - „kochano” potomka wtedy, gdy miał on znaczenie i wartość dla rodziny (np. jako syn czy jako najstarsze dziecko). Dopiero gdy zdano sobie sprawę ze skali problemu umieralności dzieci i jego społecznych konsekwencji, „odkryto" na nowo instynkt macierzyński, rozumiany jako spontaniczna, bezwarunkowa miłość do dziecka cechująca każdą matkę (tamże: 105). W definiowaniu macierzyństwa zaczęto przyjmować perspektywę dziecka i jego potrzeb. Zwracano uwagę na znaczenie osobistej opieki rodzicielki, w tym karmienia piersią, dla rozwoju dzieci, a przede wszystkim ich przeżycia. By skłonić kobiety do zajmowania się własnymi córkami i synami oraz okazywania im uczuć, podkreślano doniosłość roli matki dla całego społeczeństwa. Przekonywano, że nikt inny nie może ich zastąpić w wypełnianiu ,potrzebnych i «szlachetnych»” zadań macierzyńskich (tamże: 106). Powstał model „dobrej matki”, czułej i troskliwej, zapewniającej dziecku jak najlepszą opiekę i poświęcającej dla niego inne sfery życia, ale przy tym szczęśliwej, zadowolonej i spełnionej w swej roli. „Matka XIX i pierwszej połowy XX w. jest skłonna rezygnować ze swojej wolności oraz redukować swój egoizm, poświęcając coraz więcej czasu dziecku a mniej sobie" (Sikorska 2009a: 170). Nawet jeśli nie wszystkie kobiety realizują przeznaczony im scenariusz „bezgranicznie poświęcającej się matki”, to muszą borykać się z poczuciem winy (Badinter 1998: 167). „Uwięziona w roli matki, kobieta nie będzie mogła już z niej wyjść pod groźbą moralnego potępienia" (tamże: 173). W związku z rozwojem psychoanalizy matkom zaczęto przypisywać pełną odpowiedzialność za rozwój dziecka i jego szczęście i obwiniać za jego choroby, niepowodzenia i problemy (tamże: 173; Budrowska 2000: 39; Sikorska 2009a: 171).

Jak zauważają autorzy analizujący przemiany modeli i wzorów macierzyństwa, społeczne oczekiwanie zaangażowania kobiet w opiekę nad potomstwem i poświęcenie się przez nie roli matki prowadziło do poprawy ich społecznego statusu. „Stały się one bowiem główną «podporą» domu i rodziny, ich zdanie w sprawie wychowania dzieci zaczęło się liczyć. Dodatkowo «dobra matka» zyskała wsparcie ze strony religii, która przyrównywała ją do świętej, spełniającej «posłannictwo», będącej «powołaną» do opieki nad dziećmi” (Sikorska 2009a: 171). Zdaniem Tomasza Szlendaka, to podniesienie prestiżu nie tylko roli matki, ale także roli żony i gospodyni domowej wiązało się ze wzrostem prestiżu domowej przestrzeni, która zaczęła być doceniana przez mężczyzn jako miejsce odpoczynku i wytchnienia od aktywności w sferze publicznej (Szlendak 2010: 335). W polskim społeczeństwie zaczęto propagować ideał Matki Polki, cechującej się całkowitym poświęceniem rodzinie, a także patriotyzmem wyrażającym się w rodzeniu i wychowywaniu nowych członków narodu (Titkow 2012; Budrowska 2000: 192-193; Monczka-Ciechomska 1992: 95). Znaczenie i trwałość 
figury Matki Polki, wciąż funkcjonującej w społecznej świadomości oraz publicznym dyskursie, jest wynikiem dziedzictwa historycznego i szczególnej roli kobiet w okresie zaborów - matek patriotek, przekazujących młodemu pokoleniu narodowe wartości, „strażniczek tradycji narodowej” (Monczka-Ciechomska 1992: 95; Titkow 1995: 13-14; Bator 1999: 35, 37). Źródłem polskiego „etosu macierzyństwa” jest także kult maryjny - „świeckim odpowiednikiem” Matki Boskiej mają być kobiety wyrzekające się własnych potrzeb, bezgranicznie oddane rodzinie i służące tym samym całemu społeczeństwu (Monczka-Ciechomska 1992: 95; Chołuj 1992: 31, 33, za: Budrowska 2000: 192, 195). Chociaż, jak zauważa B. Budrowska, współcześnie traci na znaczeniu patriotyczny wymiar wzorca Matki Polki, wciąż obowiązuje nakaz macierzyństwa i model „dobrej matki” (Budrowska 2000: 195).

Gdy w tradycyjnym modelu macierzyństwo jest traktowane jako centralny, niemal konstytutywny element kobiecości, w odniesieniu do mężczyzn rola rodzicielska jest uznawana za peryferyjną w repertuarze ,właściwych” im, oczekiwanych społecznie ról. Męskość i ojcostwo utożsamiane są z pełnieniem roli głowy rodziny, odpowiedzialnością za bezpieczeństwo materialne jej członków, a zatem $\mathrm{z}$ rolami zewnętrznymi, pozadomowymi, realizowanymi $\mathrm{w}$ sferze publicznej. Scenariusz roli ojca w tradycyjnym modelu nie jest, jak stwierdza Tomasz Szlendak, „przesadnie skomplikowany” - ojciec ma iść do pracy i zarobić pieniądze na utrzymanie rodziny (Szlendak 2009: 64). Według Talcotta Parsonsa, ,[...] następstwem tej roli [głównego żywiciela rodziny - przyp. K.D.-G.] jest znacznie skromniejszy udział męża niż żony w wewnętrznych sprawach domowych. W związku z tym «prowadzenie domu» i troska o dzieci jest wciąż podstawową treścią funkcjonalną roli dorosłej kobiety w ramach utylitarnego podziału pracy" (Parsons 1972: 252-253). Zdaniem autora, sytuacji tej nie zmienia fakt podjęcia przez kobietę pracy zawodowej, bowiem jej zarobki i pozycja na rynku pracy są niższe od zarobków i pozycji mężczyzny (tamże: 254). Ze względu na pochłonięcie pracą zawodową rola ojca wiąże się z częstą nieobecnością w domu i ograniczonym kontakcie z dziećmi, byciem rodzicem ,na dystans” (distant breadwinner - Pleck 1987: 86). Ojcostwo angażuje mężczyznę tylko częściowo, podczas gdy macierzyństwo (także to łączone z aktywnością pozadomową) „obowiązuje” kobietę 24 godziny na dobę.

Jak stwierdza Kazimierz Pospiszyl, „ojcostwo jest z pewnością mniej znaczącym faktem w życiu mężczyzny niż macierzyństwo w życiu kobiety" (Pospiszyl 2004: 24). Wiąże się to, po pierwsze, ze wspomnianym różnym „obciążeniem" rolą rodzicielską kobiet i mężczyzn, jeżeli chodzi o obowiązki związane z opieką nad dzieckiem i poświęcanym im czasem. Po drugie, panuje przekonanie, że kobieta bardziej niż mężczyzna „potrzebuje dziecka”, by czuć się spełniona, by „,czuć się osobą pełnowartościową” (Giza-Poleszczuk 2002a: 249; Poleszczuk 2002: 274). Dla mężczyzny istotne jest przede wszystkim być aktywnym zawodowo oraz mieć żonę i dzieci. „Mężczyźni niezmiennie definiu- 
ją swoją męskość poprzez pracę (work based gender), ale także przez «posiadanie rodziny». Kobiety definiują swoją kobiecość przez macierzyństwo i «bycie» rodziną, nie podkreślając aktu jej «posiadania» - jak to nieświadomie robią mężczyźni - a raczej akt aktywnego uczestnictwa w jej codziennym funkcjonowaniu" (Holter 2005, za: Kwiatkowska, Nowakowska 2006: 19). To na zawodowej roli mężczyzny opiera się jego pozycja i autorytet w rodzinie, a także poczucie własnej wartości. Potwierdzają to badania przeprowadzone w rodzinach z bezrobotnymi mężczyznami, których ,niewywiązywanie się” z roli żywiciela powodowało obniżenie samooceny oraz różnego rodzaju napięcia i zakłócenia w relacjach z partnerką i dziećmi (Grochalska 2006; Kryczka 1997). Mamy tu zatem do czynienia z odmiennym odczuwaniem przez przedstawicieli obu płci bycia rodzicem, przypisywaniem temu innego znaczenia, także w konstruowaniu własnej tożsamości.

Uproszczeniem byłoby stwierdzenie, że tradycyjnie ujmowana rola ojca ogranicza się do utrzymywania rodziny i bycia jej głową. W związku z jego aktywnością w sferze publicznej oraz przypisywanymi mu cechami i kompetencjami mężczyzna jest łącznikiem rodziny ze światem zewnętrznym, uosobieniem pozarodzinnych wartości i ról, autorytetem i wychowawcą, duchowym przewodnikiem (Parsons 1969: 75, 79; Pleck 1987: 84; Lamb 1987, za: Williams 2008 : 488). Dowodzi tego m.in. Erich Fromm, pokazując odmienność ról matki i ojca i inne ich relacje z dzieckiem: „Matka jest ciepłem, matka jest pokarmem, matka jest pełnym błogości stanem zadowolenia i bezpieczeństwa. [...] Matka jest domem, z którego wychodzimy, jest naturą, glebą, oceanem; ojciec nie reprezentuje żadnego takiego naturalnego domu. W pierwszych latach życia jego kontakty z dzieckiem są bardzo ograniczone, jego znaczenie dla dziecka w tym pierwszym okresie nie da się porównać ze znaczeniem, jakie odgrywa matka. Ale podczas gdy ojciec nie reprezentuje naturalnego świata, reprezentuje on drugi biegun ludzkiego istnienia: świat myśli, przedmiotów, które są dziełem rąk ludzkich, świat prawa i ładu, dyscypliny, podróży i przygody. Ojciec jest tym, który uczy dziecko, tym, który mu wskazuje drogę w świat" (Fromm 1971: 51, 55). Wyraźnie widać tu odwołanie do opisywanej przez S. Ortner opozycji natura - kultura nakładanej na kategorie kobiecości i męskości. W ujęciu tym podkreśla się wychowawczą rolę ojca. Chociaż to matkę postrzega się jako odpowiedzialną za socjalizację dziecka w pierwszym okresie jego życia, to jednak jej zadania ogranicza się do opieki, dbanie o prawidłowy rozwój fizyczny i psychiczny oraz wyposażenie dziecka w elementarną wiedzę na temat zasad zachowania. Kobieta „miała pilnować, aby dzieci nie przeszkadzały zmęczonym po pracy mężom - były ciche, zadbane, ułożone” (Kwak 2007: 73). Ojciec „przejmuje” wychowanie dzieci, gdy stają się one bardziej samodzielne (Krajewska 2008: 72). Jak opisują to autorzy Historii ojców i ojcostwa, ,panował zwyczaj, że roztaczanie opieki nad maleństwem do siódmego roku życia należało do matki, a przed ojcem nie stawało, zanim nie osiągnęło wieku, w którym zasługuje się na poważanie" (Delumeau, Roche 1995: 64). Męż- 
czyzna wkracza w życie dziecka, gdy trzeba przygotować je do wejścia w „świat pozarodzinny - świat nauki, pracy, norm społecznych" (Jaworowska 1985: 546, za: Krajewska 2008: 68).

Erich Fromm podkreśla różnicę między bezwarunkową miłością macierzyńską, której nie trzeba zdobywać i na którą nie trzeba zasługiwać, a miłością ojcowską, obwarowaną warunkami i oczekiwaniami, które trzeba spełnić, by być kochanym przez ojca (Fromm 1971: 52, 56). Zdaniem K. Pospiszyla, „ojciec będąc pozbawiony tak silnego jak matka związku biologicznego z dzieckiem nie posiada «danej z natury» umiejętności kochania dziecka tylko dlatego, że jest to jego dziecko" (Pospiszyl 2007: 30). A zatem to ojciec jest tym rodzicem, wobec którego dziecko ma być posłuszne, który stawia przed nim określone wymagania i zasady postępowania - czyli wychowuje je i przygotowuje do wejścia w pozarodzinne życie społeczne, nagradzając je własną miłością bądź karząc jej odebraniem. Maria Janukowicz na podstawie wyników badań przeprowadzonych wśród ojców oraz ich dzieci stwierdza: ,[...] ojcowie najczęściej nauczają i pouczają. [...] Ojcom najbliższa jest bowiem rola edukatorów. [...] Ojcowie raczej skąpo obdarzają dzieci, zwłaszcza synów, bezpośrednimi manifestacjami emocjonalnej akceptacji i miłości. Najbardziej zauważani są, gdy karcą" (Janukowicz 2002: 46).

Jean Delumeau i Daniel Roche pokazują, jak kształtował się tradycyjny model roli ojca (Delumeau, Roche 1995). Zwracają uwagę, że źródeł władzy i autorytetu mężczyzny w rodzinie doszukiwać się można w prawie rzymskim, które „z jednej strony posłużyło do konceptualizacji samego pojęcia ojcostwa, z drugiej zaś stanowiło zbiór sentencji i rozwiązań technicznych w tej dziedzinie" (tamże: 28). Ojciec był tym, który „daje albo życie, albo śmierć”, co odnosiło się nie tyle do udziału mężczyzny w akcie prokreacji, ale do uznania dziecka i przyznania mu tym samym prawa do życia. Ojcostwo było definiowane jako wynik woli mężczyzny, który „ustanawiając się ojcem”, zobowiązywał się do utrzymania potomstwa (tamże: 28-29). W prawie kanonicznym z kolei wprowadzono zasadę, że ojcem dziecka jest mąż matki - ,[...] ojcem jest ten, na kogo wskazuje prawowite małżeństwo. [...] Mężczyzna może w ciągu swego życia być naprawdę uznany za ojca jedynie w małżeństwie" (tamże: 32-34). Mimo społecznego wykluczania nieślubnych dzieci, mężczyźni mają wobec nich zobowiązania alimentacyjne, zgodnie z zasadą „Ten kto płodzi dziecko, powinien je żywić” (tamże: 41).

Powyższe rozważania pokazują, że po pierwsze, ojcostwo, w przeciwieństwie do niepodważalnego, niewymagającego dowodów macierzyństwa, było czymś uznaniowym, arbitralnym, co dopiero musi zostać nazwane albo przez samego mężczyznę albo przepisy prawa. Po drugie, z ojcostwem nieodłącznie wiąże się obowiązek materialnego zabezpieczenia dziecka i jego matki, a także odpowiedzialność za jego edukację. Od samego początku w rolę ojca wpisana była władza - ,[...] dziecko jest i pozostaje istotą, którą stwarza pater, owocem jego woli i władzy, a więc i przedmiotem jego władzy. Jako stworzenie swego ojca, nie może ono istnieć najpierw fizycznie, następnie prawnie bez jego pomocy [...]" 
(Delumeau, Roche 1995: 44). W patriarchalnym społeczeństwie to mężczyzna przekazuje synowi imię i majątek i zależy to tylko od jego woli (,Pater może zawsze syna wydziedziczyć"). On także decyduje o przyszłości dzieci, w tym o ich małżeństwie (tamże: 46, 49, 53). Wyrazem ojcowskiej władzy jest również prawo do karania dziecka, przyzwalające na stosowanie przemocy fizycznej. Charakter jego relacji z dziećmi oddają następujące stwierdzenia z czasów średniowiecza przytaczane przez autorów Historii ojców i ojcostwa: ,im bardziej ojciec kocha dziecko, tym pilniej je naucza i tym częściej je bije”, ,[...] kto miłuje swego syna, często używa na niego rózgi" (tamże: 57). Autorytet ojca wzmacniany był przez analogię do Boga Ojca oraz do władcy - „ojca narodu” (Badinter 1998: 31; Duch-Krzystoszek 2007: 16-17). Pojęcie „władzy ojcowskiej” zostało zastąpione pojęciem „,władzy rodzicielskiej” dopiero w XX w. (Delumeau, Roche 1995: 376). Ojciec stopniowo tracił pozycję „króla i sędziego” w rodzinie (Pospiszyl 1980: 57, za: Grochalska 2006: 115), jednak w tradycyjnym modelu płci kulturowej ojcostwo nadal jest kojarzone $\mathrm{z}$ byciem głową rodziny, wychowawcą i autorytetem.

Jak zauważa E. Badinter, ,„[...] rola ojca, matki i dziecka są określane przez potrzeby i wartości dominujące $\mathrm{w}$ danym społeczeństwie. Kiedy latarnia panującej ideologii oświetla tylko mężczyznę-ojca, obdarzając go wszelką władzą, matka schodzi w cień i jej status upodabnia się do statusu dziecka. I odwrotnie, kiedy społeczeństwo interesuje się dzieckiem, jego przetrwaniem i wychowaniem, światło jest skierowane na matkę, która staje się postacią główną, na niekorzyść ojca” (Badinter 1998: 21). W społeczeństwie „dzieciocentrycznym”, gdy wzrasta pozycja dziecka w rodzinie, kobieta jako jego rodzicielka i opiekunka wysuwa się na pierwszy plan. Oczekuje się od niej, by była przede wszystkim i tylko matką i zamyka w totalnej instytucji macierzyństwa. Mimo podkreślania znaczenia jej roli dla całego społeczeństwa, pozycja społeczna kobiety w patriarchalnym społeczeństwie jest niska. Nawet w „domowym królestwie” jej panowanie jest tylko pozorne, bo pozostaje ona zależna finansowo od mężczyzny oraz musi uwzględniać i potwierdzać w oczach dzieci jego autorytet, na przykład traktując jako wyrocznię i sędziego w kwestiach wychowawczych. Ojcu pozwala się być rodzicem „na dystans”, nie umniejszając przy tym jego społecznego statusu, bo umożliwiając mu pełną aktywność $\mathrm{w}$ innych sferach życia, wiążącą się $\mathrm{z}$ dostępem do społecznie cenionych dóbr. Przedstawiony powyżej tradycyjny model macierzyństwa i ojcostwa, różnicujący cechy i zadania wpisane w rolę matki i ojca, podtrzymuje zatem i utrwala patriarchalny porządek społeczny (Rich 1976, za: Budrowska 2000: 52). 


\section{Rozdział 3. Nowoczesny model kobiecości i męskości}

\section{1. „Depolaryzacja rodzajów” i zmiana relacji płci}

We współczesnym społeczeństwie tradycyjny model płci ściera się z nowym sposobem postrzegania kobiet i mężczyzn, właściwych im cech, ról i sfer aktywności (Arcimowicz 2003). Konkurencyjne wobec tradycyjnych ujęć nowe definicje kobiecości i męskości opierają się na równości i partnerstwie kobiet i mężczyzn (tamże: 55). Dochodzi tu do odrzucenia dualizmu płci oraz przyznania równego znaczenia i równej wartości temu co męskie i kobiece. „Koncepcja specjalizacji, a więc podziału ról społecznych ze względu na płeć, jest zastąpiona koncepcją komplementarności i androgyniczności. Mężczyzna może realizować się w rolach uważanych za kobiece, kobieta zaś może podejmować role męskie" (tamże). Zmienia się także sposób wyjaśniania kobiecości i męskości i różnic między nimi. Podczas gdy tradycyjny punkt widzenia odwoływał się do natury i zakładał, że cechy oraz role kobiece i męskie są przeciwstawne, z góry dane i raz na zawsze ustalone, tak nowe spojrzenie na płeć wiąże się z tezą o kulturowym pochodzeniu wzorów kobiecości i męskości oraz rozróżnieniem płci biologicznej i kulturowej (tamże: 56). W nowoczesnym modelu płci granice kobiecości i męskości są płynne, zmienne, w ich ramach pojawia się wiele różnych koncepcji, odmian kobiecości i męskości, spośród których jednostka może wybierać, dążąc do samorealizacji i osiągnięcia pełni swego człowieczeństwa (tamże).

Krytyka tradycyjnego „reżimu płci” rozwijała się przede wszystkim w ramach ruchu feministycznego i gender studies. Jak ujęła to Kathleen Barry: „Na początku była płeć. Płeć męska i płeć żeńska [...]. Płeć była biologią i przeznaczeniem. Taka była wersja patriarchalna. Aż pojawiły się feministki" (Barry 1996: 188, za: Hyży 2003: 56). Najogólniej rzecz biorąc, feminizm oznacza postawę obejmującą świadomość istnienia społecznych nierówności płci i uznawanie ich za niesprawiedliwe, przekonanie o ich kulturowej podstawie oraz dążenie do zmiany społecznej i osiągnięcia równości płci (Titkow 1998: 213). Jak stwierdza Ewa Malinowska, „równolegle z rozwojem europejskiej myśli feministycznej, wraz ze sporami na temat kondycji kobiet, interpretacji idei równości i wolności w odniesieniu do kobiet itd., w rzeczywistości społecznej dokonywała się powolna i stopniowa zmiana dziedzin i pól kobiecej aktywności” (Malinowska 2000: 17). Ruch feministyczny i zmiana społecznego położenia kobiet warunkowały się wzajemnie (Reszke 1976, za: Malinowska 2000: 17). Feminizm cechuje wielość koncepcji, programów i strategii działań (Humm 1993; Ślęczka 1999; Malinowska 2000: 18; Putnam 
Tong 2002). Można jednak, za E. Malinowską, wskazać uniwersalne cele kolejnych fal ruchu feministycznego (Malinowska 2000; 2009). Pierwsza fala ruchu, nieokreślanego jeszcze jako feministyczny lecz ruch kobiet, wiązała się z walką o równość prawa bez względu na płeć, a przede wszystkim o przyznanie kobietom praw wyborczych (stąd też powszechna nazwa: ruch sufrażystek) (Malinowska 2009: 47). Feministki drugiej fali dążyły do zmiany społecznego statusu kobiet nie tylko poprzez zmiany legislacyjne (które okazały się niewystarczające), ale przede wszystkim obyczajowe (tamże: 49, 50). Piętnując patriarchalny porządek społeczny i zniewolenie kobiet odwoływano się do koncepcji teoretycznych, prowadzono naukowe badania w ramach women's studies, a następnie gender studies. Przedstawiciele działającego obecnie ruchu feministycznego na rzecz demokracji parytetowej (trzecia fala) traktują społeczne nierówności płci, mające swe źródło w tradycyjnym modelu kobiecości i męskości, jako problem całego społeczeństwa, a nie tylko „kobiecą kwestię” (Malinowska 2003: 93; 2009). Pokazując znaczenie egalitaryzmu jako uniwersalnej i demokratycznej wartości, domagają się zmiany kulturowego modelu społeczeństwa (Malinowska 2003: 99; 2009: 54, 55).

Negatywne skutki funkcjonowania jednostek w sztywnym gorsecie tradycyjnych definicji płci dostrzegali także mężczyźni, chociaż patriarchalna kultura przynosiła im więcej przywilejów i korzyści. Studia nad mężczyznami (men’s studies) nagłośniły kwestię szkodliwości tradycyjnego modelu męskości nie tylko dla kobiet, ale i dla samych mężczyzn oraz całego społeczeństwa (Arcimowicz 2003: 59; Brod 1987). Jak określił to Robert Brannon: „Stopniowo zdawałem sobie sprawę, że gotowy szablon męskiej roli ogranicza i pozbawia prawdziwego potencjału zarówno mnie samego, jak i każdego mężczyznę, którego znam" (Brannon R. 1976, za: Brannon 2002: 31). Trudność sprostania społecznym oczekiwaniom oraz potrzeba udowodnienia i sobie, i innym swojej męskości jest dla wielu mężczyzn źródłem napięć, wewnętrznego konfliktu, niskiej samooceny, a także problemów zdrowotnych (np. stres z powodu relatywnie niskich osiągnięć zawodowych, choroby sercowo-naczyniowe) (Pleck 1981, za: Kwiatkowska, Nowakowska 2006: 30, 31; Brannon 2002: 215; Zyra 2006: 143; Badinter 1993: 122). Badacze wskazują na zjawisko „społecznego niedostosowania” części mężczyzn i związane z nim społeczne problemy (trwałe bezrobocie, przestępczość, przemoc, uzależnienia, wczesna śmiertelność) (Dench 1998: 196).

Wreszcie, obok ruchu feministycznego, studiów nad kobietami i mężczyznami czy szerzej: gender studies, do rozpadu tradycyjnej płci kulturowej przyczyniły się, zdaniem Kennetha J. Gergena, także badania i rozważania nad zjawiskami transseksualizmu i homoseksualizmu (Gergen 2009: 178). Podały one bowiem w wątpliwość dwa kluczowe kryteria przy określaniu płci jednostki: różnice anatomiczne oraz preferencje seksualne (tamże).

Problem kulturowych definicji kobiecości i męskości oraz relacji między płciami był także przedmiotem refleksji socjologów spoza wyżej wymienionych nurtów. Zdaniem Ewy Malinowskiej, krytyka patriarchatu wiązała się ze zmia- 
ną sposobu ujmowania relacji między jednostką a społeczeństwem w socjologii, która przez długi czas odgrywała dużą rolę w podtrzymywaniu patriarchalnego porządku społecznego (np. poprzez wykazywanie jego funkcjonalności czy też ignorowanie problemu nierówności płci i jego kulturowych źródeł) (Malinowska 2003: 92; Turner J.H. 2004: 264). Autorka podkreśla, że rozwój feminizmu i wzrastająca emancypacja kobiet oraz pojawienie się krytycznego podejścia do patriarchatu w socjologii przebiegały równolegle, wpływając na siebie nawzajem (Malinowska 2003: 92). Socjologowie zaczęli traktować patriarchalne społeczeństwo jako jeden z możliwych, nie jedyny, model relacji między płciami i dostrzegać, że taki porządek społeczny ogranicza wolność, autonomię, podmiotowość jednostek, zarówno kobiet, jak i mężczyzn (tamże: 93). Do odrzucenia tradycyjnego sposobu ujmowania jednostki jako osoby o określonej płci biologicznej i kulturowej przyczyniło się również pojawienie się w socjologii postmodernistycznych koncepcji, negujących konwencje i ,raz na zawsze ustalone” prawdy, głoszących pluralizm i relatywizm, ,zacierających granice między pojęciami, także między męskością i kobiecością" (Winiarska 2008: 27).

Jak zauważa E. Malinowska, na potrzebę i nieodwracalność zmiany patriarchalnego porządku wskazywali tacy społeczni badacze, jak Ulrich Beck, Geert Hofstede czy Alain Touraine (Malinowska 2003; 2009). Konieczność oparcia organizacji społeczeństwa przyszłości na równym statusie kobiet i mężczyzn była przez nich uzasadniana przemianami demograficznymi, gospodarczymi, społecznymi i politycznymi (Hofstede, Beck) oraz leżącym w interesie całego społeczeństwa uwolnieniem podmiotowości i kreatywności jednostek, uprzedmiotowionych przez patriarchalne konstrukty kobiecości i męskości (Touraine) (Malinowska 2003: 103; 2009: 56). Zdaniem Ronalda Ingleharta oraz Pippy Norris, osiągnięcie egalitaryzmu płci jest nieuniknione w rezultacie społecznej modernizacji zachodzącej na całym świecie: „Zmiana społeczna wydaje się w ogromnej części deterministyczna, a więc wzbierająca fala równouprawnienia płci pozostawiona sama sobie wyeliminuje w końcu wszystkie tradycyjne bariery stojące na drodze kobiet do pełnego uczestnictwa w życiu publicznym” (Inglehart, Norris 2009: 188). Autorzy, analizując systemy wartości oraz poglądy na role kobiet i mężczyzn w międzykulturowych badaniach, stwierdzają „,wzbierającą falę równości”, tj. wzrastający poziom równouprawnienia płci na całym świecie, który to jednak proces przebiega w różnym tempie i na różną skalę w zależności od typu społeczeństwa (Inglehart, Norris 2009). Wskazują na szereg czynników: ekonomicznych, politycznych, kulturowych, mających wpływ na poparcie równouprawnienia płci. Przedstawiając w skrócie wyniki ich analiz można by powiedzieć, że najbardziej egalitarne są społeczeństwa najlepiej rozwinięte, postindustrialne, bogate, demokratyczne, zsekularyzowane, w których wyżej ceni się wartości postmaterialistyczne (tamże: 185). Autorzy wskazują wpływ poziomu rozwoju gospodarczego i dobrobytu (zależny z kolei od typu gospodarki) i powiązanego z nim poziomu rozwoju społecznego na 
zmianę wartości i światopoglądu. W społeczeństwach biedniejszych priorytetem jest zaspokojenie podstawowych potrzeb życiowych, a niepewność dnia codziennego wzmacnia przywiązanie do tradycji, w tym patriarchalnego podziału ról oraz niechęć zmiany. Dobrobyt, wysoki poziom życia i bezpieczeństwa egzystencjalnego sprzyja natomiast kulturowej zmianie, kwestionowaniu tradycji jako ograniczenia oraz liberalizacji obyczajowej: „ludzie zaczynają przywiązywać coraz większą wagę do kwestii jakości życia, autonomii jednostki, swobodnej ekspresji" (tamże 2009: 27). Autorzy nazywają to „przejściem od wartości tradycyjnych do świecko-racjonalnych (powiązanych ze zmniejszeniem się roli tradycyjnej rodziny) oraz od wartości przetrwania do wartości swobodnej ekspresji (związanych ze wzrostem równouprawnienia płci)" (tamże: 177).

Jak zostało to już zauważone, powstanie nowoczesnego modelu płci wymagało zaistnienia określonych warunków społecznych. Autorzy podejmujący analizę współczesnego społeczeństwa (niektórzy z nich używają określenia „ponowoczesne", inni - jak A. Giddens -"późnonowoczesne") wskazują na procesy indywidualizacji i wzrost podmiotowości społecznych aktorów oraz omawiane w pierwszym rozdziale zjawisko refleksyjności tak jednostki, jak całego społeczeństwa (m.in. Giddens 2001b; Beck 2002, Kwak 2005; Slany 2008). Zdaniem Ulricha Becka, jednym z wymiarów indywidualizacji jest „odczarowanie”, czyli odrzucenie tradycyjnych przekonań dotyczących działania, wiary i norm (Beck, Beck-Gernsheim 2002: 2, za: Kwak 2005: 22). Prowadzi to m.in. do ,rozpadu istniejących wcześniej form społecznych, co ujawnia się przez coraz większą kruchość takich kategorii jak status społeczny, role płci, rodzina [...]" (tamże). Jednostka nie jest już ograniczona przez społeczeństwo i nakładane na nią zobowiązania związane z przynależnością klasową czy byciem kobietą/mężczyzną, nie tylko może, ale musi dokonywać wyborów, samookreślić się. Jej biografia nie jest już wyznaczana przez społeczeństwo, ale jest tworzona przez nią samą (Beck 2002: 202). Wymaga to wykształcenia u społecznych aktorów ,indywidualistycznej mentalności” (Duch-Krzystoszek 1998, za: Kwak 2005: 54), poczucia podmiotowości i sprawstwa, otwartości i elastyczności. „Jednostki muszą nauczyć się myśleć o sobie jako o twórcach własnego życia, umieć odpowiadać na konieczność wprowadzania zmian, dopasowywania się do zmieniających się warunków" (Kwak 2005: 23).

Podmiotowość jednostki wyraża się m.in. w uwolnieniu się od kolektywnych tożsamości płci „obowiązujących” w tradycyjnym modelu płci kulturowej (Malinowska 2009: 53). Jak określa to Irena Machaj, ,jednostka buduje obraz siebie nie z cech, które «powinna» lub «trzeba» posiadać jako kobieta/mężczyzna, lecz $\mathrm{z}$ cech, które uznaje za ważne i znacząco oddające jej walory społeczne niezależ-

${ }^{1}$ Wskaźnikami rozwoju społecznego (Human Development Index) są poziom wiedzy (umiejętność czytania i pisania oraz wykształcenie), zdrowie (oczekiwana długość życia w momencie narodzin) oraz standard życia (PKB na głowę) (Inglehart, Norris 2009: 31). 
nie od tego, czy mieszczą się one w tradycyjnym wzorze kobiety czy mężczyzny” (Machaj 2009: 21). Odwołując się do słów Simone de Beauvoir: „człowiek nie jest istotą, która jest dana, lecz istotą, która czyni z siebie taką, jaką jest" (Beauvoir 1972: 77, za: Uliński 2001: 286). Sposoby realizowania płci stają się przedmiotem wyboru i nowoczesne społeczeństwo przenika „Connellowski duch wielu form męskości” oraz kobiecości (Gębala 2007: 9; Bradley 2008: 64). Jak opisuje to Renata Siemieńska, „następuje pluralizacja ról i wyobrażeń, stylów życia w subpopulacji kobiet i mężczyzn, zarysowują się różnokierunkowe zmiany będące odzwierciedleniem coraz bardziej różnicujących się warunków życia, potencjalnych i realizowanych scenariuszy" (Siemieńska 2007b: 307-308).

Przypomnijmy, że zdaniem A. Giddensa kwestionowane i podważane w warunkach refleksyjności jednostki i społeczeństwa tradycje, by przetrwać, muszą „poddać się dyskursywnemu uzasadnieniu” i wejść w dialog z innymi tradycjami i alternatywnymi sposobami postępowania (Giddens 2009: 141). Analizując przypadek ,płci kulturowej jako tradycji”, autor stwierdził: „Dziś w wyniku głębokich zmian strukturalnych, połączonych z trwającymi od wielu dziesięcioleci wysiłkami ruchów feministycznych, podziały między mężczyznami i kobietami, w tym także najbardziej intymne powiązania między płcią kulturową, seksualnością i tożsamością, zostały publicznie podane w wątpliwość. Uczynienie ich przedmiotem dyskusji oznacza domaganie się ich dyskursywnego uzasadnienia. Nikt nie może już dziś powiedzieć: «Jestem mężczyzną i tacy właśnie są mężczyźni», «Odmawiam dalszej dyskusji o tych sprawach» - oświadczenia, które częściej znajdują wyraz w czynach niż słowach. Zachowanie i postawy trzeba uzasadniać, kiedy zostanie się do tego wezwanym" (tamże: 142). A. Giddens wskazuje na przenikanie wiedzy socjologicznej do wiedzy potocznej, „zsocjologizowanie” tej ostatniej. Wiedza na temat kulturowych modeli kobiecości i męskości, rozróżnienie między płcią biologiczną (sex) i kulturową (gender) uświadamia ludziom, że stawiane im jako kobietom i mężczyznom, matkom i ojcom, oczekiwania mają charakter społeczny, a nie wynikają z „naturalnych” różnic. A skoro ,autorem” definicji kobiecości i męskości, macierzyństwa i ojcostwa jest społeczeństwo, nie natura, to nie są one stałe, nienaruszalne i można je zmienić.

Nowoczesny model kobiecości i męskości odrzuca dualizm płci. Jak pisze E. Pakszys, ,[...] dychotomii, polaryzacji-przeciwstawia się stopniowalnośći ciągłość, gdzie między biegunowymi skrajnościami jest miejsce dla licznych odcieni, innych konfiguracji i kombinacji, na przykład coś jest niżej lub wyżej, dalej lub bliżej; coś jest bardziej lub mniej słodkie albo gorzkie, ciepłe lub zimne (od czegoś innego). [...] Problem pojawia się wobec wartości i cech złożonych lub «uogólnionych», zwłaszcza w odniesieniu do człowieka. Czy zatem właściwe jemu/jej charakterystyki rodzajowe mogą podlegać stopniowaniu, gradacji?" (Pakszys 2000: 121). Według Sandry L. Bem mogą, co badaczka udowadnia, proponując Inwentarz do Badania Płci Psychologicznej (Bem 2000: 117). U podstaw stworzenia Inwentarza leżało założenie, że nie wszyscy ludzie są „typowi płciowo”, tj. „mają 
silną motywację do podtrzymywania zgodności wizerunku własnego z kulturową definicją płci”, istnieją także osoby androgyniczne, „dla których kulturowe standardy płci nie stanowią punktu odniesienia" (Gębala 2007: 22). Jak stwierdza Eugenia Mandal, „Sandra Bem, nawiązując do starożytnego mitu trzeciej płci - Androgyny, w sposób rewolucyjny zakwestionowała tradycyjne przekonanie o dychotomii płci. [...]. Miast jak dotąd ujmować płeć jako dychotomiczną zmienną, Bem potraktowała ją jako zmienną o ciągłym charakterze pozwalającą opisywać zachowanie jednostki na dwóch rozległych wymiarach: męskości i kobiecości” (Mandal 2005: 39). Wymiary te nie są traktowane jako przeciwległe bieguny jednej osi, ale dwie odrębne skale, dzięki czemu badany może osiągnąć jednocześnie wysoką lub niską punktację zarówno przy cechach męskich, jak i kobiecych, bądź wysoką punktację przy jednych cechach, a niską przy drugich (Bem 2000: 117). Występujące w teście właściwości kobiece i męskie odpowiadają stereotypom płciowym. W zależności od nasilenia cech na dwóch skalach, możemy mieć do czynienia z osobowością męską (wysoka męskość, niska kobiecość), kobiecą (niska męskość, wysoka kobiecość), androgyniczną (wysoka męskość, wysoka kobiecość) lub nieokreśloną (niska męskość, niska kobiecość) (Bem 2000: 117).

Zdaniem Przemysława Gębali, w nowoczesnym społeczeństwie powstają sprzyjające warunki dla rozwoju cech androgynicznych, ,ponieważ pluralizacja prowadzi do poszerzenia przestrzeni społecznej o te wartości, które w tradycyjnym rozumieniu lokowały się na marginesie kultury, będąc definiowane jako przejawy transgresji lub dewiacji” (Gębala 2007: 24). Według Zenona W. Dudka osoby o „mieszanej płci psychologicznej” mają nawet wyższą pozycję społeczną w zmieniającej się społecznej rzeczywistości, co można, prawdopodobnie, wyjaśniać ich większą elastycznością, umiejętnością dostosowywania się, otwartością (w przeciwieństwie do typów skrajnych - albo tylko męskich, albo tylko kobiecych) (Dudek 2007: 72).

Nowoczesny model płci nie tylko „uwalnia” kobiecość i męskość ze sztywnych, gotowych, ograniczających indywidualność schematów, oznacza także wyzwolenie z norm dotyczących seksualności (Arcimowicz 2008a: 48; 2010: 14; Giddens 2006). Podczas gdy w tradycyjny model kobiecości i męskości wpisane było uprzywilejowanie heteroseksualizmu (określane dziś jako „heteroseksizm”), (Bem 2000: 84), nowe spojrzenie na płeć pociągnęło za sobą przyzwolenie na posiadanie innej niż heteroseksualna tożsamości seksualnej, „depatologizację homoseksualizmu" (tamże: 99). Coraz więcej osób ma odwagę publicznie ujawnić swoją orientację homoseksualną (Gergen 2009: 178). Rozwijają się studia lesbijsko-gejowskie (LGTB - Lesbian, Gay, Bisexual, Transsexual/Transgender) i teoria queer ${ }^{2}$, w ramach których pokazuje się, że podobnie jak płeć, tak i seksualność

${ }^{2} \mathrm{~W}$ języku polskim brakuje odpowiednika terminu queer, co wiąże się z dominacją w dyskursie publicznym negatywnych określeń osób homoseksualnych czy transseksualnych (Mizielińs- 
człowieka jest konstruktem społecznym: społeczeństwo definiuje i narzuca jednostkom reguły bycia kobietą/mężczyzną oraz normę heteroseksualności, ograniczając ich możliwość „bycia sobą” (Kochanowski 2009: 21, 36; Jarymowicz 2007: 47). Podkreśla się przy tym wzajemne powiązanie tych kategorii: w świetle tradycyjnego modelu płci, bycie kobietą i bycie mężczyzną zawierało w sobie normę heteroseksualności. Nowoczesny model płci odrzuca zarówno konieczność bycia „kobiecą kobietą" i „męskim mężczyzną”, dopuszczając bycie „męską kobietą”, „kobiecym mężczyzną”, osobą androgyniczną czy nieokreśloną płciowo, jak i neguje konieczność bycia osobą heteroseksualną, umożliwiając istnienie innych orientacji seksualnych. W refleksji teoretycznej pojawiają się pojęcia transgenderyzmu oraz transseksualizmu ${ }^{3}$, określające przekraczanie norm związanych z płcią, dotyczące osób nieutożsamiających się z własną płcią biologiczną, ,uwięzionych we własnym ciele" (Bieńkowska-Ptasznik 2007; 2011: 460). Zjawisko transseksualizmu jest dowodem na to, że skoro w ciele mężczyzny może być zamknięta kobieta (lub odwrotnie), cechy biologiczne są wątpliwym kryterium oceny płci (Gergen 2009: 178). Używa się także określenia „trzecia płeć”, by pokazać, że jednostka nie musi mieścić się w binarnym systemie kobiecość - męskość (albo kobieta albo mężczyzna) (Bradley 2008: 32; Bieńkowska-Ptasznik 2007). Badacze, przywołując przykłady różnych kultur - dawnych i współczesnych - w których funkcjonują „,alternatywne” wzory kobiecości i męskości, dowodzą, że ,[...] binaryzm płci kulturowej nie jest uniwersalny, a dominująca w kulturze zachodniej koncepcja dymorfizmu genderowego nie jest koncepcją jedyną możliwą. Znane są społeczeństwa, które wypracowały system polimorficzny: trzech, a nawet czterech płci kulturowych" (Arcimowicz 2008b: 198).

Wyniki badań nad stereotypami płci pokazują, że coraz mniej akcentowane są w nich różnice między kobiecością i męskością (Diekman, Eagly 2000, za: Wojciechowska 2002: 160). Może to być wynik tego, że „obie płcie stały się bardziej androgyniczne: kobiety uaktywniły w sobie cechy męskie, a mężczyźni kobiece” (Sikora 2008: 322). Zdaniem Renaty Siemieńskiej, powolna erozja stereotypów płci jest rezultatem dysponowania przez przedstawicieli obu płci podobnym kapitałem kulturowym (w związku ze wzrostem wykształcenia kobiet i ich działalnością w sferze publicznej) oraz pogłębiającej się wspólnoty doświadczeń (Siemieńska 2007a: 320, 341; 2007b: 307). „Coraz więcej preferencji, predyspozycji

ka 2006: 123, za: Kochanowski 2009: 39). W uproszczeniu, przedmiotem zainteresowania teorii queer są jednostki i kategorie społeczne „niemieszczące się” w dominujących normach płci i/lub seksualności (Kochanowski 2010). W literaturze przedmiotu pojawiają się próby nazywania teorii queer teorią odmienności (Ciaputa 2011: 438).

3 Jak podaje Sally Hines, „, [...] «transgender» jest zbiorczym terminem obejmującym osoby transgenderowe, transseksualne, bigenderowe oraz interseksualne, transwestytów, cross-dressers, drag kings i drag queens. "Transseksualny» odnosi się do ludzi , którzy zmieniają swoją płeć anatomiczną za pomocą hormonów i/lub metod chirurgicznych" (Hines 2008: 99). 
uważa się za charakterystyczne dla człowieka jako takiego, za niezwiązane z faktem bycia kobietą bądź mężczyzną" (Siemieńska 2007a: 320). Według Zbyszka Melosika, to rynek oraz media, przede wszystkim reklamy, „zrównują” kobiecość i męskość - „obie płcie są traktowane jako uprzedmiotowione obiekty podporządkowania i manipulacji” i obu na równi oferuje się „różnorodne zestawy tożsamości” (Melosik 1996: 228, za: Dziekanowska 2008: 62). Badacze mówią o ,uniseksualizacji” (Minkiewicz 2006: 203), „unifikacji ról” kobiety i mężczyzny” (Gębuś 2006: 46; Duch-Krzystoszek 1996: 86), „końcu binaryzmu płci” (Melosik 2002: 27). Wiąże się to przede wszystkim ze zmianą w obrębie stereotypu kobiecości, pojawieniem się $\mathrm{w}$ nim cech instrumentalnych, co z kolei jest konsekwencją masowej aktywności zawodowej kobiet (Wojciechowska 2002: 160). Przejawy „upodabniania się" kobiet i mężczyzn w perspektywie historycznej analizowała Maria Bogucka, wskazując m.in. na zmiany w modzie jako ,wizualny znak” przemian w sferze obyczajowej (Bogucka 2005: 298). Autorka zwróciła uwagę na rezygnację $\mathrm{z}$ atrybutów płci w ubiorze i pojawienie się jednakowej odzieży dla obu płci (,unisex”), „feminizację wyglądu mężczyzn (długie włosy, kolczyki, łańcuszki, bransoletki)” oraz „maskulinizację wyglądu kobiet” - „chłopczyce z obciętymi włosami” (Bogucka 2005: 280, 299). O „strojeniu i perfumowaniu męskości” pisze także Zbyszko Melosik (Melosik 2002: 27). Przejawem depolaryzacji płci jest również wkraczanie kobiet $\mathrm{w}$ dziedziny zarezerwowane dla mężczyzn i przez nich zdominowane, takie jak sport (w tym takie dyscypliny jak zapasy, podnoszenie ciężarów, piłka nożna czy boks), wojsko, nauka i sztuka, wreszcie kapłaństwo (Bogucka 2005: 299, 305-312)

W ramach nowoczesnego modelu płci zauważono i uprawomocniono podobieństwo między kobietami i mężczyznami także w zakresie seksualności (Flood 2008: 271; Giddens 2006: 16). Rewolucją w sferze życia seksualnego była społeczna akceptacja czerpania przez kobiety przyjemności z aktu seksualnego, gdyż do tej pory ich rolę ograniczano do zaspokajania potrzeb mężczyzny, a przede wszystkim do prokreacji (Bogucka 2005: 280-281). Cieszenie się życiem seksualnym, bez lęku przed niechcianą ciążą, było możliwe dzięki upowszechnieniu dostępu do antykoncepcji. Nad seksualnością kobiet nie wisi już „fatum macierzyństwa” (Beck 2002: 171). Anthony Giddens mówi o „narodzinach plastycznej seksualności”, „wyzwolonej” od wymogu prokreacji, heteronormatywności oraz różnych standardów obowiązujących kobiety i mężczyzn w modelu tradycyjnym (Giddens 2008: 11, 25, 27, 41). „Seksualność staje się zjawiskiem płynnym. [...], plastyczną, poddającą się modelowaniu, potencjalną «własnością» jednostki" (tamże: 25, 40). Kobiety zyskują kontrolę nad własną seksualnością i uwalniają się od dominacji mężczyzn w sferze seksualnej. Społecznie piętnuje się takie zjawiska jak molestowanie seksualne oraz gwałt, w tym gwałt małżeński, a także pornografię, „która w jaskrawej formie przedstawia męską dominację, przemoc i podporządkowanie kobiety, traktując jej ciało jako towar dostępny dla każdego klienta" (Bogucka 2005: 303, 304). Zda- 
niem M. Boguckiej, o „postępującej niwelacji różnic społecznych między obu płciami” świadczą także takie zjawiska jak męska pornografia oraz męska prostytucja (Bogucka 2005: 304).

Nowoczesny model płci niesie ze sobą zmianę relacji między kobietami i mężczyznami na różnych płaszczyznach życia społecznego, w tym w sferze prywatnej. Mówi się o „poszukiwaniu «nowego przymierza»” między płciami, „renegocjacji kontraktu płci” czy budowaniu „nowego kontraktu płci”, demokratyzacji rodziny, partnerstwie itp. (Krzyszkowski 1989; Walczewska 2000; Fuszara 2002; Giza-Poleszczuk 2004; Giddens 2006; Ronek 2008; Zygmunt 2009). Ponieważ w warunkach refleksyjnej nowoczesności jednostki przestają być wykonawcami społecznych przepisów i scenariuszy, muszą uzgadniać między sobą swoje zachowania, układać dopiero swoje wzajemne relacje. Wymaga to asertywności, umiejętności dyskutowania o swoich potrzebach, pragnieniach, odczuciach oraz nastawienia na współpracę i osiągnięcie kompromisu. Obserwujemy ,[...] przejście od regulacji wzajemnych stosunków w oparciu o autorytaryzm i podporządkowanie do relacji opartych na negocjacjach. Takie przejście jest najbardziej wyraźne w relacjach intymnych między kochankami, małżonkami, rodzicami i dziećmi”" (Torrance 1998: 9, za: Kwak 2005: 24). Jednostki tworzą ,negocjowane rodziny” (Beck, Beck-Gernsheim 1995; 1997; 2002, za: Kwak 2005: 32). Zdaniem A. Giddensa, efektem procesu indywidualizacji, wzrostu podmiotowości i wolności człowieka jest powstanie „czystej relacji”, rozumianej przez niego jako ,istniejąca dla niej samej”, tworzona i podtrzymywana przez partnerów tylko dla odnoszonych przez nich korzyści (Giddens 2001b: 124; 2006: 75). Odczuwanie satysfakcji ze związku z drugą osobą wymaga wspólnego wynegocjowania jego zasad: „«Udział jednostek w ustalaniu warunków ich współistnienia» to ideał czystej relacji" (Giddens 2006: 224). Autor przyrównuje proces demokratyzacji rodziny do demokratyzacji w sferze publicznej, oba bowiem opierają się na tych samych zasadach: autonomii i równości jednostek, otwartej komunikacji, wolności od przemocy (Giddens 1999: 84). Jak podkreśla A. Giddens, ,przede wszystkim, i jest to sprawa fundamentalna, musimy wyjść od zasady równości płci, od której nie może być odwrotu" (tamże). Włączenia zasad sprawiedliwości i równości społecznej do życia rodzinnego, traktowanego przez długi czas jako prywatne, a zatem apolityczne, domagały się feministki (,prywatne jest polityczne”), traktując to jako warunek osiągnięcia równego statusu kobiet i mężczyzn w społeczeństwie (Zygmunt 2009: 38, 39). Idea „sprawiedliwości między płciami” (gender justice) obejmuje wszystkie sfery życia społecznego (Putnam Tong 2002: 47; Kwiatkowska, Nowakowska 2006: 28).

Mimo że nowoczesny model płci niesie za sobą wolność od jakichkolwiek schematów, zostawia jednostce wybór jaka ma być i umożliwia istnienie wielu odmian bycia kobietą/mężczyzną, można podjąć próbę określenia „nowej” kobiecości i męskości. 
„Nowoczesna” kobiecość wychodzi poza schemat, określany w języku niemieckim jako Kirche - Küche - Kinder ${ }^{4}$, wiąże się z przyznaniem kobietom prawa do aktywności poza domem, podejmowania ról pozostających do tej pory domeną mężczyzn. Betty Friedan w swojej książce The Feminine Mistique (1963) pokazała frustrację kobiet „skazanych” na domowe więzienie przez społeczeństwo, oczekujące od nich bycia przede wszystkim żoną i matką (Friedan 2013; Bogucka 2005: 292-293; Bobako 2010: 236). Według tej feministycznej autorki, „aktywność w sferze zawodowej, twórcze działanie poza domem miało zapewnić kobietom poczucie pełni i indywidualnej autonomii, a tym samym przyczynić się do realizacji ideału równości płci" (Bobako 2010: 237). Zmiana pozycji kobiety w społeczeństwie jest wynikiem takich makrospołecznych procesów, jak industrializacja i urbanizacja oraz demokratyzacja społeczeństw, a także wspominanej działalności ruchu feministycznego (Beck 2002; Malinowska 2000; Slany 2008). Proces indywidualizacji i wzrost podmiotowości doprowadziły do wzrostu dążeń emancypacyjnych kobiet, przyznania im prawa do orientacji na siebie, dowartościowania ich osobistych potrzeb, pragnień, aspiracji (tamże). W wyniku masowej obecności kobiet na rynku pracy do tradycyjnego repertuaru ról kobiecych obejmującego role żony, matki i gospodyni domowej włączona została rola kobiety pracownika. Innym czynnikiem mającym kluczowe znaczenie dla kształtowania się nowych definicji kobiecości i macierzyństwa jest rozwój medycyny i pojawienie się rozmaitych możliwości kontroli urodzeń. Dzięki coraz większej wiedzy na temat różnych metod antykoncepcji i coraz szerszemu dostępowi do nich, „macierzyństwo nie jest już obowiązkowe ani nieuchronne” (Servan-Schreiber 1998: 173). Możliwości kontrolowania płodności otwierają kobietom drogę do realizowania kobiecości nie tylko poprzez macierzyństwo. Jak zauważa Krystyna Slany, „następuje przeorientowanie młodych kobiet na coraz ważniejsze dla nich cele edukacyjne i zawodowe" (Slany 2008: 111). A zatem jednym z możliwych wariantów wpisanych w nowoczesne definicje kobiecości i męskości może być ich konstruowanie z pominięciem ról biologicznych, rodzicielskich.

Przemianom kulturowego modelu kobiecości towarzyszą zmiany modelu męskości, gdyż „kategorie te są konstruowane w relacji do siebie - zdefiniowanie jednej z nich wpływa na definicję drugiej”, zmiany w obrębie jednej wywołują zmiany w tej drugiej (Kimmel 1987). Zdaniem U. Becka, ,istotne impulsy do wyswobodzenia się z roli mężczyzny nie mają mimo wszystko immanentnego charakteru, są on indukowane z zewnątrz (przez zmianę sytuacji kobiet)" (Beck 2002: 174). W wyniku pracy zawodowej mężczyźni „zwalniani są” z roli jedynego żywiciela rodziny i mogą (a nawet muszą - wobec oczekiwań partnerek) zaangażować się w życie rodzinne. Nowa koncepcja męskości wiąże się z odrzuceniem wizerunku mężczyzn jako chłodnych i zamkniętych emocjonal-

\footnotetext{
${ }^{4} \mathrm{Z}$ j. niemieckiego: kościół - kuchnia-dzieci.
} 
nie oraz ich zwróceniem ku rolom ekspresyjnym. Teraz mogą oni bez przeszkód wyrażać własne uczucia, emocje i pragnienia (Arcimowicz 2003: 57). Zdaniem Michaela Flooda, analizującego przemiany seksualności, „dają się zauważyć pewne oznaki przesuwania się mężczyzn w stronę tradycyjnie bardziej kobiecych form zaangażowania seksualnego i intymnego", opartych na romantycznej miłości i zaufaniu (Flood 2008: 271-272). Można spotkać się z określeniem „miękkiego mężczyzny” (soft man) czy mężczyzny metroseksualnego (Szarzyńska 2005: 50; Arcimowicz 2008a: 43-44; Sikora 2008: 322; Dziekanowska 2008: 62). „Cechuje go kobieca delikatność i wrażliwość, oczekuje się od niego troski, opiekuńczości, partnerskiego stosunku do kobiet, przy równoczesnej sile psychicznej i koncentracji na pracy, jako nadal najważniejszym komponencie męskiej samooceny" (Dziekanowska 2008: 63). Jak zauważa E. Badinter, system patriarchalny okaleczał mężczyzn, wymagając od nich odrzucenia kobiecego pierwiastka w samym sobie i thumiąc tym samym część ich osobowości (Badinter 1993: 113, 114). „Nowy mężczyzna” jest „pogodzony z samym sobą”, akceptuje swoją wewnętrzną kobiecość i pozwala jej się ujawniać (tamże: 144). Znajduje to wyraz nie tylko w jego większej wrażliwości, uczuciowości, czułości, ale także w dbałości o wygląd ${ }^{5}$. To nowe podejście mężczyzny do własnej cielesności Zbyszko Melosik nazywa „feminizacją męskiego ciała” (Melosik 2002: 21). Autor zauważa, że w tradycyjnym modelu płci cielesność mężczyzny nie miała znaczenia: ,[...] miało się wrażenie, że jedynie kobieta posiada ciało, które mężczyzna podziwia i zdobywa. Ona była ciałem, on - umysłem i intelektem”. W nowoczesnym modelu, wobec „media-izacji” męskości - propagowania $\mathrm{w}$ środkach masowego przekazu pożądanego wizerunku mężczyzny (młodego, wysokiego, szczupłego, opalonego, jednym słowem: pięknego), także męskie ciała stają się obiektem zainteresowania oraz seksualnego pożądania, obowiązują je nakazy bycia atrakcyjnym, zadbanym, modnie ubranym (tamże: 22). Anna Barabasz zwraca uwagę, że w refleksji nad „nowoczesną” męskością, w związku z negatywnymi społecznymi ocenami mężczyzn metroseksualnych jako zniewieściałych i o niewiadomej orientacji seksualnej, pojawiło się pojęcie mężczyzny überseksualnego (Barabasz 2007: 150). Odpowiada ono męskości androgynicznej, czyli harmonijnemu połączeniu cech uznawanych za kobiece i męskie, a zatem z jednej strony czułości i empatii, z drugiej - siły, aktywności, stanowczości oraz podkreślaniu męskości w wyglądzie (,zamiast godzinami wklepywać krem pod oczy, pielęgnuje zarost”) (tamże).

5 Jak zauważa Aleksandra A. Winiarska, dbałość o wygląd przez mężczyzn nie jest czymś zupełnie nowym w kulturze europejskiej (2008: 28). Autorka przypomina ideał „kalokagatii” ze starożytnej Grecji, nakazujący być „,dobrym i pięknym”, czy dandyzm w środowiskach artystycznych XIX wieku. Jej zdaniem „współczesny mężczyzna metroseksualny wydaje się zatem stanowić nawiązanie do ideałów męskości znanych nam już z historii Europy” (tamże). 
Akceptacja w sobie tego co kobiece przez mężczyzn wiąże się $\mathrm{z}$ akceptacją kobiecości w ogóle, „zrównania” jej z tym, co męskie. A zatem nowoczesny model męskości opiera się na neutralnym, wolnym od wartościowania postrzeganiu cech, ról, płaszczyzn określanych w tradycyjnym ujęciu jako kobiece/męskie. Stąd mowa o „nieseksistowskim”, „sfeminizowanym” mężczyźnie (Bradley 2008: 70). Rodzinny terapeuta, Steve Biddulph, omawiając „kroki do męskości”, czyli „etapy pełnego rozwoju mężczyzny”, wymienia „traktowanie partnerki na równych prawach" (Biddulph 2004: 27). Tego typu poradniki świadczą o konieczności resocjalizacji męskiej części populacji, „przyzwyczajonej” do patriarchalnej tradycji.

Podsumowując charakterystykę nowoczesnego modelu płci, warto zestawić go z modelem tradycyjnym, są to bowiem dwa przeciwstawne sposoby postrzegania kobiecości i męskości. W tabeli 2 przedstawiono najważniejsze elementy, w których ujawniają się różnice między modelami. Dotyczą one sposobu wyjaśniania różnic między kobietami i mężczyznami, definiowania cech i ról płciowych oraz relacji między płciami, postrzegania wpływu społecznego na tożsamość płciową jednostki, wreszcie norm dotyczących seksualności.

Tabela 2. Porównanie tradycyjnego i nowoczesnego modelu płci

\begin{tabular}{|l|l|}
\hline \multicolumn{1}{|c|}{ Tradycyjny model płci } & \multicolumn{1}{c|}{ Nowoczesny model płci } \\
\hline $\begin{array}{l}\text { Determinizm i naturalizm w określaniu } \\
\text { kobiecości i męskości }\end{array}$ & $\begin{array}{l}\text { Kulturowe pochodzenie modeli i wzorów } \\
\text { kobiecości i męskości }\end{array}$ \\
\hline $\begin{array}{l}\text { Dychotomia: podział cech i ról na kobiece- } \\
\text { męskie }\end{array}$ & $\begin{array}{l}\text { „Płciowa neutralność” cech i ról; } \\
\text { wymienność }\end{array}$ \\
\hline $\begin{array}{l}\text { Dwie płcie - albo kobieta albo mężczyzna; } \\
\text { sztywny schemat - brak wyboru }\end{array}$ & $\begin{array}{l}\text { Różne formy kobiecości i męskości; } \\
\text { androgyniczność; swoboda wyboru zachowań } \\
\text { związanych z płcią }\end{array}$ \\
\hline Narzucona kolektywna tożsamość płciowa & $\begin{array}{l}\text { Podmiotowa tożsamość kobiet i mężczyzn } \\
- \text { indywidualny projekt tożsamości }\end{array}$ \\
\hline $\begin{array}{l}\text { Dominacja - podporządkowanie w relacji } \\
\text { płci; nierówność płci }\end{array}$ & Partnerstwo i równość płci \\
\hline $\begin{array}{l}\text { Konflikt płci - ,asymetryczny” kontrakt płci } \\
\text { (narzucany przez społeczny porządek) }\end{array}$ & $\begin{array}{l}\text { Nowy kontrakt płci (efekt negocjacji między } \\
\text { wchodzącymi w relację jednostkami) }\end{array}$ \\
\hline $\begin{array}{l}\text { Heteroseksualność } \\
\text { Różne opcje seksualności, ,„seksualny } \\
\text { pluralizm” }\end{array}$ \\
\hline $\begin{array}{l}\text { Normy dotyczących zachowań seksualnych, } \\
\text { inne dla kobiet, inne mężczyzn }\end{array}$ & $\begin{array}{l}\text { Swoboda seksualna kobiet i mężczyzn; } \\
\text { podobieństwo w zakresie seksualności }\end{array}$ \\
\hline
\end{tabular}

Źródło: Opracowanie własne. 
Jak wynika z dotychczasowych rozważań, nowoczesny model kobiecości i męskości nie ogranicza jednostek, daje im wolność w wyrażaniu siebie, pozwala na budowanie kobiecej/męskiej tożsamości w zgodzie z własnymi przekonaniami, wartościami, predyspozycjami. Odpowiada to Giddensowskiej polityce życia - polityce samorealizacji. Podmiotowość kobiet i mężczyzn wyraża się w możliwości odrzucenia gotowych schematów ról płciowych i norm seksualności, negocjowania i tworzenia nowego kontraktu płci, satysfakcjonującego dla każdej ze stron.

\subsection{Macierzyństwo i ojcostwo w nowoczesnym modelu kobiecości i męskości}

Nowoczesny model płci kulturowej opiera się na równości i partnerstwie kobiet i mężczyzn, które to wartości odnoszą się do wszelkich relacji między płciami, także do rodzicielstwa. Oznacza to, że oboje małżonkowie - rodzice mają takie same możliwości aktywności w sferze prywatnej i pozadomowej (Jump, Haas 1987: 98; Johansson, Klinth 2008: 57). A zatem oczekuje się od mężczyzny zaangażowania w życie rodzinne i równego podziału obowiązków domowych i rodzicielskich między oboje partnerów. Przy czym męskiej aktywności nie traktuje się jako wsparcia czy pomocy dla kobiety, lecz jako współodpowiedzialność (Johansson, Klinth 2008: 57). „Demokratyczne stosunki rodzinne zakładają wspólną odpowiedzialność za opiekę nad dziećmi, zwłaszcza równe rozłożenie obowiązków między kobiety i mężczyzn [...]" (Giddens 1999: 85). Mikołaj Gębka przywołuje pojęcie ,symetrycznego dwurodzicielstwa” oznaczającego włączenie obojga rodziców na równych prawach w opiekę nad dzieckiem i nawiązywanie równie silnej więzi z dzieckiem przez matkę i ojca (Gębka 2007: 92). Podkreśla się korzyści takiej równowagi ról dla dzieci, kobiet oraz samych mężczyzn (Jump, Haas 1987: 98).

Podobnie jak kobiecość i męskość, tak również macierzyństwo i ojcostwo traktowane są na gruncie nowoczesnego modelu płci jako społeczne konstrukty (Beall 2002: 86; Renzetti, Curran 2005: 93-94). Zdaniem Ruth Bleier, mimo że role rodzicielskie opierają się na biologicznej zdolności do reprodukcji, natura w żaden sposób nie determinuje sposobu ich realizacji, podobnie jak innych społecznych ról: „Pielęgnacja i opieka na dzieckiem jest w takim samym stopniu funkcją czynników kulturowych, społecznych, politycznych, ekonomicznych, co biologicznych. I dotyczy to nie tylko roli matki [oraz ojca - K.D.-G.], a także poety czy piłkarza" (Bleier 1984: 146, za: Renzetti, Curran 2005: 94). Dowodów na kulturowe uwarunkowania sposobu realizowania ról rodzicielskich dostarczają badania historyczne oraz międzykulturowe (Mead 1949, za: Budrowska 2000: 35; Mead 1986; Delumeau, Roche 1995; Badinter 1998; Renzetti, Curran 2005). Jak stwierdza Margaret Mead, „[...] pytanie o to, czy matka będzie, czy też nie 
najważniejszą osobą w środowisku dziecka, jest pytaniem natury społeczno-kulturowej, a nie biologicznej. [...] w innych kulturach z powodzeniem funkcjonowały rozmaite rodzaje opieki nad dzieckiem" (Mead 1949, za: Budrowska 2000: 35). Macierzyństwo nie musi oznaczać całkowitego poświęcenia się wychowywaniu dzieci i rezygnacji z innych rodzajów aktywności, podobnie ojcostwo nie musi sprowadzać się do materialnego zabezpieczenia rodziny i roli surowego wychowawcy. Elisabeth Badinter, analizując różne postawy matek na przestrzeni wieków, wykazała, że ,instynkt macierzyński” pojmowany jako chęć posiadania dziecka przez kobietę oraz jej bezwarunkowa i natychmiastowa miłość do dziecka to mit, którego nie da się obronić wobec danych o kobietach przerywających ciążę, porzucających czy zabijających swoje potomstwo (Badinter 1998). Zdaniem Sally Macintyre, tradycyjne podejście do macierzyństwa to przykład ,społecznego fabrykowania «instynktów»" (1982). Jak stwierdza Marianna Dąbrowska-Wnuk, „obalenie pewnego mitu, zgodnie z którym wyłącznie matki - z racji uwarunkowań biologicznych - są w stanie sprawować opiekę nad dzieckiem, do pewnego stopnia wyrównało szanse obojga rodziców" (Dąbrowska-Wnuk 2007: 135).

Androgyniczność oraz unifikacja, upodabnianie się do siebie ról kobiet i mężczyzn w nowoczesnym modelu płci dotyczy także rodzicielstwa - odchodzi się od specjalizacji roli matki i ojca, zakładając podobieństwo ich cech, zadań i relacji z dzieckiem (Gębuś 2006: 57-58; Sikorska 2009a: 196). „Najczęściej wspólnie pracują na utrzymanie rodziny, wspólnie prowadzą gospodarstwo domowe, wspólnie też troszczą się o rozwój dzieci, otaczając je miłością i opieką" (Gębuś 2006: 57-58). Przyjmuje się przy tym, że mężczyźni są równie kompetentnymi rodzicami jak kobiety (Jump, Haas 1987: 99). To „scalenie” macierzyństwa i ojcostwa skłania do mówienia o rodzicielstwie, zamiast o każdej z ról z osobna.

Dzięki androgyniczności jednostek oboje rodzice mogą być ,kobiecy” lub „męscy” w zależności od sytuacji (Badinter 1993: 148). „Ojciec może być kolejno kobiecy przy małym dziecku i zdecydowanie męski, gdy ono podrośnie. Najpierw niańczy, a następnie uczy grać w rugby" (Badinter 1993: 148; Dziekanowska 2008: 65). Jednak, co podkreśla E. Badinter, nie oznacza to totalnego zatarcia różnic między płciami oraz rodzicami różnej płci: „Niewątpliwie nigdy mężczyzna i kobieta nie byli podobniejsi, nigdy rodzaje nie były mniej różne niż obecnie. Podobieństwo to jednak nie tożsamość i subtelne różnice nadal istnieją. Dzieci zawsze je w końcu wykrywają u swoich androgynicznych rodziców" (Badinter 1993: 148). Autorka zauważa na przykład, że kobiety i mężczyźni nie różnią się jeżeli chodzi o ,pokłady” opiekuńczości wobec dzieci, czego dowodzą chociażby badania przeprowadzane wśród ojców pełniących rolę głównych czy jedynych opiekunów (tamże: 153). Natomiast zauważalne różnice między rodzicami dotyczą m.in. sposobów bawienia się z dzieckiem, bardziej stymulujących, żywszych, opartych na fizycznym kontakcie w przypadku mężczyzn (tamże: 155).

Brak wyraźnego podziału ról pociąga za sobą konieczność negocjowania, uzgodnienia, na czym polegać ma w danym układzie rola matki i rola ojca, zwery- 
fikowania wyobrażeń kobiety i mężczyzny dotyczących ich rodzicielstwa i dopasowania ich do siebie. Może to przyjmować formę wyznaczenia konkretnych zadań każdemu z rodziców lub przyjęcia zasady wymienności, zastępowalności przy określonych czynnościach i nieprzypisywaniu ich ,raz na zawsze” jednej osobie. „Podział ról może wynikać z wielu czynników: predyspozycji osobowościowych, umiejętności wykonywania danych czynności, czasu poświęcanego pracy zawodowej, kompromisu zawartego między małżonkami” (Gębuś 2006: 57-58).

Nowoczesne rodzicielstwo wymaga odpowiedniego przygotowania zarówno kobiet, jak i mężczyzn do opieki nad dziećmi. Rodzina staje się królestwem dziecka (king child with parents) (Slany 2008: 106). Celem rodziców jest posiadanie „dziecka wysokiej jakości”, co wymaga różnego rodzaju nakładów i inwestycji, w tym także poświęcanego mu czasu i opieki ze strony i matki i ojca (Giza-Poleszczuk 2002b: 294). Bogusława Budrowska określa wymagania stawiane współczesnym rodzicom w następujący sposób: „metody wychowywania dzieci określane jako właściwe są: skoncentrowane na dziecku, oparte na autorytecie ekspertów, absorbujące emocjonalnie, wymagające intensywnej pracy i kosztowne finansowo" (Budrowska 2000: 166). O posiadaniu ,dobrze urodzonego dziecka" (określenie Włodzimierza Fijałkowskiego) decyduje także wspólne uczestnictwo obojga rodziców w przygotowaniach do narodzin potomka i rodzinny poród (Regosz-Kaczkowska, Minkowski 2000: 35). Dziecko jest „,projektem” realizowanym przez rodziców w oparciu o wiedzę ekspercką, dotyczącą najdrobniejszych szczegółów na kolejnych etapach życia dziecka (Olcoń-Kubicka 2009: 35; Urbańska 2009; 2012). Można mówić o ,profesjonalizacji” czy „ekspertyzacji” macierzyństwa i ojcostwa, które tracą swój „,naturalny” charakter (tamże). Powstał wokół nich szeroki dyskurs poradnikowy, obejmujący książki, czasopiśmiennictwo, programy telewizyjne oraz szkolenia dla rodziców. Organizatorzy zajęć dla ojców uzasadniają ich tworzenie koniecznością przygotowania mężczyzn do bycia rodzicem, przyrównując ojcostwo do zawodowej specjalizacji (dotyczy to także macierzyństwa - Urbańska 2009: 37): „Bycie tatą, jak każda dziedzina życia wymaga rzetelnej wiedzy i pracy nad własną osobowością" (http://www. tato.net, 29.09.2015). Odrzuca się założenie o posiadaniu „,naturalnych”, wrodzonych rodzicielskich kompetencji, a także możliwość opierania się na wiedzy potocznej własnych rodziców czy innych osób w otoczeniu (jako wiedzy ,nierzetelnej”). Podobnie, popularność szkół rodzenia przygotowujących oboje rodziców, a przede wszystkim matki, do porodu, połogu oraz opieki nad noworodkiem może dowodzić, że młodzi rodzice potrzebują ,profesjonalnego wsparcia”, nie chcą polegać na intuicji, a wiedzę starszych członków rodziny, także tych mających „odchowane" już dzieci traktują jako zdezaktualizowaną. Poszukiwanie informacji dotyczących opieki nad dzieckiem, dzielenie się poglądami, doświadczeniami, problemami, poradami między matkami i ojcami na forach internetowych można traktować jako wyraz refleksyjności nowoczesnych rodziców (Williams 2008; O1coń-Kubicka 2009: 42; Kubicki 2009: 91). 
Jak zostało to już podkreślone, nowoczesny model płci umożliwia jednostkom wybór sposobu bycia i tożsamości. Macierzyństwo i ojcostwo przestają być obowiązkowe, nie są koniecznym, nieodłącznym elementem kobiecości i męskości. Odwołując się do słów Ruth Bleier: „należy pamiętać, że - przeciwnie niż dzieje się to w wypadku oddychania - biologiczna zdolność do posiadania potomstwa nie oznacza konieczności reprodukcji lub nawet podejmowania heteroseksualnej aktywności” (Bleier 1984: 146, za: Renzetti, Curran 2005: 94). Owa nieobowiązkowość macierzyństwa oraz ojcostwa znajduje wyraz w zjawisku dobrowolnej bezdzietności (Slany 2008: 110). „Następuje negacja macierzyństwa/rodzicielstwa jako swego rodzaju «powinności biologicznej», a plany życiowe koncentrują się wokół wartości postrzeganych jako wyższe: naukowych, artystycznych, literackich itp.” (Sobczyńska 1995: 75). Kolejną ,nowością” jest - dotyczące jedynie kobiet - samotne rodzicielstwo z wyboru, możliwe dzięki sztucznemu zapłodnieniu, odsuwającemu mężczyzn od udziału w prokreacji (Piątek 2007: 96). Jak zauważa Renata Siemieńska, powołując się na międzynarodowe badania systemów wartości, wrasta społeczne przyzwolenie na macierzyństwo poza trwałym, zalegalizowanym związkiem z ojcem dziecka: „,...] zwiększyła się liczba osób, zwłaszcza kobiet, które dopuszczają sytuację, w której «kobieta ma prawo chcieć mieć dziecko nie wiążąc się na stałe z mężczyzną». Wzrasta przekonanie o prawie jednostki do pewnej autonomii" (Siemieńska 2007b: 313).

Model Matki Polki podlega transformacji (Nowalska-Kapuścik 2010: 171; Hryciuk, Korolczuk 2012; Titkow 2012). Kobiety uwalniają się od wzorca bezgranicznie poświęcającej się matki: „«Bycie dla dzieci» stało się przejściowym okresem w życiu kobiety, podczas gdy poprzednio służyło rodzeniu i wychowaniu społecznie oczekiwanej liczby dzieci" (Kwak 2005: 27). Z drugiej jednak strony, wspominana profesjonalizacja rodzicielstwa stawia przed matkami wiele wymagań, którym musi ona sprostać. Bogusława Budrowska, za Sharon Hays, mówi o „ideologii intensywnego macierzyństwa”, obejmującego ogrom czasu, energii i pieniędzy niezbędnych dla właściwej opieki i wychowania dziecka (Hays 1996: 97 i n., za: Budrowska 2000: 165). Biorąc pod uwagę, że rola matki łączona jest przez większość współczesnych kobiet z rolą pracownika i praca zawodowa stanowi dla nich wartość samą w sobie, wymaga to od kobiet świetnej organizacji czasu i pracy. Jednym słowem - bycia ,superwoman, czyli $3 \mathrm{w}$ 1: świetna pracownica, cudowna żona i wspaniała matka" (Budrowska 2000: 155). Kolejne wymagania stawiane przed kobietą dotyczą jej cielesności i fizycznej atrakcyjności. Elżbieta Korolczuk wskazuje na ideał ,useksualnionej matki” stojący w opozycji do opisywanej w tradycyjnym modelu macierzyństwa matki aseksualnej: „[...] matki nie mogą już pozostać «macierzyńskie», jeśli chodzi o ciało, czyli wygląd zewnętrzny i życie seksualne. Posiadanie potomstwa nie może już stanowić usprawiedliwienia dla gorszej formy fizycznej, najmniejszej choćby nadwagi czy braku orgazmu, nawet jeśli owe «grzechy» mają charakter tymczasowy" (Korolczuk 2012: 231). 
Z drugiej strony, zakwestionowanie instynktu macierzyńskiego i wrodzonego charakteru matczynej miłości i kompetencji prowadzi do „odczarowania” macierzyństwa. Przejawia się to $\mathrm{z} \mathrm{w}$ przyznaniu matkom „prawa do niedoskonałości”: prawa do odczuwania baby bluesa, depresji w czasie ciąży i depresji poporodowej, prawa do nieradzenia sobie z łączeniem obowiązków matki, żony i pracownika, „nawet prawa do nielubienia własnego dziecka” (Sikorska 2009a: 182; 2009b). Możliwość dzielenia się z innymi negatywnymi doświadczeniami macierzyństwa daje przede wszystkim Internet: blogi, fora internetowe oraz tzw. prasa zwierzeniowa (Dzwonkowska-Godula 2012; Stańczak-Wiślicz 2012).

Analiza nowoczesnego modelu kobiecości oraz macierzyństwa pokazuje, że do najistotniejszych zmian w stosunku do modelu tradycyjnego należą: brak nakazu macierzyństwa, podmiotowość w decydowaniu o sobie, w tym o własnej tożsamości, oraz zasada równości płci w różnych sferach życia społecznego (podkreślmy, że jest to ujęcie modelowe, idealne; trudnościom w jego urzeczywistnianiu poświęcony jest kolejny podrozdział). Obok możliwości (już nie konieczności) poświęcenia się rodzinie i spełnianiu się w roli matki, pojawia się możliwość łączenia ról rodzinnych i zawodowych (i traktowania ich jako równie ważnych) oraz możliwość rezygnacji z macierzyństwa na rzecz kariery zawodowej lub innych rodzajów aktywności.

Wydaje się, że większa rewolucja dokonała się w kulturowej definicji ojcostwa (i co z tym związane - męskości). Odrzucenie tradycyjnego wizerunku tej roli znajduje wyraz w języku. Mówi się zatem o „nowych” czy „nowoczesnych” ojcach, ojcach „,aktywnych”, „zaangażowanych”, podkreślając tym samym na zasadzie przeciwieństwa bierność i brak zaangażowania w rodzicielstwo tradycyjnych ojców (Piątek 2007; Budrowska 2008; Kubicki 2009; Sikorska 2009a; Grygiel 2010; Kluczyńska 2009; Williams 2008). Wprowadza się określenie „tacierzyństwo” zamiast „ojcostwo”, by podkreślić ich odmienność i zwrócić uwagę na „nową jakość” ojcostwa (Monkiewicz-Święcicka 2005; Budrowska 2008: 3). Paweł Kubicki zwraca uwagę, że także w języku angielskim odróżnia się pojęcie fatherhood, oznaczające „ojcostwo" i odnoszące się do „pełnienia odpowiedniej roli społecznej”, od pojęcia fathering mówiącego o „byciu ojcem” nie w znaczeniu roli, lecz działania, ,tworzenia i budowania ojcostwa poprzez kontakt z dzieckiem” (2009: 102). Jak stwierdza Bogusława Budrowska, „pojęcie «tacierzyństwo» bliższe jest pojęciu «macierzyństwo» niż pojęciu «ojcostwo» nie tylko ze względu na budowę słowa, również w warstwie znaczeniowej za terminem tym kryje się bardziej zbliżony do kobiecego, niż tradycyjne męskiego, sposób pełnienia roli rodzica" (Budrowska 2008: 3). Także w odniesieniu do uprawnień przysługujących pracującym mężczyznom posiadającym małe dzieci stosuje się określenie „urlop tacierzyński”, rzadziej ,urlop ojcowski”. Dowodzi się możliwości stworzenia relacji mężczyzny z dzieckiem porównywalnej z relacją matczyną: ,$[\ldots] \mathrm{w}$ połowie lat $70 . \mathrm{XX}$ w. zauważono [...], że noworodek próbuje nawiązać więź z każdym dorosłym, którego widzi, niezależnie czy to jest kobieta czy 
mężczyzna, i że jakość kontaktów dziecko - ojciec jest właściwie taka sama, jak jakość kontaktów dziecka z matką. Dlatego ojciec może być bez większych przeszkód zastępczym opiekunem, czy też - jak się jeszcze wtedy wyrażano - substytutem matki” (Szlendak 2009: 65). Ponadto, „zrównuje” się kobiety i mężczyzn jeżeli chodzi o posiadanie przez nich „rodzicielskich kompetencji”, rezygnując z pojęcia instynktu macierzyńskiego jako określającego „wrodzoną” i właściwą tylko kobietom wiedzę o pielęgnacji i wychowaniu dziecka, bądź też wprowadzając pojęcie ,instynktu ojcowskiego" i tym samym przypisując mężczyznom „naturalne” predyspozycje do opieki nad potomstwem. W jednym z badań ojcowie wyrazili przekonanie o istnieniu takiego instynktu u mężczyzn, stwierdzając u siebie „pokłady miłości, opiekuńczości i czułości” wyzwalane w kontaktach z małymi dziećmi (Chmura-Rutkowska, Ostrouch 2007: 260).

„Nowe ojcostwo" nie ogranicza się do zapewniania środków materialnych rodzinie, ale opiera się na silnej i głębokiej więzi emocjonalnej ojca z dzieckiem oraz zaangażowaniu mężczyzny w opiekę i wychowanie potomstwa (Pleck 1987: 93; Budrowska 2008; Kubicki 2009: 87; Sikorska 2009a: 192). Rygor i surowość ojca zastępuje traktowanie dziecka jak partnera, karanie jest zastępowane pomaganiem itp. (Arcimowicz 2003). „Nowoczesny ojciec [...] znacznie lepiej niż «tradycyjny ojciec» zdaje sobie sprawę z potrzeb emocjonalnych dziecka i potrafi je aktywnie i troskliwie wychowywać" (Matuszewska 2003: 33, za: Gębuś 2006: 58). Badacze mówią o „męskości opiekuńczej” (caring masculinity), nastawionej na współpracę, troskę o innych i pozytywne relacje międzyludzkie (Holter 2003, za: Kwiatkowska, Nowakowska 2006: 17, 31). Zdaniem E. Badinter, nowi ojcowie mogą pojawić się dopiero, „gdy mężczyzna zakwestionuje odziedziczoną po przodkach represyjną ideę męskości, dostrzeże całą niewygodę patriarchatu, zrozumie krzywdę odsunięcia od własnych dzieci wskutek odrywającego go od domu typu pracy, zaakceptuje swoją kobiecość i wreszcie rozpocznie poszukiwanie innej męskości i innego ojcostwa" (Badinter 1993).

„Nowy” mężczyzna jest zaangażowany w rodzicielstwo od momentu dowiedzenia się, że zostanie ojcem - „Jeśli mężczyzna chce być ojcem w sposób aktywny i świadomy, to okres ciąży jest czasem nowych doświadczeń i przeżyć, intensywnych uczuć i uczenia się nowych ważnych rzeczy" (Bullinger 1997: 14; 43). Podczas gdy w tradycyjnym modelu płci ciąża i poród były wyłącznie „sprawą" kobiety, w modelu nowoczesnym oboje partnerzy "są w ciąży” i przeżywają poród - pojawiają się tu określenia „ojciec rodzący”, „ojciec rodziciel” (Piątek 2007: 100; Gębka 2007). „Nowi” ojcowie swoje uczestnictwo w narodzinach dziecka traktują jako obowiązek i warunek zbudowania więzi z dzieckiem (Bullinger 1997: 14). Jak zauważa Mikołaj Gębka, rodzinne porody były czymś naturalnym, kiedy narodziny dziecka obywały się w domu, a nie w szpitalu (Gębka 2007: 90, 93). Jednak nie miały one wiele wspólnego ze współczesnymi wspólnymi porodami, gdyż mężczyźni jedynie przebywali w pobliżu rodzących żon, a nie brali udziału bezpośrednio w samym akcie narodzin. Od blisko trzydziestu lat w Polsce 
szpitalne porodówki umożliwiają ojcom obecność przy przyjściu dziecka na świat i coraz więcej mężczyzn z tej możliwości korzysta (pierwszy poród rodzinny miał miejsce w Łodzi w 1983 roku) (Fijałkowski 1996, za: Gębka 2007: 94).

Dla „,nowych” ojców oczywiste jest uczestniczenie od początku w opiece nad noworodkiem, uczenie się razem z matką czynności pielęgnacyjnych, poznawanie dziecka (Bullinger 1997: 14). Potrafią być oni przy tym równie opiekuńczy, troskliwi i czuli jak kobiety, pod warunkiem jednak, że poddadzą się swej wewnętrznej kobiecości i „uśpią swą tradycyjną męskość”. „Liczne badania stosunku ojciec - osesek dotyczące pierwszych sześciu miesięcy, stwierdzają kategorycznie, że ojcowie matkują równie dobrze jak same matki” (Badinter 1993: 154). E. Badinter zwraca uwagę na językową pułapkę tkwiącą w pojęciu „matkowania", wskazującym, kto ma zajmować się dzieckiem (tamże). Autorka podkreśla, że „«matkowanie» nie ma płci”, a w związku z odchodzeniem od specjalizacji ról rodzicielskich lepiej stosować pojęcia „neutralne płciowo" i zacierające rozróżnienie płciowe jak w języku angielskim pojęcie nurturing, oznaczające, „żywienie fizyczne i uczuciowe", czy parenting - rodzicielstwo (tamże).

Przemianie roli ojca towarzyszą refleksje na temat znaczenia męskiego rodzica w życiu dzieci i ich prawidłowym rozwoju, zarówno chłopców, jak i dziewczynek (Biddulph 2004: 82; Flood 2003: ix). Pokazuje się konsekwencje zjawiska „nieobecnych ojców” (Badinter 1993: 153; Bullinger 1997: 192-196; Arcimowicz 1998: 4; Groth 2000; Biddulph 2004: 105; Gębka 2006: 128; Budrowska 2008: 125-126). Z drugiej strony, podkreśla się znaczenie bycia rodzicem w życiu mężczyzny, przede wszystkim dla jego psychicznego i emocjonalnego rozwoju (Pospiszyl 2004: 24, Biddulph 2004: 28; Skowrońska 2008: 200). „W każdym przypadku posiadanie dziecka stwarza ojcu możliwość osiągnięcia wyższego etapu rozwoju społecznego. Ze względu na specyficzność powiązań emocjonalnych sytuacja ta [...] nie może być zastąpiona przez żadną inną" (Pospiszyl 2004: 24). Wskazuje się także, że zaangażowanie mężczyzny w życie rodzinne pozytywnie wpływa na jego samopoczucie i zadowolenie z życia, które w tradycyjnym modelu męskości wiązane było przede wszystkim z pracą zawodową (Szlendak 2010: 449).

Tradycyjna specjalizacja ról rodzicielskich sprawiła, że współcześni mężczyźni potrzebują specjalnych warsztatów dla ojców, które mają uczynić z nich zaangażowanych, aktywnych rodziców, wprowadzić ich w tajniki rodzicielstwa i pomóc im „odkryć w sobie supertatę” (http://www.tato.net, 29.09.2015). Konieczność „szkolenia” mężczyzn uzasadnia się brakiem pozytywnych wzorców ojca w rodzinnym domu (Biddulph 2004: 82, 83; Chmura-Rutkowska, Ostrouch 2007: 260). Jak stwierdzają twórcy portalu Tato.net: „Jesteśmy pierwszym pokoleniem mężczyzn, którzy zdają sobie sprawę z tego, jak bardzo potrzebujemy wzajemnego wsparcia i współpracy, aby skutecznie spełniać swoją rolę" (Tato.net 2005). Organizowane są kampanie społeczne, funkcjonują serwisy internetowe poświęcone ojcostwu, mężczyźni prowadzą blogi, publikują książki, w których dzielą się swoimi rodzicielskimi doświadczeniami i przemyśleniami (Kubicki 
2009; Budrowska 2008). Powstają także organizacje skupiające samotnych ojców, których dzieci po rozwodzie zostały przy matkach (Stowarzyszenia Obrony Praw Ojców; http://wstroneojca.pl, 29.09.2015).

Podsumowując rozważania na temat nowoczesnego macierzyństwa i ojcostwa, warto odwołać się do teorii matriarchatu Johanna J. Bachofena, który analizował zmieniające się znaczenie roli matki i ojca w procesie ewolucji społecznej (Fromm 1999: 16). Zwieńczeniem społecznego rozwoju jest, według Bachofena, odrzucenie patriarchalnego porządku i osiągnięcie społecznej harmonii równowagi poprzez połączenie tego co tradycyjnie męskie, z tym co kobiece, tego co przypisane macierzyństwu, z tym co jest traktowane jako właściwość ojcostwa. Jak przedstawia to Erich Fromm: ,[...] tok dziejów wiedzie od przedracjonalnego świata macierzyńskiego do racjonalnego świata ojcowskiego, a zarazem od wolności i równości do hierarchii i nierówności. Na koniec człowiek ma powrócić do stanu miłości i równości, osiągając je na nowym poziomie, który będzie połączeniem zasad matriarchalnej i patriarchalnej" (Fromm 1999: 16). Do koncepcji tej nawiązuje Ole Vedfelt, stwierdzając, iż najlepszym środowiskiem życia dla jednostek jest kultura, która nie jest ,ani matriarchalna, ani patriarchalna, lecz ludzka - męskość i kobiecość będą mogły być w niej używane świadomie jako współgrające ze sobą siły dynamiczne" (Vedfelt 2004: 235). Można stwierdzić, że w nowoczesnym modelu płci chodzi z jednej strony właśnie o zrównoważenie znaczenia kobiecości i męskości, macierzyństwa i ojcostwa. Z drugiej zaś strony - o umożliwienie jednostce bycie sobą bez względu na płeć, to znaczy, brak konieczności bycia „kobiecą kobietą” i „męskim mężczyzną”, troskliwą mamusią i surowym ojcem.

\subsection{Spory wokół nowoczesnego modelu płci kulturowej oraz macierzyństwa i ojcostwa}

Przedstawiony nowoczesny model kobiecości i męskości, macierzyństwa i ojcostwa jako typ idealny nie występuje w czystej postaci w rzeczywistości społecznej (podobnie jak model tradycyjny). Ponieważ kulturowa zmiana modeli dopiero powoli, stopniowo się dokonuje, mamy do czynienia z trwaniem starego porządku (lub jego elementów) oraz przejawami nowego sposobu postrzegania kobiet i mężczyzn oraz relacji między płciami. Jedną z przyczyn trudności w upowszechnieniu się nowoczesnego modelu płci może być fakt, że jest on niejednoznaczny i budzi wiele wątpliwości. Problem stanowi odpowiedź na pytanie, do czego ma prowadzić odrzucenie tradycyjnego modelu - czy do unifikacji cech i ról płciowych („,bezpłciowy” świat w sensie utraty znaczenia bycia kobietą/mężczyzną dla funkcjonowania jednostki), czy też braku narzucania jakichkolwiek schematów i przyznania równego prawa dla różnych sposobów bycia sobą (świat wielu kobiecości i męskości i innych form płciowości). 
Pytanie, czym miałoby być odrzucenie patriarchalnego porządku i związanych z nim tradycyjnych definicji kobiecości i męskości można, za Ewą Malinowską, sprowadzić do odwiecznego i nierozstrzygniętego dylematu: równość czy różnice płci (Malinowska 2000: 21-27). Autorka przypomina m.in. oświeceniową koncepcję równości płci, według której ,wszelkie różnice w zachowaniach kobiet i mężczyzn są rezultatem procesu socjalizacji, a więc mają charakter różnic kulturowych” oraz przekonanie romantyków o naturalnych, ,,wrodzonych” różnicach płci, uwarunkowanych biologicznie i uzasadniających konieczność istnienia społecznych nierówności płci (tamże: 22-23). Obie te koncepcje miały swoich kontynuatorów w ramach ruchu feministycznego drugiej fali ${ }^{6}$, w którym można wyodrębnić dwa główne nurty: feminizm równości oraz feminizm różnicy, określane przez Macieja Ulińskiego jako „dwa bieguny strategii antypatriarchalnej” (Malinowska 2000: 27; Uliński 2001: 311; Pakszys 2009: 250). Pierwszy opiera się na założeniu o braku istotnych różnic między kobietami i mężczyznami i nawiązuje do androgynicznej koncepcji natury ludzkiej (Uliński 2001: 305; Malinowska 2000: 60, 61). Takie podejście propagowane było m.in. przez Simone de Beauvoir w książce Druga płeć, która wywołała gorącą dyskusję i spotkała się z zarzutami „zdrady kobiecości” (Uliński 2001: 290-291). Pojawiły się głosy, że propagowanie uniwersalnego, „bezpłciowego" ideału człowieczeństwa jest w gruncie rzeczy propagowaniem „męskiego" ideału oraz utrwalaniem androcentryzmu i prowadzi tym samym do maskulinizacji społeczeństwa. Według Moniki Bobako, takie rozumienie równości płci przypomina projekt asymilacji mniejszości kulturowych, które płacą wysoką cenę „,utraty siebie” za podwyższenie statusu społecznego, a i tak czują się obco i nie na miejscu, wchodząc w role innego (Bobako 2010: 238-239). Odpowiedzią na pytanie, jak nie zatracić różnicy płci i kobiecej unikalności i jednocześnie dążyć do wyrównania statusu kobiet i mężczyzn, był feminizm różnicy. Jego przedstawicielki uznawały istnienie różnic płciowych i podkreślały odrębność kobiet, ich doświadczeń, cech, dyspozycji i potrzeb, domagając się społecznego uznania kobiecej inności i traktowania kobiecych wartości na równi z męskimi (Malinowska 2000: 66-67; Dybel 2006: 44; Bobako 2010: 303). Jak zauważa Ewa Malinowska, wymagało to zakwestionowania $z$ jednej strony patriarchalnego porządku i androcentryzmu, $z$ drugiej strony - feminizmu równości, ,który w imię równouprawnienia deprecjonuje kobiecość i kobiece wartości, zmusza kobietę do wyparcia się tożsamości płci, lansuje model aseksualnego podmiotu" (Malinowska 2000: 67). Odrzucono tym samym

${ }^{6}$ Badacze zwracają uwagę, że pojawienie się dwóch orientacji w ujmowaniu kobiecości i męskości miało miejsce już w pierwszej fali feminizmu (Gordon 1991, za: Umińska, Mikos 1993: 5). Monika Bobako wyróżnia, za Karen Offen, „feminizm indywidualistyczny”, podkreślający uniwersalne cechy łączące kobiety z mężczyznami, kładący nacisk na prawa człowieka, oraz „feminizm relacyjny" domagający się równości płci, akcentujący różnicę między kobietami i mężczyznami oraz specyfikę kobiecych zadań w rodzinie i narodzie (Offen 2000, za: Bobako 2010: 225). 
rozumienie „równości jako toż-samości”, domagając się „takiego przedefiniowania równości, które nie ignorowałoby różnicy, które nie przeciwstawiałoby się jej, nie wymagało zniwelowania” (Bobako 2010: 220). „Chodzi o to, aby kobieta będąc równa mężczyźnie zachowała zarazem swoją odmienność w stosunku do niego" (Dybel 2006: 44). W skrajnej wersji feminizm różnicy prowadzi do kobietocentryzmu, wywyższając cechy kobiece jako ważniejsze społecznie i wyższe od męskich, co tym samym zaprzecza zasadzie „różni, ale równi” (Malinowska 2000: 67; Umińska, Mikos 1993: 6). Wciąż bez odpowiedzi jednak pozostaje pytanie, jak osiągnąć „równość w różności”? (Dybel 2006: 44; Putnam Tong 2002: 45). Ponadto, co zauważa Elżbieta Pakszys, należy rozważyć, czy domaganie się równości poprzez podkreślanie różnic płciowych nie stoi w sprzeczności z ideą humanizmu, głoszącego ,jedność gatunku ludzkiego” (Pakszys 2009). Zdaniem autorki, wobec wzrostu pluralizmu i relatywizmu we współczesnym społeczeństwie oraz postmodernistycznego odrzucenia ,jednej arbitralnej uniwersalnej (ponad)ludzkiej natury i prawdy" konieczna stała się redefinicja humanizmu (tamże: 252-253). Co więcej, postępująca „partykularyzacja wszelkich uniwersalizmów" wymaga zaprzestania mówienia nie tylko o człowieku, ale także o kobiecości i męskości „,w ogóle” i uwzględniania zróżnicowania w ramach kategorii kobiet oraz mężczyzn (chociażby ze względu na wiek, rasę, pochodzenie społeczne, wyznanie, orientację seksualną itp.) (tamże: 252, 255). Stąd też na przykład rozróżnienie na „,biały” i „,czarny” feminizm, feminizm chrześcijański, feminizm lesbijski itd. (Humm 1993; Mizielińska 2008). Monika Bobako określa współczesne kontynuacje feminizmu różnicy mianem „polityki różnicy”, rozumianej szeroko jako „polityka sprzeciwu wobec wykluczającej polityki toż-samości” (Bobako 2010: 220-221).

Elżbieta Pakszys, analizująca poszukiwania optymalnych strategii wobec zróżnicowania płci, wyodrębniła trzy warianty (Pakszys 2000: 56). Po pierwsze, maksymalizowanie kontrastu $\mathrm{w}$ dychotomii płci, z którym mamy do czynienia w tradycyjnym modelu płci i który obecnie zostaje zakwestionowany. Po drugie, minimalizowanie różnorodności, czyli strategia „unisex” (takie ujęcie pojawia się w ramach feminizmu równości). Po trzecie wreszcie, ,pełny liberalizm w tej mierze, który polegałby na swobodzie ekspresji płci/rodzaju, dopuszczającej powstawanie wielu modeli męskości i kobiecości (w tym również strategii androginii i ginoandrii)" (tamże). Nowoczesnemu modelowi kobiecości i męskości odpowiadałby ostatni wariant, czyli pełny liberalizm w realizacji swojej płci, uprawomocniający społeczną różnorodność w tym zakresie i niewartościujący żadnej z form bycia kobietą/mężczyzną. Także Ewa Malinowska wskazuje na możliwą „trzecią drogę" w postrzeganiu relacji między płciami, zaproponowaną przez feministki różnicy. Autorka podkreśla, że odejście od patriarchalnego porządku społecznego (,wojna płci”) nie musi oznaczać „,androgynii kulturowej” (Malinowska 2009: 45). Społeczeństwo może być oparte „na równouprawnieniu wartości kobiecych i męskich przy pełnej akceptacji różnic między płciami” (tamże). 
Badacze podkreślają, że zróżnicowanie płci kulturowej służy rozwojowi społeczeństwa, może bowiem „prowadzić do zwiększania bogactwa kulturowego, dającego się także ocenić jako zwiększona możliwość adaptacyjna (w sensie ewolucyjnym)" (Pakszys 2000: 56) ${ }^{7}$. Wydaje się jednak, że chodzi tu przede wszystkim o „egzystencjalny komfort” jednostek i umożliwienie im życia odpowiadającego ich predyspozycjom, zdolnościom, zainteresowaniom itp., gdy tradycyjne schematy płciowe nie pozostawiają im wyboru i wolności w „byciu sobą”. Na problem ten wskazywała Margaret Mead, głosząc „wyższość kultur wielowymiarowych, umożliwiających większości jednostek wybór zróżnicowanych w swym charakterze dróg życiowych nad kulturami jednowymiarowymi, w których droga życiowa jednostki jest społecznie zdeterminowana od narodzin po śmieré" (Uliński 2001: 295). Badaczka wiele miejsca w swej pracy prezentującej trzy różne kultury badanych plemion poświęciła dewiantom, osobom odbiegającym w swych zachowaniach od ideałów i norm obowiązujących w danej społeczności (Mead 1986). Wyniki jej badań pokazały, że każde społeczeństwo oczekujące od swoich członków realizacji określonego wzoru osobowego - czy identycznego dla wszystkich bez względu na płeć, czy innego dla kobiet i mężczyzn - musi zmierzyć się z problemem nieprzystosowania pewnej grupy jednostek, które, z jakichś przyczyn, w tych narzuconych schematach się nie mieszczą. Margaret Mead wyrażała nadzieję, że „w dostatecznie bogatych we wzory życia kulturach będzie można znacznie ograniczyć represywność związaną z przypisywaniem każdej płci odmiennego typu charakteru, ról, wyglądu itp." (Uliński 2001: 298, 299).

Wiele nieporozumień w związku z nowoczesnym modelem płci wywołuje koncepcja androgyniczności (Badinter 1993: 145). Skoro „,androgyne”, zgodnie z grecką etymologią (anér-andros - mężczyzna i gyné-gynaicos - kobieta) jest połączeniem kobiecości i męskości, dla niektórych oznaczało to kumulację, nakładanie się na siebie obu pierwiastków, prowadzące do zniewieścienia mężczyzn i maskulinizacji kobiet, a zatem do upodobnienia się obu płci (tamże: 145, 146). Inni z kolei traktowali to jako rozmycie się płciowości jednostki, brak jakichkolwiek cech płciowych, „rodzaj nijaki” (tamże). E. Badinter podkreśla, że oba te stanowiska należą raczej do przeszłości. „Człowiek-androgyne nie należy do «płci płynnej, niepewnej» [...] Nie jest także jednocześnie żeński i męski. Zależnie od wymogu chwili na zmianę wyraża swoje składniki. [...] Tożsamość androginiczna pozwala na przypływy i odpływy w eksponowaniu cech kobiecych i męskich. [...] przypomina grę dwóch uzupełniających się elementów, których intensywność zmienia się zależnie od osoby" (tamże: 148). Tak rozumiana androgyniczność w nowoczesnym społeczeństwie ,jest w cenie" i czyni życie człowieka łatwiejszym ze względu na jego większą elastyczność. Pojawiły się zatem

7 Jak zauważa Elżbieta Pakszys na możliwość tę wskazują niezależnie od siebie badacze reprezentujący „opcję naturalistyczną”, jak Edward O. Wilson, oraz „opcję kulturalistyczną”, jak Margaret Mead (Pakszys 2000: 56). 
koncepcje postulujące, by w procesie socjalizacji nie narzucać dzieciom „schematów płciowych" (socjalizacja neutralna pod względem płci - gender-neutral socialization) (Beauvoir 1972: 26-26, za: Uliński 2001: 290; Badinter 1993: 148; Martin 2005). Betty Friedan w książce The Fountain of Age postulowała „wychowywanie chłopców i dziewczynek w duchu androgynii, tak aby łączyli w sobie zarówno cechy kobiece, jak i męskie" (za: Dybel 2006: 45). Zdaniem Pawła Dybla, „[...] ujęcie to implikuje wyprodukowanie nowego pokolenia ludzkości, w którym zaniknęłyby wszelkie różnice między płciami: przestałby więc istnieć problem «różnicy seksualnej». Kobiecość i męskość uległaby samozniesieniu w jednym, androgynicznym osobowościowym tworze, chłopco-dziewczynce czy dziewczynko-chłopcu, który miałby być «twórczą» syntezą obu płci” (Dybel 2006: 45). Propozycję B. Friedan oraz innych autorów można jednak (i chyba powinno się) odczytać nie jako próbę „wyhodowania nowego typu człowieka”, łączącego w sobie „pozytywne” cechy kobiece i męskie, ale jako postulat umożliwienia każdej jednostce rozwinięcia swojej płciowości bez narzucania schematów, czym jako kobieta i mężczyzna powinni się charakteryzować, jakie predyspozycje, zainteresowania itd., przejawiać.

Sandra L. Bem, która swoim Inwentarzem do Badania Płci Psychologicznej zapoczątkowała niejako „karierę” pojęcia androgynii w psychologii, zwraca uwagę, że pojęcie to spotkało się z krytyką ze strony feministek. Ich zdaniem koncepcja androgyniczności w istocie podtrzymuje polaryzację płci, którą miała zakwestionować (Bem 2000: 121-122). Skupia się bowiem na zjawisku łączenia przez jednostkę kobiecości i męskości, a ignoruje problem ich kulturowych podstaw, przyjmując niejako, że kobiecość i męskość są ,pojęciami danymi, a nawet ustalonymi strukturami osobowości” (tamże). Za pytaniem: ,jacy jesteśmy?” (w jakim stopniu kobiecy i męscy), nie idzie pytanie: „dlaczego jesteśmy właśnie tacy?”. Sama autorka, rozwijając teorię „schematyzmu rodzajowego", kładzie nacisk na kulturowy wymiar płci i określa osoby typowo płciowe (wg wyniku osiągniętego w Inwentarzu do Badania Płci Psychologicznej) jako ludzi „głęboko przesiąkniętych kulturową definicją rodzaju" (Bem 2000: 123). Sandra Bem podkreśla, że nie należy interpretować koncepcji androgynii (a także jej teorii schematyzmu rodzajowego) jako postulatu doszukiwania się w sobie męskich i żeńskich pierwiastków przez jednostki. Jej przesłaniem jest pokazanie, że „W obecnym kontekście historycznym stworzona przez kulturę dychotomia męskie-żeńskie nie musi i nie powinna być powielana ani przez kulturę, ani w osobowości jednostek" (tamże: 124). Jednak zdaniem badaczki nie jest możliwe zupełne odrzucenie schematycznego postrzegania płci (Bem 2000: 181).

${ }^{8}$ Schematyzm rodzajowy autorka rozumie jako odwoływanie się do polaryzacji rodzajowej w postrzeganiu i klasyfikowaniu rzeczywistości społecznej przez jednostki, które przyswoiły ten schemat w procesie socjalizacji i nie potrafią się od niego uwolnić (Bem 2000: 122). 
Badacze wskazują na trwałość stereotypów płci i utrzymujące się nierówności płci w różnych wymiarach życia społecznego. Zdaniem Tomasza Szlendaka zmiana patriarchalnego społeczeństwa ma charakter powierzchowny, to jedynie „kosmetyczna przemiana patriarchatu” (Szlendak 2009). Jak stwierdza Ewa Hyży: „Chociaż mężczyznom wolno teraz płakać w trakcie programów telewizyjnych, to zinstytucjonalizowane relacje władzy pomiędzy kobietami a mężczyznami nie zanikły” (Hyży 2010: 84). Według Todda Nelsona, ,seksizm wcale nie osłabł - gwałtownie zmalała jedynie gotowość do ujawniania seksistowskich przekonań" (Nelson 2003: 288). Autorzy wyróżniają „,seksizm tradycyjny” oraz „seksizm współczesny” (Swim i in. 1995: 199, za: Nelson 2003: 288). Pierwsza z postaw obejmuje przekonanie o naturalnym podziale cech i ról płci, wartościowanie tego co męskie oraz uprzedzenia wobec kobiet. Druga postawa natomiast przejawia się w zaprzeczaniu istnienia dyskryminacji płci oraz co za tym idzie, odrzucaniu rozwiązań na rzecz równouprawnienia oraz poprawy sytuacji kobiet jako nieuzasadnionych i niepotrzebnych. W literaturze przedmiotu opisywane jest także zjawisko „neoseksizmu”, będącego „przejawem konfliktu między egalitarnymi wartościami a utrzymującymi się negatywnymi uczuciami do kobiet" (Tougas i in. 1995: 843, za: Nelson 2003: 290). Badacze zauważają, że wyeliminowanie stereotypów i uprzedzeń opartych na płci jest bardzo trudne, jeśli nie niemożliwe, bo wiele osób nie rozpoznaje seksizmu, nawet bezpośrednio się z nim stykając (Nelson 2003: 303).

Nowe wizerunki kobiecości i męskości spotykają się z krytyką i odrzuceniem, na przykład mężczyzna metroseksualny uznawany jest w niektórych kręgach za „lalusia”, homoseksualistę, niemęskiego, zniewieściałego mężczyznę (Barabasz 2007: 148). Jeśli kobieta deklaruje, że nie chce mieć dziecka i „nie czuje" instynktu macierzyńskiego, może spotykać się z zarzutami, że nie jest „prawdziwą” kobietą, a gdy nie podkreśla swojej płci za pomocą stroju, fryzury, makijażu, ubierając się „po męsku” otrzymuje etykietkę „babochłopa”. Badacze wskazują na przejawy oporu przeciwko zmianie kulturowego modelu i wzoru płci i próby utrzymania, czy powrotu do tradycyjnego sposobu realizowania kobiecości i męskości. Ta „kontrofensywa czy kontratak (backlash) ze strony organizujących się sił i stanowisk patriarchalnych i neokonserwatywnych" przejawia się m.in. w mówieniu o kryzysie męskości i ojcostwa (zamiast o redefinicji czy zmianie modelu męskości), oraz wskazywanie ich negatywnych skutków dla całego społeczeństwa - nie tylko dla mężczyzn, ale także kobiet i dzieci, pozbawionych wzorca „prawdziwego mężczyzny” (Pakszys 2009: 254; Arcimowicz 2010: 14; Piątek 2007: 94). Pojawiają się ruchy mężczyzn opowiadających się za specjalizacją ról płciowych, przywróceniem uprzywilejowanych pozycji mężczyzny, w tym „,autorytetu ojca w rodzinie”, oraz „odzyskaniem” męskiej tożsamości - „utraconej prawdziwej męskości" (Pospiszyl 1998: 17; Arcimowicz 2003: 35; 2010: 14; Kimmel, Kaufman 2003; Kluczyńska 2009: 116; Hyży 2010; Wojnicka 2010). Ewa Hyży określa je mianem „hegemonicznych” - są to ruchy konserwatywne, 
broniące Connellowskiej hegemonicznej, tradycyjnej męskości, wyróżniając także ruchy „kontrhegemoniczne”, opowiadające się za zmianą patriarchalnego

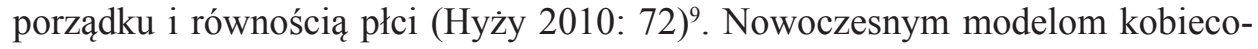
ści i męskości nie sprzyjają treści propagowane przez środki masowego przekazu oraz szkolne podręczniki (m.in. Wóycicka, Dominiczak 2000; Twardowska, Olczyk 2000; Klimczak-Ziółek 2005, 2006; Arcimowicz 2003; Kowalczyk i in. 2007; 2009; Środa, Rutkowska 2007; Dzierzgowska 2009). Tradycyjny model płci jest utrwalany i propagowany na przykład w popularnych książkach, takich jak Mężczyźni sa z Marsa a kobiety z Wenus Johna Greya (1995) czy wspominana Pteć mózgu Anne Moir i Davida Jessela (1993), w których podtrzymuje się przekonanie o naturalnej odmienności kobiet i mężczyzn (Arcimowicz 2003: 37, 38). Chociaż w mediach w ostatnim czasie coraz częściej pojawiają się reklamy przełamujące tradycyjny wizerunek kobiet i mężczyzn - występuje w nich ojciec - czuły opiekun dziecka i kobieta w pracy zawodowej, także na wysokim stanowisku, to nadal typowym reklamowym obrazkiem pozostaje ten, w którym kobieta - otoczona dziećmi matka, żona i gospodyni domowa czeka z obiadem na wracającego z pracy męża. Zdecydowanie uboższe, jeżeli chodzi o różnorodność wzorów kobiecości i męskości, są podręczniki szkolne odwołujące się do polaryzacji płci i specjalizacji ról kobiecych i męskich zgodnie z tradycyjnym modelem. Treść podręczników jest pod tym względem „odporna” na zmiany, mimo że zgodnie z Konwencją o Eliminacji Wszelkich Form Dyskryminacji Kobiet (ratyfikowaną przez Polskę w roku 1981) nie powinno być w nich miejsca dla powielania stereotypów kobiecości i męskości (Wóycicka, Dominiczak 2000; Środa, Rutkowska 2007).

Zdaniem Ulricha Becka, zmiany w definiowaniu płci i relacji między płciami zaszły „w świadomości i na papierze”, ale nie w zachowaniach i położeniu mężczyzn i kobiet, co wyraźnie widoczne jest na przykład na rynku pracy (Beck 2002: 152). Za „,retoryka równości” nie idą czyny (tamże). „Znajdujemy się [...] dopiero na początku wyzwalania się ze «stanowych» ról przypisanych przez płeć. Świadomość wyprzedziła rzeczywistość" (tamże). Utrzymujące się nierówności płci są coraz bardziej uświadomione i mniej uprawomocnione, co według autora prowadzi do długiego konfliktu płci. Podobną opinię na temat szans urealnienia nowoczesnego modelu płci znajdujemy u A. Giddensa, stwierdzającego: „możliwość i rzeczywistość to dwie zupełnie różne sprawy” (Giddens 2009: 144). Według Przemysława Gębali, „[...] ponowoczesność jako źródło nowych

${ }^{9}$ Katarzyna Wojnicka proponuje inną typologię ruchów mężczyzn: ruchy działające przede wszystkim w szeroko pojmowanym interesie mężczyzn jako odrębnej kategorii społecznej, jak ruch obrony praw ojców, obrony praw mężczyzn, mitopoetycki i męskie ruchy parareligijne określa mianem „maskulinistycznych”, podkreślając istnienie także męskich ruchów profeministycznych, uwzględniających interesy kobiet, czy też szerzej: obu płci (2010). 
wzorów kulturowych wydaje się ograniczona do dyskursu naukowego i praktyk grup mniejszościowych. Schematy płci przejawiające się w stereotypach wciąż dominują w życiu społecznym, a tolerancja różnorodności, szczególnie w ramach zachowań związanych z seksualnością, stanowi nadal przejaw awangardy myślenia" (Gębala 2007: 24).

Ulrich Beck wskazuje na przyczynę trudności w realizacji nowoczesnego modelu płci (inaczej mówiąc: powstania nowoczesnych wzorów płci) - jego zdaniem tradycyjny podział ról na kobiece - męskie i związany z nim nierówny status płci stanowi podstawę przemysłowego społeczeństwa, a zatem społeczna zmiana musiałaby obejmować dogłębne zmiany jego instytucjonalnej struktury (Beck 2002: 163, 169-170, 188). Stwierdza on: „Równouprawnienia mężczyzn i kobiet nie można zrealizować w strukturach instytucjonalnych, które zakładaja ich nierówność. Nie można «okrągłych» ludzi wtłaczać w stare «kanciaste» pudła kryteriów rynku pracy, systemu zatrudnienia, urbanistyki, systemów zabezpieczeń społecznych itd." (tamże: 169-170). Autor dostrzega trzy scenariusze przyszłego rozwoju i poradzenia sobie ze sprzecznościami, jakie wiążą się ze ścieraniem się tradycyjnego i nowoczesnego modelu płci. Pierwszy wariant to powrót do tradycyjnego podziału ról (,konserwowanie rodziny”), niemożliwy do realizacji, bo przecież nie da się „,cofnąć zegarów modernizacji” (tamże: 182-185). Druga możliwość, to zrównanie statusów kobiet i mężczyzn we wszystkich sferach życia społecznego, przede wszystkim w sferze zawodowej (,generalizacja rynku pracy”), co jednak, jego zdaniem, doprowadziłoby do powstania społeczeństwa samotnych kobiet i mężczyzn (tamże 185-187). Autor uzasadnia taką prognozę, wskazując sprzeczność między rodziną a rynkiem pracy (którego organizacja nie zmienia się): wymogi dyspozycyjności i mobilności wobec pracowników uniemożliwiają wypełnianie obowiązków rodzinnych, a jeśli kobiety nie będą godzić się na rezygnację z aktywności zawodowej na rzecz rodziny, upowszechni się życie w pojedynkę (tamże). „Owa forma egzystencji jest prawdopodobnie niedostrzegana i niechciana konsekwencja żadania równości ptci w danych warunkach instytucjonalnych [podkr. K.D.-G.]. [...] Nierówności między kobietami i mężczyznami nie mają charakteru powierzchniowego i nie mogą być korygowane w strukturach i formach rodziny oraz w sferze zawodowej" (Beck 2002: 187-188). Zdaniem Ulricha Becka jedynym rozwiązaniem, choć utopijnym w jego ocenie, jest odejście od ról kobiety i mężczyzny i stworzenie, ,instytucjonalnych możliwości ponownego połaczenia pracy $i \dot{z} y c i a ”$, które nie stawiałyby jednostek przed koniecznością wyboru „rodzina albo praca" (tamże: 188). To wymagałoby z jednej strony zmiany w obszarze rynku pracy, na przykład wypracowanie „partnerskich form mobilności” lub „uznanie niemobilności ze względów rodzinnych”, czy „osłabienie związku między zapewnieniem bytu i aktywnością zawodową" (tamże: 188-189). $\mathrm{Z}$ drugiej strony, konieczne byłoby stworzenie „nowych możliwości społecznego współżycia ludzi”, które ułatwiłyby na przykład pełnienie ról rodzicielskich 
przez wsparcie ze strony innych rodzin, sąsiedztwa, szkoły, czy specjalnych usług opiekuńczych (tamże: 189-190). Autor pokazuje, że zmiana powinna się zacząć i zaczyna właśnie w sferze prywatnej - „Nowe formy wspólnego życia poza stanowym przypisaniem muszą znaleźć i wypracować sami mężczyźni i kobiety. [...] Gdzie nie spojrzeć, dostrzegamy ciężką pracę, jaka wykonywana jest na co dzień w ramach relacji i związków w obrębie małżeństwa i rodziny i poza nimi - w konfrontacji z formami życia, które nie przystają do wymogów przyszłości” (tamże).

Jak zauważa Irena Machaj, „należy podkreślić, że jeśli zmienia się relacja między kobietami a mężczyznami, to zmiana taka zawsze oznacza przesunięcia na skali równości - nierówności społeczne, co jest konsekwencją zwiększenia partycypacji np. kobiet $\mathrm{w}$ danym dobrze, $\mathrm{z}$ równoczesnym ograniczeniem np. uprzywilejowania mężczyzn w danym wymiarze zróżnicowania społecznego" (Machaj 2009: 16). Stąd niechęć do społecznych zmian, bo jedna z płci (przede wszystkim mężczyźni jako bardziej uprzywilejowani w tradycyjnym porządku) traci na rzecz tej drugiej. Także opór części kobiet wobec większego zaangażowania ojców w opiekę nad dziećmi może być wyjaśniany właśnie ich niechęcią do zmniejszenia swojej roli w rodzinie. Traktują one bowiem opiekę nad dzieckiem i niemal wyłączny dostęp do niego jako źródło władzy i swojej wyższości nad mężczyznami w prywatnej sferze (Badinter 1993: 157; Bullinger 1997: 198). Bronią niedostępnego dotąd mężczyznom obszaru, odtwarzając tym samym tradycyjny podział ról. Według G. Dencha uczestnictwo mężczyzn w życiu rodzinnym jest zawsze zapośredniczone przez kobiety, ponadto jedyną zachętą do ich zaangażowania jest przyznanie im roli głównego żywiciela rodziny i w związku z tym określonych przywilejów w sferze publicznej (Dench 1998). Odebranie im tego wyjątkowego stanowiska w związku z wkroczeniem kobiet na rynek pracy i postulatem równouprawnienia obu płci pociągnie za sobą, według autora, wycofanie mężczyzn i odrzucenie przez nich wszelkiej odpowiedzialności i obowiązków (tamże).

Trudność leży także w stworzeniu egalitarnej, demokratycznej rodziny opartej na równości jej członków. Magdalena Sternicka przyczyn takiego stanu rzeczy upatruje w procesie indywidualizacji oraz różnicach interesów, potrzeb, i wartości jednostek tworzących rodzinę, które mogą dążyć do zupełnie odmiennych celów i chcieć wprowadzać ,,własne porządki” (Sternicka 2008: 302). Biorąc pod uwagę sprzeczności między oczekiwaniami kobiet co do poziomu zaangażowania mężczyzn w wypełnianie obowiązków domowych i rodzicielskich a codzienną rzeczywistością, łatwo zauważyć, że negocjowanie rodzinnego układu, by był on satysfakcjonujący dla każdej ze stron, pozostaje fikcją. Kolejnym utrudnieniem jest fakt, że ,życie rodzinne jest poddane wpływom pracy zawodowej wykonywanej przez członków rodziny" (Szlendak 2010: 418) i to wymogi rynku pracy determinują poziom zaangażowania kobiet i mężczyzn w prace domowe oraz opiekę nad dziećmi (Beck 2002: 164; Kwak 2005: 27). 
Badacze wskazują, że zmiana kulturowego modelu kobiecości i męskości nie przebiega jednocześnie i w takim samym wymiarze. Pokazuje się na przykład, że stereotyp mężczyzny zmienia się wolniej, jest bardziej stabilny w porównaniu ze stereotypowym wizerunkiem kobiet (Mandal 2000: 20; Wojciechowska 2002: 160; Szarzyńska 2005: 50; Ostrouch 2004: 28). Z jednej strony „odporność na zmianę” męskiego stereotypu wyjaśnia się jego większą spójnością i silniejszym powiązaniem jego komponentów (Mandal 2000:20), z drugiej - jak zauważa Urlich Beck - „indywidualizacja (w sensie egzystencji urzeczywistnianej za pośrednictwem rynku) wzmacnia zachowania związane z rolą mężczyzny" (Beck 2002: 173-174). W związku z aktywnością zawodową kobiet w modelu kobiecości na znaczeniu zyskują cechy bardziej instrumentalne, potrzebne w pracy (Mandal 2000: 16). Nie idzie jednak za tym pojawienie się w stereotypie męskości cech uznawanych dotąd za kobiece, ponieważ w pozycji społecznej mężczyzn niewiele się zmieniło - nadal w małym stopniu angażują się w wykonywanie obowiązków domowych oraz rzadko wykonują zawody, w których dominują kobiety. Jak stwierdza Julita Wojciechowska, ,[...] badania pokazują zmianę w dystrybucji cech ocenianych jako kobiece lub męskie. I tak - w oczach badanych - kobiety stają się coraz bardziej męskie, mężczyźni jednak nie stają się bardziej kobiecy" (Wojciechowska 2002: 161). Ta zmiana $\mathrm{w}$ ramach modelu kobiecości stawia kobiety $\mathrm{w}$ trudnej sytuacji - oczekuje się od nich realizowania z poświęceniem roli matki, ale także bycia zaangażowanym pracownikiem, rezygnacja z którejś z ról naraża je na krytykę oraz jest powodem frustracji i niskiej samooceny. „Współczesna kobieta jest szczególnie podatna na frustrację: jeżeli zaangażuje się w pełni jako fachowiec, bierze na siebie ryzyko bycia nietypową i niekobiecą. Jeśli nie osiąga powodzenia w tradycyjnej roli, czuje się niespełniona jako osoba i kobieta. Jeśli podejmie obie role, nie ma pewności, czy wykonuje obie zadowalająco. Jeśli poprzestanie na tradycyjnej, jest rozgoryczona jako twórcza indywidualność" (Bardwick, Douvan 1982: 181-182). Zdaniem Lyndy M. Glennon, problem leży w socjalizacji dziewcząt, których nie przygotowuje się do spełniania stawianych przed nimi wymagań: kształtuje się $\mathrm{w}$ nich cechy tradycyjnie kobiece - ekspresyjne, a następnie w szkole i w pracy zawodowej oczekuje się od nich zachowań instrumentalnych (Glennon 1982: 148). Według Ellyn Kaschack, trudno określić, jakie właściwie powinny być nowoczesne kobiety, bo otrzymują one sprzeczne sygnały od otoczenia: spotykają się z negatywnymi ocenami zarówno gdy są „zbyt męskie” (nachalne, dominujące itp.), jak i w sytuacji gdy są ,zbyt kobiece" (gadatliwe, dokuczliwe, skupione na swoim wyglądzie, itp.), podczas gdy mężczyźni są krytykowani jedynie gdy zachowują się, mówią, czy wyglądają jak kobiety (Kaschack 1996: 52). Jak zauważa autorka, „,[...] w naszym społeczeństwie mężczyzna może zyskać aprobatę i uniknąć upokorzenia, zachowując się zgodnie ze społecznie ustalonymi wzorcami męskimi, ale dla kobiety ta nieskomplikowana opcja nie istnieje. Może ona zyskać podziw za właściwe (kobiece) zachowanie, ale często spotykają ją za nie takie same sankcje społeczne, jak w przypadku gdy zachowa się niewłaściwie (po męsku)" (tamże: 53). 
Brak zgodności w postrzeganiu kobiecości (jako tożsamej z męskością versus równej męskości lecz różnej) znajduje wyraz w różnych stanowiskach wobec macierzyństwa w ramach feminizmu (Humm 1993: 120; Budrowska 2000: 51 i n., 89 i n.; Malinowska 2000: 64; Slany 2008: 113; Gajewska 2008: 214 i n.). $\mathrm{Z}$ jednej strony mamy do czynienia z krytyką instytucji macierzyństwa jako opresyjnej dla kobiet i podtrzymującej patriarchalny porządek. Niekiedy przyjmuje to formę nienawiści wobec własnego kobiecego ciała i jego reprodukcyjnych funkcji (Uliński 2001: 289). Postuluje się możliwość realizowania kobiecości bez roli matki, w której upatruje się głównej przeszkody emancypacji kobiet (Gajewska 2008: 215). Z drugiej strony mamy nurty feministyczne afirmujące macierzyństwo jako indywidualne doświadczenie kobiety, niosące pozytywne konsekwencje dla jej rozwoju i osobowości (Budrowska 2000). Współcześnie określa się je mianem „,nowego feminizmu”, „feminizmu nowej kobiecości”, „feminizmu nowej tożsamości” czy też „feminizmu prorodzinnego" (Sobczyńska 1995: 83; Gawlina 2003: 38; Gawkowska 2008: 76). Nawiązują one do feminizmu różnicy, upatrując „esencji kobiecości” w „potencjale macierzyństwa”. - „Dla feminizmu nowej tożsamości istotne jest dowartościowanie kobiety w jej społecznej roli matki oraz afirmatywny stosunek do kobiecości także w jej wymiarze biologicznym, związanym z prokreacją" (Sobczyńska 1995: 83). W rezultacie takiego postrzegania kobiecości następuje niejako powrót do nakazu macierzyństwa, czy jego społecznego utrwalenia. Akceptuje się zawodową aktywność kobiet, ale oczekuje się jej zejścia na dalszy plan wobec obowiązków macierzyńskich. Stąd wyrzuty sumienia pracujących matek, które mimo że są przekonane co do szybkiego powrotu do pracy, mają świadomość, że oczekuje się od nich, by jednak bycie matką było chociaż w pierwszym okresie rozwoju dziecka ich rolą pierwszoplanową. Propagowana jest wspominana ideologia intensywnego czy totalnego macierzyństwa, utrudniająca, czy wręcz uniemożliwiająca kobietom aktywność pozadomową (Budrowska 2000: 165; Bradley 2008: 152, 163). Elisabeth Badinter w swojej najnowszej książce (Konflikt: kobieta i matka) ubolewa nad modą na „,naturalne” czy „ekologiczne” macierzyństwo, wymagające niemal całkowitego zaangażowania kobiety (wymóg karmienia piersią, stosowania ekologicznych pieluch, które trzeba prać oraz własnoręcznego przygotowywania obiadków) (Badinter 2013). Jej zdaniem prowadzi to do ponownego ,zamknięcia” kobiet w domu i zagraża już osiągniętemu w pewnym stopniu równouprawnieniu płci. „Społeczeństwo napiera na nie, by zapomniały o własnych potrzebach i spełniały wszystkie życzenia «żarłocznego i despotycznego dziecka, które pożera swoją matkę»" (Pszczółkowska 2010).

Na odpodmiotowienie kobiet będących matkami wskazuje Sylwia Urbańska analizująca poradnikowy dyskurs skierowany do młodych rodziców - głównie kobiet - w którym deprecjonuje się ich osobiste doświadczenia, wiedzę i umiejętności na rzecz wiedzy eksperckiej (Urbańska 2009; 2012). Profesjonalizacja rodzicielstwa czyni z matek i ojców bezradne, zagubione jednostki, które „wy- 
właszcza się" z własnego doświadczenia i wiedzy przekazywanej z pokolenia na pokolenie, dostarczając instruktażu dotyczącego niemal każdego aspektu bycia rodzicem: „począwszy od monopolu na definiowanie ideału macierzyństwa, sposobów prawidłowego odczuwania emocji, właściwych form okazywania emocji, po procesy psychofizyczne i wiele innych" (Urbańska 2009: 21, 25). Zdaniem autorki dotyczy to przede wszystkim kobiet i macierzyństwa, podczas gdy ojcu przyznaje się prawo do „kontrolowania i egzaminowania jakości prowadzonego przez matkę projektu wychowawczego" (tamże: 20-21).

Wolność wyboru jednostek i ich podmiotowość w nowoczesnym społeczeństwie często okazuje się pozorna. Hermann Bullinger analizując sytuację mężczyzn starających się realizować nowoczesny model rodzicielstwa, stwierdza, że „przemiana ojców” wynika nie z ich wewnętrznych potrzeb czy odczuwanego dyskomfortu psychicznego, lecz przede wszystkim jest rezultatem presji ze strony kobiet (Bullinger 1997: 19). Jego zdaniem ,[...] zmiany jakie w nich zaszły odbierane są jako coś obcego, wymuszonego i powierzchownego. Jeśli zabraknie tej presji, to grozi powrót dawnych zachowań" (tamże). Również Tomasz Szlendak zauważa instrumentalne podejście mężczyzn do nowego ojcostwa, które nie jest dla nich celem samym w sobie, lecz sposobem na usatysfakcjonowanie oczekującej jego zaangażowania kobiety i tym samym podtrzymanie ich intymnej relacji: „Mężczyzna znosi dzisiaj płacz dziecka, ponieważ nie chce, aby opuściła go partnerka. Im bardziej wartościowa jest dla niego partnerka, tym bardziej angażuje się w opiekę nad dziećmi" (Szlendak 2010: 452). Zdaniem H. Bullingera, niemożliwe jest pogodzenie bycia ,dobrym ojcem” (w nowoczesnym sensie - czułym, troskliwym i przede wszystkim zaangażowanym w pełni w życie rodzinne) z byciem „prawdziwym mężczyzną", tj. zgodnie z wciąż trwałym, wpojonym im, tradycyjnym wizerunkiem męskości, mężczyzną budującym swoją pozycję społeczną oraz tożsamość w oparciu o aktywność pozadomową (Bullinger 1997: 18-19). Wskazuje on, że zmiany w obu rolach - mężczyzny i ojca - nie zachodzą równocześnie i stąd ta sprzeczność (tamże: 21). Zauważa to także Harriet Bradley, pisząc: „młodzi mężczyźni opowiadają się za bardziej egalitarną ideą małżeństwa i dokładają starań, by być dobrymi ojcami, ale jednocześnie podlegają zewnętrznym presjom, by przybierać postawy i praktyki «męskości hegemonialnej»” (Bradley 2008: 163).

W literaturze przedmiotu wiele miejsca poświęca się rozważaniom na temat dylematów i trudności związanych z byciem mężczyzną we współczesnym społeczeństwie. Gdy tradycyjny wizerunek męskości zostaje zakwestionowany, wiadomo, jakim mężczyzną oraz ojcem nie powinno się być, ale brakuje pozytywnych wskazówek, na czym nowoczesna męskość i ojcostwo miałyby się opierać i w czym się przejawiać. Jak stwierdza Zbyszko Melosik, coraz trudniej odpowiedzieć na pytanie: „co oznacza być mężczyzną?” (Melosik 2002: 8). Współcześni mężczyźni muszą zmagać się z niepewnością i niepokojem związanym z budową własnej tożsamości i ,właściwością” własnych zachowań (Kluczyńska 
2009: 96). Jak zauważa Stephen Williams, odwołując się do wyników własnych badań przeprowadzonych wśród mężczyzn posiadających dzieci, współcześni młodzi ojcowie odrzucają wzory ojcostwa realizowane w ich rodzinach pochodzenia i zdają sobie sprawę, że nie mogą ich powielać, ale nie idzie za tym wiedza o tym, jacy mają być (Williams 2008: 500). „Podczas gdy wcześniej męskość była czymś oczywistym (niezależnie od tego, jak wiele wewnętrznej udręki mógł doznawać mężczyzna), teraz normy męskiego zachowania stały się czymś niejasnym” (Bradley 2008: 71). Zdaniem Kennetha J. Gergena określenie „prawdziwy mężczyzna" zaczęło nabierać znaczenia stosunkowo niedawno. Wcześniej rzadko się je słyszało, „bo rzeczywistość była niekwestionowana, a co za tym idzie, nie było o czym dyskutować" (Gergen 2009: 177). Odrzucenie tradycyjnego paradygmatu męskości jako ,jedynie słusznego" wywołało dyskusję na temat kryzysu męskości oraz kryzysu ojcostwa. Określanie męskości przez negację kobiecości, na czym opierał się tradycyjny model płci, nie wchodzi już w grę - nowy mężczyzna ma przecież pogodzić się ze swoją wewnętrzną kobiecością i pozwolić jej się ujawniać, co jednak nie może oznaczać zniewieścienia: „Dziś mężczyzna ma odkrywać w sobie kobietę, ale jednocześnie nią nie być!” (Kluczyńska 2009: 96). Według Urszuli Kluczyńskiej ten brak konkretnych wskazówek dotyczących oczekiwanej męskości powoduje, że „wyłania się typ mężczyzny zaniepokojonego, którego głównym problemem jest obawa o swoją męską adekwatność" (tamże). Nie bez znaczenia jest także fakt, że we współczesnych społeczeństwach wyżej zaczyna cenić się cechy związane z kobiecością (Hofstede 2000; Brannon 2002: 225; Malinowska 2003: 97). Jak podaje Lynda Brannon, „,...] wydaje się, że stwierdzane we wcześniejszych badaniach pozytywne postawy wobec mężczyzn i negatywne postawy wobec kobiet zaczynają ulegać zmianie. Nowsze badania wykazują, że wzrosła akceptacja dla elastyczności roli kobiecej, a stosunek do kobiet stał się bardziej pozytywny. Niektórzy badacze przekonują, że obecnie mężczyźni stali się obiektem silniejszej stereotypizacji i negatywnych ocen ze strony kobiet" (Brannon 2002: 225). Ewa Malinowska, za Geertem Hofstede, prognozuje „feminizację kultury” - rosnące znaczenie kobiecych wartości - z jednej strony w związku z zachodzącymi zmianami demograficznymi, technologicznymi oraz koniecznością dbałości o środowisko naturalne, z drugiej strony - jako efekt wzrostu udziału kobiet w sferze publicznej (Malinowska 2003: 97).

Obok pytań o istotę męskości pojawiły się także wątpliwości, na czym ma obecnie polegać rola ojca? „Czy jest on po prostu «drugą matką», czy też jego funkcja w życiu dziecka i rodziny naznaczona jest jakąś specyfiką?” (Krajewska 2008: 89). Podjęcie przez kobiety aktywności zawodowej odebrało mężczyznom funkcję jedynego żywiciela rodziny i łącznika ze światem zewnętrznym, społeczeństwem i sferą publiczną. Według autorów Historii ojców i ojcostwa (Delumeau, Roche 1995) początkiem kryzysu ojcostwa było zastąpienie władzy ojcowskiej władzą rodzicielską. Dziś, w związku z rozwojem medycyny i pojawieniem się możliwości sztucznego zapłodnienia, zakwestionowano samą istotę 
ojcostwa. „Kobieta może bez zgody, a nawet wiedzy biologicznego ojca, podjąć decyzję o samotnym macierzyństwie [...], pozbawiając go tym samym prawa do decydowania o dziecku” (Piątek 2007: 88). Ta „władza” kobiet nad mężczyznami wyraża się także w tym, że to od matek zależy poziom zaangażowania drugiego rodzica - kiedy i w jakim zakresie zostanie „,dopuszczony” do dziecka. Jak ujmuje to Małgorzata Sikorska, „ojciec może być na tyle ojcem, na ile pozwoli mu na to matka dziecka" (Sikorska 2009a: 203). W literaturze poświęconej roli ojca we współczesnym społeczeństwie mówi się o „cywilizacji bez ojca”, o ojcach nieobecnych, ginących czy niepotrzebnych, stawia się pytanie o „kres ojcostwa” (Delumeau, Roche 1995: 9; Gębka 2006: 117; Piątek 2007: 63; Budrowska 2008: 125; Sikorska 2009a: 191).

Tak jak w przypadku kobiet, również mężczyznom stawiane są „podwójne" oczekiwania - „stare”, wynikające z tradycyjnego modelu płci, oraz „,nowe” związane z nowym sposobem postrzegania kobiecości i męskości, macierzyństwa i ojcostwa. Jak zauważa Tomasz Szlendak, „[...] nowy ojciec jest figurą nieco bezradną i zestresowaną, ponieważ narzuca mu się sporo nowych wymagań, wcale nie eliminując starych. [...] Ma być z jednej strony mężczyzną "po staremu» i w związku z tą starą rolą agresywnie zarabiać, z drugiej zaś ma być łagodnym usypiaczem niemowląt cierpiących na kolkę" (Szlendak 2010: 451). Organizowane warsztaty dla ojców pokazują zapotrzebowanie na specjalne zajęcia rozwijające „ojcowskie" umiejętności, uświadamiające im znaczenie zaangażowania w opiekę nad dzieckiem i uczące, jak rozwijać silną więź z dzieckiem, ale tym samym świadczą o tym, że mężczyznom trudno jest się odnaleźć w „starej - nowej” roli. Potrzebują oni profesjonalnego wsparcia, konsultacji i porad innych osób, tym bardziej że młodym mężczyznom trudno naśladować własnych ojców funkcjonujących w innym modelu rodziny. W wyniku przemian społecznych i procesów indywidualizacji jednoznaczne i łatwe do zdefiniowania pojęcia macierzyństwa i ojcostwa przestają być oczywiste (Kwak 2005: 26). Obok siebie występuje wiele różnych odmian rodzicielstwa, różnych sposobów bycia matką, ojcem. Wśród mężczyzn znaleźć możemy na przykład ojców bezrobotnych, weekendowych, ojczymów, ale także ojców „patologicznych” (Dąbrowska 2004; 2007).

Podsumowując, we współczesnym społeczeństwie mamy do czynienia ze ścieraniem się tradycyjnego i nowoczesnego modelu płci, co prowadzi do dezorientacji i zagubienia kobiet i mężczyzn. „Gdy mówi się o strukturze współczesnych stosunków seksualnych, rodzicielskich i płci, to wydaje się konieczne podkreślenie wspólistnienia w nich trwałości i zmiany, niejasności i sprzeczności" (Elliot 1996, za: Kwak 2005: 53). Jednostka w nowoczesnym społeczeństwie może, a nawet musi wybierać sposób bycia sobą - jako kobietą/mężczyzną - ale musi zmierzyć się ze sprzecznymi często oczekiwaniami. Jak zauważają Judith M. Bardwick i Elisabeth Douvan, opisując sytuację współczesnych kobiet, co można także odnieść do mężczyzn: ,[...] kryteria tego, co akceptowalne, pożądane czy preferowane przestały być jasne - trudno starać się o tożsamość kobiecą, 
zdobywać poczucie własnej wartości, jeśli nie wiadomo, kiedy w istocie osiągnęło się cel. [...] wolność wyboru roli staje się jarzmem, gdy wybór jest możliwy, ale kryteria niejednoznaczne; w takich okolicznościach niezwykle trudno rozpoznać, kiedy osiągnęło się kobiecość, a kiedy się ją wystawiło na szwank" (Bardwick, Douvan 1982: 181-182). W postawach współczesnych kobiet i mężczyzn można zauważyć pewne rozdwojenie, zawieszenie pomiędzy oboma modelami płci. Pokazują to na przykład wyniki badań młodych mężczyzn wypowiadających się na temat ról kobiet, którzy „z jednej strony popierają emancypację kobiet i równouprawnienie, a z drugiej pragną zachować tradycyjne relacje płci w rodzinie" (Cicha 2006: 175). Jak zauważa Krzysztof Arcimowicz na przykładzie męskości, zmiana kulturowych konstruktów płci (można to odnieść do zmian modeli i wzorów kulturowych w ogóle) nie polega na ich „wymianie”, ale prowadzi do konkurowania ze sobą „starego" i „nowego" i co za tym idzie, z jednej strony do dezorientacji jednostek, z drugiej strony występowania paradoksów rzeczywistości społecznej. - „Nowe modele ról mężczyzn nie zastępują tradycyjnych, ale rosną obok nich, tworząc dynamiczne naprężenia między ambitnym żywicielem rodziny a współczującym ojcem, między uwodzicielem a kochającym partnerem [...]. Obecnie mężczyźni rozwijają szerszy niż to miało miejsce wcześniej repertuar uczuć w związkach z kobietami, ale jednocześnie przemoc wobec kobiet (gwałty, napaść seksualna, przemoc fizyczna) i homofobia wydają się nasilać" (Arcimowicz 1998: 4). O tej koegzystencji tradycyjnego i nowoczesnego modelu kobiecości i męskości świadczą wyniki analizy dyskursów społecznych dotyczącej szeroko pojętej problematyki genderowej ${ }^{10}$, pokazujące różnorodność wzorów ról rodzicielskich oraz płciowych. W medialnym obrazie kobiet i mężczyzn, matek i ojców tradycja miesza się z nowoczesnością. Zwolennikom różnych sposobów postrzegania kobiet i mężczyzn oraz relacji między płciami trudno dojść do porozumienia, co rodzi określone problemy zarówno w mikroskali życia społecznego, jak i na poziomie makrostrukturalnym. Stawiane kobietom i mężczyznom oczekiwania płynące $\mathrm{z}$ dwóch konkurencyjnych modeli płci są sprzeczne, utrudniając ich codzienne funkcjonowanie.

${ }^{10} \mathrm{Na}$ przykład dyskurs nierównościowy versus dyskurs równościowy w debacie publicznej (Bator 1999); dyskurs odwołujący się do „prawdziwej męskości” versus dyskurs „rozpraszający kategorię różnicy płci” w kulturze popularnej (Melosik 1996: 218, za: Dziekanowska 2008: 61; Szczepaniak 2005: 34); dyskursy medialne poświęcone macierzyństwu i ojcostwu w ich różnych współczesnych odmianach (Szulich-Kałuża 2008; Dzwonkowska-Godula 2011; Arcimowicz 2007; 2010; 2011; Łaciak 2007; 2012; Stańczak-Wiślicz 2012). 


\section{Rozdział 4. Modele i wzory kobiecości i męskości, macierzyństwa i ojcostwa funkcjonujące w społeczeństwie polskim}

\subsection{Współczesne polskie społeczeństwo jako kontekst podmiotowych działań jednostek. Koncepcja roli matki i roli ojca w polskiej polityce rodzinnej}

Rozwijając koncepcję podmiotowości jednostki A. Giddens podkreślał, że społeczni aktorzy działają w określonych warunkach historycznych, które wpływają na zakres ich podmiotowości. By móc ocenić, czy młodzi wykształceni Polacy $\mathrm{w}$ swoich rolach rodzicielskich odtwarzają tradycyjny model płci, czy realizując nowoczesne wzory macierzyństwa i ojcostwa, dokonują jego zmiany, niezbędne jest przyjrzenie się społecznemu kontekstowi, w jakim funkcjonują. Przybliżymy tutaj najistotniejsze cechy polskiego społeczeństwa, by następnie skupić się na roli dwóch instytucji odgrywających znaczącą rolę w społecznym definiowaniu ról płciowych i rodzicielskich, tj. państwa i Kościoła katolickiego.

Analiza możliwości dokonywania indywidualnych wyborów przez jednostki wymaga przyjrzenia się trzem, powiązanym ze sobą, wymiarom ładu społecznego: politycznemu, ekonomicznemu oraz kulturowemu (Ziółkowski 2006: 156, 157; Inglehart, Norris 2009). W sferze politycznej upodmiotowieniu społecznych aktorów sprzyja liberalna demokracja, „likwidująca zewnętrzne ograniczenia dokonywania wyborów przez jednostki, umożliwiając im uzyskanie «wolności od» (czyli wolności negatywnej)" (Ziółkowski 2006: 157). W niedemokratycznym społeczeństwie jednostki pozbawione są autonomii, narzuca im się kolektywne tożsamości, nie zostawiając możliwości samookreślenia się i projektowania własnego życia (Malinowska 2000: 123). Według wyników sondażu CBOS, Polacy utożsamiają demokrację przede wszystkim z wolnością, swobodami obywatelskimi oraz równością (CBOS 2013b). Zdaniem większości wartości te (z wyjątkiem równości) funkcjonują w polskim społeczeństwie (tamże). Wśród Polaków dominuje także przekonanie, że w państwie demokratycznym wyższa jest ogólnie pojęta jakość życia: ludzie czują się bardziej wolni, są na ogół szczęśliwsi i zamożniejsi niż w systemie niedemokratycznym (CBOS 2009a). Wolność jednostki oznacza możliwość „tworzenia, kształtowania świata własnego i świata wspólnego według swoich wyobrażeń" (Król 1999: 145).

W wymiarze ekonomicznym podmiotowości jednostek sprzyja wolnorynkowa gospodarka z podstawowymi zasadami prywatnej własności i wolnej konkurencji. Poza liberalnymi zasadami istotny jest także poziom rozwoju gospodarczego 
- ,wzrost gospodarczy zapewnia pomnażanie indywidualnych zasobów i większą możliwość wydawania dochodów na wybrane przez siebie cele" (Ziółkowski 2006: 157). Ponadto indywidualny dobrostan pociąga za sobą orientację na określone wartości, a w rezultacie wpływa na działania jednostek, wyznaczane sobie przez nie cele. Jak pokazują międzykulturowe badania R. Ingleharta, w biednych społeczeństwach jednostki na pierwszym miejscu stawiają zaspokojenie podstawowych potrzeb, koncentrują się na wartościach materialnych, nazywanych ,wartościami niedostatku", dotyczących poziomu życia i bezpieczeństwa socjalnego (Siemieńska 2004: 179; Ziółkowski 2006: 157; Bartkowski 2009: 35; Inglehart, Norris 2009: 25, 27). W warunkach dobrobytu i bezpieczeństwa ekonomicznego natomiast ludzie skłaniają się ku wartościom postmaterialistycznym, określanym przez autora mianem ,potrzeb ekspresji” (tamże). W polskim społeczeństwie obserwuje się dominację orientacji materialistycznej - ,pragmatyzację świadomości”, wyrażającej się w koncentracji na własnej sytuacji materialnej i pozycji społecznej (Ziółkowski 2006: 161, 165). Wiąże się to z takimi zjawiskami jak złe warunki życia części społeczeństwa, ekonomiczne zróżnicowanie i pogłębiająca się polaryzacja społeczna, wzrost niepewności, niskie bezpieczeństwo pracy itp. (tamże; Siemieńska 2004: 203).

W wymiarze kulturowym o społeczeństwie wyboru można mówić w warunkach kulturowej wolności - pluralizmu i tolerancji wobec różnych stylów życia, uznawania różnych pragnień, potrzeb i aspiracji (Ziółkowski 2006: 157). Pluralizm jest cechą demokracji, konsekwencją wolności jednostek, jednak musi mu towarzyszyć społeczne przyzwolenie na istnienie odmienności, postawa otwartości i szacunku dla Innego. Marek Ziółkowski analizując system wartości polskiego społeczeństwa w wymiarze społeczno-kulturowym, stwierdził skłanianie się Polaków bardziej ku „kulturowemu porządkowi” niż „kulturowej wolności” (Ziółkowski 2006: 166-167). Przejawia się to w hołdowaniu raczej wartościom tradycyjnym, „zakazującym i hamującym” (prostota, dyscyplina, konformizm, podporządkowanie) niż „libertariańskim” (pluralizm, swoboda, tolerancja, samopobłażanie) (tamże: 166-167). Jednocześnie jednak autor zauważył, że „nasila się ogólna tendencja do ujmowania rozmaitych norm nie tyle jako bezwzględnych nakazów, ile raczej jako preferencji bądź przyzwolenia" (tamże: 168). Także wyniki sondaży CBOS świadczą o powolnym wzroście „liberalizmu moralnego” wśród Polaków (CBOS 2010, 2013c).

Jeżeli przyjmiemy, że pełnią podmiotowości, wolnością i autonomią w samookreślaniu się i rozmaitych życiowych wyborach cieszą się jednostki rozumiejące zasady demokracji i wolnorynkowej gospodarki i potrafiące z nich korzystać, zorientowane na wartości postmaterialistyczne, wykazujące się postawą otwartości i tolerancji, wyniki badań przeprowadzonych w polskim społeczeństwie pozwalają stwierdzić, że polskie społeczeństwo dla dużej części jej członków jest raczej społeczeństwem losu, nie wyboru (Ziółkowski 2006: 157). Do osób o stosunkowo wysokim stopniu podmiotowości można natomiast zaliczyć młodych, 
wykształconych, aktywnych zawodowo mieszkańców dużych miast, do których należą uczestnicy badania zrealizowanego na potrzeby pracy. Oni bowiem, jak pokazują wyniki badań, są zwolennikami demokracji i obyczajowej liberalizacji oraz postmaterialistami, nastawionymi na jakość życia, autonomię jednostki, swobodną ekspresję, akceptującymi pluralizm wartości i różnorodne style życia (Siemieńska 2004: 203; Ziółkowski 2006: 167; CBOS 2010, 2013c). Można zakładać, że będą oni dążyć do realizacji wyznawanych wartości, przede wszystkim zaś korzystać z możliwości indywidualnego wyboru, jakie daje im społeczeństwo.

W analizie społecznego kontekstu, w jakim młodzi wykształceni Polacy dokonują wyboru sposobu pełnienia ról rodzicielskich, istotne jest przyjrzenie się kulturowym modelom płci propagowanym przez państwo oraz Kościół katolicki. Obie te instytucje, dysponując rozmaitymi środkami, mają wpływ na realizowane przez jednostki wzory kobiecości i męskości, macierzyństwa i ojcostwa.

Jak stwierdza Harriet Bradley, „płeć jest kształtowana politycznie” (Bradley 2008: 17). Państwo odgrywa ważną rolę w podtrzymywaniu lub redefiniowaniu reguł dotyczących relacji płci. Zdaniem Renaty Siemieńskiej to „trzeci partner” odgrywający rolę w ustalaniu kontraktu między kobietami i mężczyznami (Siemieńska 2007a: 307).

Za różnego rodzaju rozporządzeniami, ustawami, przepisami kryje się określony sposób rozumienia kobiecości i męskości. Badacze podkreślają wpływ polityki społecznej na „treść życia rodzinnego”, możliwość pobudzania zmian w określonym kierunku, na przykład równouprawnienia małżonków bądź odwrotnie - podtrzymywania tradycyjnego podziału ról w rodzinie (Turnowiecki 2009: 165). Dotyczy to także, a może przede wszystkim, polityki rodzinnej odwołującej się do biologicznych ról kobiet i mężczyzn - ról rodzicielskich. Jednostek w rodzinnych rolach dotyczą także liczne uregulowania prawne, począwszy od Konstytucji, w której w art. 18 czytamy: „Małżeństwo jako związek kobiety i mężczyzny, rodzina, macierzyństwo i rodzicielstwo znajdują się pod ochroną i opieką Rzeczypospolitej Polskiej”, a w art. 33: „Kobieta i mężczyzna w Rzeczypospolitej Polskiej mają równe prawa w życiu rodzinnym, politycznym, społecznym i gospodarczym" (Konstytucja 1997). Oficjalna społeczna wizja rodziny, wewnątrzrodzinnych ról i stosunków zawarta jest w Kodeksie rodzinnym i opiekuńczym, który „opiera się na czterech filarach: trwałości małżeństwa, równouprawnienia małżonków, ochrony dziecka oraz wzajemnej pomocy członków rodziny" (Turnowiecki 2009: 168).

Politykę rodzinną państwa definiuje się jako „działania rządu na rzecz dzieci i ich rodzin, a zwłaszcza taką politykę państwa, której celem jest wywarcie wpływu na sytuacje rodzin posiadających dzieci lub poszczególnych osób w ich rolach rodzinnych" (Kamerman 1994, za: Firlit-Fesnak 2007: 188). Konieczność wspierania rodziny przez państwo uzasadnia się jej ważnymi społecznie funkcjami utrzymywania ciągłości biologicznej oraz kulturalnej społeczeństwa (Szczepański 1970: 303, 304). Do celów polityki rodzinnej należy tworzenie odpowiednich 
warunków do powstania i rozwoju rodziny oraz spełniania przez nią wszystkich funkcji, zaspokajanie jej bytowych i kulturalnych potrzeb, zapewnienie optymalnych warunków kształcenia i wychowania młodego pokolenia oraz równości szans życiowych (Kurzynowski 1991, za: Balcerzak-Paradowska 2004a: 139). Jeżeli za teoretyczną podstawę polityki rodzinnej państwa przyjmiemy ekonomiczną teorię dzietności Gary'ego Beckera, według której dzieci traktowane są jako „dobro" o określonej użyteczności i jednostki, podejmując decyzję o powiększeniu rodziny, biorą pod uwagę koszty i korzyści związane z posiadaniem dziecka, wówczas głównym celem polityki rodzinnej byłoby zmniejszenie kosztów wychowania dzieci (Wóycicka 2005: 79). Chodzi tu zarówno o koszty bezpośrednie, jak i pośrednie oznaczające utratę dochodów z pracy w związku z okresową dezaktywizacją zawodową rodzica (głównie matki) lub zmniejszeniem wymiaru pracy w celu opieki nad dzieckiem (tamże).

Tutaj przedmiotem zainteresowania są te instrumenty polityki rodzinnej państwa, które dotyczą łączenia obowiązków rodzinnych i zawodowych. Irena Wóycicka zalicza do nich urlopy macierzyńskie (rodzicielskie) i wychowawcze, dostępne formy opieki nad dzieckiem oraz organizację pracy (elastyczny czas pracy, niepełny wymiar) (Wóycicka 2005: 80). Bożena Balcerzak-Paradowska wymienia natomiast świadczenia społeczne: pieniężne oraz w naturze (rzeczowe, usługi społeczne), system podatkowy (ulgi na określone grupy wydatków, np. na opiekę nad dzieckiem) oraz rozwiązania dotyczące uprawnień pracowniczych (prawo pracy), czasu i organizacji pracy (Balcerzak-Paradowska 2004a: 145). Trzeba zauważyć, że wprowadzenie powyższych rozwiązań jest uwarunkowane czynnikami demograficznymi, społecznymi, ekonomicznymi i kulturowymi. Polityka państwa na rzecz rodziny - jej cele oraz środki - zmieniały się wraz ze zmianami $\mathrm{w}$ procesie reprodukcji ludności (możliwości kontroli płodności, spadek dzietności), sytuacji na rynku pracy (aktywizacja zawodowa kobiet, bezrobocie i zagrożenie ubóstwem), zmianą podziału ról w rodzinie, pojawieniem się alternatywnych form życia rodzinnego (np. rodziny niepełne, rodziny zrekonstruowane) (Firlit-Fesnak 2007: 188, 189). Pierwsze działania z zakresu polityki rodzinnej państwa (w Europie na przełomie XIX i XX w.) koncentrowały się na problemach związanych z niskim przyrostem naturalnym oraz ubóstwem i ograniczały się do świadczeń pieniężnych mających złagodzić trudności ekonomiczne rodzin z dziećmi (Balcerzak-Paradowska 2004a: 145). Konieczność włączenia do polityki rodzinnej rozwiązań mających na celu łagodzenie konfliktu między obowiązkami rodzinnymi i zawodowymi pojawiła się wraz z masowym wejściem kobiet na rynek pracy i upowszechnianiem się modelu rodziny z dwojgiem pracujących rodziców (tamże: 153). W Polsce wprowadzono wówczas system ochrony pracy kobiet $\mathrm{w}$ ciąży oraz urlopy macierzyńskie, tworzono żłobki i przedszkola, zobowiązywano do ich prowadzenia także zakłady pracy (Warzywoda-Kruszyńska 2004: 18). Jednak problem łączenia roli rodzicielskiej i zawodowej traktowano jako dotyczący jedynie kobiet - ,[...] przez cały okres realnego socjalizmu usta- 
wodawstwo pracy podtrzymywało tradycyjny podział ról w rodzinie stanowiąc, że jedynie matka jest uprawniona do opieki nad dzieckiem. Ojciec postrzegany był jako osoba pomagająca matce, zastępująca ją tylko wówczas, gdy wskutek choroby lub obowiązków służbowych kobieta nie mogła zaopiekować się dzieckiem" (tamże). Obecnie wciąż powszechny jest ekonomiczny model rodziny z podwójnym obciążeniem kobiet, w którym oboje rodzice pracują zawodowo, ale zaangażowaniu kobiety na rynku pracy towarzyszy obciążenie obowiązkami domowymi (dual earner - double burden of women model). Jednak coraz częściej preferowany jest (rzadziej realizowany) model partnerski, w którym aktywność rodzinna oraz zawodowa są przez oboje pracujących małżonków (partnerów) traktowane równolegle (dual earner - dual carer model) (CBOS 2013a; Kotowska 2005: 30). Zatem w dyskusji o godzeniu obowiązków zawodowych i rodzinnych trzeba odejść od przyjmowania jedynie perspektywy kobiety, matki i pracownika, i zacząć uwzględniać perspektywę obojga rodziców (Kotowska 2005: 41; Kotowska i in. 2007: 466), co zresztą wydaje się być już wzięte pod uwagę w najnowszych przepisach wprowadzonych w Polsce w 2013 roku. „Polityka rodzinna powinna sprzyjać łączeniu podstawowych aktywności życiowych - zawodowej i rodzinnej. W warunkach współczesnego rynku pracy oznacza to politykę zorientowaną na rodzinę z pracującymi rodzicami, którzy wspólnie odpowiadają za obowiązki rodzinne" (Kotowska 2005: 41). Takie ujęcie odpowiada polityce Unii Europejskiej promującej „zrównoważony udział pracujących kobiet i mężczyzn w życiu rodzinnym" i wprowadzającej urlopy rodzicielskie przysługujące obojgu pracującym rodzicom (Dyrektywa 96/34/WE z 3 czerwca 1996 r., za: Firlit-Fesnak 2005: 184).

Wśród rozwiązań polskiej polityki rodzinnej na rzecz łączenia obowiązków rodzinnych i zawodowych można wyróżnić te przysługujące tylko kobietom z racji „biologicznej funkcji macierzyństwa” - są to uprawnienia w okresie ciąży, porodu oraz karmienia piersią (Balcerzak-Paradowska 2004a: 228, 250; 2005: 96). W związku z ochroną macierzyństwa obowiązuje zakaz zatrudniania kobiety w ciąży przy pracach szczególnie uciążliwych dla zdrowia, w porze nocnej oraz godzinach nadliczbowych, a także delegowania jej poza stałe miejsce pracy. Pracodawca nie może wypowiedzieć ani rozwiązać z nią umowy o pracę, a umowę zawartą na czas określony musi przedłużyć do dnia porodu. Ma także obowiązek udzielenia pracownicy w ciąży zwolnienia od pracy na przeprowadzenie badań lekarskich, oraz wypłacenie jej przysługującego za okres zwolnienia wynagrodzenia. Kobiety karmiące dzieci piersią mają prawo do dwóch półgodzinnych przerw w pracy.

Podstawowym instrumentem polityki rodzinnej państwa mającym łagodzić konflikt między aktywnością zawodową i rodzinną są urlopy macierzyńskie i wychowawcze oraz związane z nimi świadczenia finansowe (Kodeks pracy, Dział 8). Od roku 2013 przysługujący Polkom urlop macierzyński dzieli się na część podstawową (obligatoryjną) w wymiarze 20 tygodni oraz część dodatkową (fakultatywną) 
w wymiarze sześciu tygodni ${ }^{1}$ (http://www.rodzicielski.gov.pl/, 01.11.2014). Pierwsze 14 tygodni urlopu podstawowego może wykorzystać tylko kobieta, pozostała część urlopu, jeżeli zrezygnuje z niej matka, może zostać wykorzystana przez ojca. Dotyczy to także dodatkowego urlopu macierzyńskiego. Ojcu dziecka przysługuje dwutygodniowy urlop („,ojcowski”) do wykorzystania w dowolnym okresie w ciągu roku od narodzin dziecka. Pracownik ma prawo do wykorzystania urlopu ojcowskiego również w tym samym czasie, kiedy z urlopu macierzyńskiego będzie korzystać matka dziecka. W czasie urlopu macierzyńskiego i ojcowskiego przysługuje zasiłek odpowiadający wynagrodzeniu osoby korzystającej z tego uprawnienia. Rodzice mogą wydłużyć czas opieki nad dzieckiem o kolejne 26 tygodni urlopu rodzicielskiego ${ }^{2}$. Może korzystać z niego i matka i ojciec, wymieniając się opieką nad dzieckiem, sprawując ją równocześnie lub łącząc korzystanie z urlopu z pracą na nie więcej niż pół etatu (tamże). Wysokość otrzymywanego zasiłku w czasie urlopu macierzyńskiego i rodzicielskiego zależy od „wyboru ścieżki uzyskiwania urlopów związanych z urodzeniem się dziecka"3.

Pracujący rodzice mają także możliwość wzięcia niepłatnego urlopu wychowawczego w wymiarze 36 miesięcy. By otrzymać zasiłek wychowawczy trzeba spełnić określone kryteria dochodowe. Pracownikom posiadającym dzieci przysługuje także zwolnienie na opiekę nad chorym dzieckiem wraz z zasiłkiem opiekuńczym (Balcerzak-Paradowska 2004a: 228, 229). Instrumentem kompensującym koszty związane z wychowaniem dziecka, obok świadczeń rodzinnych, są także ulgi podatkowe. W 2007 roku wprowadzono ulgę podatkową na dzieci, nazywaną także ulgą rodzinną, pozwalającą podatnikom, którzy w roku podatkowym wychowywali własne lub przysposobione dzieci, odliczyć od podatku określoną kwotę na każde dziecko (https://rodzina.gov.pl/swiadczenia/ulgi-dla-rodziny, 01.11.2014).

Wyniki badań pokazują, że w Polsce zmniejsza się odsetek osób korzystających z urlopów wychowawczych (Balcerzak-Paradowska 2004a: 252; 2008: 20). Wskazuje się tu kilka przyczyn. Po pierwsze, dla większości rodzin korzystanie

${ }^{1}$ Mowa tu o urlopie przysługującym w przypadku urodzenia jednego dziecka. Zarówno podstawowy, jak i dodatkowy urlop macierzyński są dłuższe w przypadku narodzin więcej niż jednego dziecka.

${ }^{2}$ Urlop rodzicielski przysługuje bezpośrednio po wykorzystaniu przed nim dodatkowego urlopu macierzyńskiego w pełnym wymiarze. Można go wykorzystać w pełnym albo niepełnym wymiarze, w jednej, dwóch lub trzech częściach. Części te nie muszą być równe, ale każda z nich musi obejmować minimum 8 tygodni i następować bezpośrednio po części ją poprzedzającej (http:// www.rodzicielski.gov.pl/, 01.11.2014).

${ }^{3} \mathrm{~W}$ przypadku decyzji podjętej w ciągu dwóch tygodni po porodzie o wykorzystaniu urlopu macierzyńskiego i rodzicielskiego w pełnym wymiarze, zasiłek wynosi $80 \%$ wynagrodzenia przez cały okres urlopu. W sytuacji gdy wniosek o urlop rodzicielski zostanie złożony później, wysokość zasiłku wynosi 100\% wynagrodzenia za okres podstawowego i dodatkowego urlopu macierzyńskiego oraz 60\% za okres urlopu rodzicielskiego (http://www.rodzicielski.gov.pl/, 01.11.2014). 
z urlopu wychowawczego przez jednego z rodziców oznacza utratę jego dochodów, do zasiłków wychowawczych mają bowiem prawo osoby spełniające określone kryteria dochodowe, co sprawia, że świadczenia te są adresowane do osób i rodzin ubogich. Po drugie, wysokość zasiłków wychowawczych nie rekompensuje utraty zarobków korzystającego z urlopu rodzica. Po trzecie, wskazuje się na niechęć pracodawców do wykorzystywania przez pracowników urlopów wychowawczych, oznaczających ich przedłużającą się nieobecność w pracy (Balcerzak-Paradowska 2004a: 252; 2008: 20; Muczyński, Żynel 2006: 56). Po czwarte, urlopy wychowawcze w Polsce nie są elastyczne - nie można ich łączyć z pracą w niepełnym wymiarze godzin, jeżeli pobiera się zasiłek wychowawczy (Wóycicka 2005: 86). Poza tym urlop wychowawczy trzeba wykorzystać do czasu ukończenia przez dziecko piątego roku życia, podczas gdy na przykład w Szwecji, Austrii, Danii czy Holandii z prawa do urlopu wychowawczego w określonym wymiarze można korzystać dopóki dziecko nie jest samodzielne (tamże). Takie rozwiązanie jest bardziej dostosowane do indywidualnych potrzeb rodziny, ponadto możliwość dzielenia urlopu wychowawczego na krótsze okresy na przestrzeni kilkunastu lat nie powoduje długiej dezaktywizacji zawodowej kobiet. Irena Wóycicka podkreśla także znaczenie indywidualizacji świadczenia, oznaczającej brak przechodniości uprawnienia pomiędzy kobietami i mężczyznami - niewykorzystany przez mężczyznę urlop lub jego część nie może być wykorzystany przez kobietę (tamże). ${ }^{4}$ Dzięki takiemu rozwiązaniu (stosowanemu m.in. w Norwegii, Szwecji, Danii i Austrii) matki wcześniej wracają do pracy, gdy z dzieckiem zostają ojcowie, ponadto „ryzyko macierzyństwa (ojcostwa) jest równiej rozłożone między płci” (tamże).

Należy podkreślić, że wprowadzane zmiany w zakresie opisywanych uprawnień polegały $\mathrm{w}$ dużej mierze na ich rozszerzeniu na mężczyzn i umożliwieniu obojgu rodzicom opieki nad dziećmi. Zdaniem B. Balcerzak-Paradowskiej „wynikało to zarówno z realizacji zasady równości i równouprawnienia, jak również $\mathrm{z}$ dążenia do wzmocnienia pozycji kobiet na rynku pracy oraz ugruntowania roli ojca jako opiekuna" (Balcerzak-Paradowska 2008: 20). Jak podkreśla jednak autorka, „zmiany normatywne wyprzedziły znacznie procesy realne”, bo to nadal przede wszystkim kobiety korzystają z tych uprawnień i są postrzegane przez pracodawców jako ich adresatki (tamże: 20,21). Na przykład z urlopu rodzicielskiego

${ }^{4}$ W świetle obecnie obowiązujących przepisów, ,każdemu z rodziców lub opiekunów dziecka przysługuje wyłączne prawo do jednego miesiąca urlopu wychowawczego z wymiaru 36 miesięcy (w przypadku chęci skorzystania z pełnego wymiaru urlopu wychowawczego, 35 miesięcy tego urlopu będzie mogła wykorzystać na przykład mama dziecka, natomiast jeden miesiąc tego urlopu przypadnie jego tacie). Prawa tego nie można przenosić, co oznacza, że żaden z rodziców lub opiekunów dziecka nie będzie mógł zrezygnować z należnego mu miesiąca na rzecz drugiego rodzica lub opiekuna" (http://www.rodzicielski.gov.pl/, 01.11.2014). 
korzysta zaledwie 2\% ojców (Kostrzewski, Miączyński 2014). Jak pokazują badania Eurostatu, najczęstszymi powodami rezygnacji z urlopu przez ojców są: niewiedza na temat przysługujących świadczeń, przekonanie o możliwym pogorszeniu sytuacji finansowej rodziny oraz traktowanie opieki nad dziećmi jako roli kobiety (Chełstowska, Zarzyńska 2014: 28). W badaniu sondażowym przeprowadzonym w 2012 r. przez TNS OBOP na zlecenie „Gazety Wyborczej”, w odpowiedzi na pytanie dlaczego urlopy dostępne dla ojców są w Polsce nadal mało popularne, „blisko $43 \%$ ankietowanych stwierdziło, że «rodzina traciłaby na tym finansowo», 29\% - że «ojcowie sądzą, że matki zajmą się dziećmi lepiej», 26\% - że «to sprzeczne z naszą tradycją», 21\% - że «ojcowie sądzą, że nie podołaliby obowiązkom»" (tamże). Paweł Kubicki zwraca uwagę, że problem może leżeć także po stronie kobiet: „wiele matek potrzebuje bowiem dodatkowej motywacji, by podzielić się dzieckiem z ojcem na zasadach partnerskich" (Kubicki 2009: 95). Ponadto autor zauważa, że po dłuższym okresie sprawowania opieki nad dzieckiem przez matkę trudno jest „odwrócić role”, także dlatego że ojcowie nie są „wdrożeni” we wszystkie czynności pielęgnacyjno-opiekuńcze, mają obawy przed zostaniem z małym dzieckiem „sam na sam” (tamże: 94). Pomóc mogłoby tu wykorzystywanie urlopu ojcowskiego zaraz po narodzinach dziecka (jest taka możliwość), „by ojciec szybciej nawiązał z nim kontakt i szybciej zdobył doświadczenia związane z opieką nad nim" (tamże). Innym rozwiązaniem mogłoby być wprowadzenie specjalnego „urlopu okołourodzeniowego dla ojców umożliwiającego mężczyznom aktywniejsze uczestniczenie w przygotowaniach do narodzin dziecka i opiece nad dzieckiem" (Growiec 2008: 6). Eksperci wskazują, że przyczyną małego zainteresowania mężczyzn urlopami na opiekę nad dzieckiem może być także lęk przed reakcją pracodawcy i utrudnienia z jego strony (Chełstowska, Zarzyńska 2014: 28; Kostrzewski, Miączyński 2014). Rozwiązaniem mogłoby być zarezerwowanie części urlopu rodzicielskiego i wychowawczego tylko dla mężczyzn, niemożność wzięcia jej przez matki. Jak się bowiem okazuje, ,rozwiązania neutralne płciowo (na przykład urlop rodzicielski do dowolnego podziału między rodzicami), umacniają jedynie tradycyjny podział ról, ponieważ z urlopu tego korzysta zwykle kobieta (Chełstowska, Zarzyńska 2014: 29).

W przypadku niepłatnych urlopów wychowawczych, istotny jest fakt wyższych zarobków mężczyzn w porównaniu z wynagrodzeniami kobiet, który powoduje, że „okresowa dezaktywizacja zawodowa mężczyzny czy nawet korzystanie przez niego ze zwolnienia opiekuńczego pociąga za sobą większy uszczerbek dla dochodów rodziny" (Balcerzak-Paradowska 2004a: 251). Tym bardziej że - jak pokazują międzynarodowe badania - to właśnie najlepiej zarabiający mężczyźni, wysoko wykształceni specjaliści stosunkowo najczęściej popierają równość płci i wyrażają chęć zaangażowania w opiekę nad dzieckiem, jednak pod warunkiem, że „nadmiernie nie obciąży to finansowo ich rodzin” (Saxonberg 2010: 106).

Mimo wprowadzonych zmian w przepisach dotyczących łączenia aktywności rodzinnej i zawodowej w kierunku angażowania obojga rodziców w obie te sfe- 
ry, wciąż aktualna wydaje się diagnoza Bożeny Balcerzak-Paradowskiej sprzed dziesięciu laty, która stwierdziła: „,...] można oceniać, że rozwiązania z zakresu polityki rodzinnej uwzględniają model rodziny z dwojgiem pracujących rodziców oraz opierają się na zasadzie równości kobiet i mężczyzn. Nie przekłada się to jednak na zasadnicze zmiany modelu rodziny opartego na partnerstwie zarówno w sferze pracy, jak i w sferze obowiązków wewnątrzrodzinnych" (Balcerzak-Paradowska 2004a: 255). Mimo równości praw obojga rodziców z uprawnień korzystają głównie kobiety i w przekonaniu pracodawców są kłopotliwymi pracownikami, obciążającymi ich kosztami oraz problemami natury organizacyjnej związanymi z urlopami macierzyńskimi, wychowawczymi czy zwolnieniami opiekuńczymi (Balcerzak-Paradowska 2005: 98). W rzeczywistości rozwiązania mające ułatwiać godzenie obowiązków zawodowych z rodzinnymi zmniejszają konkurencyjność kobiet na rynku pracy w porównaniu z mężczyznami. Analiza postaw pracodawców wobec zatrudnionych pokazuje, że „kobiety są postrzegane przez pracodawców jako potencjalne matki, natomiast mężczyźni nie są postrzegani jako potencjalni ojcowie (Kotowska, Giza-Poleszczuk 2010: 67). To może też stanowić barierę powstrzymującą mężczyzn przed korzystaniem z przysługujących im uprawnień rodzicielskich, $\mathrm{w}$ związku $\mathrm{z}$ ich obawami przed negatywną oceną ze strony pracodawcy i posądzeniem o „brak ambicji” (Saxonberg 2010: 107).

Innym niezwykle ważnym elementem polityki rodzinnej mającym ułatwiać godzenie obowiązków rodzinnych i zawodowych jest dostęp do usług społecznych związanych z opieką nad dzieckiem - żłobków, przedszkoli, świetlic dla dzieci. Dane statystyczne wskazują na niewystarczającą liczbę placówek opiekuńczych w Polsce oraz niski odsetek małych dzieci (do lat 5) uczęszczających do żłobków i przedszkoli (Szukalski, Warzywoda-Kruszyńska: 2005: 112-114; Kotowska, Giza-Poleszczuk 2010: 56). Niedorozwój „infrastruktury opiekuńczo-wychowawczej dla małych dzieci" jest w dużej mierze konsekwencją decentralizacji polityki rodzinnej i obciążenia samorządów kosztami jej utrzymania - wobec ograniczonych możliwości organizacyjnych i finansowych duża część placówek została zlikwidowana lub ograniczono ich dostępność przez podwyższenie opłat za usługi (Balcerzak-Paradowska 2004b: 253). Co ciekawe, problem ten często pozostaje niezauważony przez rodziców małych dzieci, którzy oddają potomstwo pod opiekę dziadków (Szukalski, Warzywoda-Kruszyńska 2005: 111). Badacze zwracają uwagę na niewielkie zainteresowanie zinstytucjonalizowanymi formami opieki nad małymi dziećmi, co wyjaśniać można m.in. stosunkowo wysokimi kosztami tych usług (w porównaniu z korzystaniem z ,darmowej” pomocy dziadków lub innych krewnych), dość powszechnym przekonaniem o wyższości opieki matki czy babci nad opieką instytucjonalną (Matysiak 2007: 402), wreszcie „ten stan rzeczy może wynikać z faktu, że brak przedszkoli traktowany jest jako fakt zastany, na który jednostki nie mają wpływu i dlatego poszukują innych, dostępnych im rozwiązań (pomoc babek)" (Szukalski, Warzywoda-Kruszyńska 2005: 115). Z drugiej jednak strony wyniki badań przeprowadzonych 
wśród kobiet deklarujących, że nie chcą mieć (kolejnego) dziecka lub wahają się w kwestii powiększenia rodziny, pokazują, że lepiej dostępne i oferujące usługi lepszej jakości żłobki, przedszkola oraz szkolne świetlice mogą być istotnym czynnikiem wpływającym na decyzje prokreacyjne (Matysiak 2007b: 433, 434). Niezbędne jest tworzenie innych, alternatywnych do żłobków, form opieki nad dziećmi w wieku do 3 lat. Ustawa o formach opieki nad dziećmi w wieku do lat 3 (z dn. 4 lutego 2011 r.) poza żłobkami, oferującymi całodzienną opiekę nad dzieckiem, wprowadza także kluby dziecięce, w których dzieci przebywają krócej (do 5 godzin dziennie), instytucję opiekuna dziennego oraz reguluje i ułatwia zatrudnienie niani. Wydaje się, że przepisy te, wzbogacające i urozmaicające ofertę instytucjonalnej opieki nad małymi dziećmi, wychodzą naprzeciw potrzebom pracujących rodziców. Istotną przeszkodą w tworzeniu nowych form opieki nad dziećmi jest jednak obciążenie, zarówno organizacyjne jak i finansowe, tymi zadaniami gminnych samorządów, których możliwości są ograniczone.

Jak stwierdza Steven Saxonberg, ,każda polityka rodzinna, która poważnie traktuje prawa jednostki, musi uwzględniać prawo ludzi do wyboru ich własnego stylu życia” (Saxonberg 2010: 98). Oznacza to poszanowanie ,prawa kobiet do kontynuowania kariery zawodowej, nawet gdy mają one dzieci" lub inaczej: poszanowanie ,prawa kobiet do posiadania dzieci, nawet wtedy gdy chcą one robić kariery zawodowe" (tamże). Biorąc pod uwagę równość płci powinno się ten postulat odnieść także do mężczyzn i umożliwiać im pełne zaangażowanie w życie rodzinne. Jednak jak zauważa cytowany autor analizujący politykę rodzinną w krajach postkomunistycznych, w tym w Polsce, ich celem explicite lub implicite jest zatrzymanie matek $\mathrm{w}$ domu, a tym samym utrzymywanie tradycyjnego podziału ról (tamże: 101). W przypadku Polski mamy do czynienia z pozornym zorientowaniem na aktywizację zawodową kobiet (np. możliwość dzielenia urlopu macierzyńskiego i rodzicielskiego pomiędzy oboje rodziców, bezpłatny urlop wychowawczy zniechęcający do korzystania z niego), a w rzeczywistości z niejawnym oczekiwaniem (i w wielu przypadkach niepozostawieniem wyboru), by matka w pierwszych latach życia zajmowała się potomstwem, czego dowodzi chociażby niski dostęp do instytucjonalnej opieki nad dziećmi (Saxonberg 2010: 103-104). Brakuje zachęt dla ojców, by to oni zostali w domu z potomstwem. Jak pokazuje przypadek Węgier, płatne urlopy wychowawcze przy kwocie zasiłku uzależnionej od pobieranego wynagrodzenia zachęcają mężczyzn do korzystania $\mathrm{z}$ tego uprawnienia (tamże: 105).

Podsumowując, polityka rodzinna w Polsce uwzględnia model rodziny z dwojgiem pracujących rodziców, zawiera rozwiązania sprzyjające łączeniu pracy zawodowej z obowiązkami rodzinnymi, dotyczące nie tylko matek, ale także ojców. Instrumenty te jednak często nie są satysfakcjonujące dla pracujących rodziców (liczba dostępnych placówek opiekuńczych, wysokość świadczeń rodzinnych) oraz dla pracodawców (koszty związane z respektowaniem uprawnień pracowniczych przysługujących rodzicom małych dzieci). W rezultacie konser- 
wują tradycyjny podział ról w rodzinie, zgodnie z którym to kobiety są obciążone obowiązkami rodzinnymi. Zdaniem Ireny Kotowskiej i Anny Gizy-Poleszczuk, „mamy do czynienia z nienadążaniem «praktyki» codziennego życia za «teorią»: ideami i rozwiązaniami przejętymi $\mathrm{w}$ przyspieszonym tempie $\mathrm{z}$ bardziej rozwiniętych krajów”, które „natrafiają na opory kulturowe i społeczne” (2010: 61). Jak pokazują wyniki badań (omawiane w podrozdziale 4.3), polskie społeczeństwo jest w dużej mierze konserwatywne i tradycyjne, jeżeli chodzi o role kobiece i męskie, w tym role rodzicielskie. Mamy tu zatem do czynienia z sytuacją, o której pisał U. Beck - próbą dokonywania zmian ,powierzchniowych”, które nie mogą przynieść trwałych skutków, jeśli nie będą im towarzyszyć zmiany generalne: instytucjonalne (organizacji i wymogów rynku pracy) oraz kulturowe, zachodzące równolegle.

\subsection{Kobiecość, męskość, macierzyństwo i ojcostwo w katolickiej nauce społecznej ${ }^{5}$}

Ronald Inglehart i Pippa Norris, analizując różne czynniki mające wpływ na równouprawnienie płci w społeczeństwach całego świata, wskazują m.in. na znaczenie religii (2009). Na podstawie międzykulturowych badań stwierdzają, że wraz ze słabnięciem wartości religijnych i postępującą sekularyzacją następuje liberalizacja postaw i przekonań dotyczących podziału ról płciowych (tamże: 62). Polskie społeczeństwo należy do bardzo religijnych w porównaniu z innymi kulturami (tamże: 68). Wyniki badań pokazują, że 95\% Polaków uznaje się za katolików, ponad połowa (54\%) regularnie (przynajmniej raz w tygodniu) uczestniczy w praktykach religijnych (CBOS 2009b). Miarą znaczenia religii w życiu społecznym jest jednak nie tylko liczba osób wierzących i praktykujących, ale także rola Kościoła jako aktora w życiu publicznym, wpływającego na decyzje polityczne, która w Polsce jest zauważalna (Środa 2007). Dostrzec ją można szczególnie w publicznej debacie dotyczącej rodziny, seksualności i prokreacji, w której przedstawiciele Kościoła bronią tradycyjnych wartości i blokują możliwość zmian. Narzędziem wpływu na jednostki poza zabieraniem głosu w publicznych sprawach, religijnymi praktykami, w których uczestnictwo ma charakter dobrowolny, są także lekcje religii w szkołach (dobrowolność udziału w nich jest tylko pozorna, ze względu na częsty brak alternatywy dla uczniów oraz konformizm grupowy wśród dzieci i młodzieży). W Polsce uczniowie mają w szkole 2 godziny

${ }^{5}$ Katolicka nauka społeczna obejmuje ,usystematyzowany w doktrynalną, logicznie i funkcjonalnie spójną całość zbiór teoretycznych tez i praktycznych dyrektyw, wypracowanych w ciągu ostatnich dwu wieków przez katolickich filozofów, teologów, moralistów, ekonomistów i socjologów, a odnoszących się do rozwiązania palących społeczno-gospodarczych zagadnień współczesności, a nawet ustawicznej reformy całego porządku społecznego". Jest zgodna z teologiczną nauką Kościoła (Katolicyzm A-Z, 1982: 200-201, za: Kaniewski 2009: 172). 
religii tygodniowo przez 12 lat nauki (Środa 2007: 654). Silna pozycja Kościoła w polskim społeczeństwie jest uzasadniana jego rolą w historii jako „fundamentu polskiej tradycji" i źródła kolektywnej tożsamości w czasach utraty państwowości (tamże: 655). To nakładanie się wspólnotowości religijnej i narodowej wzmacnia i legitymizuje obecność instytucji Kościoła w sferze publicznej i nadaje jej wysoki status społeczny, niespotykany w innych krajach katolickich (tamże). Nie bez znaczenia jest także zjawisko ,papolatrii, czyli egzaltowanego kultu papieża” Jana Pawła II w Polsce (Szostkiewicz 2002, za: Arcimowicz 2003: 146).

Mimo różnych możliwości kształtowania świadomości i postaw jednostek przez Kościół katolicki w Polsce, religijność Polaków zmienia się (dotyczy to religijności w ogóle, nie tylko polskiego katolicyzmu). Wiara ma coraz bardziej prywatny i zindywidualizowany charakter, także w niej znajduje wyraz (po)nowoczesna idea „zrób-to-sam” dotycząca jednostkowych biografii i tożsamości (Załęcki 2003: 105; Frąckowiak-Sochańska 2009: 64). Przejawia się to „zarówno w selektywności wierzeń religijnych w stosunku do obowiązujących dogmatów kościelnych, jak i w ich współwystępowaniu z wierzeniami stanowiącymi element innych niż chrześcijański systemów religijnych" (Frąckowiak-Sochańska 2009: 64). Wyniki badań pokazują, że coraz mniej osób dostrzega wpływ zasad religijnych na swoje ,poglądy na świat i życie” (55\% w 2010 r., 73\% wskazywało na rolę Jana Pawła II) (CBOS 2010: 1-2). Główną rolę, zdaniem badanych, w kształtowaniu ich światopoglądu odgrywają własne przemyślenia oraz rodzice (wskazania odpowiednio 83\% i 80\%). Określając swoją wiarę, ponad połowa uczestników sondażu $(56,7 \%)$ zadeklarowała, że jest wierząca i stosuje się do wskazań Kościoła, a 39,6\% respondentów określiło się jako „wierzących na swój własny sposób" (CBOS 2010: 4). Wyniki te pokazują z jednej strony, że procesy indywidualizacji i wzrost podmiotowości jednostek znajdują także wyraz w zmianie religijności i postaw wobec kościoła, z drugiej jednak świadczą o wciąż silnym wpływie religii na przekonania i postawy Polaków.

Rolą religii jest dostarczanie jednostkom wartości i norm, kategorii postrzegania świata i ludzi, w tym siebie samych. Tu interesuje nas sposób definiowania przez Kościół katolicki kobiecości i męskości, macierzyństwa i ojcostwa oraz oczekiwania związane z tymi rolami, nakładane na jednostkę. W celu ich rekonstrukcji odwołano się do opracowań analizujących Pismo Święte oraz Katechizm Kościoła Katolickiego, a także nauczanie Jana Pawła II oraz tekstów mieszczących się w nurcie katolickiej nauki społecznej, poświęconych rolom płciowym i rodzicielskim (m.in. zebranych w książkach pod red. Doroty Kornas-Bieli Oblicza macierzyństwa - 1999 i Oblicza ojcostwa - 2001 oraz Macierzyństwo i Ojcostwo z 1998 roku pod red. Józefa Augustyna SI).

$\mathrm{Na}$ gruncie katolicyzmu mamy do czynienia z naturalistycznym, esencjalistycznym ujęciem płci człowieka, która jest traktowana jako coś naturalnego, danego przez Boga - nie stworzonego przez ludzi czy kulturę - a zatem niepodważalnego i niezmiennego (Szwed 2009: 76). Płeć determinuje przeznaczenie 
jednostki, której nie pozostawia się wyboru drogi życiowej poza przewidywanymi opcjami. Na przykład w przypadku kobiet mówi się o dwóch powołaniach: macierzyństwie oraz dziewictwie, uosabianych przez Maryję (Wojtecki 2009: 50; Ozorowski 2009: 14, 17). A zatem kobieta ma wybór pomiędzy rodziną a służbą Bogu lub innym ludziom, podobnie jak mężczyzna, który wybiera między „ojcostwem naturalnym” czy „fizycznym” w rodzinie i „ojcostwem duchowym”, przeżywanym w celibacie (Augustyn 1998a: 13, 1998b: 20). Podkreśla się odmienność cech i ról kobiet i mężczyzn, częściej jednak mówi się o „specyfice kobiecej natury", co wskazuje na traktowanie tego co męskie jako normy, pierwowzoru. Znajduje to uzasadnienie w opisanym w Biblii akcie stworzenia kobiety z żebra mężczyzny, który jednak interpretuje się na gruncie katolickiej nauki społecznej nie jako pierwszeństwo męskości przed kobiecością, ale jako „równość natury obu płci” przy jednoczesnej odmienności cech i ról do spełnienia: „Kobieta jest dopełnieniem mężczyzny, tak jak mężczyzna jest dopełnieniem kobiety: kobieta i mężczyzna są komplementarni. Kobiecość realizuje "człowieczeństwo» w takim samym stopniu jak męskość, choć w sposób odmienny i komplementarny" (Jan Paweł II 1995, za: Szwed 2009: 77). W innej wypowiedzi papieża można jednak znaleźć sformułowanie: „Kobieta zostaje stworzona przez Boga «z żebra» mężczyzny i zostaje postawiona jako drugie «ja» [...]. Niewiasta jest drugim «ja» we wspólnym człowieczeństwie" (Jan Paweł II 1996, za: Arcimowicz 2003: 154). Słowa te można interpretować jako przekonanie o drugorzędności kobiety: „Być pierwszym w kolejności stwarzania oznacza stać wyżej i mieć przewagę nad istotą, która pojawiła się później (Arcimowicz 2003: 154; Adamiak 1999: 36).

Katolicka wizja kobiecości i męskości definiuje je jako dane z góry, ,równe lecz różne". Wizerunek męskości propagowany na gruncie katolicyzmu przedstawia mężczyznę zdyscyplinowanego, odważnego, odpowiedzialnego, przezwyciężającego własne słabości, dążącego do doskonałości przez naśladowanie Chrystusa - ideału człowieczeństwa i męskości (Arcimowicz 2003: 157). Wspominaną specyfiką kobiet - ,geniuszem” kobiet, jak określił to Jan Paweł II - jest ich emocjonalność, troska o relacje z innymi oraz „wspólnototwórcza” rola (Ozorowski 2009: 13, 14; Zabielski 2009: 31). Ich jedyna w swoim rodzaju miłość („,nikt nie potrafi tak kochać jak kobieta”) jest „konieczna mężczyźnie, dziecku, społeczeństwu” (Ozorowski 2009: 13). „Naturalne” pokłady opiekuńczości i troski u kobiet, związane z macierzyństwem, uzasadniają feminizację zawodów wymagających takich predyspozycji: „To w kobietach rodzi się i rozwija nowe życie. Nic więc dziwnego, że kobiety zostały obdarzone funkcją otwartości i gotowości do zajmowania się innymi ludźmi i dotąd najlepiej spełniają się w takich zawodach jak: pielęgniarka, opiekunka i nauczycielka" (Kudrycka, Kopeć 2009: 26).

W Księdze Rodzaju zdefiniowany zostaje podział ról płciowych: gdy do kobiety należy rodzenie dzieci, do mężczyzny zapewnienie bytu rodzinie, co uprawomocnia jego pozadomową aktywność (,W pocie więc oblicza twego będziesz musiał zdobywać pożywienie" - Rdz 3, 19, za: Arcimowicz 2003: 161). Propagując 
tę tradycyjną „,specjalizację płciową”, zgodnie z którą mężczyzna pracuje zawodowo, a kobieta zajmuje się domem, nie wymaga się ograniczenia się przez kobiety do ról rodzinnych, jednak role te traktuje się jako pierwszoplanowe: „Praca zawodowa kobiety oraz każda forma jej zaangażowania poza domem musi być zgodna z najważniejszym powołaniem kobiety jako żony i matki" (Jan Paweł II 1994, za: Kornas-Biela 1998: 75). Przeznaczenie mężczyzny widzi się w sprawowaniu władzy, co przejawia się na przykłąd w niedopuszczaniu kobiet do najwyższych urzędów w Kościele. Przypisuje mu się także funkcję głowy rodziny, co rozumiane jest m.in. jako odpowiedzialność za podejmowanie decyzji. Mężczyznę do sprawowania władzy w rodzinie predestynują następujące cechy: racjonalność przy podejmowaniu decyzji, „dystans emocjonalny” (wynikający z funkcjonowania na zewnątrz rodziny), obiektywność i odporność psychiczna, większa siła fizyczna (pozwalająca mu stanąc w obronie rodziny), konsekwencja, wreszcie potrzeba władzy (lepiej niż kobieta „się w tej roli czuje, jest w swoim żywiole”, dzięki posiadanej władzy mężczyzna się rozwija) (Pulikowski 2010: 125-128).

Za podkreślaniem różnicy między kobiecością i męskością idzie odmienne definiowanie roli matki i ojca. Chociaż w Katechizmie Kościoła Katolickiego czytamy, że oboje rodzice są odpowiedzialni za wychowanie dzieci, kształtowanie cnót, dawanie dobrego przykładu (KKK 2223), to zacytowane tu zostają następujące fragmenty z Biblii: „Kto miłuje swego syna, często używa na niego rózgi, aby na końcu mógł się nim cieszyć (Syr 30,1-2)”; „A wy, ojcowie, nie pobudzajcie do gniewu waszych dzieci, lecz wychowujcie je, stosując karcenie i napominanie Pańskie! (Ef 6, 4)" (za: Arcimowicz 2003: 161). Także w innych „przepisach” Katechizmu, poświęconych posłuszeństwu dzieci, wskazuje się, że to ojciec ma być surowym wychowawcą, gdy trzeba stosującym kary fizyczne. Jak stwierdza Krzysztof Jedliński, ,[...] dyscyplinowanie to funkcja tradycyjnie ojcowska. [...] kojarzy się ze sprawiedliwością, konsekwencją i stanowczością" (Jedliński 1998: 116). Odrzuca się tu jednak stereotyp twardego, oschłego, „oziębłego emocjonalnie", thumiącego uczucia mężczyzny, pozwalając mu na okazywanie emocji i wzruszenia, wyzwalanych w kontakcie z dzieckiem (Kociołek 1998: 121, 127). Takie połączenie w ojcostwie pozornie sprzecznych ze sobą zachowań, jak surowość i miłość, występuje w figurze Boga będącego wzorem dla mężczyzny (Mierzwiński 1999: 90; Kornas-Biela 2001: 190). „Bóg-Ojciec uczy mężczyznę, jak postępować wobec dzieci w bardzo praktycznym wymiarze. Cała historia zbawienia pełna jest obrazów Ojca pałającego słusznym gniewem, surowego, karcącego, domagającego się zadośćuczynienia, ale i cierpliwego, po wielokroć przebaczającego, czułego, tulącego do policzka i ponad wszystko miłującego" (Kociołek 1998: 126). Tak jak wzorem ojcostwa ma być dla mężczyzny Bóg-Ojciec, tak kobiety mają wzorować się na Maryi: „To Ona jest wielkim pierwowzorem powołania każdej kobiety. [...] Maryja przez przykład swojego życia przypomina każdej kobiecie, że do rozwoju jej osobowości potrzebna jest miłość, że jedynie przez uczynienie $\mathrm{z}$ siebie daru dla drugich i przedkładanie ich potrzeb 
nad własne, może kobieta zrealizować plan Boga we własnym życiu" (Jan Paweł II 1994, za: Kornas-Biela 1998: 68, 69).

U podstaw katolickich definicji macierzyństwa i ojcostwa leży polaryzacja płci: kobieta (i matka) jest emocjonalna, wrażliwa, bliższa domu i natury, to strażniczka domowego ogniska, „serce wspólnoty rodzinnej” (Jan Paweł II, za: Kornas-Biela 1998: 69). Mężczyzna (i ojciec) natomiast jest racjonalny, zrównoważony emocjonalnie, bliższy kulturze, funkcjonujący głównie w zewnętrznym, pozadomowym świecie, to głowa rodziny, zapewniająca jej byt i bezpieczeństwo. O szeroko rozumianej słabości kobiet świadczą takie męskie funkcje, jak „bycie stabilnym oparciem" dla partnerki oraz dzieci, obrońcą rodziny przez różnymi niebezpieczeństwami (także moralnymi), a także swego rodzaju „stróżem” kobiety: mężczyzna „ma strzec matki swych dzieci, żony swojej, żeby się nie pogubiła [...] w swoich uczuciach, emocjach i rozlicznych drobiazgach" (Pulikowski 2010). Mamy tu funkcjonalny, Parsonsowski podział zadań na ekspresyjne-kobiece i instrumentalne-męskie i w związku z tym inne kryteria oceny i samooceny przedstawicieli obu płci. Kobieta jest stworzona do tego, by „szerzyć miłość na świecie” (tamże: 35, 62). Istotą życia mężczyzny jest z kolei „,przeobrażanie świata" - jego rozumienie, analizowanie przyczyn i skutków zjawisk i dokonywanie zmian (tamże: 36). Można by powiedzieć, parafrazując słowa Adama Mickiewicza: kobiecość to „czucie i wiara”, męskość - „mędrca szkiełko i oko”. W katolickim opisie ról rodzicielskich znaleźć można niemal bezpośrednie odwołania do charakterystyki roli matki i ojca E. Fromma (patrz podroz. 2.3). „Żona - matka chroni ognisko rodzinne i jest w naturalny sposób skierowana do wewnątrz, niejako otula sobą nowe życie rodzące się w rodzinie. Ojciec walczy na zewnątrz, pokonując niesprzyjające warunki, zapewniając rodzinie niezbędny pokój i warunki materialne do rozwoju" (Kociołek 1998: 121). Mimo podkreślania równoważności ról obojga rodziców, można odnieść wrażenie, że choć to matka jest tą, która daje życie i której nie da się zastąpić, to jednak ojcowskie zadania są donioślejsze - to w ich efekcie dziecko staje się samodzielną, dojrzałą osobą. Gdyby odnieść się do piramidy potrzeb Abrahama Maslowa, matka odpowiada za zaspokojenie potrzeb podstawowych, ojciec zaś - wyższych: „Matka z początku rodzi dziecko przede wszystkim do życia biologicznego i uczuciowego. Ojciec jest wezwany do podjęcia tego procesu i «współrodzenia» dziecka do życia duchowego, religijnego, intelektualnego, do dojrzałości emocjonalnej” (Kociołek 1998: 144). 144). Inny stosunek matki i ojca do dziecka jest wyjaśniany ich naturalnymi cechami i predyspozycjami (emocjonalność versus racjonalność) oraz „fizycznym” doświadczeniem macierzyństwa (ciąża, poród, karmienie piersią), niedotyczącym mężczyzn: „Matka spontanicznie poświęca się dla swojego dziecka. Czyni to najczęściej o wiele «łatwiej» i «chętniej» niż ojciec, który z reguły reaguje na swoje dzieci bardziej «racjonalnie» i «spokojnie». [...] Ojcowie «przekonują» się do swoich dzieci nieraz dopiero w miarę ich wzrastania i rozwoju. Radością ojców jest przede wszystkim wprowadzać własne dzieci w szeroki świat i uczyć «sztuki 
życia» w świecie" (Augustyn 1998b: 18). W przywoływanych przez Katechizm Kościoła Katolickiego biblijnych fragmentach znajdujemy potwierdzenie różnicy między miłością matki i ojca, wyrażające się w postulowanej innej postawie dziecka wobec każdego z rodziców: „Z całego serca czcij swego ojca, a boleści rodzicielki nie zapominaj! (Syr 7, 27-28)”; „Kto czci ojca, zyskuje odpuszczenie grzechów, a kto szanuje matkę, jakby skarby gromadził (Syr 3, 2-6)" (KKK 2215, 2218, za: Arcimowicz 2003: 162). Można odnieść wrażenie, że oddawana ojcu cześć (i ,jedynie" szacunek dla matki i pamięć o jej cierpieniu przy porodzie) podnosi jego rangę w rodzinie, czyni go ważniejszym - niemal „Bogiem na ziemi” (Delumeau, Roche 1995: 11). Podczas gdy matkę, za Janem Pawłem II, można określić mianem „kapłanki «Kościoła domowego» (Kornas-Biela 1998: 69).

Katolickie definicje kobiecości i męskości, macierzyństwa i ojcostwa mieszczą się w tradycyjnym modelu płci. Pociąga to za sobą krytykę tego, co „nowoczesne” i podważające „boski” podział ról. Znajdujemy tu krytyczne podejście do partnerstwa, które jest traktowane jako zacierające naturalne różnice między kobietą i mężczyzną, matką i ojcem (Pulikowski 2010). Jak ujmuje to Dorota Kornas-Biela, w ramach nowoczesnego modelu płci i rodzicielstwa mamy do czynienia $\mathrm{z}$,bezpłciowym rodzicem, rodzicem androgenicznym, ojcem matkującym dziecku wraz z matką ojcującą dziecku" (Kornas-Biela 2001: 177). Wiele miejsca poświęca się kryzysowi ojcostwa, zauważając „degradację” mężczyzny w rodzinie i rezygnację ze specyfiki ojcostwa: „Ojciec zdegradowany w rodzinie z pozycji autorytetu traktowany jest najczęściej jako «przydatna ciocia» lub «druga mama» pomagająca matce spełniać jej funkcje pielęgnacyjno-wychowawcze wobec dziecka” (Kornas-Biela 2001: 176). „Nowoczesne ojcostwo” jest tu rozumiane jako sztuczne i narzucone upodobnienie go do macierzyństwa, co powoduje u mężczyzny psychiczny dyskomfort, niepewność, niepokój: „Niezręcznie czuje się jako «mama w portkach»" (tamże: 177). Jako jedną z przyczyn kryzysu męskości i ojcostwa wskazuje się emancypacyjny ruch kobiet, który ,[...] zaatakował dominującą rolę mężczyzny i szereg tradycyjnie spełnianych przez niego funkcji. Wywołał kompleks winy u mężczyzny i poczucie zagubienia we współczesnym świecie" (Mierzwiński 1999: 73). Feminizm oceniany jest jako „niebezpieczny”, ,absurdalny”, ,sprzeczny z naturą i zdrowym rozsądkiem”, ,deformujący pojmowanie natury kobiety oraz jej tożsamości w życiu indywidualnym i społecznym" (Zabielski 2009: 41), „oparty na zniekształconej wizji wolności” (Wojtecki 2009: 48).

$\mathrm{Z}$ drugiej strony można $\mathrm{w}$ katolickim podejściu do ról płciowych i rodzicielskich odnaleźć pewne elementy nowoczesnego modelu. Propaguje się tu ideę równości w różnicy, dostrzega problem istnienia nierówności płci i niesprawiedliwego, gorszego położenia społecznego kobiet, postuluje uznanie ich ,geniuszu” i docenienie ich roli w społeczeństwie. To „nowoczesne” podejście do problematyki płci zainicjował Jan Paweł II apostolskim Listem do kobiet (1995) (Wojtecki 2009; Środa 2007: 661; Kaniewski 2009: 175). Papież podkreślał znaczenie kobiecych wartości dla społecznego rozwoju, uznając je za niezbędne do stworzenia „cywili- 
zacji miłości” - „bardziej ludzkiego świata”, opartego na „miłości, prawdzie, wolności, sprawiedliwości i solidarności” (Kudrycka, Kopeć 2009: 26). Zaproponował „,nowy feminizm”, który ,ze starym feminizmem dzieli sprzeciw wobec dyskryminacji i wyzysku kobiety”, ,walczy o równouprawnienie, ale nie wyrzeka się powołania do macierzyństwa" (Wojtecki 2009: 53). Podkreśla się w nim biologiczne różnice między kobietami i mężczyznami, ale nierówności płci traktuje jako wytwór kultury (Bóg stwarza kobietę i mężczyznę równymi), a zatem podlegający zmianie. Jak jednak zauważa Anna Szwed, ,[...] z prądem myślowym czy ruchem społecznym, jakim jest feminizm, propozycję Jana Pawła II wiąże chyba tylko ten termin. Oswojone słowo «feminizm» opiera się w wydaniu papieskim nie na «nowej», ale na tradycyjnie rozumianej roli kobiety - znaczonej «darem z siebie», wrażliwością na bliźniego i macierzyństwem" (Szwed 2009: 85). Brak tu konkretnych wskazówek jak przeciwdziałać dyskryminacji kobiet i osiągnąć „,równość w różnicy”. Dowartościowanie kobiet ma charakter symboliczny. Zwraca na to uwagę Magdalena Środa, pisząc o kulcie maryjnym w Polsce i związanym z nim ,szczególnym szacunku do kobiet", przejawiającym się w przepuszczaniu w drzwiach, całowaniu w rękę, ustępowaniu miejsca itp. (Środa 2007: 661). Jak podkreśla autorka, to „etykietalne uprzywilejowanie kobiet nie ma żadnego odzwierciedlenia w realnej sytuacji politycznej, społecznej czy ekonomicznej” (tamże).

Androcentryzm i patriarchalny charakter katolicyzmu znajduje wyraz w sposobie mówienia o kobietach i mężczyznach nie tylko w Piśmie Świętym, ale także Katechizmie Kościoła Katolickiego czy papieskich dokumentach. Po pierwsze, męskość wymieniana jest na pierwszym miejscu: mężczyzna przed kobietą, ojciec przed matką, syn przed córką, bracia przed siostrami, Adam przed Ewą itp. (Arcimowicz 2003: 149). Po drugie, dla określenia obu płci stosuje się rzeczowniki rodzaju męskiego, a zatem mówi się o synach, braciach, uczniach (tamże). Po trzecie, mówi się o kobiecości w relacji do męskości (męskość jako punkt odniesienia, porównania), nigdy odwrotnie (Szwed 2009: 77): „O ile stosunkowo łatwo znaleźć jest sformułowanie typu: «godność kobiety jest równa godności mężczyzny», [...], o tyle dużo trudniej, o ile jest to w ogóle możliwe, natrafić na przekaz odwrotny, np. "godność mężczyzny jest równa godności kobiety». Skłania to do hipotezy, że kobiety w nauczaniu Kościoła są w dużym stopniu traktowane jako «inny», a co z tego wynika - normatywność wydaje się być silniej kojarzona z męskością niż z kobiecością" (tamże). Ponadto, zapoczątkowane Listem do kobiet papieża Jana Pawła II (1995) podkreślanie wartości tego co kobiece i roli kobiet w społeczeństwie jest pośrednim dowodem na wcześniejsze ich niedowartościowanie i przyzwalanie na gorszy status społeczny kobiet oraz świadczy o konieczności przekonywania o równości płci (Środa 2007: 661). Jak stwierdza Elżbieta Adamiak, odnosząc się do wspominanego Listu do kobiet i zawartych w nich wyrazów wdzięczności wobec „płci pięknej”, ,samo wypowiadanie takich słów - stanowiących jakąś próbę przezwyciężenia - wskazuje na ciągle istniejącą nierównowagę i niesprawiedliwość" (Adamiak 1999: 36). 
Podsumowując, w religii katolickiej sankcjonowany jest tradycyjny podział ról płciowych i rodzicielskich, traktowany jako naturalny i najlepszy z możliwych, bo stworzony przez Boga. Mimo podkreślania równości kobiet i mężczyzn, matek i ojców, Kościół katolicki, podtrzymując patriarchalny porządek społeczny, utrwala i legitymizuje tym samym wpisane weń nierówności płci. Ze względu na ważne miejsce w życiu publicznym i politycznym w Polsce ma on realny wpływ na blokowanie zmian ukierunkowanych, bezpośrednio lub pośrednio, na wyrównywanie statusu społecznego kobiet i mężczyzn, postrzegane przez jego przedstawicieli jako zagrożenie dla „,naturalnej” różnicy płci. Zdaniem Magdaleny Środy, Kościół w Polsce ,jest głównym hamulcowym na drodze emancypacji kobiet" (Środa 2007: 654). Z drugiej jednak strony, analiza religijności Polaków i ich stosunku do instytucji Kościoła oraz zachowań niezgodnych z jego regułami pokazuje, że w prywatnym życiu wielu z nich kwestionuje katolicką wizję rodziny, seksualności oraz ról płciowych i rodzicielskich. Odwołując się do koncepcji A. Kłoskowskiej, katolicki model płci i rodzicielstwa można określić jako model oficjalny, propagandowy, który nie musi odpowiadać modelom środowiskowym i rzeczywistym wzorom zachowań.

\subsection{Modele i wzory macierzyństwa i ojcostwa w Polsce w świetle wyników badań społecznych}

W niniejszym podrozdziale podjęta zostanie próba rekonstrukcji modeli i wzorów kobiecości i męskości oraz macierzyństwa i ojcostwa funkcjonujących w polskim społeczeństwie, na podstawie wyników badań społecznych. W analizie modeli wykorzystano wyniki badań opinii publicznej na temat „właściwych” kobietom i mężczyznom ról w społeczeństwie, dzięki czemu poznajemy normy, uznane społeczne powinności odnoszące się do ról płciowych i rodzicielskich. W celu odtworzenia dominujących wzorów tych ról posłużono się wynikami badań rzeczywistych doświadczeń i zachowań kobiet i mężczyzn, matek i ojców (zakładając, że deklaracje co do zachowań odpowiadają zachowaniom w rzeczywistości $)^{6}$. W obu przypadkach były to badania przeprowadzone na ogólnopolskich reprezentatywnych próbach.

${ }^{6}$ Według A. Kłoskowskiej, badania ankietowe dotyczą nie wzorów, a modeli społecznych: „Badania typu ankietowego [...] nadające się do masowych ilościowych opracowań nie są w stanie zastąpić metod obserwacji jako źródła poznania obyczajów, trwałych i faktycznych form ludzkiego zachowania w różnych dziedzinach. [...] Odpowiedzi uzyskane przez ankietera mogą różnić się bardzo znacznie nie tylko od faktycznych zachowań, których dotyczą, ale także od opinii wygłaszanych w odmiennej sytuacji: w gronie «swoich», pośród rodziny, sąsiadów, przyjaciół” (Kłoskowska 1960: 118). Wywiad bowiem „ma charakter sytuacji oficjalnej, zbliżonej do sytuacji publicznego przemówienia albo prasowego lub radiowego wywiadu" (tamże). 


\subsubsection{Modele kobiecości i męskości, macierzyństwa i ojcostwa}

Socjologiczne badania postaw wobec ról kobiet i mężczyzn w społeczeństwie polegają najczęściej, jak podaje Henryk Domański, na postawieniu respondenta wobec alternatywy, co dla kobiety powinno być ważniejsze: dom i rodzina czy praca (Domański 1995: 66). W zależności od tego, ku której wartości badany się skłania, interpretuje się jego poglądy jako mniej lub bardziej tradycyjne lub nowoczesne.

Na początek odwołamy się do wyników badań sondażowych CBOS dotyczących preferowanego modelu rodziny, według których blisko połowa Polaków (46\%) - 50\% kobiet i 43\% mężczyzn, opowiedziała się za modelem partnerskim, opierającym się na porównywalnym zaangażowaniu obojga małżonków (partnerów) w sprawy rodzinne i zawodowe (CBOS 2013a: 13). Model tradycyjny, w którym jedynie mężczyzna pracuje, zarabiając wystarczająco na zaspokojenie potrzeb rodziny, natomiast kobieta zajmuje się prowadzeniem domu i dziećmi był preferowany przez $23 \%$ respondentów (19\% kobiet i $26 \%$ mężczyzn), podobnie jak model określany przez badaczy jako „nieproporcjonalny żeński”, w którym pracują oboje partnerzy, jednak mężczyzna bardziej angażuje się w pracę, a kobieta bardziej poświęca się rodzinie (22\% ogółu badanych; 23\% kobiet i 20\% mężczyzn) (tamże). Pozostałe możliwości, tj. rodzina z odwróconymi rolami (kobieta i mężczyzna pracują, ale to na kobiecie spoczywa główny ciężar utrzymania rodziny, podczas gdy mężczyźnie przypadają w udziale obowiązki domowe) oraz „model odwrócony”, w którym kobieta jest jedynym żywicielem rodziny, a mężczyzna prowadzi dom, miały nielicznych zwolenników (odpowiednio 6\% i 1\%).

O unowocześnianiu się podejścia Polaków do ról płciowych oraz rodzicielskich mogłyby świadczyć także inne dane. W badaniu przeprowadzonym na potrzeby projektu „Aktywność zawodowa i edukacyjna a obowiązki rodzinne” (2005) na dużej reprezentatywnej próbie, respondenci ustosunkowywali się do kilku stwierdzeń dotyczących podziału ról kobiet i mężczyzn (Baranowska 2007: 405-406). Większość badanych $(78,1 \%$ kobiet oraz $65,3 \%$ mężczyzn) wyraziła przekonanie, że oboje partnerzy powinni w równym stopniu dzielić się obowiązkami zawodowymi i rodzinnymi, co mogłoby dowodzić upowszechnienia nowoczesnego modelu. Jednak w tym samym badaniu ponad połowa kobiet i mężczyzn (odpowiednio 53,6\% i $62,4 \%$ ) opowiedziała się za tradycyjnym modelem rodziny, uznając, że mężczyzna powinien zajmować się zarabianiem pieniędzy, a kobieta powinna troszczyć się o dom i rodzinę. Znaczna część respondentów (48,7\% i 42,5\%) odrzuciła sytuację „odwrócenia" ról, w której to kobieta pracuje, a mężczyzna zajmuje się domem i dziećmi. Badani oczekują, że role rodzinne będą dla kobiet pierwszoplanowe i zrezygnują one z pracy zawodowej lub ograniczą jej wymiar na rzecz aktywności w sferze prywatnej. W odniesieniu do mężczyzn to role zawodowe są traktowane jako priorytetowe (sytuację pracy ojca w niepełnym wymiarze, by godzić ją z obowiązkami rodzinnymi negatywnie oceniło $57,9 \%$ mężczyzn i 57,1\% kobiet). 
Wyniki Europejskiego Sondażu Społecznego 2004 pokazują, że duża część polskiego społeczeństwa jest przekonana nie tylko o powinności utrzymywania rodziny przez mężczyzn, ale także o tym, że mężczyźni mają większe prawo do pracy zawodowej niż kobiety - 42\% mężczyzn w wieku $18-65$ lat i 35\% zamężnych kobiet zgodziło się ze stwierdzeniem, że „kiedy sytuacja na rynku pracy jest trudna, mężczyźni powinni mieć pierwszeństwo w uzyskaniu pracy przed kobietami" (co pokazuje, że należymy do najbardziej konserwatywnych europejskich społeczeństw) (Titkow, Duch-Krzystoszek 2009: 38).

Wysoka ocena partnerskiego modelu rodziny przy jednoczesnym poparciu modelu tradycyjnego może być interpretowana jako efekt powszechnej aktywności zawodowej kobiet, którą traktuje się jako coś oczywistego i koniecznego ze względu na niewystarczające zarobki mężczyzny dla utrzymania rodziny. Tym bardziej że zdecydowana większość Polaków uczestniczących w sondażu CBOS (94\%) zgodziła się ze stwierdzeniem, że zarówno mężczyzna, jak i kobieta powinni dokładać się do budżetu gospodarstwa domowego (CBOS 2005, za: Piszczatowska, Szczepańska 2008: 162). A zatem przyzwolenie na pracę zawodową kobiet może być przez niektórych postrzegane przede wszystkim w kategoriach ekonomicznego przymusu. Jak pokazują wyniki innego badania, 52\% kobiet byłoby skłonnych zrezygnować z pracy na rzecz rodziny, gdyby pozwalały na to zarobki partnera (CBOS 2013a). Co ciekawe, taką możliwość wykorzystałoby także 37\% mężczyzn. Kobiety jednak w większości (79\%) niechętnie przystałyby na układ, w którym utrzymanie rodziny spoczywałoby na ich barkach, a partner zrezygnował z pracy zawodowej (tamże). Taka postawa wynikać może ze znajomości przez badane realiów polskiego rynku pracy - kobietom trudniej jest niż mężczyznom znaleźć zatrudnienie, są bardziej zagrożone utratą pracy i osiągają niższe zarobki.

Sprzeczne poglądy Polaków (jednoczesne popieranie tradycyjnego i partnerskiego modelu rodziny) można także interpretować, za Anną Baranowską, w następujący sposób: „można sądzić, że część respondentów, akceptując stwierdzenie, że partnerzy powinni w równym stopniu dzielić się obowiązkami zawodowymi i rodzinnymi, uważała, że w rodzinie, w której kobieta zajmuje się domem, a mężczyzna zarabia na utrzymanie, podział jest równy - w tym sensie, że jest sprawiedliwy: każdy rodzic ma swoje kompetencje i obowiązki nie obciążają go bardziej niż partnera" (Baranowska 2007: 410). Wreszcie, możliwe że jednoczesne poparcie obu modeli jest wyrazem przekonania badanych, że obie sytuacje występują w życiu społecznym i nie są sprzeczne z obowiązującymi normami, a w zależności od preferencji, okoliczności itp. wybiera się jedną z nich (tamże).

Wyniki badań prowadzonych na przestrzeni lat pokazują zmianę w ramach kulturowego modelu płci w polskim społeczeństwie (m.in. World Values Survey - WVS) (Siemieńska 2007a: 314-315; 2007b: 330-332). Mimo wspomnianej wyżej dużej liczby zwolenników tradycyjnego podziału ról wśród Polaków, można zauważyć, że liczba ta systematycznie maleje: w badaniu WVS w 1992 r. 
opowiedziało się za nim 85\% respondentów, a 10 lat później - 69\%. Wzrasta akceptacja dla łączenia przez kobiety macierzyństwa i aktywności zawodowej, co pokazuje spadek poparcia dla stwierdzenia, że praca zawodowa matek przynosi szkodę małym dzieciom ( $72 \%$ w 1992 r., 41\% w 2005 r.) (tamże). Do mniejszości należą dziś osoby będące zdania, że „dla żony ważniejsze powinno być zapewnienie mężowi warunków sprzyjających jego sukcesom zawodowym niż to, żeby mieć własne" (42,6\% kobiet i 49,7\% mężczyzn w 1992 r. i odpowiednio 27\% i 33\% w roku 2003) (Titkow, Duch-Krzystoszek 2009: 38).

W sondażu CBOS znaczna część Polaków (39\%) wyraziła opinię, że zawodowa aktywność kobiet przynosi rodzinie więcej korzyści niż strat, podczas gdy $12 \%$ było przeciwnego zdania (zdaniem $27 \%$ respondentów korzyści i straty się równoważą, a $14 \%$ badanych nie dostrzegało żadnego wpływu pracy zawodowej kobiet na życie rodzinne) (CBOS 2013a: 48). Wyniki badań pokazują także, że kobiety pracujące zawodowo cieszą się wyższym szacunkiem społecznym niż te zajmujące się domem i dziećmi (zdaniem 19\% badanych), chociaż wśród Polaków dominuje opinia, że sytuacja zawodowa kobiety nie ma znaczenia dla jej społecznej oceny (74\%) (CBOS 2013a: 40).

Z materiału empirycznego odnoszącego się do modeli ról płciowych można wywnioskować, że prace domowe przestają być traktowane jako domena kobiet. W Badaniu gospodarstw domowych w 2005 r. większość uczestniczących w nim Polaków (71\% kobiet i 63\% mężczyzn) wyraziła przekonanie, że mężczyzna bez względu na sytuację powinien brać udział w wykonywaniu obowiązków domowych (Kotowska, Giza-Poleszczuk 2010: 63). „Zdania, że prace domowe nie są zajęciem dla mężczyzny bądź że mężczyźni nie są w stanie wykonywać prac domowych, należą do absolutnej mniejszości” (tamże). Z kolei jednak w innym ogólnopolskim badaniu z 2002 roku w ramach projektu Nieodpłatna praca kobiet, znaczna część Polaków $(65,4 \%)$ przyznała, że pranie, gotowanie, sprzątanie to naturalny obowiązek kobiety (za: Duch-Krzystoszek 2007: 132).

Kulturowe modele ról rodzicielskich w polskim społeczeństwie opierają się na przekonaniu (93\% Polaków), że wychowaniem dzieci powinni w równym stopniu zajmować się i matka, i ojciec (Titkow i in. 2004a: 213). Od obojga rodziców oczekuje się takiego samego poświęcenia dla potomstwa: większość Polaków (66,5\% kobiet i 67,3\%) jest zdania, że „matka powinna w swoim życiu zrobić dla dziecka (dzieci) wszystko, co możliwe, nawet gdy dzieje się to kosztem jej własnego dobra" i zgadza się, że dotyczy to także ojca (64,5\% kobiet i 67\% mężczyzn) (tamże: 211). Jednocześnie zdecydowana większość Polaków (85,4\% badanych) nie ma wątpliwości, że małe dziecko (do 3 lat) powinno być pod opieką matki, rezygnującej na ten czas z pracy zawodowej (Titkow, Duch-Krzystoszek 2009: 38). Duża część przedstawicieli obu płci zgadza się, że „kobiety lepiej niż mężczyźni nadają się do opieki nad dziećmi” ze względu na posiadany przez nie instynkt macierzyński (41,6\% mężczyzn, 40,5\% kobiet) i naturalne predyspozycje do zajmowania się potomstwem (34,2\% mężczyzn i 31,7\% kobiet wskazało, 
że kobiety są bardziej cierpliwe i skłonne do poświęceń, odpowiednio $23,5 \%$ i 17,1\% uznało, że „natura - geny, hormony - przeznaczyła je do tego”) (Roszak 2015). Warto jednak zauważyć, że stosunkowo dużo Polaków (ok. 40\%) nie zgadza się z opinią o wyższości kobiet nad mężczyznami w opiece nad dziećmi (31,7\% mężczyzn i 42,5\% kobiet) (tamże). Zmniejsza się odsetek badanych przekonanych, że w przypadku rozwodu dzieci powinny zostać z matką (tamże).

\subsubsection{Wzory macierzyństwa i ojcostwa}

Analiza wzorów ról płciowych i rodzicielskich dominujących w polskim społeczeństwie wskazuje wyraźnie, że bliższe są one modelowi tradycyjnemu niż partnerskiemu. W przywoływanym już sondażu CBOS pytano Polaków nie tylko o preferowany model rodziny, ale także o realizowany wzór podziału ról płciowych w ich związkach. Jak pokazują wyniki, partnerstwo udaje się realizować w rodzinach $27 \%$ respondentów, model nieproporcjonalny żeński i tradycyjny odpowiednio w 23\% i 20\% małżeństw i konkubinatów badanych (CBOS 2013a: 15). Jak podkreślają autorzy badania, ,realizowaniu modelu partnerskiego sprzyja młodszy wiek, zamieszkiwanie w mieście (szczególnie w dużej aglomeracji powyżej 500 tys. ludności), wyższy poziom wykształcenia, dobra sytuacja finansowa, pozostawanie w stanie wolnym oraz nieposiadanie dzieci (sic!)" (tamże).

$\mathrm{W}$ większości rodzin mamy do czynienia z nierównym podziałem obowiązków domowych na niekorzyść kobiet (Titkow i in. 2004a: 108-110; CBOS 2013a). Jak stwierdzają Anna Titkow i Danuta Duch-Krzystoszek (2009: 42) „prace domowe mają swoją płeć”. Przy czym większość z nich można określić jako „kobiece”. Należą do nich: przygotowanie posiłków, sprzątanie, zmywanie naczyń, pranie, prasowanie, gruntowne porządki oraz codzienne zakupy (Titkow i in. 2004a: 108-110; Titkow, Duch-Krzystoszek 2009: 42; CBOS 2013a). Mężczyźni natomiast „pilnują, aby sprzęt domowy działał bez zastrzeżeń”, wykonują lub zlecają naprawy, a także wykonują prace wymagające dużej siły fizycznej, takie jak noszenie wody czy przygotowanie opału (o ile jest taka potrzeba) (tamże).

Wyniki „Badania gospodarstw domowych” z 2005 r. pokazują, że kobiety poświęcają na prace domowe średnio 20,5 godziny tygodniowo, mężczyźni - 12,5 godziny, w przypadku osób pozostających w związku małżeńskim czas ten wynosi odpowiednio 24,5 i 14,2 godziny (Kotowska, Giza-Poleszczuk 2010: 63). Przy czym kobiety przeznaczają więcej czasu niż mężczyźni na domowe obowiązki także w sytuacji, gdy pracują zawodowo, a ich partnerzy są bezrobotni (tamże). Według danych z międzynarodowego badania, w którym pytano o czas poświęcany nie tylko na obowiązki domowe, ale i rodzinne (także z 2005 r.), stosunek czasu przeznaczanego na nie przez kobiety i mężczyzn w polskim społeczeństwie wynosi 28,8 do 8,1 godzin (za: Chłoń-Domińczak 2010: 169).

Wyniki badań przeprowadzanych wśród Polaków pokazują, że mimo postulatów partnerstwa w rolę rodzicielską kobiet wpisana jest większość obowiązków 
i odpowiedzialności związanych z opieką i wychowywaniem dzieci. Respondenci w badaniu Nieodpłatna praca kobiet stwierdzili, że matki są odpowiedzialne za: czynności pielęgnacyjne (ubieranie, kąpiel), pilnowanie dziecka i organizowanie dla niego opieki, profilaktykę zdrowotną (badania kontrolne), wizyty lekarskie, pielęgnację dziecka w chorobie, przygotowanie przyjęć okolicznościowych dla kolegów dziecka, następnie czytanie dziecku, zabawę i wspólne spędzanie wolnego czasu, kontakty z wychowawcą w przedszkolu i szkole (Titkow i in. 2004a: 214). Ojcowie najaktywniejsi są (ale zawsze mniej aktywni od matek) w najprzyjemniejszych, można powiedzieć, zadaniach: organizowaniu dziecku rozrywki typu kino i wesołe miasteczko. Poza tym zajmują się dość często odwożeniem i przywożeniem (odprowadzaniem i przyprowadzaniem) potomka do przedszkola bądź szkoły, dalej: spędzaniem z dzieckiem wspólnego czasu i zabawą, spacerami, wreszcie czytaniem dziecku (Titkow i in. 2004a: 214). Generalnie rzecz biorąc, ,mama jest od obowiązków, tatuś od przyjemności”, jak stwierdził synek jednego z respondentów (tamże: 217). Ojcostwo w porównaniu z rolą matki wydaje się być zatem łatwiejszym i przyjemniejszym zadaniem. Nie pochłania mężczyzn w takim stopniu jak macierzyństwo kobiety. Wielu ojców nie ma regularnego, bliskiego kontaktu z dzieckiem (np. czas na zabawę i spędzanie wolnego czasu z dzieckiem mają tylko w niedziele lub wolne dni) (tamże: 219).

W tym samym badaniu podjęta została kwestia miejsca macierzyństwa i ojcostwa w koncepcji siebie kobiet i mężczyzn (Titkow i in. 2004a: 166-168). Respondenci - przedstawiciele obu płci odpowiadali na pytanie: „Kim jestem?”, wskazując trzy spośród podanych odpowiedzi ${ }^{7}$. Wyniki pokazują, że kobiety postrzegały siebie przede wszystkim jako matki $(25,9 \%)$ i żony $(23,6 \%)$. Kolejne ważne dla kobiet identyfikacje to bycie człowiekiem i bycie kobietą (każdą z nich wskazało 22,3\%). Mężczyźni identyfikowali się głównie z rodzajem ludzkim $(34,3 \%)$, na drugim miejscu pod względem częstości wyborów znalazła się rola męża, na trzecim - bycie mężczyzną. Ojcostwo jako rolę pierwszoplanową wskazało jedynie $7,9 \%$. Wyniki te pokazują wyraźnie różne znaczenie ról rodzicielskich dla kobiet i dla mężczyzn - „Matką, przede wszystkim, określa się co czwarta kobieta, Ojcem blisko co trzynasty mężczyzna. Dla mężczyzn ważniejsze od relacji z dzieckiem pozostają relacje z żoną i bycie Mężem" (Titkow i in. 2004a: 167). Co ciekawe, nie zmienia tego fakt posiadania dziecka. W koncepcji siebie mężczyzn pełniących funkcje rodzicielskie na pierwsze miejsce wysuwa się rola męża $(40,1 \%)$, za nią dopiero plasuje się bycie człowiekiem $(27,5 \%)$.

${ }^{7}$ Respondenci, w badaniu reprezentatywnym, proszeni byli o wskazanie trzech odpowiedzi spośród następujących: jestem żoną/mężem; pracownicą/pracownikiem; matką/ojcem; szefową/ szefem; człowiekiem; kochanką/kochankiem; Polką/Polakiem; kobietą/mężczyzną; siostrą/bratem; córką/synem. Tu analizowane są tylko te odpowiedzi, które były wskazywane na pierwszym miejscu i mogą być traktowane jako pierwszoplanowa, najważniejsza identyfikacja (jestem przede wszystkim...) (Titkow $i$ in. 2004: 166). 
Rola ojca jest najważniejsza dla prawie co dziewiątego mężczyzny mającego potomstwo $(11,3 \%)$, podczas gdy rolę rodzicielską jako pierwszoplanową wskazuje prawie co trzecia matka (34,4\%). Jak zauważają autorki badania, te różnice w hierarchiach życiowych ról kobiet i mężczyzn pokazują, że rodzina oznacza co innego dla przedstawicieli obu płci. „Dla kobiet rodzina to przede wszystkim dziecko, a potem mąż. Dla mężczyzn rodzina to głównie żona" (tamże: 168).

Większe obciążenie kobiet obowiązkami rodzinnymi oraz domowymi jest jednym z głównych powodów niskiej aktywności zawodowej kobiet. W 2013 roku współczynnik aktywności zawodowej kobiet ${ }^{8}$ wynosił 48,5\%, wskaźnik zatrudnienia kobiet $^{9}-43,4 \%$, (dla mężczyzn wskaźniki te wynosiły odpowiednio 64,4\% i 58,5\%) (GUS 2014: 26, 27). Jak zauważa Urszula Sztanderska, ,patrząc od strony podaży pracy (gotowości do podejmowania pracy zawodowej przy określonym poziomie płac), decyzje kobiet o pracy zawodowej są silnie uwarunkowane przez skalę obowiązków domowych, w tym związanych z urodzeniem i wychowywaniem dzieci" (Sztanderska 2005: 5). Dane pokazują, że ponad jedna trzecia biernych zawodowo kobiet (37\%) jako powód rezygnacji z pracy wskazuje „obowiązki rodzinne i związane z prowadzeniem domu” (GUS 2014: 35). Dotyczy to $63,3 \%$ kobiet nieposzukujących pracy w wieku 25-34 lata (tamże: 131). Praca zawodowa kobiet jest więc traktowana jako „metoda uzupełniania dochodów rodziny, podporządkowana fazom życia rodziny" (Kotowska i in. 2007: 439). Dużą rolę odgrywają tu z jednej strony omówione społeczne oczekiwania, że macierzyństwo będzie najważniejszą rolą kobiety (przynajmniej w pewnym okresie jej życia), z drugiej strony - określona polityka rodzinna umożliwiająca (bądź wręcz przeciwnie) łączenie aktywności zawodowej z życiem rodzinnym.

Podsumowując, przedstawione tu wyniki badań reprezentatywnych dla polskiego społeczeństwa pokazują, że zarówno modele jak i wzory dotyczące ról płciowych i rodzicielskich są pewną ,kompozycją, mozaiką” elementów tradycyjnych i nowoczesnych (Piszczatowska, Szczepańska 2008: 150). Przy czym, jak pokazuje analiza podziału obowiązków domowych i rodzicielskich, nowoczesnemu modelowi (przekonanie o pożądanym równym zaangażowaniu obojga partnerów) towarzyszą często tradycyjne, konserwatywne wzory zachowań. Należy także mieć świadomość, że na podstawie tego typu badań zyskujemy obraz dominujących w społeczeństwie przekonań oraz zachowań (co zresztą odpowiada założonemu celowi autorki w niniejszym podrozdziale). Dostępnych jest wiele opracowań pokazujących „nowe” macierzyństwo i „nowe” ojcostwo jako wzory „wyłaniające się" (,zaczątkowe”), które „zyskują sobie dopiero grunt w praktyce społecznej" (Kłoskowska 1959: 49). Przykładem mogą tu być prace Anety

${ }^{8}$ Udział osób pracujących i poszukujących pracy, tj. zarejestrowanych bezrobotnych w ogóle kobiet w wieku 15 i więcej lat.

${ }^{9}$ Procentowy udział osób mających pracę w ogóle kobiet w wieku 15 i więcej lat. 
Grygiel (2006, 2010), Mikołaja Gębki (2007), Bogusławy Budrowskiej (2008), Małgorzaty Fuszary (2008), Małgorzaty Sikorskiej (2009a, 2009b), Marty Olcoń-Kubickiej (2009), czy Pawła Kubickiego (2009). Należy także pamiętać, że w celu zbadania modeli społecznych analizuje się również „słowne, obrazowe lub jakiekolwiek symboliczne przedstawienia ludzkiego zachowania", czyli modele popularyzowane w przekazach kultury masowej (Kłoskowska 1959: 50). Wyniki takich analiz, przedstawione m.in. w pracach Krzysztofa Arcimowicza (2003, 2007, 2010, 2011) i Beaty Łaciak (2005, 2007, 2012) pokazują współwystępowanie obok siebie tradycyjnych i nowoczesnych modeli kobiecości i męskości, macierzyństwa i ojcostwa.

Jak stwierdza A. Kłoskowska, ,wzory zaczątkowe rozciągają się zawsze tylko na pewien wycinek społeczeństwa" (Kłoskowska 1959: 49). Uwzględnienie cech społeczno-demograficznych respondentów uczestniczących w omawianych ogólnopolskich badaniach pokazuje, że stosunkowo najmniej tradycyjne poglądy na role kobiet i mężczyzn mają osoby młode, $\mathrm{z}$ wyższym wykształceniem, pracujący zawodowo mieszkańcy dużych miast (Baranowska 2007; CBOS 2013a). Przedstawiciele tych kategorii społecznych realizują najczęściej nowe wzory macierzyństwa i ojcostwa, opisywane w wymienionych wyżej opracowaniach. Ich także dotyczy niniejsza praca, której celem jest sprawdzenie, czy ten deklarowany egalitaryzm i nowoczesność poglądów przekłada się na bycie nowoczesną kobietą/mężczyzną, matką/ojcem. 



\section{CZĘŚĆ II \\ WZORY RODZICIELSTWA MŁODYCH \\ WYKSZTAŁCONYCH POLEK I POLAKÓW \\ WYNIKI EMPIRYCZNYCH BADAŃ WŁASNYCH}

\section{Rozdział 5. Cel, problematyka i założenia metodologiczne badań własnych}

\subsection{Cel i przedmiot badania}

Celem badań własnych przeprowadzonych przez autorkę było ustalenie, czy wzory macierzyństwa i ojcostwa realizowane przez młode wykształcone Polki i Polaków odnoszą się do tradycyjnego czy nowoczesnego modelu płci. Odwołując się do teorii strukturacji - czy przedstawiciele wybranej kategorii społecznej swoimi działaniami odtwarzają, reprodukują „odwieczny”, tradycyjny, utarty sposób definiowania i realizowania ról rodzicielskich (wzory odpowiadające tradycyjnemu modelowi płci), czy też dokonują kulturowej zmiany na rzecz nowoczesnego rodzicielstwa (wzory odpowiadające nowoczesnemu modelowi płci). Przy czym, trzeba tu zaznaczyć, że w świetle teorii strukturacji A. Giddensa reprodukowanie struktury jest zarazem jej wytwarzaniem, „twórczym przedsięwzięciem jednostki”. Można jednak odróżnić działania opierające się na powielaniu istniejących wzorów kulturowych i działania innowacyjne, polegające na wytworzeniu zupełnie nowych wzorów zachowań.

Przedmiotem zainteresowania były $\mathrm{z}$ jednej strony kulturowe koncepcje kobiecości i męskości (struktura), z drugiej strony - zachowania jednostek jako kobiet/mężczyzn, matek/ojców (podmiotowe działania społecznych aktorów). Stosując aparat pojęciowy teorii strukturacji, można powiedzieć, że analizie poddano praktyki społeczne dotyczące bycia osobą o określonej płci oraz rodzicem, w których społeczni aktorzy odwołują się do strukturalnie narzuconych nakazów, reprodukując je i tworząc zarazem poprzez ich interpretację i selekcję. Mówiąc o strukturze, rozumiemy ją jako społeczne ramy, w których funkcjonuje jednostka, zespół zewnętrznych społecznych uwarunkowań jej działań, będący jednocześnie ich warunkiem i rezultatem, ograniczeniem i możliwością. Zgodnie z koncepcją A. Giddensa, według której na strukturę składają się „reguły i zasoby uwikłane w proces społecznej reprodukcji”, kulturowe modele płci oraz ról rodzicielskich 
są regułami, dostarczającymi jednostkom znaczeń, schematów interpretacyjnych oraz wskazówek działania. Społeczni aktorzy w swoich rutynowych działaniach (wzory) - jako kobiety, mężczyźni, matki, ojcowie - odwołują się do nich i wiedzą, jak postępować. Są to reguły intensywne (stale przywoływane przez aktorów w codziennej działalności, w której jest się nieustannie, bez przerwy osobą o określonej płci), raczej milczące niż dyskursywne (choć mamy wyrażone słownie stereotypowe określenia dotyczące kobiet i mężczyzn, matek i ojców), nieformalne, silnie usankcjonowane (określone społeczne oczekiwania co do sposobu pełnienia ról płciowych i rodzicielskich). Mamy przy tym świadomość, że analizując wypowiedzi badanych opowiadających o swoich społecznych praktykach związanych z pełnieniem ról rodzicielskich, poznajemy nie bezpośrednio same reguły, ale ich interpretacje. Sięgamy do wiedzy dyskursywnej badanych, obejmującej to, co ludzie potrafią powiedzieć na temat własnych działań.

Prezentowane opracowanie ma charakter teoretyczno-empiryczny. Pierwszy etap badania stanowiła analiza koncepcji kobiecości i męskości funkcjonujących we współczesnym społeczeństwie w oparciu o literaturę przedmiotu. W rezultacie skonstruowano idealne typy kulturowych modeli płci - tradycyjnego i nowoczesnego oraz mieszczących się w nich modeli roli matki i ojca. Stanowią one, zgodnie z ujęciem Maxa Webera, teoretyczne konstrukcje służące do analizy empirycznego materiału (Weber 1985: 80-93). Jak określił to Jerzy Szacki, „typu idealnego nie odkrywa się w empirycznej rzeczywistości, typ idealny się tworzy, ażeby tę rzeczywistość badać i rozumieć, nie oczekując wszakże, iż będzie z nim kiedykolwiek całkowicie zgodna" (Szacki 2005: 465). Ową empiryczną rzeczywistością były w tym przypadku wzory zachowań przedstawicieli wybranej kategorii społecznej w rolach rodzicielskich.

W koncepcji Antoniny Kłoskowskiej modele i wzory traktuje się jako dwie płaszczyzny badań zachowania społecznego - faktyczne zachowania oraz ,towarzyszące im refleksje, normy i oceny" (Kłoskowska 1962: 35, 37). Te dwa wymiary w rzeczywistości społecznej nakładają się na siebie, są ze sobą ściśle powiązane. Trudność analitycznego rozróżnienia, oddzielenia modelu od wzoru potwierdziła analiza zebranego materiału empirycznego, który stanowiły wypowiedzi badanych na temat pełnienia przez nich ról rodzicielskich. Respondenci opowiadali o realizowanych przez siebie rolach matki i ojca, wyjaśniając, uzasadniając, racjonalizując codzienne działania poprzez odwoływanie się do swojego sposobu rozumienia kobiecości i męskości oraz macierzyństwa i ojcostwa. Uzyskaliśmy więc informacje na temat faktycznych zachowań jednostek (czyli wzór w rozumieniu A. Kłoskowskiej) oraz poglądów, refleksji, norm, będących podstawą tych zachowań (można tu, za cytowaną autorką, mówić o modelu środowiskowym, dominującym, powszechnym w danym środowisku społecznym).

Na potrzeby pracy przyjęto, że mianem wzoru macierzyństwa i ojcostwa młodych wykształconych Polek i Polaków będzie określany łącznie sposób realizowania przez nich ról rodzicielskich wraz z towarzyszącymi im przeko- 
naniami. Odwołując się do przyjętej koncepcji roli społecznej, przedmiotem badania była osobowościowa definicja roli, w której zawiera się własna koncepcja roli jednostki - nakazy i wymogi społeczne zinterpretowane przez jednostkę oraz aspekt behawioralny - odgrywanie roli. Zgodnie z tym ujęciem, sposób pełnienia roli ściśle wiąże się z przekonaniami na temat istotnych dla jej realizacji cech, predyspozycji, zachowań. Płaszczyznę odniesienia dla analizowanych poglądów i doświadczeń młodych, wykształconych Polaków stanowił wspominany tradycyjny i nowoczesny model kobiecości i męskości oraz zawierające się w nich modele ról rodzicielskich.

Praca ta mieści się w nurcie rozważań i badań, w ramach których jednostki traktuje się jako podmioty, których osobowościowe predyspozycje, potrzeby, uczucia, wartości, zainteresowania mają wpływ na sposób pełnienia przez nie ról społecznych. W odniesieniu do rodzicielstwa takie ujęcie po raz pierwszy pojawiło się w tekstach feministycznych w latach dziewięćdziesiątych, kiedy to macierzyństwo zaczęto analizować nie z perspektywy rozwijającego się dziecka, ale z perspektywy kobiety (Budrowska 2000: 88). W centrum zainteresowania badaczy zamiast relacji matka - dziecko znalazła się relacja matka - społeczeństwo, czyli indywidualne, osobiste doświadczenia macierzyństwa w kontekście społecznych konstrukcji ról płciowych i rodzicielskich (tamże). W niniejszej pracy interesuje nas właśnie sposób realizowania roli (wzór) kobiety/mężczyzny, matki/ ojca, w odniesieniu do ich kulturowych modeli.

Zajmowanie się tylko społecznymi modelami sprawia, że znika jednostka jako podmiot i społeczni aktorzy sprowadzeni są do biernych odtwórców ról (z czym mamy do czynienia w normatywnych, strukturalno-funkcjonalnych koncepcjach roli społecznej). $Z$ kolei nie jest możliwe badanie indywidualnych doświadczeń bez odniesienia do kulturowego kontekstu, w jakim członkowie społeczeństwa funkcjonują, do którego się odnoszą w swoich sposobach realizowania ról społecznych. Taka „podwójna perspektywa” pozwala na uchwycenie dialektycznej relacji między jednostką i społeczeństwem.

\subsection{Problematyka badania}

Główny problem badawczy stanowiło określenie, jakie są wzory macierzyństwa i ojcostwa realizowane przez młode wykształcone Polki i Polaków - tradycyjne czy nowoczesne. Stworzone typy idealne tradycyjnego i nowoczesnego modelu płci wraz z modelami ról rodzicielskich pozwoliły na wyodrębnienie niżej przedstawionych wskaźników „tradycji” i „nowoczesności”.

Wskaźnikami tradycyjnego modelu płci oraz macierzyństwa i ojcostwa są:

- traktowanie kobiecości i męskości, a tym samym macierzyństwa i ojcostwa, jako różnych, opierających się na innych, przeciwstawnych cechach i zadaniach;

- podział rodzicielskich zadań ze względu na płeć; 
- uzasadnianie podziału ról naturą i różnicami biologicznymi;

- traktowanie macierzyństwa jako powołania kobiety i przekonanie o istnieniu instynktu macierzyńskiego;

- traktowanie roli matki jako pierwszoplanowej i ważniejszej w życiu dziecka niż rola ojca;

- odrzucanie bezdzietności: nakaz wypełniania biologicznych ról przez przedstawicieli obu płci;

- przypisywanie różnej wagi macierzyństwu i ojcostwu w życiu kobiety i mężczyzny (rola matki jako najważniejsza rola kobiety, rola ojca jako konieczna dla bycia mężczyzną, ale będąca niejako na drugim planie wobec ról w sferze publicznej) i w związku z tym przypisywanie odmiennych doświadczeń związanych z rolą matki i ojca: macierzyństwo jako istotne doświadczenie kobiety, wiążące się z totalną zmianą jej życia, ojcostwo jako niezbyt znaczące doświadczenie, nie wywołujące większych zmian w życiu mężczyzny.

Wskaźnikami nowoczesnego modelu płci oraz macierzyństwa i ojcostwa jest negacja wyżej wymienionych postaw i zachowań, a zatem:

- nieprzypisywanie specyficznych cech i zadań ze względu na płeć (brak podziału cech, zachowań, zadań rodzicielskich, ról ze względu na płeć);

- odrzucanie esencjalizmu biologicznego, odwoływanie się do kultury jako źródła istniejących podziałów płciowych;

- kwestionowanie istnienia instynktu macierzyńskiego;

- akceptacja bezdzietności, brak nakazu macierzyństwa i ojcostwa;

- traktowanie kobiet i mężczyzn jako równie ważnych rodziców w życiu dziecka, mających podobne obowiązki rodzicielskie i podobną relację z dzieckiem;

- partnerstwo i równość w wykonywaniu obowiązków rodzicielskich, podział ról jako efekt negocjacji i uzgodnień;

- przekonanie o podobnych przeżyciach i doświadczeniach kobiet i mężczyzn związanych z zostaniem rodzicem.

W badaniu empirycznym poznajemy wzory macierzyństwa i ojcostwa młodych wykształconych Polaków, przez które rozumiemy faktyczne zachowania jednostek w rolach rodzicielskich oraz towarzyszące im przekonania, refleksje, racjonalizacje itp. W celu skonfrontowania ich $\mathrm{z}$ tradycyjnym i nowoczesnym modelem płci, postawiono następujące pytania badawcze:

1. Jak młode wykształcone Polki i Polacy definiują/rozumieją kobiecość i męskość - czy ich przekonania na temat roli kobiety i mężczyzny odwołują się do tradycyjnego czy nowoczesnego modelu płci? W ramach tego obszaru kluczowe było rozstrzygnięcie następujących szczegółowych kwestii:

- Co oznacza dla młodych wykształconych ludzi bycie kobietą i bycie mężczyzną? Jakie społeczne oczekiwania (dotyczące cech, pełnionych ról społecznych) w ich przekonaniu wiążą się z kobiecością i męskością?

- Jak postrzegają relację kobiecość - męskość - czy odwołują się tu do podziału cech i ról czy też kwestionują płciową specjalizację? 
- Do jakich argumentów (biologia, natura versus kultura) odwołują się w wyjaśnianiu różnic między kobietami i mężczyznami? Jak odnoszą się do macierzyństwa i ojcostwa jako niezbędnego elementu kobiecości i męskości?

W związku z przyjęciem założenia o tym, że młodzi wykształceni ludzie, mieszkańcy dużych miast, stanowią forpocztę kulturowych zmian od „tradycji” ku „,nowoczesności”, oraz że na tle polskiego społeczeństwa cechują się oni stosunkowo wysokim stopniem podmiotowości w samookreślaniu się i dokonywanych wyborach życiowych, sformułowano następującą hipotezę. Uznano, że uczestnicy badania będą definiować kobiecość i męskość, odwołując się do nowoczesnego modelu płci: odrzucać stereotypy płciowe i tradycyjny podział ról, wskazywać na kulturowe źródła istniejących podziałów na kobiece - męskie oraz kwestionować traktowanie macierzyństwa i ojcostwa jako koniecznego elementu roli płciowej. A zatem dokonywać będą zmiany społecznej struktury - społecznych reguł dotyczących bycia kobietą, mężczyzną na rzecz nowoczesnego sposobu określania płci.

2. Jakie wzory roli matki i roli ojca realizują uczestniczący w badaniu młode wykształcone Polki i Polacy - jakie cechy, zachowania i zadania związane są w ich przekonaniu z pelnieniem tych ról? Czy ich sposób rozumienia i realizowania ról rodzicielskich odwołuje się do tradycyjnego czy nowoczesnego modelu płci? W odniesieniu do tego problemu badawczego pomocne było uzyskanie odpowiedzi na następujące szczegółowe pytania badawcze:

- Co znaczy dla młodych wykształconych ludzi być matką i być ojcem?

- Z jakimi zadaniami wiąże się bycie matką/ojcem? Czy w ich rodzinie inne czynności są przypisane matce a inne ojcu, czy są zamiennie wykonywane przez oboje rodziców? Czy młodzi wykształceni ludzie traktują role ojca i matki jako role cechujące się określonymi odrębnymi zadaniami i funkcjami czy też według nich można mówić nie tyle o specyfice macierzyństwa i ojcostwa, co o rodzicielstwie jako takim, nie o roli matki czy ojca, ale o roli rodzica? Jeżeli według nich istnieje specyfika roli matki i ojca, to na czym ona polega?

- Do jakich argumentów (biologia, natura versus kultura) odwołują się w wyjaśnianiu ewentualnych różnic między rolą matki i rolą ojca?

- Jak młodzi ludzie rozumieją partnerstwo w wykonywaniu zadań rodzicielskich przez matkę i ojca? Czy według nich takie partnerstwo jest możliwe? Czy $i$ jak realizują je w swoich rodzinach?

- Jaka jest geneza ich wzorów macierzyństwa i ojcostwa - czy pełniąc role rodzicielskie wzorują się na swoich matkach i ojcach?

Przyjęto następującą hipotezę: wzory ról rodzicielskich realizowanych przez młode wykształcone Polki i Polaków odpowiadać będą nowoczesnemu modelowi macierzyństwa i ojcostwa, mieszczącemu się w nowoczesnym modelu płci. Uczestnicy badania będą dokonywać zmiany tradycyjnych reguł dotyczących rodzicielstwa, kwestionując specyfikę macierzyństwa i ojcostwa oraz traktując rolę matki i ojca jako podobne role (oparte na tych samych cechach i zadaniach) 
i równorzędne. Ich wzajemna relacja będzie miała partnerski charakter i będzie opierać się na takim samym (porównywalnym) zaangażowaniu kobiety i mężczyzny w opiekę nad dzieckiem.

3. Jak, w odczuciu badanych, zmienia się życie kobiety i mężczyzny po pojawieniu się dziecka? W analizie osobistych doświadczeń związanych z byciem matką/ojcem, uwzględniono następujące szczegółowe zagadnienia:

- Jak zmienia się życie kobiety i mężczyzny po tym, jak zostają rodzicami?

- Czy i jak zmienia się ich sposób postrzegania siebie samych? Jak zmienia ich bycie rodzicem?

W stosunku do tak postawionych pytań badawczych sformułowano następującą hipotezę: pojawienie się dziecka w życiu uczestników badania pociąga za sobą doświadczenie szeroko rozumianej zmiany, dotyczące zarówno kobiet, jak i mężczyzn. Uczestniczące w badaniu matki i ojcowie będą mieć podobne odczucia i doświadczenia, co wynika z podobnego zaangażowania obojga rodziców w opiekę nad dzieckiem oraz traktowania macierzyństwa i ojcostwa jako podobnych i równorzędnych form rodzicielstwa. Odpowiada to nowoczesnemu modelowi płci i rodzicielstwa, w ramach którego role rodzicielskie traktuje się jako odgrywające równie ważną rolę w życiu kobiety i mężczyzny.

Analiza kulturowych modeli kobiecości i męskości oraz macierzyństwa i ojcostwa pokazała, że tradycyjny i nowoczesny model płci i rodzicielstwa różni się m.in. wzorami przeżywania rodzicielstwa przez kobiety i mężczyzn. W modelu konserwatywnym (odwołując się do terminologii A. Kłoskowskiej) odmawia się mężczyznom silnych przeżyć emocjonalnych związanych z narodzinami dziecka (lub zupełnie je ignoruje), kobietom natomiast przypisuje się jedynie pozytywne odczucia (idealizacja macierzyństwa). W modelu nowoczesnym „uwalnia się” emocje jednostek i pozwala na przeżywanie życiowych wydarzeń na swój własny sposób. Interesujące zatem wydało się zbadanie sposobu doświadczania rodzicielstwa przez matki i ojców z wybranej społecznej kategorii. Kluczowym pojęciem $\mathrm{w}$ analizie doświadczenia zostania rodzicem jest pojęcie zmiany. Tym bardziej że narodziny dziecka są traktowane jako ważne życiowe wydarzenie, przełomowy moment czy „kryzys rozwojowy” (Budrowska 2000; Bartosz 2002; Dąbrowska-Wnuk 2007; Skowrońska 2008). W badaniu B. Budrowskiej większość kobiet była zgodna co do tego, że macierzyństwo to punkt zwrotny w ich życiu: „najogólniej rzecz ujmując, spostrzegają one doświadczenie urodzenia dziecka jako przyczynę przeogromnych, wszechobejmujących zmian w życiu" (Budrowska 2000: 240). Stąd pytanie o różnego rodzaju zmiany, jakie wywołuje w życiu nie tylko kobiet, ale i mężczyzn fakt zostania rodzicem.

Dostępne opracowania (m.in. na gruncie socjologii praca B. Budrowskiej Macierzyństwo jako punkt zwrotny w życiu kobiety z 2000 roku, na gruncie psychologii - B. Bartosz Doświadczanie macierzyństwa: analiza narracji autobiograficznych z 2002 r.) odwołują się do subiektywnych doświadczeń kobiet związanych z pełnieniem roli matki. Brak podobnych prac dotyczących przeżyć 
mężczyzn w rolach ojców można interpretować jako przejaw tradycyjnego modelu płci, zgodnie z którym zostanie rodzicem nie jest wydarzeniem wywołującym tak istotne zmiany w życiu mężczyzny jak macierzyństwo w życiu kobiety. W niniejszym badaniu starano się poznać perspektywę rodziców obu płci i porównać ich doświadczenia związane z podjęciem nowej roli społecznej.

Celem badania nie była odpowiedź na pytanie, kto - kobiety czy mężczyźni w badanej grupie - ma bardziej tradycyjne, a kto bardziej nowoczesne poglądy. Tym bardziej że jak pokazują wyniki przeprowadzanych wcześniej badań społecznych, ,istnieje znaczne podobieństwo opinii pomiędzy mężczyznami i kobietami należącymi do tej samej generacji i posiadającymi takie samo wykształcenie” (Siemieńska 2007a: 316). Badacze wskazują na „strukturalną i kulturową odrębność" młodego pokolenia (Warzywoda-Kruszyńska, Krzyszkowski 1991: 230). W analizie zebranego materiału zwracano uwagę na płeć wypowiadających się, wskazując zarówno podobieństwa, jak i różnice między poglądami, zachowaniami, doświadczeniami matek i ojców. Uczestnicy badania byli dla nas jednak przede wszystkim przedstawicielami wybranej kategorii społecznej, podobnymi do siebie pod względem wieku, wykształcenia, miejsca zamieszkania, aktywności zawodowej, wieku posiadanych dzieci. Ponieważ właśnie młodzi, wykształceni mieszkańcy wielkich miast wyróżniają się na tle innych społecznych kategorii w Polsce swoimi przekonaniami dotyczącymi ról kobiet i mężczyzn, chciano przyjrzeć się bliżej realizowanym przez nich wzorom ról rodzicielskich. Celem było określenie, na ile podobni są oni w swoim rodzicielstwie, co ich różni, jakie typy wzorów macierzyństwa i ojcostwa realizują.

\subsection{Badana zbiorowość}

Badaną zbiorowość stanowiły kobiety i mężczyźni, mieszkańcy Łodzi, w wieku 25-35 lat, posiadający wyższe wykształcenie, będący rodzicami (biologicznymi) małych dzieci (do lat 3), pracujący zawodowo (ewentualnie przebywający na urlopie macierzyńskim lub rodzicielskim), których partnerzy również pracują zawodowo. Wyniki badań pokazują, że to przede wszystkim osoby młode, wykształcone i mieszkające w dużych miastach opowiadają się za partnerskim modelem rodziny oraz realizują go we własnych rodzinach, stąd taki dobór respondentów do badania. Dodatkowo, wybór osób, w których związkach/małżeństwach i kobieta i mężczyzna pracują zawodowo wynikał z założenia, że w rodzinach tych partnerzy starają się wypracować rozwiązania umożliwiające każdemu z nich łączenie aktywności zawodowej ze sferą rodzinną - domową.

W sumie w badaniu wzięło udział 36 kobiet oraz 36 mężczyzn (20 w wywiadach z parami, 16 - w zogniskowanych wywiadach grupowych). Próba miała charakter celowy. W przypadku badania par rodziców zastosowanie znalazła metoda kuli śnieżnej (Babbie 2008: 213). Zbiorowość badana była niewielka, ale 
homogeniczna pod względem cech społeczno-demograficznych, odpowiadająca potrzebom jakościowego badania. Próba ta nie ma charakteru reprezentatywnego dla opisanej wyżej kategorii społecznej, stąd wniosków odnoszących się do realizowanych przez badanych wzorów ról płciowych i rodzicielskich nie można rozciągać na wszystkich młodych wykształconych Polaków, będących rodzicami. Należy mieć świadomość, że w zbiorowości tej są także rodziny oparte na tradycyjnym podziale ról, nawet jeżeli nie było żadnego takiego przypadku wśród badanych. Wynika to chociażby z przeprowadzanych wywiadów, w których respondenci przyznawali, że mają wśród znajomych młodych rodziców, którzy realizują zupełnie inne wzory macierzyństwa i ojcostwa. Ale, jak stwierdziła jedna $\mathrm{z}$ uczestniczek badania, takie osoby nie chciałyby wziąć udziału w badaniu, gdyż na temat rodzicielstwa mogłaby się wypowiadać jedynie matka, ojciec natomiast jako funkcjonujący niejako z boku relacji matka - dziecko nie miałby zbyt wiele do powiedzenia. Wydaje się, że w zbiorowości badanych uznawano, że hołdowanie tradycyjnemu modelowi płci jest czymś niewłaściwym, „niepoprawnym politycznie", do czego nie wypada się przyznawać.

\subsection{Metoda i techniki badawcze}

Podjęta problematyka badawcza i zainteresowanie jednostkowymi doświadczeniami, odnoszonymi do kulturowych modeli płci, wymagała odwołania do „bazy metodologicznej” symbolicznego interakcjonizmu (Hałas 1981: 110). Chodzi tu o dotarcie do ,aktualnego doświadczenia uczestnika życia społecznego", jego punktu widzenia, zdroworozsądkowej wiedzy, sposobu definiowania sytuacji oraz łączenie przypisywanych przez jednostkę znaczeń „ze społecznymi kręgami, do których on przynależy" (tamże: 113). Poznajemy tu zjawisko rodzicielstwa nie jako obiektywny fakt, ale jako zjawisko doświadczane i przeżywane subiektywnie, któremu jednostka nadaje określone znaczenie, definiuje je i interpretuje, odwołując się przy tym do społecznych reguł i znaczeń. Przyjmujemy tu, odwołując się do dorobku socjologii fenomenologicznej A. Schütza, że „,rzeczywistość społeczna dana jest tylko jako jej interpretacje dokonywane przez uczestników życia społecznego, oddziałujących wzajemnie na siebie i w toku tej interakcji «konstruujących» swój intersubiektywny świat” (Szacki 2005: 863). Zatem ,socjologia ma do czynienia wyłącznie ze światem już opisanym i zinterpretowanym przez samych uczestników życia społecznego, będąc w związku z tym nieuchronnie interpretacja interpretacji”' (Szacki, 2005: 864). W niniejszej pracy interesuje nas „świat przeżywany” młodych rodziców, ich „definicje sytuacji” (Ritzer 2004: 285, 286; Hałas 2006a: 139).

Takie podejście badawcze nawiązuje także do koncepcji współczynnika humanistycznego Floriana Znanieckiego (Znaniecki 1988; 1992). Odwołanie się tu do naukowego dorobku F. Znanieckiego jest tym bardziej uzasadnione, że jest on 
postrzegany jako prekursor symbolicznego interakcjonizmu (Bauman 1999b: 99). Co więcej, zwraca się uwagę, że przyjęta w pracy teoria strukturacji A. Giddensa przypomina w dużej mierze sposób postrzegania jednostki i społeczeństwa przyjęty przez F. Znanieckiego (Bauman 1999b: 103; Hałas 2006b: 154). Jak stwierdza Elżbieta Hałas, ,problem podmiotowości i struktury opracowywany był przez Znanieckiego na długo przedtem zanim podjął go Giddens" (Hałas 2006b: 154). Biorąc pod uwagę, że także przyjęta koncepcja modelu i wzoru A. Kłoskowskiej miała swoje źródło w pracach F. Znanieckiego, można powiedzieć, że niniejsza praca w każdym niemal aspekcie nawiązuje do teorii tego autora, mieszcząc się w nurcie rozwijanej przez niego socjologii humanistycznej. Florian Znaniecki podkreślał, że socjologowi dostępny jest jedynie „świat cudzych «świadomości»” rzeczywistość ze „współczynnikiem humanistycznym”, co wiąże się z tym, że „zjawiska kulturalne, przedmioty humanistycznego badania jako przedmioty teoretycznej refleksji są już przedmiotami komuś danymi w doświadczeniu lub czyimiś świadomymi czynnościami” (Znaniecki 1988: 24, 25). Według F. Znanieckiego osobiste doświadczenia - samego badacza oraz innych ludzi - stanowią podstawowy materiał socjologicznej analizy (Znaniecki 2008: 185). Z tym sposobem postrzegania rzeczywistości społecznej koresponduje zarówno teoria A. Giddensa, w której przyjmuje się, że socjolog ma do czynienia ze światem uprzednio zinterpretowanym, jak i przyjęta teoria roli społecznej, zgodnie z którą nie ma ról bez pełniących ich aktorów. Badać role można zatem jedynie sięgając do doświadczeń ich wykonawców - twórców.

Zarówno powyższa koncepcja jednostki i społeczeństwa, jak i problematyka pracy wymagała zastosowania jakościowej metody badawczej. Badanie miało charakter eksploracyjny. Chodziło o dotarcie do przekonań „ugruntowanych w doświadczeniach" badanych osób, poznanie ich zachowań i towarzyszących im znaczeń i interpretacji (Rubin, Rubin 1997: 207; Silverman 2007: 40-41). Jak stwierdza Zygmunt Bauman, ,[...] rozumienie zjawisk społecznych możliwe jest tylko «od środka». [...] Znaczy to, że [socjolog - uzup. K.D.-G.] musi się w tym świecie «zanurzyć», tak by przedmiotem swego dociekania mógł uczynić doświadczenie dostępne jedynie tym, którzy w tym świecie działają" (Bauman 1999a: 27-28). Zastosowanie metody jakościowej pozwala na uniknięcie narzucania badanym siatki pojęciowej badacza, wiąże się z uznaniem kompetencji badanych, znaczenia ich osobistych doświadczeń i przeżyć oraz relacji o nich (Wyka 1989: 321). Jak stwierdza Steinar Kvale, ,[...] sądzi się, że badania jakościowe są wrażliwe na sytuację człowieka, wiążą się z empatycznym dialogiem z badanymi i mogą przyczynić się do emancypacji i wzmocnienia ich pozycji. [...]. Wywiady dają sposobność badanym, aby przekazać innym sytuację badanych z ich własnej perspektywy i własnym codziennym językiem" (Kvale 2004: 79).

Podstawę źródłową badania stanowiły wypowiedzi celowo dobranych osób, spełniających wymieniane już warunki (wiek 25-35 lat, wyższe wykształcenie, pracujący zawodowo rodzice małych dzieci). Wykorzystano techniki 
otrzymywania materiału o niskim stopniu standaryzacji, oparte na komunikowaniu bezpośrednim - wywiady swobodne mało ukierunkowane, niestrukturalizowane (Przybyłowska 1978: 63) oraz zogniskowane wywiady grupowe.

Zastosowanie pogłębionego wywiadu, opartego na „ogólnym planie zagadnień" i przyjmującego formę swobodnej rozmowy, ukierunkowanej przez prowadzącego i nastawionej na uzyskanie jak najszerszych wypowiedzi na zadany temat znajduje uzasadnienie w przyjętej perspektywie teoretycznej, stawiającej w centrum zainteresowania ,indywidualny podmiot" $i$ jego osobiste doświadczenia. ,[W wywiadzie swobodnym mało ukierunkowanym - przyp. K.D.-G.] badacz dostosowuje się do respondenta w ten sposób, że stara się uzyskać od niego informacje na temat, o którym badany wie najwięcej i który należy do jego wiedzy eksperckiej. Badacz stara się zadawać takie pytania, jakie skłonią respondenta do wielowątkowych dłuższych wypowiedzi” (Konecki 2000: 170). Technika ta pozwala na zindywidualizowane podejście do badanych (Przybyłowska 1978: 63). Odpowiada także problematyce badania. Zdaniem B. Budrowskiej, ,,metoda pogłębionego wywiadu zdaje się być bardziej użyteczną i trafną techniką przy badaniu zagadnień społecznych szczególnie intensywnie uwikłanych w stereotypy, normy, oczekiwania społeczne" (Budrowska 2000: 358). W badaniu wspominanej autorki dotyczącym postaw wobec macierzyństwa, w którym zastosowano zarówno kwestionariusz wypełniany przez respondentki jak i wywiad swobodny, okazało się, że badanym kobietom w bezpośredniej rozmowie łatwiej było na przykład przełamać tabu wyrażania negatywnych odczuć związanych z macierzyństwem (tamże). Badaczka zauważyła, że w sytuacji wywiadu łatwiej jest „uniknąć pułapki posługiwania się formułami zgodnymi ze standardem kulturowym" (tamże).

W związku z tym że przedmiotem zainteresowania były osobiste doświadczenia jednostek związane $\mathrm{z}$ rodzicielstwem (zachowania oraz towarzyszące im interpretacje), w badaniu zastosowano podejście biograficzne (Lutyński 1994: 309; Włodarek, Ziółkowski 1990: 4). Chociaż przeprowadzane wywiady nie miały charakteru wywiadów narracyjnych, to opierały się na dłuższych wypowiedziach badanych dotyczących wybranego fragmentu ich biografii, określonego obszaru aktywności - rodzicielstwa („,biografia tematyczna”), przełomowego momentu w ich życiu, jakim były narodziny dziecka (Włodarek, Ziółkowski 1990: 5). Zgodnie z założeniami metody biograficznej interesowała nas nie tyle „prawda”, fakty, co ich subiektywna interpretacja przez respondentów, będąca często idealizacją rzeczywistości, próbą racjonalizacji własnego życia i podejmowanych działań (tamże: 5-6).

Zdecydowano, że wywiad swobodny będzie przeprowadzany jednocześnie $\mathrm{z}$ obojgiem rodziców. Zastosowano tu technikę podwójnego wywiadu (Double Interview), w którym udział biorą dwie znające się osoby (Nicińska 2000: 40). Celem było skonfrontowanie ze sobą wypowiedzi kobiety i mężczyzny razem doświadczających rodzicielstwa, poznanie ich sposobu postrzegania, definiowa- 
nia, interpretowania narodzin dziecka, stawania się rodzicami, zmian, jakie się z tym wiążą. Jak stwierdza Janusz Sztumski, „wywiad zbiorowy stwarza okazję do tego, by uzyskać bardziej wiarygodne dane, ponieważ uczestnicy korygują i uzupełniają nawzajem swoje wypowiedzi" (Sztumski 2005: 162). Ponadto zaletą była możliwość bezpośredniej obserwacji partnerów w trakcie wywiadu, poznających nawzajem swoje poglądy dotyczące spraw, o których często wcześniej nie mieli okazji rozmawiać. Za decyzją o podwójnym wywiadzie przemawiały także względy praktyczne: brak czasu respondentów w związku z opieką nad małym dzieckiem i założenie, że jeśli będzie to jeden wywiad a nie dwa, chętniej zgodzą się wziąć w nim udział. Ponadto istniała obawa, że może udać się porozmawiać jedynie z jednym z partnerów, a drugi może unikać spotkania i w konsekwencji badanie nie zostanie zrealizowane (warunkiem było uzyskanie wypowiedzi obojga rodziców). A tak, jeśli jeden z rodziców wyraził zgodę na wywiad, sam zachęcał drugą osobę do uczestnictwa i gwarantował jej udział w badaniu. Przeprowadzono 20 wywiadów swobodnych z parami rodziców (w okresie czerwiec-wrzesień 2007 r.). Wywiady przeprowadzała autorka pracy w mieszkaniach respondentów. Najdłuższy z nich trwał 135 minut, najkrótszy - 40 minut. Średni czas trwania wywiadu wyniósł 70 minut.

Drugą zastosowaną jakościową techniką badawczą były zogniskowane wywiady grupowe (Focus Group Interview - FGI). „Ich zaletą, podobnie jak pozostałych procedur jakościowych, jest niewątpliwie możliwość wniknięcia w głąb poruszanych problemów. [...] Są one pomocne tam, gdzie zawodzą metody ilościowe, «ślizgające» się często po powierzchni zjawisk" (Dukaczewska-Nałęcz 1999: 159, 160). Jedna z definicji wywiadu „fokusowego” określa go jako „nieformalną dyskusję wśród wybranych osób na określony temat odwołującą się do konkretnych sytuacji znanych tym osobom" (Daniłowicz, Lisek-Michalska 2004: 14). W technice tej wykorzystuje się fakt, że wiele opinii, poglądów, postaw ludzkich kształtuje się w procesie interakcji z innymi ludźmi (Dukaczewska-Nałęcz 1999: 159, 160). W tej sterowanej przez moderatora dyskusji uczestnicy mają możliwość swobodnego wypowiadania się, a także „możliwość komentowania wypowiedzi innych, przekonywania, argumentowania czy kontrargumentowania" (Daniłowicz, Lisek-Michalska 2004: 15). Zaletą wywiadów fokusowych (w języku polskim funkcjonuje także takie określenie) jest właśnie dynamika grupy, wzajemne stymulowanie się do wypowiedzi uczestników, pozytywny wpływ innych na otwartość, aktywność i kreatywność jednostki.

Podczas gdy wywiady swobodne zorientowane były na uchwycenie indywidualnych doświadczeń jednostek, osobistych przeżyć, uzyskanie bardziej szczegółowych danych na temat zachowań badanych w rolach rodzicielskich, celem wywiadów fokusowych było poznanie „możliwie kompletnego (raczej zagregowanego niż indywidualnego) zakresu zachowań i postaw" przedstawicieli wybranej kategorii społecznej (Nicińska 2000: 39, 48). Zebrane w ten sposób informacje są, z założenia, bardziej powierzchowne niż w wywiadach pogłębionych 
(Maison 2000: 23). W zogniskowanych wywiadach grupowych nie podjęto zagadnienia zmian, jakie wywołuje zostanie rodzicem w życiu kobiety i mężczyzny oraz wzorów macierzyństwa i ojcostwa w rodzinach pochodzenia respondentów, które to kwestie wymagały pogłębionego badania $\mathrm{z}$ zastosowaniem wywiadu swobodnego. Z kolei w celu zbadania przekonań na temat kobiecości i męskości oraz macierzyństwa i ojcostwa uczestników wywiadów fokusowych zastosowano technikę projekcyjną: test niedokończonych zdań. Jej wykorzystanie miało ułatwić badanym zwerbalizowanie definicji ról płciowych i rodzicielskich. Ponadto, w związku z tym że uczestnicy najpierw samodzielnie tworzyli definicje, które następnie były przedmiotem dyskusji, pozwoliło to $\mathrm{z}$ jednej strony na zebranie niezależnych opinii badanych, $\mathrm{z}$ drugiej strony urozmaiciło przebieg spotkania oraz ożywiło dyskusję (Maison 2000: 146-148). Ponieważ grupy dyskusyjne były homogeniczne pod wieloma względami (wiek, wykształcenie, sytuacja rodzinna, aktywność zawodowa, miejsce zamieszkania), uczestnicy posługiwali się podobnymi kodami komunikacyjnymi, odwoływali się do tych samych środowiskowo uwarunkowanych, kolektywnych znaczeń, schematów interpretacyjnych itp. (Bohnsack 2004: 40, 43).

Na potrzeby badania w listopadzie 2007 roku zrealizowano cztery zogniskowane wywiady grupowe (Focus Group Interview - FGI) (sesja z ośmioma kobietami, sesja z ośmioma mężczyznami i po dwie sesje z udziałem czterech kobiet i czterech mężczyzn). Moderatorem była autorka pracy. Każdy wywiad trwał około dwóch godzin.

Zastosowanie techniki zogniskowanych wywiadów grupowych pozwoliło na uzupełnienie i wzbogacenie materiału zebranego za pomocą wywiadów pogłębionych. Dało możliwość skonfrontowania poglądów kobiet i mężczyzn reprezentujących wybraną kategorię społeczną na interesujący nas temat, odkrycia podobieństw i różnic $\mathrm{w}$ postrzeganiu przez nich ról kobiecych i męskich, w tym ról rodzicielskich, poznania racjonalizacji i argumentacji towarzyszących opiniom i zachowaniom badanych. W połączeniu te dwie techniki badawcze pozwoliły stwierdzić, na ile wybrani do badania młodzi wykształceni Polacy są podobni w realizowanych wzorach kobiecości i męskości oraz macierzyństwa i ojcostwa, a co ich w tym aspekcie różni.

W kolejnych rozdziałach, prezentujących wyniki badań, przytaczane są wypowiedzi badanych. W nawiasie za cytatem wypowiedzi umieszczona jest informacja o płci respondenta: $\mathrm{K}$ - kobieta, $\mathrm{M}$ - mężczyzna oraz numer wywiadu, na przykład K7. Jeśli w tekście pojawia się fragment dialogu pary rodziców, mamy informację o numerze wywiadu, na przykład W8. W przypadku wypowiedzi uczestników zogniskowanych wywiadów grupowych zaznaczono płeć i numer uczestnika oraz numer sesji, na przykład K5, FGI_3. Przy czym, w pierwszej sesji (FGI_1) uczestniczyły same kobiety, w drugiej (FGI_2) - sami mężczyźni, natomiast w sesji trzeciej i czwartej (FGI_3, FGI_4) udział brali przedstawiciele obu płci. Fragmenty grupowych dyskusji lub wywiadu 
w parach, które przytaczano by pokazać dialog, wymianę myśli między rozmówcami, ze względu na formę nie zostały włączone do ciągłego tekstu i przytaczane są pod danym akapitem. Imiona pojawiające się w wypowiedziach rozmówców zmieniono.

\subsection{Refleksje i uwagi badaczki}

Na podstawie wywiadów przeprowadzonych jednocześnie z obojgiem rodziców można sformułować pewne wnioski, pozwalające ocenić wartość takiego sposobu badania. Na wstępie należy zauważyć, że przebieg wywiadu (co dotyczy także wywiadów z jednostkami) zależał od uczestniczących w nich osób: od ich chęci i umiejętności opowiadania, nastawienia do samej sytuacji badania, dodatkowo - co ważne w przypadku wywiadu w diadzie - od wzajemnej relacji badanych (na przykład przyznawania sobie nawzajem prawa do posiadania odmiennego zdania, bycia w dobrej komitywie czy też „na wojennej stopie”). Świadczy o tym m.in. porównanie długości trwania wywiadów, a także analiza ich struktury. W niektórych przypadkach miały one formę narracji jednego lub na zmianę obojga uczestników, przerywanych co jakiś czas pytaniami badacza. W innych - osoba prowadząca wywiad musiała zadać wiele pytań, by uzyskać satysfakcjonujący materiał badawczy. W wywiadach z „rozmownymi” respondentami odnosiło się często wrażenie, że wywiad „sam się prowadzi” - partnerzy nawzajem „podrzucali” sobie tematy, starając się dać jak najpełniejszy obraz sytuacji. Pokazuje to poniższy fragment wywiadu:

B: A teraz państwo oboje pracujecie tak, czyli ten kontakt macie podobny, czas spędzany z dzieckiem?

K: No teraz wyrównały się obowiązki w stosunku do Krzysia nas obojga. Mamy opiekunkę, ja już pracuję półtora roku, pani przychodzi na ósmą do siedemnastej, ja już staram się być o siedemnastej w domu. No i że tak powiem...

M: Ale może kilka słów na temat opiekunki, bo też jest ważny jak gdyby etap w wychowywaniu dziecka, podjęcie decyzji, że swoje dziecko zostawiamy jakiejś obcej przypadkowej osobie.

K: Ale nie, może jeszcze słowo, dlaczego ja wróciłam do pracy. [W4]

W większości sytuacji badawczych zaobserwowano stymulujący wpływ jednego rozmówcy na drugiego - „wywołanego do odpowiedzi” przez partnera, czy „zmuszonego" do skomentowania jego wypowiedzi. Niekiedy badacz pozostawał zupełnie $\mathrm{z}$ boku, rozmowa toczyła się między uczestniczącymi w badaniu rodzicami, którzy poznawali wzajemnie swój sposób postrzegania narodzin dziecka w ich życiu, rozumienia macierzyństwa i ojcostwa. Jeżeli rodzinę w nowoczesnym 
społeczeństwie traktujemy jako negocjowaną relację, interakcję między jej członkami, w trakcie której uzgadniają oni znaczenia dotyczące ich ról, rodzinnych wydarzeń, codziennego życia, to tu „uzgadnianie perspektyw” zostało przeniesione na sytuację wywiadu, musiało zostać zwerbalizowane wobec stawianych przez badacza pytań. Okazywało się, że partnerzy często podzielali swój punkt widzenia, ale też zdarzały się sytuacje, w których jedna $\mathrm{z}$ osób była zdziwiona, wręcz zaskoczona wypowiedzią partnera - ,to ty tak to widzisz? To dla ciebie to znaczy zupełnie coś innego niż dla mnie?”. Te różnice respondenci starali się sobie wytłumaczyć, odwołując się na przykład do podziału płci, zaznaczając, że tak już jest, że kobiety i mężczyźni odczuwają, postrzegają, rozumieją pewne rzeczy inaczej. Wyjaśniali je także poprzez różne zaangażowanie, a dokładnie przez różnicę czasu spędzanego w domu z dzieckiem, co mogło przekładać się na inne doświadczanie rodzicielstwa.

Na otwartość i szczerość respondentów wpływ miała niewątpliwie atmosfera wywiadu, przeprowadzanego $\mathrm{w}$ ich domach, przypominającego towarzyską rozmowę między ludźmi pod wieloma względami do siebie podobnymi (przeprowadzająca wywiady badaczka należy do badanej kategorii społecznej). Obecność partnera sprawiała, że ewentualny stres związany z sytuacją wywiadu był mniejszy. Dzięki temu rozmówcy czuli się swobodnie.

W świetle przeprowadzonego badania znaczenia nabiera terapeutyczna funkcja socjologicznego wywiadu, który w sytuacji konfrontowania stanowisk partnerów stawał się swego rodzaju małżeńską terapią. Takie odczucie mieli sami badani, o czym świadczy na przykład komentarz jednej z kobiet do wypowiedzi męża, wyrażającego niezadowolenie z konieczności ciągłego odwiedzania z dzieckiem jednych i drugich dziadków i w związku z tym braku wolnych weekendów: „Teraz tu Tomek wyleje wszystkie bóle. To jest jak terapia" [K1]. Pokazuje to także poniższy fragment rozmowy jednej z par, poświęcony nieporozumieniom między partnerami:

K: Mnie brakuje troszkę zrozumienia na przykład tej drugiej strony.

M: No już się tutaj nie uwewnętrzniaj. Pani jest socjologiem nie psychologiem i nic ci nie pomoże, jak coś opowiesz.

K: Nie o to mi chodzi, ale ktoś kto może obiektywnie spojrzeć przy okazji robienia badań. [W5]

Można przypuszczać (choć chociażby cytowana wyżej wypowiedź na to nie wskazuje), że wspólny wywiad sprawił, że partnerzy starali się idealizować związek, po pierwsze ze względu na osobę badacza (starania, by „dobrze wypaść” dotyczą także respondentów w wywiadach indywidualnych). Tym bardziej że w polskiej kulturze wciąż powszechne jest przekonanie, że rodzinne problemy to sprawy prywatne i nie powinno się z nimi dzielić z obcymi osobami. Po dru- 
gie, znaczenie miała obecność partnera i możliwość urażenia go, czy zrobienia mu przykrości przez ujawnienie jakichś faktów, które mogłyby przedstawić go w niekorzystnym świetle. $Z$ wypowiedzi badanych wynikało, że ,poprawne politycznie" są partnerskie relacje, a zatem nie wypada przyznać się, że mężczyzna niewiele $\mathrm{w}$ domu robi, czy że niezbyt angażuje się w opiekę nad dzieckiem. $\mathrm{W}$ związku z tym, pojawiały się w wypowiedziach, kobiet przede wszystkim, zapewnienia, że „mąż jest bardzo zaangażowany”, „muszę go pochwalić, bo bardzo mi pomaga, na przykład w porównaniu z mężami koleżanek" itp. (Z drugiej jednak strony, mężczyźni słabo uczestniczący w życiu rodzinnym, głównie ze względu na pracę zawodową, sami o tym mówili). Gdy przyjrzymy się wynikom badań przeprowadzanych na potrzeby pracy Nieodplatna praca kobiet, zobaczymy, że tam kobiety i mężczyźni „rozmijali się” znacznie w prezentowanych wersjach podziału obowiązków domowych: mężczyźni deklarowali, że robią dużo więcej niż dostrzegały to kobiety (Titkow i in. 2004b: 111). Nie można wykluczyć, że osobne wywiady z młodymi rodzicami przyniosłyby nieco inny obraz ich rodzin i wzajemnej relacji.

$\mathrm{W}$ odniesieniu do zrealizowanych zogniskowanych wywiadów grupowych nasuwają się następujące refleksje. Homogeniczność (pod wieloma względami) grup dyskusyjnych sprawiła, że uczestnicy szybko się integrowali, chętnie współpracowali i wywiady przebiegały w dobrej atmosferze sprzyjającej otwartości uczestników. Swoiste poczucie wspólnoty pojawiło się w grupach fokusowych składających się z uczestników jednej płci. W wypowiedziach kobiet oraz mężczyzn dyskutujących w swoim gronie przejawiało się myślenie w kategoriach „my - oni”. Rozmówcy, mając poczucie, że rozmawiają z osobami będącymi „po tej samej stronie” (w związku z byciem kobietą/mężczyzną, matką/ojcem) pozwalali sobie na krytyczne komentarze dotyczące przedstawicieli płci przeciwnej i z reguły znajdowali poparcie (werbalne i niewerbalne) dla swoich poglądów w pozostałych osobach. Pokazują to poniższe fragmenty dyskusji:

K5: Dzieci miały wtedy chyba półtora, nawet nie, dzieci miały miesiąc. No więc u mnie było tak, że budziły się co dwie godziny, z zegarkiem w ręku, to były wcześniaki, trzeba było przy nich czuwać po karmieniu, nosić je po czterdzieści minut, żeby im się odbiło, miały bezdechy, więc to był dla mnie koszmar. Właściwie pierwszy rok taki był. No i poświęcenie matki. Ja cały czas wstająca, mąż, no wiadomo, pracował. No to ja już mówię, niech nie wstaje, no bo do pracy, żeby był wyspany. I dzieci miały miesiąc, mąż wyjechał sobie na wycieczkę z pracy na Kubę, no bo jak to, nie wyjechać. A ja zostałam z tymi dziećmi. Dobrze, że mam taką mamę, że przyjechała do mnie i po prostu nocowała, bo ja nie wiem jakbym sobie sama dała radę.

K6: Chyba bym go udusiła.

K5: To jest właśnie odpowiedzialność kobiet i mężczyzn. [FGI_1] 
M: A macie, odczuwacie, doświadczacie panowie czegoś takiego, że inne oczekiwania są wam stawiane niż kobietom?

M8: Tak. Ja najbardziej lubię stwierdzenie „się popsuło”. (śmiech pozostałych)

M2: Ja tak samo.

M8: „Się popsuło”. Cokolwiek by to nie było. Nie da się chodzić, bo coś tam, bo nie ma śrubokręta, czy coś.

M3: Ja wtedy mówię „to się zrobi kiedyś”. (śmiech pozostałych)

M8: To jest dobra odpowiedź.

M1: Chyba, że samochód na skrzyżowaniu stoi na awaryjnych. [...] kobieta powinna być bardziej taka przewidywalna. Nie wszystkie decyzje są takie całkowicie racjonalne. Że jeżeli będzie się czegoś używać wbrew zasadom tego urządzenia, można to popsuć.

M8: „Się popsuło”.

M1: A później „się popsuło”, na przykład. A to jest duży problem, bo dużą część czasu trzeba, zamiast zajmować się dzieckiem, trzeba siedzieć i naprawiać.

M5: Kobiety są roztargnione.

M8: Taki ich urok, dlatego trzeba być wyrozumiałym. [FGI_2]

Świadczą o tym także na przykład określenia zebrane za pomocą testu niedokończonych zdań, dotyczące kobiecości i męskości. Wśród charakterystyk mężczyzn tworzonych przez same panie znalazło się na przykład takie określenie jak: „Mężczyzna jest nieraz okropnym nieokrzesanym samcem”. Z kolei w grupie samych panów kobiety określono jako „przewrażliwione”. Tego typu stwierdzenia nie pojawiły się w fokusach mieszanych, w których uczestniczyła taka sama liczba kobiet i mężczyzn. Fakt naprzemiennego siedzenia przy stole uczestniczek i uczestników w trakcie tych wywiadów mógł mieć wpływ na ich bardziej koncyliacyjny charakter i trudność w ewentualnym tworzeniu wspólnych - kobiecych i męskich - frontów.

Podobieństwo uczestników zogniskowanych wywiadów grupowych oraz interesująca ich i bliska im problematyka badania (młodzi rodzice chętnie mówią o swoich dzieciach i wszystkim, co z dziećmi związane) sprzyjało występowaniu tak cennych w fokusach efektów grupowych (Malinowski 2004: 72-73). Badani zachęcali się nawzajem do udziału w dyskusji, komentowania wypowiedzi innych i przedstawiania swoich doświadczeń i poglądów (efekt stymulacji). Reagowali spontanicznie, o czym świadczy język i używane przez nich sformułowania czy skróty myślowe, których prawdopodobnie unikaliby w zaplanowanej, bardziej 
kontrolowanej i przemyślanej wypowiedzi (efekt spontaniczności). Pokazują to poniższe fragmenty grupowych dyskusji:

K4: Ja myślę, że nie każdy jest stworzony do tego, żeby być ojcem, czy matką, bo oczywiście to jest najprostsze, prawda...

K3: A jakie przyjemne (śmiech). [FGI_1]

M: Ale czy, żeby być „prawdziwym” mężczyzną, to ojcostwo jest potrzebne? Wzbogaca w jakiś sposób?

M1: No oczywiście.

M8: Siwe włosy. (śmiech)

M3: Portfel chudszy.

M6: Tatusiowi brzuszek rośnie. [FGI_2]

K4: [...] po prostu wiem, że mój mąż zapewni po prostu czas rewelacyjnie dziecku. Wiadomo, że on, to znaczy on na pewno, jedyne co to zawsze mówi, ,jejku, jak ja mam się znowu bawić jakimiś księżniczkami, lalkami..."

M1: To jest masakra.

K4: „Po prostu to jest najgorsze dla mnie, co może być”. I rzeczywiście mój mąż w ogóle nie bawi się lalkami, tylko zawsze są zajęcia, zabawy zupełnie inne.[FGI_3]

K1: [...] Czyli mężczyzna ma dziecko - odpowiedzialny ma być. Nic więcej. (śmiech)

M: Co panowie na to?

M3: Ha, odpowiedzialność. No w tym momencie już taka konkretna odpowiedzialność, nie od czasu do czasu, ale taki etap, że dokręcamy korbę, że tak powiem, i już...

K4: I koniec imprezy.

M3: No, mówiąc delikatnie. [FGI_4]

Uczestnicy czuli się komfortowo i swobodnie w towarzystwie podobnych do siebie osób, mających w wielu kwestiach takie same jak oni poglądy i doświadczenia (efekt zwiększonego poczucia bezpieczeństwa). Wypowiedź jednej osoby wywoływała określone skojarzenia, komentarze, odczucia pozostałych (efekt kuli śnieżnej). W rezultacie dyskusji, współdziałania i konfrontacji zebrano materiał, „będący czymś więcej niż prostą sumą efektów działania poszczególnych osób”, nie do uzyskania $\mathrm{w}$ indywidualnych wywiadach $\mathrm{z}$ tymi samymi osobami (efekt synergii) (Malinowski 2004: 73). 
Podczas realizacji zogniskowanych wywiadów grupowych zaobserwowano także negatywny wpływ grupy na uczestników, jak trudność w prezentowaniu odosobnionego stanowiska, różnego od poglądów pozostałych. Dostrzec to można było m.in. w jednej z dyskusji, w której uczestniczka opowiadająca o kobiecie decydującej się na nieposiadanie dziecka i wyrażająca zrozumienie dla jej decyzji musiała zmierzyć się z pozostałymi osobami, przekonującymi ją o istnieniu „naturalnej" potrzeby macierzyństwa. Można było odnieść wrażenie, że uczestnicy niekiedy starali się nie tyle dyskutować o różnych możliwych poglądach na określoną kwestię, co wypracować wspólne stanowisko poprzez eliminowanie - ignorowanie, zbywanie, traktowanie jako nieprawdopodobnych itp., poglądów z nim niezgodnych.

$\mathrm{Na}$ koniec warto wspomnieć jeszcze o osobistym doświadczeniu badaczki, które zdaniem F. Znanieckiego należy uznawać za mające taką samą obiektywną ważność jak materiał zebrany w procesie badawczym (Znaniecki 2008: 187). Tym bardziej, że socjolog skłonny jest do poddawania refleksji i analizowania tego, czego sam doświadcza. Zostanie mamą i doświadczenie rodzicielstwa przez autorkę pozwoliły jej zdaniem na lepszą interpretację i zrozumienie perspektywy badanych, tym bardziej że sama należy do objętej badaniem kategorii społecznej. 


\section{Rozdział 6. Kobiecość i męskość w świadomości młodych wykształconych Polaków}

\subsection{Sposób definiowania kobiecości i męskości przez uczestników badania}

Przedmiotem badania są wzory rodzicielstwa młodych wykształconych Polaków, jednak macierzyństwa i ojcostwa nie da się analizować w oderwaniu od kobiecości i męskości. Role rodzicielskie stanowią istotny element ról płciowych. Przekonania na temat cech, predyspozycji, zachowań właściwych dla każdej z płci determinują sposób postrzegania i realizowania macierzyństwa i ojcostwa.

O charakterystykę kobiecości i męskości poproszono zarówno uczestników wywiadów fokusowych, jak i respondentów w wywiadach swobodnych. W związku z inną techniką badania sposobu definiowania kobiecości i męskości zastosowaną w obu przypadkach, mającą wpływ na uzyskane rezultaty, wyniki zostały omówione kolejno, z uwzględnieniem rodzaju wywiadu.

$\mathrm{W}$ zogniskowanych wywiadach grupowych badani dokonywali charakterystyki płci poprzez dokończenie zdań: „Kobieta jest...”, „Kobieta powinna być...”, „Mężczyzna jest...”, „Mężczyzna powinien być...”. Wykorzystanie takiej techniki miało na celu odtworzenie stereotypu kobiecości i męskości w wymiarze deskryptywnym oraz normatywnym. Poznajemy tu zatem środowiskowy model kobiecości i męskości. W żadnej z dyskusji grupowych nie „zbuntowano się" przeciwko konieczności takiego stereotypowego - a więc uproszczonego, uogólnionego - ujęcia każdej z płci, podczas gdy od takich generalizacji uciekała część respondentów w wywiadach $\mathrm{z}$ parami rodziców.

$\mathrm{W}$ technice niedokończonych zdań w zogniskowanych wywiadach grupowych kobiety i mężczyzn opisywano za pomocą cech bądź ról społecznych (tabela 3). Odpowiedzi badanych uporządkowano według płci ich autorów, co pozwala poznać wizerunki kobiet i mężczyzn wyobrażane przez przedstawicieli danej płci oraz płci przeciwnej.

$\mathrm{Na}$ liście „kobiecych” właściwości („Kobieta jest...) stworzonej przez uczestniczki badania znalazły się takie stereotypowe cechy osobowości, jak: opiekuńczość, czułość, wrażliwość, delikatność, ciepło, oraz cechy wyglądu: piękna, ładna, zadbana. Wskazywano także typowe role pełnione przez kobiety: matka (jedna z badanych podkreśliła, że to najważniejsza rola życiowa, poprzez określenie ,przede wszystkim matka”), opiekunka (nie tylko dzieci, ale całej rodziny), „osoba zajmująca się głównie pielęgnacją dzieci”, ,szyja domu”. Wśród pozostałych odpowiedzi dwa razy pojawiło się stwierdzenie, że kobieta jest twórcza, poza tym: pracowita, zabiegana, wesoła i pogodna. 
Tabela 3. Rodzaje określeń kończących zdania „Kobieta jest...”, „Kobieta powinna być...” z uwzględnieniem płci uczestników

\begin{tabular}{|c|c|c|}
\hline Określenie & Kobiety & Mężczyźni \\
\hline $\begin{array}{l}\text { Kobieta } \\
\text { jest }\end{array}$ & $\begin{array}{l}\text { twórcza (2) } \\
\text { opiekuńcza (2) } \\
\text { ładna, zadbana } \\
\text { ciepłem } \\
\text { czuła i wrażliwa } \\
\text { piękna } \\
\text { pracowita } \\
\text { zabiegana } \\
\text { delikatna, czuła } \\
\text { wesoła i pogodna } \\
\text { przede wszystkim matką } \\
\text { szyją domu } \\
\text { matką, żoną, kucharką itp. } \\
\text { opiekunką (siebie, męża, dziecka, } \\
\quad \text { uczuć) } \\
\text { osobą, która zajmuje się głównie } \\
\quad \text { pielęgnacją dzieci }\end{array}$ & $\begin{array}{l}\text { przewrażliwiona (2) } \\
\text { szyją, na której obsadzona jest głowa } \\
\text { bardziej sentymentalna aniżeli } \\
\quad \text { rozważna, przewidująca } \\
\text { pracowita } \\
\text { nadgorliwa } \\
\text { piękna } \\
\text { kobieca } \\
\text { matką, żoną } \\
\text { wsparciem dla mężczyzny (męża) } \\
\text { delikatna } \\
\text { towarzyszką życia } \\
\text { opiekuńcza } \\
\text { wspaniałą matką } \\
\text { eteryczna }\end{array}$ \\
\hline $\begin{array}{l}\text { Kobieta } \\
\text { powinna być }\end{array}$ & $\begin{array}{l}\text { opiekuńcza (3) } \\
\text { (dobrą) matką i żoną (2) } \\
\text { ciepła (2) } \\
\text { rodzinna (2) } \\
\text { bardziej szalona } \\
\text { zmysłowa i seksowna } \\
\text { radosna i zdecydowana } \\
\text { wszechstronna } \\
\text { Szczera } \\
\text { silna i cierpliwa } \\
\text { kreatywna } \\
\text { osobą, która wprowadza harmonię } \\
\quad \text { w domu } \\
\text { fascynująca } \\
\text { kobieca, ale nie pokorna }\end{array}$ & $\begin{array}{l}\text { opiekuńcza (5) } \\
\text { wyrozumiała (2) } \\
\text { osobą zapobiegawczą } \\
\text { czujną i troskliwą matką-żoną } \\
\text { zdyscyplinowana } \\
\text { posłuszna } \\
\text { dobrą matką } \\
\text { czuła } \\
\text { kochającą matką i żoną } \\
\text { przyjacielem } \\
\text { gotowa na wszystko } \\
\text { matką raz w życiu }\end{array}$ \\
\hline
\end{tabular}

Źródło: Opracowanie własne.

Obraz kobiety stworzony przez mężczyzn biorących udział w grupowych wywiadach wydaje się jeszcze bardziej stereotypowy. Poza cechami, które wymieniły uczestniczki badania, znalazły się takie określenia opisujące kobiety, jak: przewrażliwiona, bardziej sentymentalna niż rozważna i przewidująca, nadgorliwa, kobieca, eteryczna. Ponadto, obok wskazania roli matki, respondenci zwracali uwagę na role pełnione przez kobietę wobec mężczyzny, a mianowicie: bycie żoną, towarzyszką życia, „szyją, na której obsadzona jest głowa” oraz wspar- 
ciem. Ta ostatnia rola $\mathrm{w}$ tradycyjnym stereotypie przypisywana jest mężczyznom, a zatem pojawienie jej się w kobiecej charakterystyce może być interpretowane jako przyznanie mężczyznom prawa do „słabości” i potrzeby posiadania podpory w osobie partnerki.

Analiza normatywnego stereotypu kobiety („Kobieta powinna być...”) także pokazuje trwałość cech i ról tradycyjnie przypisywanych żeńskiej płci, odnoszących się do jej ,podstawowej” aktywności w sferze prywatnej. Zarówno uczestniczki badania, jak i mężczyźni biorący udział w grupowych dyskusjach wskazywali przede wszystkim na oczekiwaną opiekuńczość kobiet, bycie matką, a także żoną, czy ogólniej bycie „rodzinną osobą”, a zatem zorientowaną przede wszystkim na rodzinę i traktującą ją jako priorytet w życiu. Obraz ten dopełniały takie stereotypowe cechy, jak ciepło, troskliwość, czułość, ale także zapobiegawczość i czujność (niezbędne w opiece nad dzieckiem) oraz wyrozumiałość, wskazywana przez mężczyzn, konieczna do pełnienia przez kobietę roli „osoby, która wprowadza harmonię w domu", jak określiła ją jedna z badanych. Przypomnijmy, że tradycyjny wizerunek kobiety czyni ją odpowiedzialną za relacje interpersonalne w rodzinie $\mathrm{i}$ „rodzinną atmosferę”, co zresztą zauważyły uczestniczki jednego z fokusów:

K7: Zawsze tak było. Zawsze tak było. Kobieta zawsze była kimś, kto stwarza ognisko takie, dom, ciepło...

K8: Atmosferę. [FGI_1]

Ponadto mężczyźni oczekiwali od kobiet zdyscyplinowania i posłuszeństwa oraz „,gotowości na wszystko”, co jest wyrazem preferowania patriarchalnej relacji płci, opartej na dominacji - podporządkowaniu. Na liście pożądanych kobiecych właściwości stworzonej przez uczestniczki wywiadów fokusowych znalazły się z kolei cechy niemieszczące się w stereotypowym wizerunku kobiety. Wśród nich takie, jak przypisywane mężczyznom: silna i zdecydowana, oraz „neutralne płciowo", takie jak: radosna, wszechstronna, kreatywna, szczera, bardziej szalona. Jako próbę przełamania stereotypu w kierunku androgyniczności można traktować określenie „kobieca, ale nie pokorna”. Pojawiła się tu także charakterystyka odwołująca się do stereotypu wyglądu kobiety, która zdaniem jednej z uczestniczek powinna być „zmysłowa i seksowna”.

Analiza wypowiedzi dotyczących męskiego wizerunku tak w wymiarze deskryptywnym, jak również normatywnym potwierdza częściowo obserwacje badaczy, że współczesny wizerunek mężczyzny jest w dużej mierze tradycyjny, stabilny (tabela 4). Widać to wyraźnie w określeniach użytych przez męską część uczestników wywiadów grupowych. Zarówno w ich zdaniach odnoszących się do tego, jaki mężczyzna jest, jak i tych mówiących o tym, jaki powinien być, pojawiały się takie „typowe” męskie cechy, jak: odpowiedzialność, zaradność, siła, twardość, stanowczość, „męskość”, praktyczność, oraz role: głowa rodziny, „filar rodziny”, oparcie czy wsparcie dla kobiety i rodziny, decydująca osoba w rodzinie. 
Tabela 4. Rodzaje określeń kończących zdania „Mężczyzna jest...”, „Mężczyzna powinien być...” z uwzględnieniem płci uczestników

\begin{tabular}{|c|c|c|}
\hline Określenie & Kobiety & Mężczyźni \\
\hline $\begin{array}{l}\text { Mężczyzna } \\
\text { jest }\end{array}$ & $\begin{array}{l}\text { bardziej niezależny niż kobieta } \\
\text { wsparciem } \\
\text { zapracowany, zawsze zmęczony } \\
\text { seksowny } \\
\text { opiekunem } \\
\text { podporą kobiety } \\
\text { nieraz okropnym nieokrzesanym } \\
\quad \text { samcem } \\
\text { wygodny } \\
\text { głową domu } \\
\text { odważny, potrafi wspierać rodzinę } \\
\text { twardy } \\
\text { osobą poważną i głową rodziny } \\
\text { bardzo potrzebny } \\
\text { osobą do zabaw z dziećmi } \\
\text { niezależny } \\
\text { na ogół nieodpowiedzialny }\end{array}$ & $\begin{array}{l}\text { głową rodziny (6) } \\
\text { filarem rodziny } \\
\text { bo jest } \\
\text { praktyczny } \\
\text { leniwy } \\
\text { cudowny } \\
\text { ok. } \\
\text { oparciem dla kobiety } \\
\text { męski } \\
\text { mądry } \\
\text { silny }\end{array}$ \\
\hline $\begin{array}{l}\text { Mężczyzna } \\
\text { powinien być }\end{array}$ & $\begin{array}{l}\text { opiekuńczy (2) } \\
\text { (bardzo) cierpliwy (2) } \\
\text { wsparciem } \\
\text { dobrym ojcem } \\
\text { pomysłowy } \\
\text { bardziej domyślny } \\
\text { wyrozumiały } \\
\text { twardy, męski } \\
\text { głową rodziny } \\
\text { czuły } \\
\text { dobrym ojcem i mężem } \\
\text { wzorem do naśladowania } \\
\text { czuły i twardy jednocześnie } \\
\text { osobą przy której cała rodzina czuje } \\
\quad \text { bezpieczeństwo } \\
\text { odpowiedzialny } \\
\text { silny }\end{array}$ & $\begin{array}{l}\text { odpowiedzialny (4) } \\
\text { opiekuńczy (3) } \\
\text { zaradny (2) } \\
\text { decydującą osobą w rodzinie } \\
\text { spokojny } \\
\text { wyrozumiały } \\
\text { twardy } \\
\text { wsparciem dla rodziny } \\
\text { stanowczy } \\
\text { głową rodziny }\end{array}$ \\
\hline
\end{tabular}

Źródło: Opracowanie własne.

Jedynym przejawem nowoczesnego postrzegania mężczyzn przez nich samych jest wskazanie opiekuńczości jako pożądanej cechy. Jej brak w opisowym stereotypie i określenie w kategoriach powinności można interpretować jako świadomość uczestników badania dotyczącą zmiany oczekiwań wobec męskiej płci i pojawienia się nowego wizerunku męskości. Można to również traktować jako akceptację androgyniczności i przejawiania przez jednostkę 
cech tradycyjnie przypisanych drugiej płci, a także jako przekonanie o zacieraniu się różnic między rolą kobiecą i męską, na co wskazują komentarze badanych:

M7: Zresztą to widać nawet po tym, co tu jest napisane. Powinien być opiekuńczy - razy dwa,
opiekuńcza - razy dwa. Tak, że widać jest, że przynajmniej mamy takie wyobrażenie, żeby
te role się przenikały. Tak często jest. To nie jest tylko rolą, nie wiem, żony, matki, żeby być
opiekuńczy, ale od ojca, męża, no też powinien być, nie. Itd., itd. Właściwie, tak naprawdę
do każdej z tych cech to można by przypisać, nie, że byłoby idealnie, gdyby się przenikało...

M8: Też tak myślę.

M7: ...żeby jedna i druga strona się potrafiła takimi cechami się wykazać, niewątpliwie. [FGI_2]

Wizerunek mężczyzny, stworzony na podstawie wypowiedzi uczestniczek badania, także w znacznej mierze odpowiada tradycyjnej definicji męskości, choć pojawiają się tu - również w wymiarze normatywnym - elementy nowoczesnego modelu. Zdaniem kobiet, mężczyzna jest, zgodnie z konserwatywnym ujęciem, głową domu, wsparciem i podporą kobiety, jest odważny, twardy i niezależny. Na jego obraz składają się także takie negatywne w swej wymowie charakterystyki, jak: „,nieraz okropny, nieokrzesany samiec”, „na ogół nieodpowiedzialny”, „wygodny” (czyli prawdopodobnie dążący do zapewnienia sobie jak najwygodniejszego życia, na przykład poprzez unikanie uciążliwych domowych obowiązków). Jedna z uczestniczek określiła mężczyznę jako „osobę do zabaw z dziećmi”, wskazując tym samym na podział ról rodzicielskich, powszechny w polskich rodzinach, w których to matka odpowiada za większość czynności pielęgnacyjno-opiekuńczych, a rola ojca sprowadza się do dbania o materialny byt oraz organizowania zabawy dziecku. Inne stwierdzenie „mężczyzna jest zapracowany, zawsze zmęczony" świadczy natomiast o tym, że jego rola ogranicza się niekiedy do pracy zawodowej, gdyż na aktywność rodzinną nie starcza mu sił. Jest to jednak przez część kobiet usprawiedliwiane jako efekt podziału ról, na co wskazywać może następujący komentarz jednej z uczestniczek: „Ale z drugiej strony, dziewczyny, ja na przykład wymagam tego od niego, żeby on zapracował na tą rodzinę. No sorry, ale jeżeli ja zajmuję się dziećmi i wychowuję, bo on cierpliwości podobno nie ma takiej jak ja, no to chociaż musi zapracować. [...] Na nim też spoczywa wielka odpowiedzialność, bo on wie, że on musi zarobić, po prostu musi i tyle, no" [K5, FGI_1]. Wśród niestereotypowych charakterystyk mężczyzny w wypowiedziach kobiet pojawiło się określenie „seksowny”, które w tradycyjnym modelu płci odnosi się do kobiet. Może to być przejaw wspominanej „feminizacji męskiego ciała". Ponadto, według jednej z badanych, mężczyzna jest opiekunem, które to określenie (bez przydawki dopełniaczowej, na przykład opiekun dziecka) w odniesieniu do mężczyzn kojarzy się raczej z otaczaniem opieką całej rodziny, 
a zatem do wspominanej wcześniej roli „rodzinnego wsparcia” niż do analogicznej roli kobiecej: roli opiekunki, ściśle związanej, w społecznym przekonaniu, z rolą matki. Chociaż w dyskusji, jaka wywiązała się wokół stworzonych obrazów kobiecości i męskości, jedna z uczestniczek (być może sama autorka tego określenia) zinterpretowała je jako postulat, żeby mężczyzna ,trochę przejął naszych, znaczy naszych, no kobiety, takich cech" [K6, FGI_1].

Podobnie jak w przypadku wypowiedzi męskiej części badanych, także oczekiwania kobiet co do tego, jaki mężczyzna powinien być, odpowiadają bardziej niż charakterystyki opisowe nowoczesnemu modelowi płci. Pojawiają się tu bowiem takie nietypowe dla tradycyjnej męskości cechy jak: opiekuńczość, cierpliwość, czułość i wyrozumiałość oraz określenie wskazujące na pożądaną androgyniczność: czułość połączona z twardością. Pozostałe normatywne wskazania mieszczą się już w konserwatywnym sposobie definiowania płci, dotyczą bowiem bycia głową rodziny, ojcem i mężem oraz osobą wspierającą i zapewniającą bezpieczeństwo, a także odpowiedzialności, siły, twardości i męskości. W odniesieniu do roli rodzicielskiej kobiety wyraziły oczekiwanie, że mężczyzna będzie wzorem do naśladowania (co wskazuje na tradycyjny wychowawczy aspekt ojcostwa) oraz że będzie dobrym ojcem. Wokół ostatniego określenia w wywiadzie grupowym z samymi kobietami wywiązała się dyskusja, w której uczestniczki zauważyły, że pojawienie się tu przymiotnika „dobry” w odniesieniu do ojcostwa i jego brak (w charakterystykach tworzonych przez kobiety) w odniesieniu do matek, wskazuje na odmienność ról rodzicielskich. Pojawiły się opinie, że matka „z natury” jest dobra, czego nie można powiedzieć o ojcach.

K7: Mężczyzna powinien być dobrym ojcem, a kobieta, nie ma, że powinna być dobrą matką. Bo ona jest matką.

K1: Tak jakby się to rozumiało samo przez się.

K3: Bo ona wie, że ,jest”, a nie „powinna być”.

K8: To jest naturalne. Nie bierze się pod uwagę tego, że ona powinna być, ona po prostu jest.

K3: A facet - niektóry jest, niektóry nie jest.

K1: Ta rola jest naturalnie przypisana kobiecie, a facet jednak musi w tę rolę bardziej wejść.

K8: Jeden wejdzie, inny nie. [FGI_1]

Podsumowując, wyobrażenia kobiecości i męskości uczestników wywiadów grupowych, odtworzone za pomocą techniki projekcyjnej, odpowiadają raczej tradycyjnemu modelowi płci. Zauważali to sami badani: 
K2: Ja bym powiedziała, że to jest taki starodawny typ podzielenia mężczyzn i kobiet.

K3: Tak, tak.

K2: Że mężczyzna to głowa domu, która powinna być wsparciem, a kobieta to żona i matka, opiekunka. [FGI_3]

Komentarze towarzyszące prezentowanym wizerunkom płci pokazują z jednej strony, że respondentom trudno było uwolnić się od stereotypów płci, mimo że często zdawali sobie sprawę (czemu dawali wyraz), że jest to generalizacja, uproszczenie odbiegające od społecznej rzeczywistości - „To się tak głośno mówi po prostu o stereotypach" [M1, FGI_3]. Niektórzy z nich podkreślali, że „nie zawsze tak jest”, „to nie jest reguła”, „to zależy od cech charakteru przede wszystkim”, „to wszystko to jest indywidualne podejście każdego z nas". Zaznaczali, że ich samych, czy osób im znanych, to nie dotyczy. Kwestionowali kulturowe schematy, jak jeden z mężczyzn, który stwierdził: „Znaczy, też nie bardzo mi się podoba stereotyp, że mężczyzna powinien być głową rodziny. To chyba nie ma już, znaczy, nie powinno być czegoś takiego jak głowa rodziny, czyli osoba, która «ja i tylko ja rządzę», tak. Jest nas dwoje, mamy problem i siadamy, omawiamy, na zasadzie kompromisu ustalamy wspólną strategię działania" [M2, FGI_4]. W jednej z dyskusji podkreślano, że tradycyjny podział ról należy do przeszłości, że współczesne młode rodziny (do których badani zaliczali swoje rodziny) odchodzą od takiej specjalizacji i opierają się na partnerstwie:

M2: My tu mówimy o pewnych stereotypach. Ja mam takie wrażenie, że jest to związane z sytuacją pokoleniową. Pokolenie naszych ojców, matek i jeszcze wcześniejsze myśli właśnie w takim schemacie: matka, czyli osoba siedząca w domu, wychowująca dzieci...

K3: Gotująca.

M2: ...ojciec, czyli właśnie ten silny, ten, który ma zarabiać i utrzymywać rodzinę i jest czasem do zabawy z dziećmi. Natomiast myślę, że nasze pokolenie i pokolenia następne będą myślały już troszkę inaczej.

K3: Już myślą inaczej.

M1: Tak.

M2: Znaczy, ja myślę już trochę inaczej i mam wrażenie, że moi rówieśnicy myślą podobnie i to się będzie dalej przekształcało.

K3: To jest stereotyp takiej typowej chyba rodziny właśnie za czasów naszych rodziców, już chyba nie istnieje albo istnieje bardzo rzadko, tak mi się wydaje, z moich obserwacji. [FGI_4] 
Jednocześnie jednak pojawiały się opinie o braku zmiany kulturowej lub jej powolnym, niemal niezauważalnym postępowaniu. Część badanych zauważała, że podział cech i ról na kobiece i męskie odpowiada temu, jak jest w większości rodzin. Stwierdzano na przykład „A ja myślę, że mężczyźni idą do pracy i pozostawiają wszystko na głowie kobiecie. [...] tak na ogół jest” [K3, FGI_3]; „Tak, ale to się właśnie skłaniamy w kierunku stereotypu, który w dalszym ciągu funkcjonuje, może nie wszędzie, ale no jednak tak jest. Jeszcze w miastach to pół biedy, ale w mniejszych miastach, czy na wsiach to w dalszym ciągu" [M1, FGI_4]. Powyższe różnice poglądów młodych wykształconych Polaków wskazują na trudność w ustaleniu kulturowego modelu (nawet w odniesieniu do stosunkowo homogenicznej badanej zbiorowości), który badacz poznaje już zinterpretowany przez badanych na ich własny sposób, odwołujących się w tych interpretacjach do różnych osobistych wartości, ideałów, doświadczeń itp. Z drugiej strony, obecność wielu tradycyjnych elementów w charakterystykach kobiet i mężczyzn, pojawiających się niejako automatycznie w świadomości respondentów, wskazuje na ich trwałość, mimo deklarowanego przez wielu przekonania o ich nieaktualności. Należy pamiętać, że celem zastosowanej techniki projekcyjnej było właśnie uchwycenie stereotypów, sprowokowanie badanych do sięgnięcia po stereotypowe określenia odnoszące się do kobiecości i męskości.

Inaczej wyglądało badanie tej problematyki w wywiadach pogłębionych. Respondentom zadawano pytanie, czy dostrzegają jakieś specyficzne cechy różniące kobiety i mężczyzn, zakładając, że będą się tu oni odnosić w pierwszej kolejności do własnych doświadczeń, ewentualnie, że będą swoją (oraz swojego partnera/ partnerki) kobiecość i męskość konfrontować ze stereotypem. Do takiej konfrontacji skłaniano ich także bezpośrednio, prosząc o ustosunkowanie się do stereotypowych stwierdzeń, mówiących o „,czułych matkach” i „surowych ojcach”. Rzeczywiście, badani mówili przede wszystkim o realizowanych wzorach ról płciowych (tj. głównie posiadaniu określonych cech), ale też odwoływali się do kulturowych modeli płci, widząc związek pomiędzy nimi bądź go negując i kwestionując tym samym płciowe stereotypy. Pokazują to dwie poniższe wypowiedzi:

B: A właśnie, bo jest też taki stereotyp, że właśnie mama jest tą właśnie bardziej czułą osobą, a tata z kolei, no mamy ten stereotyp twardej ojcowskiej ręki, że ojciec ma być autorytetem, bardziej surowy, dyscyplinujący dziecko. Coś takiego dostrzegacie u siebie państwo?

K: Nie.

M: Nie, raczej nie.

K: Ja też potrafię krzyknąć na niego, nie wiem, czy nawet nie szybciej się zdenerwuję. To zależy...

M: Nie, nie mamy jakiegoś takiego rozróżnienia, że ja jestem bardziej surowy, a żona bardziej czuła, nie. [W7] 
B: Czy dostrzegacie jakieś cechy, które mają tylko kobiety i cechy, które mają tylko mężczyźni? Czy takie cechy przejawiają się w innej relacji z dzieckiem kobiety i mężczyzny?

M: Jeżeli chodzi o nas, to Ania na pewno ma więcej cierpliwości, pobłażliwości. [W8]

B: A czy dostrzegacie państwo jakieś typowo kobiece cechy i typowo męskie cechy, które różnią właśnie kobiety i mężczyzn, i które mogłyby się przejawiać na przykład w kontakcie z dzieckiem, czy innym wykonywaniu roli rodzica? Czy jest coś, co różni kobiety i mężczyzn?

M: Myślę, że cierpliwość. Kobiety są bardzo cierpliwe, faceci są bardziej zniecierpliwieni. No nie wiem, jak coś ...

K: ... to nerwy od razu. A ja jakoś spokojniej, ona broi, broi, no to broi, czy tam płacze, no po prostu płacze, a ty się denerwujesz. [W14]

Wśród badanych, z którymi przeprowadzono wywiady swobodne, można wyodrębnić trzy typy poglądów na temat kobiecości i męskości, różniące się podejściem do stereotypów płciowych. Pierwszy z nich - odpowiadający nowoczesnemu modelowi płci - kwestionuje istnienie specyficznych kobiecych i męskich cech. Respondenci mówili o trudności we wskazaniu różnic między płciami: „Raczej nie przychodzi mi nic do głowy” [K6]; „trudno jest znaleźć takie cechy, które są charakterystyczne dla kobiety i mężczyzny" [K3]. Pojawiły się tu także stwierdzenia, że takich różnic nie ma [M6]. Zauważano, że przejawianie przez nich - jako kobietę i mężczyznę - określonych cech nie oznacza, że tak samo jest w innych rodzinach. Podkreślano, że nie wszystkie kobiety i nie wszyscy mężczyźni przejawiają takie same cechy, a zatem nie zależą one od płci: „Mój mąż jest na przykład taki, ale w innym małżeństwie jest zupełnie odwrotnie i kobieta ma te cechy, które ja przypisywałam swojemu mężowi” [K3]; „A to też zależy właśnie, w naszym przypadku akurat tak się złożyło, ale są no może związki gdzie sytuacja wygląda właśnie zupełnie odmiennie” [K17]; ,[...] mnie się wydaje, że nie jest to zależne od płci. Znam takie małżeństwa, w których prym wiedzie kobieta, jest, nie wiem, strasznym autorytetem, cholerykiem, egzekwuje na siłę wszystko to co chce, a facet spokojny «dobrze, kochanie, jak chcesz, kochanie» itd." [M3]. Nienaturalności podziału cech na kobiece i męskie (a zatem jego stereotypowości - kulturowego charakteru) dowodzono także poprzez podkreślanie podobieństwa cech obojga partnerów: „my jesteśmy podobni w ogóle, [...] my jesteśmy tak samo czuli dla dziecka, [...], nie różnimy się pod tym względem” [M16]; „Znaczy, dla mnie to kobiety i mężczyźni mają cechy, które się pokrywają" [M9]. Jako wspólną cechę, bez względu na płeć, wymieniano czułość, wrażliwość i umiejętność okazywania uczuć (które według tradycyjnego modelu należą do specyfiki kobiet): „Akurat mój mąż jest taki bardzo wrażliwy i taki jest ciepły i na przykład nie ma tak, że on jest jakiś oschły dla dzieci. Nie. Tak samo je często przytula, całuje, zawsze się musi z nimi pocałować. Tak, że tu nie ma różnicy" [K4]. Respondenci nie byli zgodni co do tego, kto jest bardziej cierpliwy - w niektórych 
wywiadach wskazywano, że kobiety, w innych, że mężczyźni, a w części w ogóle cechy tej nie wskazywano jako „typowo” kobiecej czy męskiej. Część par odrzucała podział na surowego ojca i bardziej pobłażliwą matkę i podkreślała, że to kobieta pełni funkcję ,dyscyplinującą” ([K12], [K16]) lub że rola taka należy do obojga rodziców: „No nie wiem, w każdym razie uważam, że taki podział jest bezsensowny, w zasadzie konsekwencją powinni wykazywać się oboje rodzice w wychowaniu i podejmowaniu decyzji i nie sądzę, że ja mam tutaj być źródłem, no nie wiem, jakiś emocjonalnych wartości dla mojego dziecka, a, nie wiem, mój mąż źródłem jakiś wzorców dyscypliny, nie absolutnie nie" [K18]. W jednej z rodzin, w której istniała taka specjalizacja ról, uznano, że jest to „,kwestia charakterologiczna”, a nie płciowa: ,[...] gdybyś ty był osobą łagodną, a ja furiatem, to te role by się odwróciły... na przykład u naszych znajomych to jest odwrotnie, że to tata na wszystko pozwala, a mama zakazuje. U nas raczej, jeżeli już ktoś powie «nie» to raczej mąż, niż ja, ja na więcej jej pozwolę i ona więcej może zrobić niż jak jest z mężem” [K13]. Jak zauważył inny z respondentów, „,to wszystko zależy od ludzi”, od ich cech charakteru i predyspozycji, a także od tego, ,jak to w danym związku wygląda" [M17]. Pojawiły się opinie, że jakiekolwiek generalizacje nie mają sensu, bo kategorie kobiet i mężczyzn, matek i ojców są zbyt zróżnicowane i znaleźć wśród nich można skrajnie różne postawy: „Ale tego nie da się zamknąć w jakichś ramach, bo zarówno kobiety można w przekroju puścić od najbardziej czułej dla dziecka, do takiej matki, która urodziła dziecko z dwoma promilami alkoholu we krwi, a z drugiej strony nie można też zamknąć w jakichś małych ramach ojców, że oni są tylko twardzi [...] Bo są mężczyźni którzy są wrażliwi i potrafią się wcielić w rolę takiej matki. [...] Bo ogólnie to mówię, tutaj po stronie kobiet jest taka gama, po stronie mężczyzn jest taka gama i możemy skrajne zebrać i powiedzieć, o są totalnie różni, albo są identyczni” [M9]. Jedna z respondentek wyraziła zdecydowany sprzeciw wobec stereotypizacji ze względu na płeć, ograniczającej i krzywdzącej jednostki: „Ja jestem przeciwniczką postrzegania właśnie takiego przez płeć ludzi: «kobieta to jest właśnie niezdolna do tego i do tamtego», bo trzydzieści kobiet nie będzie zdolnych rzeczywiście, a się znajdzie trzydziesta pierwsza, która będzie zdolna" [K17].

Drugi typ przekonań na temat kobiecości i męskości - tradycyjny, opiera się na przekonaniu o istnieniu naturalnych różnic między kobietami i mężczyznami, bądź (ze względu na chęć uniknięcia określenia „naturalne”) różnic powszechnie występujących: „To myślę, że tego się nie da nie zauważyć i to mówię, jeżeli nie wynika to z jakiegoś tam schematu, czy nie ma też jakiegoś uzasadnienia, to na pewno wynika to ze statystyki. [...] tak na pewno jest statystycznie" [M11]. Podkreślano przy tym właśnie naturalność takiego podziału, a nie jego kulturowy - stereotypowy charakter: ,to nie wynika z jakiegoś tam stereotypu, tylko, znaczy to może rodzić stereotyp, tylko z cech charakteru i różnic między kobietą i mężczyzną" [M5]; „To też jest taki nie stereotyp, ale standard, że mimo wszystko matki są takie bardziej do przyklejenia się w którymś momencie" [K7]. W jednym 
z wywiadów pojawiły się określenia: „prawidłowości natury” [K19]; „dwa różnego rodzaju mechanizmy funkcjonowania mózgu" [M19]. Zauważano, że dzieci „wyczuwają", rozpoznają odmienność płci, co przejawia się w ich innym stosunku do matek i ojców, na przykład chętniej przytulają się do mamy, ale też starają się wykorzystać ich pobłażliwość, natomiast przed ojcem czują większy respekt.

Część osób przekonanych o istnieniu różnic płciowych nie potrafiło ich jednak nazwać, wyjaśniając tę trudność właśnie ich naturalnością, oczywistością: „Ja wierzę $\mathrm{w}$ te różnice psychologiczne między kobietami i mężczyznami, coś w tym na pewno jest [M8] - Intuicyjnie się je czuje, ale trudno je jakoś wymienić, zdefiniować [K8]”; ,Stąd te trudności w zdefiniowaniu, że to są pewne naturalne wzorce, które, no my przynajmniej traktujemy, jako prawidłowe i one nam leżą, pasują" [M15]. Jeden z respondentów, przekonany o innym sposobie przeżywania różnych sytuacji przez przedstawicieli obu płci, krytykował „narzucanie” mężczyznom takich samych wzorów odczuwania rodzicielstwa i relacji z dzieckiem, jakie cechują kobiety, traktując je jako próbę „,skobiecenia” mężczyzny: „Wydaje mi się, że to jest po prostu nie na miejscu, bo mężczyzna na pewno to, jeżeli on w ogóle ma w głowie, że to dziecko jest jego dzieckiem, jeśli chce je wychować, to on i tak tą więź z nim złapie na bazie normalnego życia, ale on nie może się «skobiecić» w swoich zachowaniach" [M19].

Jeżeli chodzi o wskazywane przez respondentów w wywiadach swobodnych różnice płciowe, stosunkowo najczęściej jako cechę typową dla kobiet wymieniano emocjonalność w opozycji do racjonalności mężczyzn. Zauważano, że kobiety, także w roli matek, kierują się przede wszystkim emocjami, co znajduje wyraz w przejmowaniu się wszystkim, „panikowaniu” oraz w podejmowaniu nieprzemyślanych decyzji: „Kobieta tak się «naprzejmuje»” [K20]; „Kobiety panikują bardzo często, podejmują decyzję pod wpływem jakichś tam impulsów, emocji, które nie są w danym momencie najlepsze" [M2]. To „przejmowanie się" przybiera niekiedy formę "martwienia się na zapas”, zastanawiania się „,co by było, gdyby”, szukania dziury w całym: „Myślę, że to też jest charakterystyczne dla kobiet, że mężczyźni nigdy nie wybiegają tak w przyszłość, co by było gdyby, a kobiety jednak mają takie tendencje do analizowania problemu" [K18]. $\mathrm{Z}$ emocjonalnością wiążą się także inne cechy wskazywane jako kobiece, takie jak: wrażliwość, czułość, czy też umiejętność okazywania czułości, „miękkość” przejawiająca się w częstym przytulaniu dziecka i mówieniu do niego ciepłym, łagodnym głosem [M5, K5], ale także pobłażliwość i mniejsza w porównaniu z mężczyzną stanowczość w stosunku do dziecka: matka pozwala dziecku na więcej „z nadmiaru miłości” [M8]. Ta „nieracjonalność” kobiet z jednej strony prowadzi do impulsywności - „Chyba tak w ogóle jest u kobiet, że mały bodziec potrafi wywołać poważną reakcję i są bardziej impulsywne” [M5]. Z drugiej strony przejawia się w bojaźliwości i lęku o dziecko [M8], [M11], w „trosce na paranoję zakrawającej” [K20]. Jedna z par emocjonalnością kobiet wyjaśniała ich 
niezdecydowanie i trudności w podejmowaniu decyzji [W20]. Jako kobiecą cechę traktowano również dbałość o szczegóły i przywiązywanie do nich wagi, podczas gdy dla mężczyzny nie mają one znaczenia: ,[...] kobiety są bardzo takie szczegółowe, zwracają uwagę na szczegóły i takie, a faceci jakoś tak lżej podchodzą do tego. O, na przykład sam fakt, jak ja ubieram Marysię, no to ja się zastanawiam, żeby jej skarpetki pasowały, żeby jej buty pasowały, itd., a jak ja bym zostawiła na przykład Roberta z Marysią, no to prawdopodobnie wyjąłby pierwsze spodenki, założyłby jej i luz, nie” [K9]; „Ja myślę, że kobiety są bardziej, zbyt szczegółowe w niektórych aspektach, [...] Na przykład czy szczepionkę podamy taką albo taką, albo tamtą, na pewno ja podchodzę do tego całkiem inaczej, bardziej ogólnie [...]" [M18].

Kobiety były określane także jako delikatne, co odnoszono do wyglądu kobiet, ale przede wszystkim sposobu zachowania, także wobec noworodka. W relacjach z innymi są one bardziej niż mężczyźni skłonne do kompromisów [M13] oraz komunikatywne, łatwiej nawiązują kontakty i mają większą umiejętność mówienia do dziecka „o niczym”, opowiadania im bajek itp.: „Kobieta jest istotą, która komunikuje się, mówi z przyjaciółką, jest wychowywana do tego, że się mówi. Facet ma być twardy, facet ma być małomówny, w związku z powyższym no ok., facet komunikuje, kobieta się dzieli, jeśli kobieta się dzieli, używa większej ilości słów, facet ma powiedzieć konkretnie..." [M6].

Wśród cech kojarzonych z męskością wymieniano przeciwstawną do kobiecej emocjonalności rozwagę, umiejętność zachowania spokoju, racjonalne podejmowanie decyzji: „Mężczyźni, mimo tego że są nerwowi, podchodzą do wszelkich problemów, jakie pojawiają się w kwestii wychowywania dziecka itd. na tym etapie, podchodzą bardzo spokojnie, rozważnie, zastanawiają się” [M2]; ,[mężczyzna jest] racjonalnie myślący, mniej rozemocjonowany” [K15]; „faceci tak racjonalizują, zadaniowo do problemu: trzeba rozwiązać" [K20]. Jeden z respondentów nazwał to „kierowaniem się logiką” [M1]. Ta „nie-emocjonalność” mężczyzn sprawia, że są oni bardziej odporni psychicznie w porównaniu z kobietami, „twardzi” [M11], lepiej radzą sobie z płaczem dziecka (w przeciwieństwie do matek, które muszą natychmiast zareagować) [M6]. Mężczyźni są postrzegani jako bardziej stanowczy wobec dzieci, bardziej wymagający i umiejący je zdyscyplinować, co wiązano m.in. z określonym tembrem głosu. Męską cechą jest także niechęć bądź nieumiejętność rozmawiania o uczuciach [K4]: „[...] ze mną trudniej będzie córce porozmawiać o emocjach jakichś tam, bo ja o swoich nie potrafię za bardzo też... W tej materii na pewno nie za bardzo sobie radzę...” [M20]. Zwrócono także uwagę na większą potrzebę niezależności mężczyzn w porównaniu z kobietami, która przejawia się na przykład w konieczności wygospodarowania czasu tylko dla siebie, braku zgody na totalne „oddanie” się dziecku: „Ja jednak takie coś [chwile samotności] dużo bardziej potrzebuję niż ona, ale to też jest chyba damsko-męska różnica, tak w ogóle" [M19]; „Mężczyźni chyba, chociaż trudno tu uogólniać, bardziej się chyba bronią przed tym, żeby wszystko podporządkować dziecku" [M8]. 
Na podstawie analizy wypowiedzi badanych można wyodrębnić także trzeci typ poglądów na temat kobiecości i męskości. Można określić go mianem mieszanego czy pośredniego, łączy on bowiem w sobie poglądy tradycyjne i nowoczesne. Reprezentowały go osoby, które niejako automatycznie odwoływały się do stereotypów płciowych i przekonania o istnieniu ,specjalizacji” kobiet i mężczyzn, ale miały problem, jak interpretować fakt, że cechy przejawiane przez nie i przez ich partnerów się w tym stereotypie nie mieszczą. Nie odważały się na zakwestionowanie kulturowego podziału płci, więc albo dokonywały jego modyfikacji, uznając, że ich cechy (bądź partnera) są typowe dla ich płci, albo traktowały siebie (bądź partnera) jako wyjątek potwierdzający regułę i czuły się w obowiązku ten stereotyp podtrzymywać. Pokazują to poniższe wypowiedzi:

„Nie wiem, czy my jesteśmy standardowi, no bo nie wiem, ja jestem cierpliwszy na pewno. Jestem cierpliwszy, akurat w naszym przypadku Ewa jest bardziej impulsywna, bardzo reaguje, mocno na mały bodziec. Ale to jest chyba w ogóle tak. Chyba tak w ogóle jest u kobiet" [M5]

M: Ja odbieram to tak, że u nas rola Asi to jest rola takiej osoby bardziej czułej w stosunku do Krzysia, a moja rola jest niby, niby podkreślam, tego takiego twardego taty, który...

K: ...który w rzeczywistości nie jest twardy, który tylko udaje twardego.

M: No, ale właśnie, rzecz polega na tym, że nawet jeśli się nie jest twardym, to trzeba w niektórych sytuacjach tego twardego udawać, po prostu inaczej nie można się zachować. Bo jak ten mały brzdąc się zorientuje, że naprawdę jest się słabym i miękkim, no to jest przekichane.

[W2]

Podsumowując, sposób rozumienia kobiecości i męskości uczestniczących w badaniu młodych wykształconych Polaków częściowo odpowiada tradycyjnemu modelowi płci, ale też częściowo go kwestionuje. Analiza przekonań uczestników badania daje podstawy do stwierdzenia istnienia nowoczesnego modelu oraz odpowiadającego mu (w związku z tym, że badani często odwoływali się do swoich rzeczywistych doświadczeń) zaczątkowego nowego wzoru płci. Różne podejścia badawcze zastosowane w wywiadach grupowych oraz wywiadach pogłębionych pokazują, że w grupie jednostka skłonna jest do generalizacji i stereotypów (chociaż mamy świadomość, że wpływ na to miała w dużej mierze wykorzystana technika, mająca na celu właśnie uchwycenie owych gotowych schematów w myśleniu o rolach płciowych). W sytuacji wywiadu swobodnego badani częściej odnosili się do własnych doświadczeń i indywidualizowali własną sytuację, siebie samych traktując jako wyjątkowe jednostki. Stąd w wypowiedziach tych raczej skłaniano się do kwestionowania kulturowych reguł dotyczących bycia kobietą/ mężczyzną. Można to także interpretować jako przejaw indywidualizacji, podmiotowości i refleksyjności, powodujących niechęć do przyjmowania bez zastrzeżeń „tradycyjnych” definicji i wzorów zachowań oraz dowód na to, że „role płci poddać można refleksji” (Behnke i in. 2004: 152). 


\subsection{Postrzeganie macierzyństwa i ojcostwa jako elementów roli kobiety i mężczyzny w świetle wypowiedzi respondentów}

$\mathrm{W}$ tradycyjnym modelu płci zakładano, że role rodzicielskie stanowią nieodłączny, konieczny element kobiecości i męskości. Macierzyństwo traktowano jako powołanie kobiet i ich pierwszoplanową, najważniejszą rolę. W przypadku mężczyzn także obowiązywał nakaz ojcostwa - spłodzenie potomstwa (przede wszystkim syna gwarantującego przedłużenie rodu) było dowodem i warunkiem męskości, obok zasadzenia drzewa i zbudowania domu. Jednak w związku z aktywnością mężczyzny w sferze publicznej nakaz ten nie był tak bezwzględny jak w przypadku kobiet. Biologiczna rola - rola reprodukcyjna stanowiła podstawę kobiecości i męskości w ich tradycyjnym znaczeniu.

W badaniu sposobu rozumienia i realizowania macierzyństwa i ojcostwa przez młodych wykształconych rodziców starano się ustalić, czy postrzegają oni bycie rodzicem jako immanentny, konieczny element roli kobiety/mężczyzny i traktują rodzicielstwo w kategoriach społecznego nakazu. Proszono m.in. o ustosunkowanie się do stwierdzenia, że „prawdziwa kobieta” to ta, która jest matką, że „prawdziwy” mężczyzna musi być ojcem. Pytano także o stosunek do dobrowolnie bezdzietnych jako odrzucających wymóg bycia matką/ojcem i pod tym względem reprezentujących nowoczesny wzór roli płciowej.

Jak się okazuje, także w powyższej kwestii badani bardzo różnili się poglądami. Reprezentowali zarówno stanowisko tradycyjne, jak i nowoczesne oraz opcje pośrednie. Pierwszy typ obejmował osoby, które kategorycznie odrzucały zjawisko dobrowolnej bezdzietności, traktując posiadanie dziecka jako coś naturalnego i normalnego. Mówiono tu o naturalnym popędzie do przedłużenia gatunku, czy naturalnym etapie życia człowieka: ,[...] na wszystko w życiu jest czas i to jest jakby no jeden chyba z popędów człowieka, tak, rodzina. No jest się w jakimś związku na tyle długo, że musi się to zwieńczyć potomkiem i to jest naturalne, to jest normalne. [...] normalna przyrodzona rola jest taka, że wychodzę za mąż, czy żenię się i jest potomek” [M11]; ,Ja myślę, że w ogóle w życiu wszystko ma swój czas. Jest czas na dorastanie, czas na naukę, czas na pracę i w tym wszystkim musi się znaleźć czas na macierzyństwo, na ojcostwo, na rodzicielstwo" [K8, FGI_1]. „Wydaje mi się to takie naturalne, że w życiu gdzieś tam przez moment się hula, a potem przychodzi taka faza na coś innego" [K7]. Przyjmowano przy tym, że każdy człowiek, bez wyjątku, dąży do posiadania potomstwa, nawet gdy sobie tej potrzeby nie uświadamia: „[...] ja mam wrażenie, że to podświadomość jakby jest w nas taka, że każdy do tego dąży, żeby mieć dom, rodzinę, dzieci, przekazać, nie wiem, geny dalej. W każdym z nas to siedzi” [M3, FGI_3]; „Myślę, że nawet ci, którzy nie chcą, w głębi to jednak chcą mieć, bo każdy chyba do tego dąży" [K3, FGI_4]. W wywiadach grupowych podkreślano, że dziecko nadaje życiu sens, cel, pozwala dorosnąć: 
M2: Ale z drugiej strony, no to jaki jest sens życia? Po to żyjemy, żeby mieć dzieci, tak, wychować i trwać pokoleniowo.

M4: Dokładnie. Po co żyjemy?

M2: Bo żyjemy po to, m.in., żeby dać coś z siebie komuś innemu, mam na myśli dzieci.

$[\ldots]$

K3: To tak naprawdę jest wtedy życie. [FGI_4]

K1: Każdy powinien doświadczyć tego.

K4: [...] doświadczyć tego uczucia, bo wydaje mi się, że to naprawdę wiele zmienia. Zupełnie inaczej się patrzy na świat.

K2: Dojrzewa się. Człowiek jest odpowiedzialny za kogoś.

K1: Dojrzewa się razem z dzieckiem. [FGI_3]

Pojawienie się dziecka traktowano jako naturalną konsekwencję założenia rodziny, niezbędną dla nadania małżeństwu sensu: „Cóż warte jest małżeństwo bez dziecka” [M4, FGI_3]; „[...] ile czasu można być samemu, w dwójkę? To staje się nie to że nudne, ale tak naprawdę trzeba mieć, to są kolejne bodźce do tego, żeby wbrew pozorom być razem. Nie oszukujmy się, życie razem bez dzieci, w pewnym momencie wpada się w pewnego rodzaju rutynę, a potem to dziecko dodaje nowych sił do tego związku” [M18]; „Bo myślę, że są osoby zorientowane na rodzinę i myślę, że my jesteśmy takimi osobami, że dla nas rodzina to jest jakby ten azymut $\mathrm{w}$ życiu. I w momencie, kiedy w takiej rodzinie nie ma dziecka to w tym momencie troszeczkę coś tu nie gra" [K20].

Wobec takich argumentów zjawisko dobrowolnej bezdzietności było traktowane przez część osób - zarówno kobiet jak i mężczyzn - jako „nienormalne”, „,niezdrowe”, czy nawet patologiczne [K2; M11; K\&M14]; „dla mnie to jest takie troszkę nienormalne, jeżeli ktoś stawia na karierę, to nie powinno, ja uważam, tak być" [K8, FGI_1]. Przy czym częściej krytykowano bezdzietne kobiety, wskazując na niekorzystne skutki braku macierzyństwa i zakładając tym samym, że dziecko jest niezbędne dla ich „,normalnego” funkcjonowania: „kobieta deklaruje, że no nie chce mieć dzieci, no jest to dla mnie nienormalne, no nie będę ukrywał" [M18]; ,[...] akurat u mnie w pracy, tak się złożyło, że jest kilka panien, to są już dziewczyny, no po trzydziestce, więc to już się robią starymi pannami, już widzę pewne zachowania, które nazwałbym jednak staropanieństwem. One dzieci nie mają i uważam, że im czegoś brakuje, no niewątpliwie” [M7, FGI_1]; „Znaczy ja uważam, że kobieta, która w pewnym wieku nie ma jeszcze dziecka, to dewocieje po prostu" [K1, FGI_1]. Wśród respondentek pojawiły się opinie, że niechęć do 
zostania matką dyskwalifikuje kobietę, kwestionuje jej kobiecość: „Prawdziwa kobieta czuje to, że chce być matką. Takie jest moje zdanie” [K4, FGI_4]; „Jak jestem w pracy i są kobiety, dziewczyny w moim wieku i mówią tylko o psach i kotach, które prowadzają pięć razy w miesiącu do weterynarza i obcinają im włosy i śpią z nimi, no to po prostu nie mogę tego słuchać. [...] co to za kobieta, która całą swoją miłość przelewa na psa albo na kota, no? Jeszcze mówi, że dzieci są wredne, brzydko pachną [...]" [K2]. Jedna z badanych wyraziła przypuszczenie, że brak dziecka spowoduje w przyszłości poczucie niespełnienia u kobiety [K3]. Mówiono o naturalnej potrzebie posiadania potomstwa przez kobiety, odwołując się do pojęcia instynktu macierzyńskiego, budzącego się w wyniku kontaktu z małym dzieckiem [M16]. Przekonanie, że każda kobieta pragnie zostać matką, bo „macierzyństwo jest wtopione w naturę kobiety”, tylko jedne uświadamiają to sobie wcześniej, inne później, wyraziły uczestniczki jednego z wywiadów grupowych:

$\mathrm{K} 1:[\ldots]$ ja gdzieś tak do trzeciego roku studiów absolutnie nie widziałam się w roli matki,
właśnie mówiłam „nie, ja do tego się nie urodziłam, nie mam do tego żadnych zupełnie pre-
dyspozycji i wolę nie mieć dzieci niż później być taką wyrodną matką”. I któryś dzień był po
prostu taki, że mi się odmieniło. To chyba rzeczywiście trzeba po prostu...

K3: Dorosnąć.

K2: Poczuć po prostu.

K1: [...] faktycznie, tak jak mi wszyscy mówili ,poczujesz to, dojrzejesz do tego”...

K8: Tak.

K1: [...] co z tego, że koleżanki, koledzy już tam zakładają rodziny, już mają dzieci, poczujesz w pewnym momencie, że tego chcesz". I tak było.

K3: I cię trafiło. [FGI_1]

Niektóre kobiety wspominały o wyjątkowym, niesamowitym, niemal mistycznym kobiecym doświadczeniu ciąży i porodu: „Czy ja się poczułam bardziej kobieca? Chyba tak. Dla mnie, ja osobiście sobie nie wyobrażam, że już nie urodzę dziecka, myślę, że jeszcze urodzę. Dla mnie właśnie w ogóle ten moment powstawania tego dzieciaka, to jest dla mnie coś takiego zupełnie ponad, coś niesamowitego i ta bliskość z takim malusieńkim dzieckiem, karmienie piersią, to jest dla mnie takie ekstatyczne wręcz. Takie odczucie niesamowicie pozytywne. Wiesz, w tym sensie na pewno tak, na pewno tak. Poczułam się spełniona, znaczy nie o to chodzi, spełniona, czy niespełniona, tylko taka, to jest coś takiego bardzo fajnego” [K4]. Jedna z nich przyrównała poród do inicjacji: „Ciąża może ma coś takiego w sobie, że fajnie jak się chodzi z tym brzuchem, to jest 
takie niepowtarzalne, że to dziecko się rozwija i daje się życie, i przechodzi się ten poród, i jest się później, ten poród jest prawie jak inicjacja, jest się w grupie takich kobiet, które już to mają za sobą, jest się też społecznie, znaczy tak przez otoczenie człowiek inaczej jest postrzegany, jako, nie wiem, dojrzalszy, odpowiedzialniejszy, coś tam takiego... [...] dotknęłam pewnej tajemnicy, której być może inni nie dotykają" [K6].

Z powyższych wypowiedzi badanych wynika, że w społecznej świadomości funkcjonuje przede wszystkim nakaz macierzyństwa (nie rodzicielstwa w ogóle) i krytyce poddawane są przede wszystkim bezdzietne kobiety. Tylko jeden z badanych ojców zwrócił uwagę, że także w przypadku mężczyzn posiadanie dziecka jest traktowane jako konieczny element jego roli: „Znaczy na podstawie tylko tego, co ja czułem będąc ojcem, to na pewno jest jakieś potwierdzenie swojej męskości, no bo skoro spłodziłeś dziecko to znaczy, że dobrze tę rolę pewną wypełniłeś. Jest coś takiego, takie potwierdzenie. Na pewno. No jakbym nie mógł mieć dzieci, to może bym się gorzej czuł psychicznie na przykład, prawda? Miałbym jakiś problem w sobie, prawda? A nie mam, mam dzieci, więc wszystko jest ok. Tak człowiek sobie myśli" [M4].

O naturalności potrzeby posiadania dziecka miał zdaniem badanych obu płci świadczyć fakt, że osoby podejmujące decyzję o pozostaniu bezdzietnym „na pewno" potem będą tego żałować, ich życie będzie puste i smutne. A zatem ich decyzja nie jest tak naprawę ,świadoma i przemyślana”: „To na razie się wydaje, że jest świadome, ale to po prostu nie przyszedł czas, gdzieś gnają za czymś, nie wiem, za jakimś pieniądzem, za karierą, jak tego nie nazwiemy, a później się mogą z przysłowiową ręką w nocniku obudzić. [...] Wielu deklaruje, że jest ateistami, a później wzywa księdza, nie" [M7, FGI_2]. Przywoływano przykłady sfrustrowanych, samotnych kobiet, które zajęte karierą zawodową przegapiły moment, by zostać matką, a czasu nie da się przecież cofnąć: „Ja, od kiedy jestem matką i patrzę na kobiety starsze i nie mają dzieci, to zawsze patrząc na nie, pojawia mi się taka myśl właśnie, że bardzo dużo straciły i często nawet mi się wydaje, że na pewno tej decyzji żałują, że nie są matkami, chociaż nie do końca może to jest prawda, ale coś takiego mi się pojawia" [K15]. Mówiono o współczuciu, nawet litości dla osób bezdzietnych, pozbawiających się radości i sensu życia płynących z posiadania potomstwa: „Ale też później jacy oni są nieszczęśliwi po iluś tam, jak już przyjdzie moment, że nie można" [K6, FGI_1]. W wypowiedziach badanych pojawiały się krytyczne oceny takich osób jako egoistów, jednostek niedojrzałych, niedorosłych, wygodnych, hedonistycznie nastawionych do życia: „Ludzie są po prostu egoistami, są bardzo wygodni, no tak mi się wydaje, że strasznie zmienia człowieka nieposiadanie dzieci, potem” [K14]; „Dlaczego nie chcą? Dlatego, że jest wygodniej żyć. Dlatego, że nie trzeba się łączyć, można wychodzić, wracać, kiedy się chce. Można mieć tego partnera czy innego partnera. Nie ma, nie trzeba być tym odpowiedzialnym, tym wszystkim, o czym tutaj przed chwilą mówiliśmy. Po prostu wygodnictwo" [M2, FGI_4]. Niektórzy 
badani skłonni byli zaakceptować decyzję o pozostaniu bezdzietnym, gdy osoba ją podejmująca kieruje się dobrem dziecka (którym nie mogłaby się zająć, ze względu na stan zdrowia, niestabilną sytuację finansową), a nie własną wygodą.

Wreszcie, badani zauważali, że zjawisko dobrowolnej bezdzietności jest marginalne, tzn. dotyczy niewielu osób: „marginalnie bym traktował kwestię osób, które z wyboru porzucają ojcostwo, macierzyństwo” [M11]; „Ja myślę, że to są wyjątki. Zdarzają się, ale to są wyjątki” [K2, FGI_3]. Za takim punktem widzenia kryje się silne przekonanie o naturalnej potrzebie posiadania potomstwa, odczuwanej przez zdecydowaną większość ludzi, poza nielicznymi wyjątkami. Niektórzy podkreślali, że nie znają takich osób: ,chyba wśród tych moich koleżanek nie ma takiej, która mówi, że nie chce mieć dzieci, co nie znaczy, że ja nie uważam, że tacy ludzie nie istnieją na świecie i że nie mają prawa żyć" [K1]. A zatem negowano możliwość upowszechnienia się nowego wzoru roli płciowej, niezawierającego w sobie roli rodzicielskiej.

Drugi typ poglądów na temat rodzicielstwa jako społecznego nakazu obowiązującego kobiety i mężczyzn - typ nowoczesny, przejawiał się w odrzuceniu wymogu posiadania dziecka i przyznawaniu jednostkom prawa do decydowania o sobie, w tym o byciu matką/ojcem: „To jest chyba indywidualna sprawa każdego" [M12]; „Ja jakby, żeby czuć się kobietą potrzebowałam tego, żeby być matką, natomiast rozumiem kobiety, które nie chcą być matkami...." [K15]. Stwierdzano, że możliwe są inne formy „spełnienia się" - poza orientacją na rodzinę, możliwa jest orientacja na pracę zawodową [K20]; „dla mnie nie jest to dziwne, chcą się spełniać w innej dziedzinie, może rzeczywiście nie czują się, że będą dobrymi matkami, niech idą tą swoją drogą obraną, niech się spełniają" [K2_FGI_1]. Fakt, że sami badani mieli dzieci, nie powodował braku akceptacji i zrozumienia osób niebędących rodzicami: ,Ja nie jestem faszystką, jeśli chodzi o posiadanie dzieci. Mam takie koleżanki, które nie mają dzieci i uważam, że każdy po prostu żyje tak jak on chce żyć” [K1]; ,[...] kobieta, która nie ma dziecka, po prostu taką drogę wybrała i tak jest po prostu. To nie jest tak, że się od razu muszę zastanawiać, o Boże, a może ona jest chora i dlatego nie może mieć dzieci i dlatego, jaka jest biedna, trzeba jej współczuć. Nie, po prostu taką wybrała sobie drogę życiową i w porządku" [K9]. Podkreślano, że takie osoby nie są w żaden sposób gorsze, dlatego, że nie mają dzieci: „Mamy znajomych, którzy twardo powiedzieli, że nie chcą mieć dziecka i się o to dziecko nie starają. Są normalnymi ludźmi, świetnie się z nimi dogadujemy" [M12]. Zwracano uwagę, że być może brak obciążeń obowiązkami rodzicielskimi pozwoli im na „zrobienie czegoś dobrego”, wykorzystanie swojego potencjału na innej płaszczyźnie.

Badani kwestionowali traktowanie macierzyństwa i ojcostwa jako niezbędnego elementu kobiecości i męskości, nie wiązali tego z rolą płciową: „Nigdy w ten sposób się nad tym nie zastanawiałem, że przez to, że jestem ojcem dziecka, to jestem bardziej męski. Nie rozważałem tego w tych aspektach” [M2]; „Chyba nie jest to warunkiem, warunkiem kobiecości posiadanie dziecka. Myślę, 
że można być kobiecą bez dziecka. To jest kwestia zupełnie innego typu, ja bym to tak oceniła” [K3]; „Nigdy nie rozpatrywałem tego pod kątem męskości..." [M10]. Stwierdzali, że można być „stuprocentową” kobietą, „stuprocentowym mężczyzną", nie mając dziecka i realizując się na przykład na płaszczyźnie zawodowej [M9]; „nie tu bym upatrywał kobiecości, to nie jest jakby element, który miałby decydujące znaczenie do tego, czy można by powiedzieć właśnie, że jest kobieca czy nie, czy jest męski czy nie" [M17]. Inni z kolei zastanawiali się nad sensem takich pojęć jak ,prawdziwa kobieta”, „prawdziwy mężczyzna”, odrzucali jakiekolwiek gotowe definicje i schematy, podkreślali ich względność: „Natomiast to jest też kwestia wyjaśnienia, co się rozumie przez «prawdziwą kobiecość», co jest «prawdziwie męskie». Nie trzeba być ojcem, żeby, nie wiem, być dobrym facetem, człowiekiem, poświęcić się dla jakiejś sprawy. To nie jest współzależne” [M3]; „Nigdy się nie zastanawiałem nad tym, co to znaczy «prawdziwy mężczyzna». Każdy co innego, tak. Jeden jest prawdziwym mężczyzną, bo umie wypić litr wódki, tak. Nie, no nie wiem. [...] Myślę, że bardziej się czułem prawdziwym mężczyzną na przykład jak robiłem dużo jakichś prac w domu, remontowałem, przygotowywałem dom, żeby tutaj zamieszkać. A to, że mam dziecko..." [M5]. Jeden z mężczyzn odrzucał stereotypowy wizerunek mężczyzny, podkreślając, że dla niego bardziej męskie jest bycie opiekuńczym niż bycie „macho”: „Dla mnie, prawdziwie, nie wiem, bardziej męski, jeżeli chodzi tutaj o mężczyzn jest ten, który nawet jeżeli ma posturę jakiegoś niedźwiedzia, wielki jest a idzie sobie z małym dzieckiem czy prowadzi wózek widać, że on się tam opiekuje czymś. Bardziej na tym polega według mnie męskość niż na tym, że stoi sobie jakiś chłystek w skórze i tam pluje, czy pije piwo i to jest dla niego, że on jest twardy, bo zabluźni czy pójdzie na mecz" [M7]. Inny badany zauważył, że samo zostanie ojcem w sensie biologicznym nie jest żadnym osiągnięciem, jeśli nie towarzyszy temu bycie odpowiedzialnym rodzicem: „można gdzieś kiedyś nie być do końca świadomym swoich czynów i w ten sposób zostać ojcem, co często młodzieży się zdarza" [M6]. Mamy tu zatem odróżnienie biologicznego i społecznego wymiaru roli rodzicielskiej. Samo spełnienie wymogu prokreacji (spłodzenie potomstwa) nie jest traktowane jako realizacja roli ojca. Taki wąski sposób rozumienia ojcostwa mieścił się w tradycyjnym modelu płci, który jednak obejmował także takie ojcowskie zadania, jak materialne utrzymanie potomstwa oraz wychowanie.

Zwracano uwagę, że decyzja o dziecku musi być przemyślana, świadoma: „Ja mówię, bardzo ważne jest to, żeby to było odpowiedni moment w życiu kobiety, żeby ona tego chciała, no i żeby miała odpowiedniego partnera, naprawdę. Bo nie ma co się bawić w półśrodki, no bo znam takie sytuacje, kiedy to była nieprzemyślana decyzja, może z nieodpowiednią osobą i naprawdę potem można sobie spaprać całe życie” [K1]; „najgorsi nie są ci, którzy nie chcą mieć dzieci, najgorsi są ci co nie chcą, a mają" [M19]. W wypowiedziach badanych pojawiały się opinie, że nie każdy „nadaje się” na bycie matką/ojcem, a zatem kwestionowano tym 
samym istnienie „instynktu” macierzyńskiego czy ojcowskiego: „Niektórzy się nigdy nie będą nadawali" [M8, FGI_2]; ,jest wiele osób, które są takimi egoistami i są tak skupione na sobie, że nawet chyba lepiej by było, gdyby nie miały dzieci, z tego względu, że to dziecko po prostu może być później, wyrosnąć na jakiegoś w ogóle, no emocjonalnego wyrzutka" [K4, FGI_1].

Trzeci typ poglądów na temat rodzicielstwa jako nakazu społecznego można określić jako ambiwalentny. Odpowiada mu sformułowanie: „Nie trzeba być matką/ojcem, każdy ma wybór, ALE...". Osoby je reprezentujące z jednej strony pozostawiały jednostkom możliwość wyboru, czy chcą być rodzicami, z drugiej jednak strony podkreślały, że bycie matką/ojcem czyni człowieka dojrzalszym, dorosłym, bardziej odpowiedzialnym. Dawały tym samym do zrozumienia, że dobrowolna bezdzietność nie jest przez nich do końca akceptowana i zrozumiała: „Do tego trzeba dorosnąć” [M7, FGI_2]; „Ze wszystkich naszych znajomych, którzy tak twierdzili [że nie chcą mieć dzieci] wszyscy już teraz mają dzieci. To jest ciekawe, to jednak chyba jest dojrzałość, prawda?" [K18]. Wskazywano, że zostanie matką/ojcem sprawia, że jednostka staje się odpowiedzialna, zmusza ją, by „dorosła”. Rodzicielstwo traktowano raczej jako istotny element człowieczeństwa niż kobiecości i męskości, coś co wzbogaca kobietę i mężczyznę jako człowieka: „taki pozytywny aspekt człowieczeństwa to jest to, że człowiek posiada dzieci” [K18]; „Znaczy, ja uważam, że wtedy [gdy nie ma się dzieci] brak jakiegoś pierwiastka z naszego człowieczeństwa” [K4, FGI_4]; „,...] na pewno wzbogaca, otwiera jakieś nowe horyzonty, perspektywy, się okazuje, że człowiek robi rzeczy, których by nigdy wcześniej nie robił, to niewątpliwie. Tak, no zmienia się jakieś podejście do pewnych rzeczy, do wielu rzeczy" [M7, FGI_2]. A zatem osoby rezygnujące z rodzicielstwa pozbawiają się tych doświadczeń: ,ja też rozumiem tych ludzi, którzy dokonują takiego wyboru, ale na pewno coś tracą i tu nie ma dyskusji, może zyskują, być może to, co zyskują jest dla nich bardziej cenne, ale, że coś tracą, to nie ulega żadnej wątpliwości” [M15].

W wypowiedziach badanych pojawiały się uwagi, że mimo wszystko decyzja o nieposiadaniu potomstwa jest „troszkę dziwna” i nie do końca zrozumiała: „Znaczy, ja bym nie chciała oceniać, bo to jest wybór każdej osoby, ale ja to tak zawsze wiedziałam, ja bardzo zawsze lubiłam dzieci i wiedziałam jakby, że kiedyś będę chciała je mieć, tak, że... No może troszkę dziwne to dla mnie jest, no ale... właśnie każda osoba jest inna i szanuję to, że ktoś może nie chcieć mieć dzieci” [K5]. Postawę zawierającą zarówno akceptację dobrowolnej bezdzietności, jak i brak zrozumienia takiej decyzji wyraża następujące sformułowanie: ,jeżeli ktoś wybiera, że nie chce mieć dziecka, to jego problem" [K6, K17], dowodzące, że w przekonaniu respondentek nieposiadanie dziecka może się okazać problematyczne. Jak ujęła to inna uczestniczka badania: „Wydaje mi się, że każdy powinien mieć prawo wyboru, nie chce mieć dzieci, proszę bardzo, nikt nikogo nie zmusi. Natomiast pocieszającym jest to, że w tej chwili, statystyki przynajmniej tak pokazują, że i tak zaczyna rodzić się więcej dzieci”[K5, FGI_1]. 
Podsumowując, typologia stanowisk uczestników badania wobec rodzicielstwa jako konieczności versus wyboru pokazuje ich zróżnicowanie. Obok tradycyjnych przekonań, odwołujących się do „natury” i biologii, podkreślających znane z góry przeznaczenie człowieka, pojawiały się poglądy nowoczesne, otwarte, przyznające jednostkom autonomię, podmiotowość, wolność w decydowaniu o sobie. Przekonania części badanych mieściły się pomiędzy tymi krańcami kontinuum. Ich wypowiedzi odczytać można jako próbę bycia „politycznie poprawnym", wyraz przekonania, że nie powinno się niczego nikomu narzucać, ale... W rezultacie przeprowadzonej analizy można zauważyć, że macierzyństwo i ojcostwo nie jest rozumiane przez znaczną część respondentów jako niezbędny element kobiecości i męskości. Sprowokowani przez badacza do takiego spojrzenia na rodzicielstwo, podkreślali, że nigdy w ten sposób o rodzicielstwie nie myśleli. Częściej natomiast traktowali je jako element człowieczeństwa. Z drugiej strony, opinie odmawiające bezdzietnym kobietom „pełnej” czy „normalnej” kobiecości i brak takich uwag w odniesieniu do mężczyzn, świadczą o istnieniu ,podwójnych standardów" w ocenie obu płci i silniejszego nakazu macierzyństwa niż ojcostwa.

\subsection{Konkluzje}

Nowoczesne przekonania na temat kobiecości i męskości części uczestników badania pokazują, że tradycyjny model płci przestaje obowiązywać, a przynajmniej przestaje być traktowany jako jedyny właściwy. Młodzi wykształceni Polacy kwestionują takie elementy tradycyjnego modelu, jak polaryzacja płci i uzasadniający ją biologiczny esencjalizm. Wynika to z ich niezgody na gotowe schematy, w których mieliby się mieścić jako kobiety i mężczyźni o określonych cechach i rolach do spełnienia. Zamiast reprodukować strukturę - społeczne nakazy dotyczące kobiecości i męskości - dokonują jej zmiany, przyznając sobie tym samym prawo do wolności, podmiotowości i życia w zgodzie z sobą.

Badani, podkreślając, że tradycyjny model płci jest czymś nieaktualnym, czymś, co dotyczyło wcześniejszych pokoleń, ale nie ich samych, wyrażali przekonanie o konieczności zmiany. Dostrzegali, że nie da się podtrzymywać tradycyjnego modelu kobiecości i męskości, bo nie odpowiada on cechom współczesnego społeczeństwa - indywidualizacji, wolności i podmiotowości jednostki, równości kobiet i mężczyzn (przynajmniej na poziomie prawnym oraz wśród deklarowanych wartości). Jak pokazała chociażby analiza stereotypów płci w wymiarze opisowym i normatywnym, w charakterystykach, jacy powinni być mężczyźni i kobiety, pojawiały się cechy nieodpowiadające tradycyjnemu modelowi płci, na przykład opiekuńczość i czułość mężczyzny, siła, zdecydowanie, kreatywność i wszechstronność kobiety. O zachodzącej, dostrzeganej zmianie kulturowej definicji męskości opowiadał jeden z respondentów, zaznaczając, że bycie „macho" już nie wchodzi w rachubę: „Teraz trzeba być metroseksualnym i nie można nie 
współczuć żonie, albo nie pomagać, albo nie pocieszać, nie być przy porodzie" [M19]. Inny zauważał niejednoznaczność współczesnego pożądanego wizerunku mężczyzny: „mężczyźni nie muszą już być macho, mężczyźni zaczynają być metroseksualni, to jest tak naprawdę poszukiwanie bycia mężczyzną, co to znaczy, zdefiniowanie się, co to znaczy być mężczyzną" [M6].

Krytyczna postawa wobec stereotypów płci, świadomość ich ograniczającego i upraszczającego charakteru, dostrzeganie zmiany społecznych oczekiwań wobec kobiet i mężczyzn czy przekonanie o wolności jednostki w realizacji ról płciowych jest wyrazem podmiotowości i refleksyjności młodych wykształconych Polaków. Sprzeciwiają się oni gotowym kulturowym schematom, przyznając prawo sobie i innym do wyboru własnego sposobu na życie, w tym bycia kobietą/mężczyzną, matką/ojcem.

Z drugiej jednak strony, konserwatywny sposób myślenia o płci przejawiający się w wypowiedziach części badanych dowodzi siły i trwałości tradycyjnego modelu. O głębokiej internalizacji stereotypów kobiecości i męskości świadczy automatyczne odwoływanie się do nich przez badanych w pytaniu o definicje kobiecości i męskości. Odwieczne traktowanie obu płci jako przeciwieństw powoduje, że dla niektórych jednostek dychotomia płci jest czymś oczywistym, nawet jeśli oni sami i ich partnerzy z ich cechami, zachowaniami, rolami się w niej nie mieszczą. Oceniają zjawisko dobrowolnej bezdzietności jako nienaturalne, czy nienormalne, dając tym samym wyraz przekonaniu o normatywnym charakterze ról płciowych, których koniecznym, według nich, elementem są biologiczne role rodzicielskie. Osoby te traktują strukturę, w której przyszło im funkcjonować, jako coś danego i gotowego, niepoddającego się zmianie, czy też w ich przekonaniu niewymagającego zmiany. Znajduje to wyraz w stwierdzeniach, że „zawsze tak było", „tak jest urządzony świat”, a skoro tak, to jest to uzasadnione, dobre, funkcjonalne itp. Stąd też w swoich przekonaniach i odpowiadających im zachowaniach - praktykach społecznych - jednostki te odtwarzają i utrwalają tradycyjny model płci. 


\section{Rozdział 7. Wzory roli matki i roli ojca realizowane przez młodych wykształconych Polaków}

\subsection{Sposób definiowania macierzyństwa i ojcostwa przez badanych}

Zgodnie z przyjętą koncepcją roli społecznej, sposób jej realizacji (aspekt behawioralny) powiązany jest $\mathrm{z}$ własną definicją roli jednostki, tworzoną na podstawie selekcji i interpretacji strukturalnie narzuconych nakazów. Analiza wzorów macierzyństwa i ojcostwa młodych wykształconych Polaków wymaga poznania przekonań badanych na temat ról rodzicielskich. W badaniu pytano zatem respondentów, co oznacza według nich bycie matką i bycie ojcem, jak definiują te role. W zogniskowanych wywiadach grupowych wykorzystano, podobnie jak w badaniu przekonań na temat kobiecości i męskości, test niedokończonych zdań. Uczestnicy indywidualnie dopisywali zakończenia zdań: „Bycie matką oznacza...”, „Bycie ojcem oznacza...”, następnie określenia te były zestawiane i dyskutowane w grupie. Chodziło o uchwycenie pierwszych skojarzeń z rolami rodzicielskimi. Wyniki pokazuje tabela $5^{1}$.

$\mathrm{Na}$ podstawie zebranego materiału (w wywiadach swobodnych oraz zogniskowanych wywiadach grupowych) wyodrębniono dwa typy przekonań na temat macierzyństwa i ojcostwa. Pierwszy typ odpowiada nowoczesnemu modelowi płci. Reprezentujące go osoby traktowały role matki i ojca jako podobne, opierające się na tych samych cechach, zadaniach, relacji z dzieckiem. Wolały mówić o rodzicielstwie zamiast rozdzielać macierzyństwo i ojcostwo, podkreślały ich podobieństwo i wspólne realizowanie: „Myślę, że tak naprawdę rola mamy i ojca są podobne, czyli mówiąc generalnie bycie rodzicem, to dla mnie, przede wszystkim być jakby «autorem» tego dziecka w pewnym sensie, a z drugiej strony danie mu takiego poczucia bezpieczeństwa, przekazanie wiedzy, to co może przekazać rodzic, tak żeby to dziecko dało sobie radę potem samodzielnie. I to jest dla mnie takie zadanie, być rodzicem” [K20]; „Rola rodziców ta sama, no wychować dziecko, pokazać mu świat, pokazać mu to, jak zrobić różne rzeczy, jak sobie radzić w życiu, to jest najważniejsze dla dziecka” [M13].

${ }^{1}$ Nie zawsze są to określenia $\mathrm{w}$ dosłownie takiej formie, jak podawali je badani; na użytek opracowania podobne sformułowania zostały zgrupowane i nazwane powtarzającym się w nim określeniem. 
Tabela 5. Rodzaje określeń kończących zdania „Bycie matką oznacza...”, „Bycie ojcem oznacza...”, z uwzględnieniem płci uczestników

\begin{tabular}{|c|c|c|}
\hline Określenie & Kobiety & Mężczyźni \\
\hline $\begin{array}{l}\text { Bycie matką } \\
\text { oznacza }\end{array}$ & $\begin{array}{l}\text { odpowiedzialność (5) } \\
\text { poświęcenie (4) } \\
\text { radość, szczęście (3) } \\
\text { spełnienie (2) } \\
\text { miłość (2) } \\
\text { zmianę w życiu na lepsze, życie } \\
\quad \text { nabrało sensu (3) } \\
\text { dar } \\
\text { bycie troskliwym, opiekuńczym } \\
\text { czułość } \\
\text { przejęcie wszystkich obowiązków } \\
\quad \text { domowych }\end{array}$ & $\begin{array}{l}\text { odpowiedzialność (4) } \\
\text { spełnienie (4) } \\
\text { poświęcenie (2) } \\
\text { dbanie o dzieci (2) } \\
\text { całkowitą zmiana dotychczasowego } \\
\quad \text { życia } \\
\text { być osobą zapobiegawczą } \\
\text { miłość } \\
\text { posiadanie czasu dla dziecka }\end{array}$ \\
\hline $\begin{array}{l}\text { Bycie ojcem } \\
\text { oznacza }\end{array}$ & $\begin{array}{l}\text { odpowiedzialność (10) } \\
\text { utrzymanie rodziny (2) } \\
\text { troskliwość (2) } \\
\text { świetną zabawę } \\
\text { zejście na drugi plan } \\
\text { dać bezpieczeństwo } \\
\text { odkrycie „nowej wrażliwości” } \\
\text { spełnienie } \\
\text { szczęście } \\
\text { dojrzałość }\end{array}$ & $\begin{array}{l}\text { odpowiedzialność (5) } \\
\text { wychowanie (3) } \\
\text { poświęcenie } \\
\text { naukę cierpliwości } \\
\text { dorastanie } \\
\text { zwiększenie obowiązków } \\
\text { rozpieszczać dziecko, dbać o nie } \\
\text { zmianę stylu dotychczasowego życia } \\
\quad \text { oraz nowe wyzwania } \\
\text { większe zaangażowanie w sprawy } \\
\quad \text { rodziny } \\
\text { radość } \\
\text { posiadanie czasu dla dziecka }\end{array}$ \\
\hline
\end{tabular}

Źródło: Opracowanie własne.

Jako cechę rodzicielstwa, zarówno macierzyństwa jak i ojcostwa, wymieniano przede wszystkim odpowiedzialność. Wskazywano, że od rodziców obojga płci zależy życie dziecka tu i teraz oraz w przyszłości, to oni bowiem mają wpływ na jego prawidłowy rozwój - fizyczny, psychiczny, emocjonalny i umiejętność funkcjonowania w społeczeństwie: „Jest to bycie no takim opiekunem odpowiedzialnym za życie tego małego człowieka, za to co się dzieje z nim teraz i za to co się stanie z nim później, co z tego małego człowieka wyrośnie, jak jego życie będzie przebiegać na kolejnych etapach, w ogóle całe jego życie” [M10]; „ode mnie będzie zależało, kim będzie moje dziecko" [K18]. Mówiono o ciężarze tej odpowiedzialności, o pracy, jaką muszą włożyć rodzice w odpowiednie ukształtowanie dziecka i przygotowanie je do życia, w „produkcję jego osobowości” (Urbańska 2012). Wychowawcza rola rodzica pojawiała się zarówno w definicjach macie- 
rzyństwa jak i ojcostwa. Właściwe wychowanie dziecka postrzegano jako trudne i stresujące zadanie, wymagające od rodziców nieustannego kontrolowania swojego postępowania wobec dziecka, wiążące się z niepewnością, czy nie popełniają błędów: „Każda nasza decyzja teraz wpływa na jego życie w przyszłości. [...] Tylko że nigdy nie wiadomo, czy robimy źle, czy dobrze" [K2]. Wspólnym elementem pojawiającym się w definicjach roli matki i ojca, obok odpowiedzialności i wychowania, było również zapewnienie bezpieczeństwa dziecku, jego ochrona: „No i cały czas się myśli o tym, żeby zapewnić bezpieczeństwo, to jest osoba bezbronna, zależna w 100\% od ciebie" [M7]. I kobiety, i mężczyźni mówili także o satysfakcji i dumie związanej z obserwowaniem dorastania dziecka, nabywania przez nie nowych umiejętności oraz poczuciem własnego udziału w tym procesie: „A to ma w sobie niesamowicie dużo uroku, jak się obserwuje dziecko, kiedy ono zaczyna robić rzeczy genialne, w opinii rodziców wszystko jest genialne, to że dziecko kojarzy, coś pokazał, coś tam powiedział” [K11]; „To jest radość z tego, że można poopowiadać choćby znajomym czy kolegom w pracy, co nowego mądrego wymyśliło dziecko, to jest jakaś duma z faktu, że rośnie, że poznaje świat, że robi się coraz bardziej sprawna, z tego że człowiek czegoś ją potrafi nauczyć" [M13] „A szczerze powiedziawszy, tak już zupełnie poczułem satysfakcję z bycia ojcem po dwóch latach, kiedy on zaczął mówić, kiedy widziałem już ewidentnie efekty tego, że, naszego wspólnego wpływu" [M8].

Przejawem nowoczesności w podejściu do rodzicielstwa było także charakteryzowanie ojcostwa za pomocą określeń kojarzonych częściej z rolą matki, takich jak troskliwość, dbanie o dziecko, poświęcenie czy spełnienie (tabela 5). Jedna z respondentek „bycie ojcem” określiła jako odkrycie „,nowej wrażliwości” przez mężczyznę. Taki sposób postrzegania roli ojca wskazuje na odrzucenie ojcostwa i męskości w tradycyjnym ujęciu i upodobnienie się do siebie (androgynizację) ról rodzicielskich.

Badani o nowoczesnych poglądach na temat rodzicielstwa kwestionowali istnienie specyfiki kobiecości i męskości, a tym samym roli matki i ojca. Różnice w zachowaniach kobiet i mężczyzn w rolach rodziców interpretowali jako związane z różnicami osobowości, wychowania, innymi doświadczeniami wyniesionymi z domu, a nie z płcią biologiczną. Poniżej fragment rozmowy z jedną z par, dotyczący różnych relacji ojców z dzieckiem.

M: To jest kwestia osobowości każdego mężczyzny.

K: Kwestia wrażliwości.

M: Być może to jest też kwestia wychowania. Bo nie każdy ma dobry kontakt, wynosi z domu ciepło rodzinne. A potem starają się przekazywać to samo, swoje doświadczenia przelewają na własne dziecko. Ale trudno tutaj tak szufladkować, że generalnie faceci to tak, a kobiety tak, nie. To są chyba sprawy indywidualne. [W3] 
Respondenci odrzucali podział ról płciowych i kulturowe schematy określonych zadań i zachowań narzucane jednostkom jako matkom i ojcom. Wskazywali na „uniwersalność” człowieka, jego elastyczność i umiejętność dostosowania się do sytuacji: „Każdy z nas jest uniwersalny i zastępuje jedno i drugie, we wszystkich rzeczach, nie?” [M2]; „Moglibyśmy się nawzajem zastąpić, czy wymienić zadaniami...” [K12]; kobieta też „potrafi wziąć siekierę” [K7], a mężczyzna ugotować, pozmywać, przewinąć dziecko. Podkreślali przy tym, że umiejętność zajmowania się dzieckiem nie jest przypisana wyłącznie kobiecie i mężczyzna poradziłby sobie z opieką nad dzieckiem równie dobrze jak matka, gdyby to on został z nim w domu. Ewentualna „przewaga” kobiet, ich większa sprawność w czynnościach pielęgnacyjnych wynika, zdaniem badanych, jedynie z większej ilości czasu spędzanego z dzieckiem. Nie ma według nich takich cech, które predestynowałyby matkę do bycia lepszym opiekunem: „Bo takie rzeczy typu, że trzeba pamiętać o tym, że zawsze trzeba mieć butelkę, jeszcze dodatkowy soczek, bo dziecku się może zachcieć pić, czy dodatkową pieluszkę, czy coś, to tego się można nauczyć, kilka razy bym mu powiedziała. [...] gdyby on musiał się zajmować dzieckiem, to on by się spokojnie tego wszystkiego nauczył" [K9]. W ten sam sposób wyjaśniano lepszy kontakt matki z dzieckiem, zauważając, że jest to znów konsekwencja spędzania z nim więcej czasu w pierwszym okresie życia, a nie bycia kobietą: „Mnie się wydaje, że kobiecie chyba pomimo wszystko jest łatwiej nawiązać ten kontakt z dzieckiem, bo spędza z nim więcej czasu, bardziej to dziecko zna. [...] ale to chyba jest naturalne i przypuszczam, że gdyby ojciec siedział, to matce też byłoby trudniej nawiązać relację z dzieckiem, bo, bo nie znałaby tego dziecka aż tak bardzo" [K3]. Badani wskazywali zatem na taki sam potencjał kobiety i mężczyzny, jeżeli chodzi o umiejętność opieki nad dzieckiem, chociaż niektórzy przyznawali, że ,aktywizowanie” tego potencjału może zająć mężczyźnie trochę więcej czasu: „Może to rzeczywiście z tego względu, że kobieta wcześniej jak gdyby obserwuje to dziecko, jest cały czas z nim i łatwiej ma, łatwiej jej to przychodzi. Na pewno może facet, pod warunkiem, że się postara i wcale nie przychodzi mu to znacznie trudniej niż kobiecie" [M2]. Jak zauważyła jedna $\mathrm{z}$ respondentek, skoro są i mężczyźni zaangażowani i chętnie opiekujący się dziećmi, szybko nawiązujący z nimi kontakt i mężczyźni, którym trudno jest zbudować więź z dzieckiem, to jest to kwestia nie płci, a osobowości [K19].

Przekonanie o równych kompetencjach rodziców bez względu na płeć znalazło wyraz w przypisywaniu ojcom przez jednego z respondentów rodzicielskiego instynktu, pojawiającego się w momencie narodzin dziecka, rozumianego jako poczucie odpowiedzialności za dziecko, chęć zapewnienia mu jak najlepszej opieki, niewyobrażanie sobie życia bez dziecka: ,[...] w momencie, kiedy dają dziecko na ręce, przecina pępowinę, biorę własną córkę, widzę, jak ona patrzy, szok, emocje. Zaczyna się coś takiego wytwarzać, no ja mogę to powiedzieć z punktu widzenia ojca właśnie, że zaczyna się rodzić jakiś instynkt. Może on nie jest od razu ukształtowany w pełnej swojej wartości, natomiast czuć, że czuje się człowiek od 
razu odpowiedzialny za to, że trzyma własne dziecko na rękach, stara się od razu zapewnić mu łokciami, że tak powiem, miejsce na świecie. No jest to takie uczucie, w sumie trudno to określić, trudno to ubrać w słowa. Chociaż z czasem stara się człowiek o coś takiego, że nie wyobraża już sobie życia bez dziecka" [M3].

Powyższa wypowiedź pokazuje jeszcze inne „nowe” oblicze kobiecości i męskości realizowanych przez uczestników badania: przyznanie jednostkom bez względu na płeć równego prawa do przeżywania w podobny sposób oczekiwania dziecka, jego narodzin, bycia rodzicem. Respondenci podkreślali podobne, równie intensywne odczucia kobiety i mężczyzny towarzyszące na przykład badaniom USG, kiedy pierwszy raz zobaczyli swoje dziecko, czy pierwszym wspólnym chwilom w powiększonym gronie: „Tak, Michał był faktycznie ze mną na każdym badaniu USG. Na pierwszym na przykład był taki bardzo wzruszający moment, kiedy usłyszeliśmy pierwszy raz bicie serca i to było takie, oczywiście łzy w oczach itd., natomiast takie niesamowite było to, że, znaczy dla nas takie zaskoczenie, że tak głośno było strasznie słychać, no to takie duże emocje. Nie wiem, chyba podobnie zapamiętaliśmy?" [K6]. Mężczyźni opowiadali o próbach komunikowania się z dzieckiem w brzuchu matki, by nie czuć się pozbawionym fizycznego kontaktu z dzieckiem, jaki ma kobieta: „starałem się jakoś rozmawiać z dzieckiem, jak było jeszcze w brzuchu, głaskać, dotykać, wyczuwać wszystkie ruchy" [M7]; „Ja się nie czułem pozbawiony fizycznych odczuć, bo ja od najwcześniejszych momentów, odkąd oczywiście można było, tropiłem wszelkie ruchy, wszelkie dźwięki, bicie serduszka. Tak, że ja się nie czułem jakoś odizolowany od tego" [M15]; „mój mąż był fantastyczny, bo właściwie przez kilka miesięcy mojej ciąży codziennie o godzinie 22:30 miał spotkanie ze swoim synem nienarodzonym jeszcze i to było bardzo piękne naprawdę, myśmy mu faktycznie puszczali muzykę, mówiliśmy do niego, kiedy był w brzuchu i to było bardzo fajne, że ja miałam masowany brzuch też codziennie o tej samej porze i nasze dziecko w pewnym momencie już było tak przyzwyczajone do tego, że jest miziane" [K6]. Dwóch mężczyzn przyznało, że odczuwali zazdrość o możliwość karmienia piersią przez matkę. W jednej z par kobieta ściągała co jakiś czas pokarm, żeby ojciec mógł też nakarmić dziecko: „nie wiem, czy pamiętasz, ja ci obiecałam, że będę ci raz w tygodniu ściągać pokarm i będziesz karmił butelką i masz sporo zdjęć jak karmiłeś. [...] czasem rzeczywiście tak robiliśmy, że ja ściągałam mleko i już" [K6].

Z drugiej strony, niektórzy badani wyrażali niechęć wobec jakichkolwiek schematów reagowania w taki a nie inny sposób w pewnych sytuacjach (na przykład porodu) czy okazywania określonych emocji w relacji z dzieckiem, przyznając matkom i ojcom prawa do przeżywania rodzicielstwa na swój własny sposób. Takie podejście jest wskaźnikiem nowoczesnego modelu płci i ról rodzicielskich. Jedna z par podkreśliła w wywiadzie, że nie można odmawiać mężczyznom silnej więzi z dzieckiem tylko dlatego że okazują oni miłość w inny sposób niż kobiety. Jak stwierdziła respondentka, ,[...] ja nie wymagałam od niego (męża), żeby on 
stał nad wózeczkiem czy tam łóżeczkiem i robił «kuci kuci kuci», chciał to sobie «pokuciał» dwie minuty i poszedł, no. Wiadomo, że dla mnie, że ja się roztkliwiam nad tym dzieckiem, natomiast dla niego inne rzeczy były ważniejsze. On na przykład siedział i pięć godzin czy pięć dni, nie wiem ile, wybierał wózek, bo to dla niego było coś ważnego, istotnego itd.” [K19]. Jej partner dodał: „Ale wbrew pozorom to jest też więź z dzieckiem" [M19].

Odrzucenie przekonania o uniwersalnym doświadczeniu nie tylko rodzicielstwa, ale także macierzyństwa znajdowało wyraz w wypowiedziach kobiet dotyczących ich stanu emocjonalnego w pierwszych dniach po narodzinach dziecka. Respondentki kwestionowały wyidealizowane obrazki macierzyństwa popularyzowane w przekazach medialnych. Przyznawały, że narodzinom dziecka nie towarzyszy pojawienie się natychmiastowej miłości do dziecka. Jak opowiadała jedna z kobiet: „Jak mi go przynieśli to jeszcze nie było to. Te emocje nie pojawiają się chyba od razu. [...] Nie pojawiły się tak, że «kocham go najbardziej na świecie», nie było tego od razu. Tylko dopiero tak jakoś z czasem. Najpierw tylko obowiązek, że trzeba się nim opiekować, ale ta miłość przyszła dopiero może po trzech, czterech miesiącach. Tak przynajmniej było w moim przypadku" [K2]; „Dziwne, powiem szczerze, że dziwne. Zupełnie jakoś tak, wiedziałam, że to jest mój syn... [...] I powiem szczerze, że ta miłość do niego narastała, to nie było tak, że go zobaczyłam i od razu wielka miłość. To trzeba przyznać, że to nie jest tak. [...] trzeba się było dostosować do tej sytuacji, przyzwyczaić” [K10]; „Ale to początkowo nie dochodzi, że to jest twoje dziecko, to jeszcze dużo czasu musiało upłynąć, zanim się wie, że jest to dziecko. Tak to, to urodziło się i trzeba coś z nim robić, ale to jeszcze po prostu nie, przynajmniej u mnie, taka psychika, nie wiem, czy przerażenie, czy..." [K14]. Wypowiedzi uczestniczących w badaniu kobiet pokazują „nowe oblicze” macierzyństwa, świadczą o jego „odczarowaniu”, „demitologizacji”. Respondentki otwarcie mówiły o negatywnych emocjach i odczuciach jakie towarzyszą macierzyństwu, o przeżywaniu baby bluesa i depresji poporodowej, o byciu ,matką niedoskonałą”: „Ja to w ogóle miałam na pewno jakąś depresję poporodową. Ale to chyba każda kobieta ma. Wtedy nie wiedziałam, że to jest depresja poporodowa. Ale realnie przez pierwsze dni ja się czułam w ogóle tak, że jakby nie czułam tej miłości takiej, co wszyscy trąbią, że taka wszechogarniająca miłość do dziecka, która cię wypełnia. Ja po prostu byłam zmęczona i zestresowana, że jak mała się budziła w nocy i płakała, to ja byłam wściekła na nią, wręcz tak" [K15]. Ponadto, niektóre matki uczestniczące w badaniu podważały przekonanie o „,naturalnych” umiejętnościach i wiedzy, predestynujących je do opieki nad dzieckiem. Zdaniem jednej z kobiet, naturalny jest raczej lęk i obawa towarzyszące pierwszym kontaktom z dzieckiem i czynnościom pielęgnacyjnym, jakie trzeba wykonać: ,[...] na przykład ja też bałam się go trzymać przy kąpieli. [...] to też nie jest wcale tak, że matka z samego faktu, że jest matką od razu nabiera jakąś taką umiejętność w ogóle dokonywania tych wszystkich zabiegów. [...] Nie, natomiast z mojego punktu widzenia to nie jest tak, że, tak jak 
już mówiłam, że kobieta jest z samego faktu bycia kobietą lepiej przygotowana" [K11]. Jedna z kobiet opowiadała o trudnościach z karmieniem piersią, która to czynność, wydawałoby się, powinna być naturalna dla kobiety: „To jednak niby instynkt macierzyński i wszystko, ale to tak do końca nie jest i zanim dziecko się nauczy i zanim ja się nauczyłam, to też te dwa czy trzy dni nam to zajęło" [K13]. Część respondentek zaprzeczała istnieniu macierzyńskiego instynktu, zauważając, że nie każda kobieta za wszelką cenę i przede wszystkim chce zostać matką i nie każda uważa je za swoją życiową misję: „To znaczy, nie potrafię powiedzieć, czy obudził się we mnie instynkt macierzyński, po prostu ja do końca nie potrafię zdefiniować, czym on jest. Ja nigdy nie miałam jakichś takich odczuć, że muszę mieć dziecko i w związku z czym nie potrafiłabym powiedzieć, z jakiego powodu to dziecko musiałabym mieć, tak. Nie wiem po prostu, na czym to polega" [K11].

Drugi typ przekonań na temat macierzyństwa i ojcostwa, częściej reprezentowany w badanej zbiorowości, odpowiada tradycyjnemu modelowi płci. Wiąże się z traktowaniem ról matki i ojca jako różnych, opierających się na innych zadaniach, relacji z dzieckiem. Zdaniem badanych specyfika macierzyństwa i ojcostwa wynika z różnic między kobietami i mężczyznami i podziału ról ze względu na płeć. Obrazuje to następujące stwierdzenie: „Tak to natura wymyśliła, że tak to by była sama matka, ojciec byłby niepotrzebny. Tak to chyba naturalnie jest, że te role są zupełnie inne" [M11]. Charakterystyczne jest tu odwoływanie się do „dyskursu esencjalizującego”, ,naturalizującego” (Šmidová 2008: 290). W wypowiedziach respondentów znaleźć można odwołania do natury, biologii, instynktu. Według jednej z uczestniczek badania, kobiety ,instynktownie” prowadzą dom, myślą o zakupach, o jedzeniu, o sprzątaniu [K9]. Ta sama respondentka opowiadała o swoim zaskoczeniu, że tak łatwo przyszła jej opieka nad dzieckiem, co także wyjaśniała „naturą kobiety”: ,[...] ja sama aż jestem zdziwiona, że to jest takie w naturze kobiety. Ja w ogóle będąc w ciąży się bałam tego, że ja właśnie nie mam takiego instynktu macierzyńskiego. [...] mnie dzieci nie interesowały. A tu się okazało, że jakoś wszystko naturalnie" [K9]. Według innej badanej matka „,instynktownie” rozpoznaje płacz swojego dziecka [K6]. Kolejna respondentka „hormonami” i instynktem thumaczyła fakt, że kobieta jest niejako przygotowana na przyjście dziecka, zdolna do wysiłku i wykonywania mimo zmęczenia wszystkich czynności związanych z opieką nad noworodkiem, czego „naturalnie” nie ma mężczyzna [K1].

W przedstawianych przez badanych definicjach macierzyństwa i ojcostwa pojawiały się następujące różnice między rolami rodziców obu płci. Chociaż odpowiedzialność wskazano jako cechę rodzicielstwa jako takiego, okazało się, że w odniesieniu do roli ojca jest ona przez niektórych respondentów obu płci rozumiana jako konieczność zapewnienia dziecku bytu: „Mężczyzna ma gdzieś tam zakodowane, że on ma utrzymać tę rodzinę i on ma mieć tą odpowiedzialność, tą materialną" [K1, FGI_1]. Jeden z mężczyzn, który utożsamiał ojcostwo z rolą żywiciela rodziny, zastanawiał się, na czym polega rola ojca, gdy to matka utrzymuje 
rodzinę: „Rola ojca według mnie polega przede wszystkim na tym, żeby rodzinie zapewnić byt. To nie ulega wątpliwości. Oczywiście żyjemy w czasach, gdzie i ojciec i matka pracuje, jest wiele przypadków takich, gdzie nawet można powiedzieć, że to matka zapewnia byt i wtedy nie wiem, jaka jest rola ojca" [M9]. Inni jednak odrzucali ograniczanie roli ojca do utrzymywania rodziny, podkreślając również jej aspekt opiekuńczy i wychowawczy: „Pojawia się mała istota, cząstka nas i tak naprawdę wszystko zależy od nas, czego ją nauczymy, jak ją wykreujemy, czy będzie dobrym człowiekiem, tak. To co się zdarzy w tym okresie, kiedy my wychowujemy dziecko, zaprocentuje, zaowocuje albo i nie, w przyszłości. Ja myślę, że tak trzeba postrzegać odpowiedzialność, a nie tylko jako zaplecze finansowe" [M2, FGI_4].

Wśród kobiecych określeń dotyczących męskiej odpowiedzialności (zebranych w wywiadach grupowych za pomocą testu niedokończonych zdań) pojawiały się sformułowania „nauczyć się odpowiedzialności”, „zacząć być odpowiedzialnym”, „większa odpowiedzialność”, czy „przejęcie odpowiedzialności za rodzinę", co uczestniczki badania komentowały w następujący sposób:

K1: Tylko odpowiedzialność, odpowiedzialność. Mężczyzna tylko odpowiedzialność i gdzieś tam...

K3: To znaczy, że jednak są na ogół nieodpowiedzialni.

K1: W wypadku matki to jeszcze to są uczucia, ale mężczyzna... Ja napisałam „szczęście i odpowiedzialność”, później już się pojawiła jakaś „radość”. Ale właściwie wszyscy pozostali tylko „odpowiedzialność” i „odpowiedzialność”. Czyli mężczyzna ma dziecko - odpowiedzialny ma być. Nic więcej. (śmiech)

K4: Ale to wynika właśnie z tego, jak są mężczyźni wychowywani przez matki, jakie tutaj są kody przekazane, jakim są wiecznym dzieckiem [...] i później nagle spada na niego ten grom z jasnego nieba i może stąd wynika to hasło „odpowiedzialność”, bo może do tej pory wcale być nie musiał.

K1: Dopiero jak jest dziecko, to jest odpowiedzialność.

K4: Z tego co obserwuję, tak. [FGI_4]

To przejmowanie odpowiedzialności za drugą osobę, gdy zostaje się ojcem, niektórzy określali jako osiągnięcie dojrzałości przez mężczyznę: „To jest taki chyba najwyższy, zaawansowany stan dorosłości, jaki można osiągnąć, gdzie z chłopca staje się mężczyzną, gdzie człowiek potrafi oddać część swojego życia temu małemu człowiekowi no i czerpać z tego satysfakcję, gdzie przerzuca się satysfakcję z własnego życia na satysfakcję z życia swojego dziecka. To jest tak naprawdę definicja ojcostwa, właściwie dobrego, może dobrego ojcostwa" [M11]. 
Mężczyźni częściej niż kobiety widzieli się w roli wychowawców, uczących dziecko właściwych zachowań, kształtujących ich osobowość, przygotowujących je do życia: „Do tego się w jakiś sposób sprowadza ojcostwo, że przez pewien przynajmniej okres czasu człowiek się czuje w stu procentach odpowiedzialny za kształtowanie osobowości tego dziecka” [M1]; „Ojciec to jest po prostu wyposażenie dziecka w umiejętności, które będą mu potrzebne, żeby odnieść sukces w przyszłości” [M6] „Najważniejsza rola ojca dla dziecka jest taka, żeby wytyczać odpowiednie granice, żeby pozwalać na wszystko, na co można pozwalać, a nie pozwalać na to, na co pozwalać nie należy” [M15]; „Ojciec ma sprawić, żeby dziecko było zaradne w życiu" [M4, FGI_2]. Wychowawczą rolę ojca badani obu płci uzasadniali takimi męskimi cechami, jak: tembr głosu, stanowczość, zdecydowanie, a także umiejętność formułowania krótkich i czytelnych dla dziecka komunikatów [FGI_3]. Wskazywano, że mężczyźni więcej wymagają od dziecka, na mniej im pozwalają, potrafią być bardziej surowi niż matki i zdyscyplinować dziecko.

Uczestniczkom badania macierzyństwo, częściej niż mężczyznom ojcostwo, kojarzyło się z miłością i czułością: „Wydaje mi się, to trochę takie banalne, ale kochać to dziecko jak najbardziej się da i chyba to wszystko, to jest chyba najważniejsze" [K8]. Matki zwracały uwagę na zaspokajanie potrzeb emocjonalnych i psychicznych dziecka jako rolę rodzica: „Nie tylko ten aspekt wychowawczy, też taki aspekt emocjonalny, zapewnić dziecku taki komfort psychiczny i emocjonalny, żeby wiedziało, że ma jakieś oparcie w rodzicach, w matce, w ojcu i żebyśmy byli dla niego takim buforem bezpieczeństwa zawsze” [K18]; „Stwarzać mu takie poczucie bezpieczeństwa, ale niekoniecznie w takim wymiarze fizycznym, prawda, że tutaj się dziecko na przykład nie uderzy w kant stołu [...], ale właśnie jakoś wydaje mi się, ważniejsze to bezpieczeństwo od strony psychicznej, że on jest, nie wiem, bardzo spokojny przy nas" [K7]. Także mężczyźni utożsamiali macierzyństwo z ciepłem, opiekuńczością, troskliwością i miłością. Zaznaczali, że ojcowie także kochają dzieci, ale nie to jest najważniejsze w ich roli: „Od matki oczekujemy, że będzie zawsze przy dziecku, zawsze podporą i zawsze będzie kochać, a od ojca już nikt tego aż tak bardzo nie oczekuje, czy oczekuje w innej formie, nie tak bezpośrednio" [M8, FGI_2]. Uczestnicy badania (zarówno kobiety, jak i mężczyźni) odwoływali się do polaryzacji płci i podziału ról na „,czułą mamę", odpowiadającą za emocjonalny rozwój dziecka, i „,surowego ojca”, uczącego dziecko właściwych zachowań: „Mężczyzna musi być bardziej stanowczy, kobieta raczej bardziej mi się wydaje ciepłą osobą” [M4, FGI_3]; „,[Mężczyźni] właśnie mają być takim jakby wzorcem postępowania przede wszystkim jakby, na pierwszym miejscu, no bo też faceci się nie kleją, nie przyklejają. Wiadomo, że mężczyźni uczą swoje dzieci też miłości i tego wszystkiego, ale w inny sposób, taki męski bardziej. Natomiast mówią no kobiety bardziej chyba pokazują tą taką delikatną stronę, właśnie te emocje i to wszystko. Tak, że to się wszystko równoważy” [K1]; „Bycie matką to jest więcej miłości, natomiast bycie ojcem przekłada się bardziej na wychowanie, naukę [M5, FGI_2]. 
Zdaniem badanych czułość i troskliwość matki jest szczególnie widoczna, gdy dziecku dzieje się krzywda. To matka jest tą osobą, która przytuli i pocieszy: „Mama jest po to, że, nie wiem, jak stłucze się kolano, to żeby przyjść się przytulić [...] ojcowie bardziej tak strofują, są tacy bardziej surowi. Natomiast do mamy można przyjść, wypłakać się, wiadomo, że mama zawsze przytuli. Tak, że wydaje mi się, że tu bardziej taką jakby szalę przechylają te emocje, że tu jest więcej emocji w tym wszystkim” [K1]; „No i zawsze jest tak, że jak coś się dzieje dzieciom, to mama jest ważniejsza, bo taka jest rola mamy, na pewno" [K4]. Warte podkreślenia jest to, że jedna z kobiet biorących udział w badaniu zwróciła uwagę na negatywne skutki stereotypu, według którego matki są bardziej czułe od ojców i to one „są od przytulania” dziecka. Jej jako matce pozwalano w szpitalu nosić i przytulać dziecko wcześniaka do nagiego ciała, co określa się mianem „kangurowania”, podczas gdy nie mógł tego robić ojciec. Uzasadniano to tym, że mężczyzna ma owłosioną klatkę piersiową, poza tym „bo to bliższy kontakt z matką, bicie serca, bo dziecko było w łonie matki". Jak wspomina respondentka: „Walczyliśmy strasznie długo, bo pozwalano tylko matce kangurować, no a na przykład mój mąż bardzo chciał kangurować. I dla nas to był szok w ogóle, no jak mogą nie pozwolić" [K4, FGI_3].

Wskazywano także na inny podział rodzicielskich zadań: gdy ojciec odpowiada za wychowanie potomstwa, matka - za pielęgnację dziecka: „Wydaje mi się, że taka jest przyrodzona rola matki, że jednak matka za tym dzieckiem ciągle gdzieś tam chodzi i wyciera mu tam nos, czy buzię. Na pewno przypisana matce jest rola pielęgnacyjna, kobieta, może z racji, nie wiem, jakiejś takiej delikatności, może jakichś takich wrodzonych umiejętności, no te role pielęgnacyjne robi na pewno lepiej. [...] Natomiast rola ojca, no myślę, że w dużej mierze na pewno edukacyjna, to jest jakby podstawowa" [M11]. Wyrażano przekonanie, że taki podział ról jest naturalny, ,przypisany” czy „przyrodzony” (jak w powyższej wypowiedzi) i wynika z różnic psychologicznych między kobietami i mężczyznami: ,jakby trochę słabsza charakterologicznie jest ta słaba płeć, tak, a trochę bardziej, powiedzmy, cierpliwy i wymagający będzie ojciec i na mniej sobie pozwoli niż mama" [M5].

Uczestniczący w badaniu rodzice uważali, że również same dzieci rozgraniczają macierzyństwo i ojcostwo, na przykład czując większy respekt wobec ojca, a matkę postrzegając jako osobę bardziej pobłażliwą, łagodną, czułą, do której można się przytulić. Dzieci wiedzą także, kto za co odpowiada, jeżeli jest podział ról - do matki zwracają się na przykład gdy chcą coś zjeść, umyć się czy ubrać, do ojca - gdy chcą się bawić. („Dzieci doskonale wiedzą, od kogo co egzekwować. Nie słyszałam, że, jak jesteśmy we dwoje razem, żeby któreś z nich powiedziało „tato, wlej mi pić”, nie, zawsze jest mama, „mama, chce siku”, „mama, chce pić”, „mama, podaj mi to, podaj mi tamto”. Natomiast tata, no to o samochodach z chłopakami, iść do samochodu tam coś pogrzebać, bardziej do zabawy chyba" [K5, FGI_1]). 
Jako specyficzną cechę macierzyństwa wskazywano poświęcenie. Część matek przyznawała, że teraz to dziecko stało się centrum ich zainteresowania, to o nim myślą w pierwszej kolejności, to dla niego rezygnują z własnych przyjemności: „tak naprawdę jest to cały czas podarowywanie czegoś dziecku, w takiej czy innej postaci, to jest ta gotowość do właśnie ciągłego takiego podarowywania" [K11]. Podkreślały jednocześnie, że ich poświęcenie nie oznacza, że ubolewają nad zejściem ich potrzeb na dalszy plan, ponieważ dziecko i spędzany z nim czas daje im dużo radości i satysfakcji: „Co to znaczy być mamą? To znaczy, no w momencie, kiedy się pojawia to dziecko to jest całkowite takie poświęcenie dla tego dziecka, ale to poświęcenie nie boli, bo to jest takie naturalne i zresztą to dziecko oddaje też swoją miłość i to też jest takie fajne" [K9]; „to jest świadome poświęcenie się, to jest świadomy wybór, ja nie cierpię, to nie jest zle" [K19]. Poświęcenie jako element roli matki zauważali także mężczyźni: „prawda jest taka, że więcej siebie poświęca matka niż ojciec po prostu, więcej traci tego swojego świata, który jest przed macierzyństwem" [M19]. Zwracali oni uwagę, że więcej obowiązków spada na kobietę, mimo że ojcowie starają się je wspierać i angażować w opiekę nad dziećmi. To jednak matki rezygnują z pracy zawodowej, zostając w domu z dzieckiem. Respondenci potwierdzali tym samym odtwarzanie tradycyjnego podziału ról. Jak pokazuje poniższy fragment dyskusji, w której uczestniczyli sami mężczyźni, zdaniem części badanych kobieta godzi się, by dziecko wypełniło cały jej świat i podporządkowuje mu inne sfery życia. Mężczyzna natomiast stara się po prostu włączyć rodzicielstwo do dotychczasowego życia, tak, by z niego jak najmniej zrezygnować.

M4: „Bycie matką” - poświęcenie, że faktycznie kobieta się poświęci całkowicie. Natomiast mężczyzna, może nie ma tu takiego, jest co prawda poświęcenie, ale bardziej takie pogodzenie.

M7: Poświęcenie u kobiety właśnie na każdej płaszczyźnie. Jest dziecko i jakby koniec, wszystko jest pod to dziecko.

M6: A facet szuka kompromisów bardziej.

M7: Tak, szuka kompromisów. Poświęci pewne rzeczy, ale nie wszystko. [...] bardziej cały ten świat u kobiety dziecko wypełnia. My jednak znajdujemy miejsce, mamy poczucie, że dziecko jest najważniejsze, ale pomiędzy sobą jakbyśmy się tutaj spotkali na piwie, czy coś, niekoniecznie byśmy o dzieciach rozmawiali.

[FGI_2]

Respondentki wyrażały przekonanie, że w pierwszym okresie życia dziecka matka powinna mu się całkowicie poświęcić, co nie oznacza jednak z rezygnacji z pracy zawodowej „na zawsze”: „Kobieta jest głównie po to, żeby to dziecko wychować, żeby jak najwięcej czasu wtedy poświęcać dziecku. Później, no w miarę oczywiście dorastania tego dziecka, te priorytety też się zmieniają, bo już chce się też zaistnieć zawodowo, już też chce się wrócić do pracy i mieć kontakt z ludźmi” [K3]. 
W wypowiedziach badanych osób na temat roli matki znalazło wyraz tradycyjne przekonanie o macierzyństwie jako życiowym posłannictwie kobiet. Respondenci określali je mianem ,spełnienia”, wskazując tym samym, że podjęcie roli matki jest warunkiem ,pełnej” kobiecości, wypełnienia roli kobiety. Uczestniczki badania uzasadniały taki sposób postrzegania macierzyństwa tym, że jest to ,rola naturalnie przypisana kobiecie", do której realizacji dąży się i przygotowuje całe życie, już jako dziewczynka poprzez udawanie ciąży i zabawę w mamę: „A ja myślę, że tu chodzi też o to, że, to jest zabawne, ale na przykład moja córeczka ma już dwoje dzieci w brzuszku. Kobiety mają to już od urodzenia wręcz, że to dziecko ma w brzuszku i że urodzi i że to spełnienie to jest właśnie może ten poród, nazwijmy to w ten sposób. No, bo wychowywać można nie tylko swoje dzieci, prawda, a tu ten moment, no nie wiem, ja rodziłam sama dwoje dzieci i dla mnie to po prostu było niesamowite wrażenie. Ja córkę jak urodziłam to ryczałam wręcz ze szczęścia. To jest to spełnienie” [K8_FGI_1]; ,Jednak ten stereotyp, że to kobieta raczej jest od tego, żeby rodzić dzieci, wychowywać je i że to jest jej najważniejsza rola. [...] Ja myślę, że to jest najprzyjemniejsza, ale również najtrudniejsza rola w ogóle do spełnienia dla kobiety bycie matką, prawda, i może dlatego to «spełnienie»" [K4, FGI_1]. Niektóre kobiety zauważały, że to poczucie spełnienia nie pojawiało się w momencie narodzin dziecka, lecz później, kiedy dziecko było większe, można się z nim już było komunikować, lepiej rozumieć jego potrzeby: „Dla mnie chyba teraz dopiero, jak ona już mówi, jak możemy się dogadać [...] teraz moje koleżanki, mają mniejsze dzieci, prawda, mogę doradzić, pochwalić się, prawda. To samo to, że się chwalę nią strasznie to już jest takie spełnienie, no po prostu..." [K6, FGI_1].

Na spełnienie kobiety w roli matki wskazywali nieco częściej mężczyźni (tabela 5). Taką definicję macierzyństwa uzasadniali, po pierwsze, większą potrzebą kobiet posiadania dziecka w porównaniu z mężczyznami [M2, M7, FGI_2], po drugie, odgrywaniem przez dziecko pierwszoplanowej roli w życiu matki, na co ona sama się zgadza i pozwala, by macierzyństwo zdominowało inne sfery jej aktywności. To dla badanych dowód na to, że kobieta spełnia się w macierzyństwie.

Rolę ojca jako warunek spełnienia się mężczyzny postrzegała tylko jedna z respondentek. Zdaniem uczestniczących w badaniu ojców, rodzicielstwo może być traktowane przez mężczyzn jako spełnienie, życiowa rola, ale nie od razu w momencie pojawienia się dziecka. Zwracali oni uwagę, że mężczyzna uświadamia sobie znaczenie i wartość roli ojca wraz z rozwojem dziecka, dojrzewa wraz z nim.

M6: Kobiecie to zegar biologiczny cyka i chce mieć to dziecko, a ojciec dopiero dostrzega tą przyjemność jak dziecko dorasta.

M1: U kobiet spełnienie, a u mężczyzn dorastanie. Po pewnym czasie jest to samo, dojdą do tego samego poziomu.

M7: Tak. To dorastanie też może się u faceta zmienić w spełnienie. No, ale jest najpierw takie dorastanie. [FGI_2] 
Takie późniejsze spełnienie się mężczyzn w roli rodzica zauważały także kobiety, wiążąc je z dumą i satysfakcją ojców płynącą z obserwowania efektów własnego wpływu na rozwój dziecka.

K6: Pewnie to spełnienie nastąpi po jakimś czasie, czyli jak to dziecko się już urodzi i on zacznie się nim zajmować.

K7: Oni są spełnieni, kiedy mają na przykład syna i, nie wiem, uczą go grać w piłkę.

K1: Widzą jego sukcesy. [FGI_1]

$\mathrm{Z}$ drugiej strony, jak zauważyła jedna z uczestniczek badania, w przypadku mężczyzn spełnieniem może być sam fakt zostania ojcem (rola biologiczna) i tym samym potwierdzenie męskości.

Kolejną różnicą między macierzyństwem i ojcostwem wskazywaną przez badanych jest inna relacja każdego z rodziców z dzieckiem. Zauważano, że więź ojca z dzieckiem buduje się później, przychodzi z czasem, podczas gdy matka natychmiast nawiązuje taką relację, co wiąże się z większą bliskością fizyczną z dzieckiem, samym okresem ciąży, potem karmieniem piersią, dłuższym czasem spędzanym z dzieckiem od samych narodzin. „Ta rola jest naturalnie przypisana kobiecie, a facet jednak musi w tę rolę bardziej wejść” [K1, FGI_1]; „Przynajmniej w przypadku facetów, przynajmniej w moim przypadku tak było, więź na pewno z dzieciakiem rośnie z czasem, jak on zaczyna jednak dorastać. [...] Właśnie, jeżeli są tu gdzieś różnice, to właśnie w tym, że matki rzeczywiście są od samego początku, od samego poczęcia, no czują, czują to w sobie. My tego nigdy nie poczujemy, można sobie opowiadać, ja wiem, że każdy ręką pewnie dotykał i patrzył jak kopie, ale to nie jest to, nie, mimo wszystko. [...] natomiast ja budowałem tę więź z dzieckiem” [M7, FGI_2]; „Znaczy na pewno matka ma tą przewagę nad ojcem, że ten taki kontakt fizyczny jest i to już przez ciążę i później kiedy karmi, bo najczęściej karmi, tak. No to jest na pozycji, że tak powiem, jeden, dwa poziomy wyższym niż mężczyzna, bo ma kontakt cielesny z tym dzieckiem. Co by nie mówić, uważam, i co by nie robić to matka początkowo przez te kilka pierwszych miesięcy jest w pozycji uprzywilejowanej mimo wszystko, lepszy kontakt ma" [M9]. Niektórzy wskazywali na różnicę w jakości relacji matki i ojca z potomstwem, wyjaśniając ją innym zaangażowaniem obojga rodziców w opiekę nad dzieckiem, mniejszą ilością czasu spędzanego z nim przez mężczyzn: „Moim zdaniem więź jest zawsze mocniejsza między dzieckiem a mamą niż między dzieckiem a tatą. [...] Może właśnie dlatego, że to mężczyźni są, nie rodzą dzieci i stąd. Że to nie mężczyźni przez pierwsze pół roku, czy rok wkładają w to maksimum swojego zaangażowania, w związku z tym, w tym czasie właśnie następuje ta więź, czyli to dziecko, które zaczyna jak gdyby poznawać świat, to w każdym momencie poznaje mamę, mama jest zawsze, tata pojawia się i znika" [M4]. 
Uczestniczący w badaniu ojcowie mówili o ,uczeniu się dziecka”, o konieczności „budowania relacji z dzieckiem”, która w przypadku matek powstawała „naturalnie”: ,[...] mężczyzna, prawda, no nie nosił, nie miał tego brzucha, nie karmił tego dziecka i rzeczywiście to jest jakoś inaczej to wszystko, on uczy się tego dziecka. Matka też się uczy, ale mężczyzna ma trochę jednak chyba mimo wszystko trudniejsze zadanie, bo to jest mniej naturalne niż dla matki" [M9]. Wskazywali tym samym na różne źródła więzi rodziców z dzieckiem: naturę - w przypadku relacji matki z potomstwem i kulturę - w przypadku relacji ojciec - dziecko. Mężczyźni podkreślali, że to od samego ojca zależy, czy nawiąże relację z dzieckiem, czy będzie miał z nim dobry kontakt: ,prawdą jest to, że facet musi trochę bardziej walczyć o to, bo oczywiście nie jest tak, że ja sobie będę tatą, który będzie stał obok mamy i wszystko zrobi się samemu, tutaj musi być duża inicjatywa, myślę ze strony ojca, który no chce nawiązać jakiś kontakt z dzieckiem" [M14]. Zarówno kobiety, jak i mężczyźni zauważali, że ten kontakt ojca z dzieckiem staje się intensywniejszy, gdy możliwa jest wzajemna komunikacja - dziecko zaczyna mówić, można nawiązać z nim rozmowę, „,dogadać się”: „Mąż się zajmował tym dzieckiem, ale kontakt taki rzeczywiście pojawił się w momencie, kiedy dziecko już tak się zaczęło bawić, już coś tam mówić. Tak, że rzeczywiście tak było, że on odczuł ten kontakt z dzieckiem, mąż” [K2, FGI_3]. Ze starszym, komunikatywnym dzieckiem możliwe są różne zabawy, w które mężczyźni chętnie się angażują: „Poza tym ta więź się buduje jak jest starsze, ponieważ, no nie ukrywajmy, mężczyzna jest jak dziecko czasami, i po prostu, jednak zabawy z dziećmi lepiej mu wychodzą" [M4, FGI_2]. Jak zaznaczył jeden z mężczyzn, opieka ojca nad dzieckiem w późniejszym okresie jego życia, gdy przestaje być niemowlęciem, należy do tradycji: „Coś w tym było, że u Słowian w czwartym roku życia chłopak szedł dopiero pod opiekę ojca, coś w tym było” [M7, FGI_2].

Macierzyństwo i ojcostwo, zdaniem badanych, różni się także podejściem kobiet i mężczyzn do rodzicielstwa, przejawiającym się w innym stosunku do dziecka (poza wspominaną wcześniej matczyną czułością i ojcowską surowością). $\mathrm{Z}$ ich wypowiedzi wyłania się tradycyjny obraz macierzyństwa jako podstawowej aktywności kobiety, w pełni ją absorbującej. Matki były przedstawiane jako osoby bardzo zaangażowane w opiekę nad dzieckiem, wszystkim się przejmujące, „latające za dzieckiem”, „przewrażliwione” i starające się kontrolować każdy szczegół jego życia: „Ja na przykład pilnuję, żeby, nie wiem, żeby Zosia zjadła całą miseczkę zupy. [...] matki po prostu, kobiety w ogóle jakoś bardziej tak podchodzą do tego emocjonalnie, tak bardziej się przejmują wszystkim, przywiązują wagę do różnych szczegółów. Przecież dziecko, tak naprawdę, jak nie zje raz całego serka, czy drugiego śniadania, to nic się nie stanie, prawda" [K4, FGI_1]. Zauważano, że mężczyźni nie przywiązują wagi do takich kwestii jak niedojedzony przez dziecko posiłek, „niewłaściwe” ubranko, nie dopatrują się w byle kichnięciu choroby, a w płaczu dziecka tego, że jest głodne. Ich zachowania określano jako „zdystansowane”, „,na luzie”. Kobiety zwracały także uwagę, że zabawy ojca 
z dzieckiem mają bardziej aktywny i partnerski charakter, podczas gdy one cały czas niepokoją się o dziecko, boją się, że się uderzy, zrobi sobie krzywdę itp. Rola ojca jawi się tu jako znacznie mniej obciążająca mężczyzn, którzy nie przejmują się drobiazgami, szczegółami, ale też nie pozwalają, by rodzicielskie obowiązki zdominowały ich własne potrzeby. Przejawia się to na przykład w spędzaniu czasu z dzieckiem w taki sposób, by sami ojcowie czerpali z tego przyjemność, czy łączenia zabawy z dzieckiem na przykład z oglądaniem meczu czy czytaniem gazety. Matki zauważały, że one starają się być tylko dla dziecka, poddają mu się, gdy ono chce się z nimi bawić, ojcowie natomiast „robią swoje” i przy okazji zajmują się dzieckiem.

Ta różnica między kobietami i mężczyznami w zaangażowaniu i stosunku do pełnionej roli rodzica wynikać może z innych, dostrzeganych przez badanych, społecznych oczekiwań wobec nich. Respondentki mówiły o odczuwanej społeczną presji na bycie dobrą matką, przejawiającej się w oczekiwaniu od nich karmienia dziecka piersią i świetnego radzenia sobie z obowiązkami rodzicielskimi od samego początku. Wskazuje to na trwałość tradycyjnego modelu macierzyństwa, tym bardziej że mężczyzn nakazy te nie dotyczą: „Po prostu wydaje się, że to jest oczywiste, że na kobiecie zawsze leży jakaś taka presja bycia dobrą matką i po prostu to jest jakaś taka obsesja, która cię nie opuszcza od samego początku i ja na początku byłam wystraszona po prostu, właśnie przez to, że jakoś tak nie szło z karmieniem, to od samego początku zaczynały się takie jakieś różne stresy, że no jak to w ogóle, nie potrafię jakoś tego karmienia ustawić, jakoś to nie idzie i jest takie odczucie, że właśnie matka powinna generalnie jakoś to wszystko wiedzieć i potrafić zrobić. [...] myślę, że mężczyźni są pozbawieni tego, takiego poczucia właśnie obowiązku bycia od razu dobrym i przygotowanym rodzicem. Natomiast jakby kobieta $z$ innym nastawieniem od razu wchodzi w macierzyństwo" [K11]; ,Z jednej strony rodzice, a zwłaszcza młoda mama jest strasznie zestresowana nową sytuacją, uważa, że powinna sprostać wszystkiemu, bo każdy ją sprawdza, czy sobie od samego początku ze wszystkim dobrze radzi. [...] Ja nie miałam pokarmu, więc byłam strasznie jakoś taka załamana. Jakoś czułam się taka gorsza, wiadomo. [...] ja chciałam wszystko robić przy nim sama, wydawało mi się, że właśnie muszę wszystkim udowodnić, że ja jestem taką dobrą mamą, że nikt mi nie musi pomagać, a tymczasem wydawało mi się, że wszyscy mnie krytykują" [K1].

Podsumowując przedstawione tu wyniki dotyczące macierzyństwa i ojcostwa, wpisanych w nie cech, zadań i społecznych oczekiwań, trzeba podkreślić dwojaki sposób widzenia ról rodzicielskich przez młodych wykształconych ludzi. Część badanych traktowała macierzyństwo i ojcostwo jako podobne, wręcz takie same role. Odnajdywali w nich wspólne aspekty, takie jak odpowiedzialność, zapewnienie dziecku bezpieczeństwa, wychowanie. Kwestionowali istnienie naturalnych różnic między kobietami i mężczyznami i uznawanie matki za ważniejszego w życiu dziecka rodzica. Odmienne zachowania obojga rodziców 
w stosunku do dziecka wyjaśniali uwarunkowaniami kulturowymi, nie biologią, unikając stereotypizacji ze względu na płeć. Ich przekonania oraz zachowania w roli rodziców odpowiadają nowoczesnemu modelowi płci.

W badanej zbiorowości znalazły się także osoby przekonane o odmienności macierzyństwa i ojcostwa, wynikającej z różnych cech, predyspozycji i umiejętności kobiet i mężczyzn. Wskazywano następujące różnice między matkami i ojcami:

- w podejściu do rodzicielstwa (poświęcenie się versus kompromisy),

- w podejściu do dziecka („przejmowanie się” versus zdystansowanie),

- w znaczeniu rodzicielstwa w życiu kobiety i mężczyzny (spełnienie versus dorastanie),

- w cechach matek i ojców (czułość versus surowość),

- w zadaniach matek i ojców wobec dziecka (pielęgnacja versus edukacja i dyscyplinowanie).

Odróżnienie macierzyństwa od ojcostwa badani uzasadniali nie tylko naturą kobiety i mężczyzny, specyfiką ich ról w procesie reprodukcji, ale także funkcjonalnością z punktu widzenia prawidłowego rozwoju dziecka. Tym samym racjonalizowali i sankcjonowali istniejący w ich rodzinach podział rodzicielskich zadań. Odtwarzany przez nich tradycyjny model rodzicielstwa traktowali jako właściwy i pożądany.

\subsection{Rodzicielstwo mlodych wykształconych Polaków - partnerstwo czy podzial ról?}

W tradycyjnym modelu płci role matki i ojca traktowane są jako zupełnie inne, opierające się na różnych rodzicielskich zadaniach oraz innej relacji z dzieckiem. Taki sposób rozumienia macierzyństwa i ojcostwa pociąga za sobą podział ról w rodzinie, uzasadniany naturalnymi różnicami między kobietami i mężczyznami. W nowoczesnym modelu płci propaguje się równość i partnerstwo oraz uzgadnianie, negocjowanie przez partnerów podziału obowiązków. Uwzględniając te wskaźniki tradycyjnego i nowoczesnego modelu płci oraz rodzicielstwa, na podstawie wyników badania można wyodrębnić następujące wzory ról rodzicielskich młodych wykształconych Polaków: nowoczesne, nowoczesno-tradycyjne oraz tradycyjne. Zostaną one kolejno omówione.

„Nowocześni rodzice” realizowali w swoich rodzinach partnerskie rodzicielstwo, rozumiane jako równe lub porównywalne zaangażowanie matki i ojca w zajmowanie się dzieckiem. W ich opisach tej sytuacji pojawiały się takie określenia jak „wspólna opieka nad dzieckiem”, „robota drużynowa”, „wymienność”, „partnerstwo”, „równouprawnienie”. Respondenci podkreślali, że oboje rodzice potrafią wszystko zrobić przy dziecku i mogą się wymieniać, zastępować nawzajem: „Natomiast jeżeli chodzi o takie czynności domowe, przy dzieciach, to 
u nas jest taka pełna wymienność, tak mi się wydaje” [M4]; „Ja bym to określił jako robotę drużynową, bez jakiegoś takiego podziału” [M13]; „Robiliśmy wszystkie rzeczy jakoś tak wymiennie [...] funkcjonujemy tak równolegle. Nie ma między nami przepaści, że on jest właśnie tylko i wyłącznie od tego" [K7]; „Ja mogę powiedzieć, że my od początku sobie postanowiliśmy układ partnerski i nie ma podziału obowiązków «ty robisz to, to i to, ja robię to, to, to». Jak ja jestem w domu, ja robię obiad, jak mąż jest w domu, mąż robi obiad, nie ma żadnego problemu. Jak było mniejsze dziecko, taki niemowlak, mąż je kąpał, ja ubierałam itd." [K2, FGI_3]. Z wypowiedzi badanych wynika, że zauważają oni zmianę modelu płci i rodzicielstwa, zwracali bowiem uwagę na zaangażowanie ojców w opiekę nad dzieckiem, uznając je za oczywiste i naturalne. Podkreślanie „naturalności” takiego zachowania mężczyzn dowodzi, że respondenci odrzucają tradycyjny model kobiecości i męskości. Ojcowie mówili o „braku oporu” wobec wykonywania pielęgnacyjnych czynności przy dziecku, o nieodczuwaniu lęku czy stresu, gdy zostawali sami z noworodkiem. Jeden z mężczyzn opowiadając o przewijaniu nowo narodzonego dziecka tuż po powrocie ze szpitala, zaznaczył: „Ja nie widziałem w tym nic zdrożnego” [M2, FGI_4]. Inny wspominał: „Jak dziecko się urodziło, to stało się częścią po prostu, żadnego oporu nie miałem. [...] czytałem dziecku, robiłem wszystko praktycznie, co było możliwe. Od małego się bawiliśmy, od małego chodzimy na basen. Zero stresu, zero problemów. To jest moje dziecko i opiekuję się swoim dzieckiem. Nic więcej” [M3, FGI_3]. Kolejny respondent zaznaczył, że „nie ma nic nagannego, złego” w wykorzystywaniu urlopu wychowawczego przez mężczyznę [M4, FGI_2]. Powyższy sposób mówienia o swoim rodzicielstwie przez badanych pokazuje, że w ich przekonaniu dla ojca $w$ tradycyjnym rozumieniu takie sytuacje były nie do pomyślenia, nie mieściły się w jego roli. Nowi ojcowie traktowali swój udział w opiece nad dzieckiem jako normę, nie chcieli by było to postrzegane jako coś szczególnego, wyjątek od reguły. Dawali tym samym do zrozumienia, że w ich przekonaniu nie ma już miejsca na tradycyjne ojcostwo. Zwracali uwagę, że dzięki zaangażowanemu rodzicielstwu mają dobry kontakt z dzieckiem: „Jeżeli mogłem [gdy dziecko było chore - K.D.-G.], to ja brałem urlop, siedziałem z dzieckiem i było fajnie, naprawdę fajnie, bo to był taki czas tylko dla mnie i dla niej. I właśnie poprzez to stawaliśmy się kumplami, bo byliśmy zdani na siebie, musieliśmy sobie radzić w jakichś trudnych sytuacjach" [M2, FGI_4].

Jednym ze wskaźników nowoczesnego modelu płci jest uzgadnianie podziału zadań między partnerami, negocjowanie „kontraktu płci” i niepowielanie gotowych schematów tylko dlatego, że „tak było zawsze”. Uczestnicy badania podkreślali, że podział obowiązków w ich rodzinach jest efektem umowy, wspólnej decyzji obojga partnerów, wspólnie wypracowanego rozwiązania: „W dzisiejszych czasach, kiedy kładzie się duży nacisk na jakieś tam równouprawnienie, to myślę, że to już nie jest ten model rodziny, że ojciec tyra gdzieś tam na budowie i zarabia na rodzinę, a mama zajmuje się domem. Znaczy to jest 
też kwestia umowy jakiejś, tak. Myśmy przyjęli układ partnerski. Wiadomo, że to nie jest tak, że każdy ma zawsze jakieś konkretne obowiązki. Różnie bywa. Wymieniamy się, pomagamy sobie" [M3]. Kluczową kwestią jest ustalenie, kto zostaje $\mathrm{w}$ domu $\mathrm{z}$ dzieckiem i przerywa zawodową aktywność. We wszystkich przypadkach zadecydowano, że będzie to matka, ale podkreślano, że zostało to wspólnie uzgodnione i że to nie jedyne możliwe rozwiązanie: „Ja myślę w ten sposób, że no przecież zdarza się tak, że tatusiowie się też zajmują dziećmi, więc wtedy czy jest ta mama czy tata, który musi się zająć takim małym szkrabem, to te obowiązki i wszystko inne jest takie same. Natomiast w takiej rodzinie jak nasza no to tutaj ten podział ról i obowiązków jest inny” [K12]; „Myśmy przyjęli, mamy ten model, że jest matka z dzieckiem i jest ojciec, który pracuje" [M12]; „Ja mam ten kontakt $\mathrm{z}$ dzieckiem, powiedzmy w pewien sposób naturalny ograniczony, ale to też była nasza decyzja, że żona $\mathrm{z}$ nim zostanie, a ja będę w tym czasie pracował, no żeby to jakoś zbilansować" [M1]. Respondenci zwracali uwagę, że podział obowiązków domowych i rodzicielskich jest uwarunkowany charakterem i czasem pracy obojga rodziców: „To często wynika z pracy, z podziału jakichś tam obowiązków zawodowych” [M7, FGI_2]; „Z racji tego, że do 16-17 jestem w pracy, no to się nie zajmuję [dzieckiem - K.D.-G.]. No, ale jak już jestem w domu no to czy tam przypilnuję, czy nakarmię, czy coś takiego. Wtedy żona odpoczywa i ja przejmuję obowiązki. Tutaj już na równej płaszczyźnie się zajmujemy. W ten sposób" [M2, FGI_2]. W sytuacji, gdy oboje partnerów pracowało zawodowo, badani starali się, by każde z rodziców miało możliwość spędzenia czasu z dzieckiem. Albo dzielili się i każde z nich kolejno opiekowało się dzieckiem, albo zajmowali się nim oboje, razem bawiąc się, czy wychodząc itp.: „U nas to jest tak, że my dużo rzeczy robimy wszyscy razem i jeśli wracamy z pracy do domu to już pojawiamy się oboje i ten czas w domu z dzieckiem staramy się, nie że jedno zajmuje się dzieckiem, drugie coś robi, tylko jednak mimo wszystko jakoś wspólnie. Jeśli gdzieś idziemy, nie wiem, na basen, na zjeżdżalnię, do piaskownicy czy coś, to też chodzimy we troje i wszyscy razem się bawimy” [K13]; „Gdy wracamy z pracy, to jest, ja się zajmuję na przykład obiadem, mój mąż opiekuje się dzieckiem, a potem mąż zmywa, ja zajmuję się dzieckiem, tak, że właściwie robimy tak, żeby każde z nas miało ten czas właściwie podzielony dla dziecka. Nie ma czegoś takiego, że tylko ja, tylko mąż. Tylko żeby to było, $\mathrm{i}$ ten jednakowy kontakt $\mathrm{z}$ dzieckiem, bo to jest według mnie bardzo ważne” [K1, FGI_3]; „Oboje pracujemy, prawda, ja i partnerka, tak że babcie i dziadkowie przejęli rolę opieki nad małą. Aczkolwiek sytuacja wygląda, nie tyle śmiesznie, ale, prawda, kiedy wracamy z pracy, to, no nie bijemy się o to, kto teraz będzie się dzieckiem opiekował, tylko się tym, prawda, dzielimy, żeby było sprawiedliwie" [M3, FGI_4]. W kilku rodzinach badani opiekowali się dzieckiem na zmianę, w związku z tym, że pracowali w różnych porach dnia. To jednak oznaczało, że sami mijali się i spędzali ze sobą mało czasu: „Ja byłam w domu, o ile można powiedzieć, przez 6 miesięcy, z tym, że później 
wymieniałam się z mężem po prostu, on pracował jednego dnia, ja drugiego dnia. Czyli dzień jakby dzieliliśmy sobie na połowę, on był do południa w pracy, a ja później, a on był z dzieckiem" [K1, FGI_4].

Wśród osób biorących udział w badaniu nie było przypadku wykorzystania urlopu „tacierzyńskiego” (części urlopu macierzyńskiego przez ojca)². Respondenci podkreślali jednak, że ojcowie w praktyce zostawali w domu po narodzinach dziecka, biorąc urlop wypoczynkowy. Dzięki temu mogli pomagać swym żonom w opiece nad dzieckiem zaraz po porodzie („No proszę pani, przecież to jest normalne, że jak się dzieciak rodzi to prawie każdy, jeżeli tylko może, to bierze urlop" [M7, FGI_2]). Jedna z par wykorzystała razem trzy miesiące urlopu wychowawczego. W dwóch rodzinach po urlopie macierzyńskim kobiety wróciły do pracy, a ojcowie zostali z dzieckiem, pracując w domu. Jeden $\mathrm{z}$ nich $\mathrm{z}$ tego powodu zmienił pracę i założył własną firmę: ,Ja sobie to bardzo cenię, to był jeden z celów tej mojej rewolucyjnej zmiany pracy, że mam kontakt stuprocentowy z małą od dnia urodzenia [...] To był jeden z celów tej całej operacji, żebym ja mógł się zajmować dzieckiem" [M15]. Ojcowie zaznaczali, że kiedy jest taka potrzeba, na przykład dziecko zachoruje, czy nie ma się nim kto zająć, biorą dni wolne lub urlop. Przyznawali, że najczęściej nie ma z tym problemu, ale to zależy od szefa i jego wyrozumiałości. Najlepiej, gdy sam przełożony ma dzieci. W stosunkowo komfortowej sytuacji znajdowali się mężczyźni, którzy pracowali w systemie zmianowym i mogli się z kimś zamienić lub którzy mogli wykonać pracę w domu, mogąc jednocześnie być z dzieckiem. Część mężczyzn deklarowało, że rozważali wzięcie urlopu wychowawczego i zostanie w domu z dzieckiem zamiast żony, ale decydujące tu było porównanie zarobków obojga rodziców. W sytuacji gdy mężczyzna zarabiał więcej lub wysokość wynagrodzeń była podobna, partnerzy podejmowali decyzję, że to matka zajmie się dzieckiem: „Ja po prostu zarabiam trochę więcej niż żona, więc trochę gorzej by było, jeśli ja bym został na urlopie, mimo że no nie mam takiego kontaktu z synem, na początku nie miałem, niż jakby żona miała iść do pracy. [...] Jeżeli te zarobki są z reguły... w miarę często są porównywalne, ta różnica jest nie tak duża, a szczególnie na niekorzyść kobiety, no to nie ma sensu, nie. Ale rzeczywiście, jakby moja żona zarabiała 4 razy więcej ode mnie, to nad czym by się tu było zastanawiać" [M2, FGI_2]. Ojcowie stwierdzali, że rezygnacja $\mathrm{z}$ pracy zawodowej i zostanie $\mathrm{w}$ domu $\mathrm{z}$ dzieckiem nie stanowiłoby dla nich problemu. Podkreślali, że nie przejmowaliby się ewentualnym negatywnym społecznym odbiorem tej sytuacji i żartami kolegów. Przyznawali jednak, że początkowo poradzenie sobie z wszystkimi obowiązkami byłoby dla nich trudne, poza tym musieliby „oswoić” z nową dla nich sytuacją. Należy brać pod uwagę, że były to dla badanych czysto hipotetyczne sytuacje (jak określił to jeden z ojców:

${ }^{2}$ W czasie realizacji badania (2007 r.) mężczyznom nie przysługiwał jeszcze urlop ojcowski; nie było także urlopu rodzicielskiego, który mogą wykorzystywać ojcowie. 
„mogę sobie to wyobrazić”), a deklaracje ,aktywnego ojcostwa” należały w zbiorowości respondentów do dobrego tonu. Na ile tego typu deklaracje przekładają się na rzeczywistość, pokazuje przypadek jednego z mężczyzn. Wspominał on, że mimo przekonania, że mógłby zajmować się dzieckiem, gdy doszło do podjęcia decyzji, kto wykorzysta urlop wychowawczy, przestraszył się i wycofał: „Do stereotypów jesteśmy tak przywiązani, że ciężko jest je przełamać. Mimo na przykład moich deklaracji wcześniejszych, że ja oczywiście, ja jestem dzielny, ale nie, ale nie dałem rady. [...] Zawsze o tym myślałem, że ja mógłbym, jeżeli byłyby różne zarobki, to tak, ale jak się okazało, no nie, to strach..." [M8, FGI_2]. Warto zauważyć, że chociaż wśród badanych nie znaleźli się mężczyźni korzystający z urlopu rodzicielskiego (poza wspominanym jednym ojcem, przebywającym trzy miesiące na urlopie wychowawczym razem z matką), to respondenci wspominali, że mają takich znajomych, w których kobieta i mężczyzna „zamienili się rolami” - ona wróciła do pracy i zarabiała na utrzymanie rodziny, a on opiekował się dzieckiem. Jednocześnie jednak samo określenie takiej sytuacji jako „odwrócenia ról” wskazuje na silny stereotyp podziału ról na kobiece i męskie.

Opowiadając o swoim rodzicielstwie, respondenci zaznaczali, że tworzenie jakichś odgórnych, sztywnych podziałów obowiązków, których się potem trzeba trzymać, nie ma sensu. Preferowali sytuację, w której daną czynność w domu czy przy dziecku wykonuje osoba, która akurat ma czas czy więcej siły. Zauważali, że niekiedy powstają konflikty wokół zadań, których nikt nie ma ochoty wykonać, ale szybko udaje się je załagodzić i porozumieć: „Jak ludzie są normalni to się samo układa. Czasami trochę zgrzyta, ale to musi zgrzytać" [M8, FGI_2]. Badani podkreślali, że biorą pod uwagę indywidualne preferencje i umiejętności każdego z partnerów, by każdy zajmował się tym, czym chce i z czym dobrze sobie radzi: „Znaczy niektórych podziałów jak gdyby po prostu się nie uniknąć, bo jedną rzecz ktoś robi lepiej a drugą ktoś gorzej. No, jeżeli ktoś nie potrafi gotować, to nie ma sensu, żeby męczyć jego i siebie i pozostałych członków rodziny" [M7, FGI_2]; „Myślę, że dzielimy się po połowie. Oczywiście, każde z nas jedną rzecz robi lepiej, drugie gorzej, ale chyba uzupełniamy się i to skutkuje" [M3, FGI_2]; „Ja się bardzo bałam przewinąc dziecko, a mój mąż zrobił to bez problemu” [K3, FGI_4]; „U mnie na przykład nie ma problemu, żeby mąż został z dzieckiem, dopóki dziecko nie zrobi coś więcej w pieluchę" [K2, FGI_4]. Na przykład kąpanie dziecka okazało się domeną ojców, na kobiety natomiast częściej spadał obowiązek przewijania i ubierania dziecka. Trudno jednak uwierzyć, że zmiana pieluchy dziecku należała do ulubionych czynności matek, a zatem wydaje się, że w wielu przypadkach uzgadnianie podziału obowiązków rodzicielskich polegało na określeniu, co mężczyzna może, chce i potrafi zrobić, by pozostałe czynności przejęła kobieta. Badani ci odwoływali się zatem do tradycyjnego modelu płci, w którym matkę traktuje się jako „głównego”, pierwszoplanowego rodzica, odpowiedzialnego za opiekę nad dzieckiem, a ojca jedynie jako jej pomocnika, angażującego się mniej lub bardziej w pełnienie rodzicielskich obowiązków. 
Przejawem nowoczesności w realizowanych przez uczestników badania rolach rodzicielskich było uznawanie wspólnego porodu za coś naturalnego, oczywistego, bezdyskusyjnego: „Nie było innej opcji” [M6]; „To było tak oczywiste, że absolutnie nie było nawet rozmowy, czy chcemy czy nie chcemy, to tak jak po wtorku jest środa, to taka bardzo oczywista była sprawa” [K12]; „,nawet nam przez myśl nie przeszło, że mogłoby to być inaczej” [M13]; „Mnie się wydaje, że nie pojawiło się nawet pytanie czy będziemy rodzić razem, zresztą to było wiadomo wcześniej, jak zaczęliśmy się starać o dziecko" [M15]. Młodzi rodzice często oboje uczestniczyli także w wizytach lekarskich, szkole rodzenia, traktując już ciążę jako wspólne doświadczenie, a nie sprawę kobiety. Potwierdzają to sformułowania, jakich używali respondenci: „zaszliśmy w ciążę” [M20]; „byliśmy w ciąży" [M15].

Zdaniem części badanych trudno mówić o partnerstwie i równości w rodzicielstwie, gdy matka zostaje $\mathrm{w}$ domu $\mathrm{z}$ dzieckiem, a ojciec pracuje zawodowo. Mimo przekonania o słuszności równego zaangażowania obojga rodziców w opiekę nad dzieckiem, respondenci ci w rzeczywistości realizowali tradycyjny model rodziny, opierający się na podziale ról ze względu na płeć. Stąd ich wzory rodzicielstwa określone zostały jako „nowoczesno-tradycyjne”, opierały się bowiem na nowoczesnych poglądach i tradycyjnych zachowaniach: „Uważam, że powinno tak być, że powinno to być na zasadzie partnerstwa i że robimy wszystko to, co należy do obowiązków, opieki nad dzieckiem i domem, że powinno to być jakoś wspólnie realizowane, a nie tylko spada na jedną osobę. [...] mój mąż znów pracuje bardzo długo, teraz akurat jest taki okres, że po prostu tej pracy jest mnóstwo i ja muszę sobie radzić ze wszystkim jakby sama. No on, kiedy może, to mi w tym pomaga, ale o dwudziestej drugiej to powiedzmy sobie szczerze rzadko cokolwiek jeszcze może zrobić, prawda. [...] ciężko jest podzielić te obowiązki. Po prostu one spadają na jedną bądź drugą osobę" [K3, FGI_4]. Sytuację taką określić można jako „partnerstwo nie do końca spełnione” lub „partnerstwo odłożone" (Warzywoda-Kruszyńska, Krzyszkowski 1990: 104), gdyż uczestnictwo kobiet i mężczyzn w życiu domowo-rodzinnym „wyrównuje się”, gdy oboje są aktywni zawodowo.

W rodzinach wszystkich badanych przez pierwsze miesiące życia dziecka kobiety przerywały pracę zawodową i zostawały w domu, wykorzystując obligatoryjny urlop macierzyński. Część kobiet wracała do pracy po jego zakończeniu (oraz wykorzystaniu dodatkowo urlopu wypoczynkowego, by przedłużyć czas opieki nad dzieckiem). Inne wykorzystywały urlop wychowawczy, zajmując się dzieckiem do momentu ukończenia przez nie roku, półtora czy dwóch lat. Następnie opiekę nad dzieckiem przejmowali najczęściej dziadkowie. Wśród badanych kobiet dominowało przekonanie, że ich aktywność nie powinna ograniczać się do domu i rodziny, wracały (bądź chciały wrócić) do pracy zawodowej, nie tyle ze względów finansowych, co ze względu na wartość pracy samej w sobie, chęć „wyjścia do ludzi”. Uczestniczki badania przyznawały, że decyzja o powrocie do pracy była bardzo 
trudna. $Z$ jednej strony odczuwały zmęczenie siedzeniem w domu, ograniczonymi kontaktami z innymi ludźmi, monotonią codziennych, tych samych obowiązków, z drugiej strony nie chciały zostawiać małego dziecka, obawiały się, że nie będą w stanie skoncentrować się na pracy: „To znaczy ja nie miałam, nie podejmowałam jakoś długo tej decyzji. Mówiąc szczerze, miałam jakieś takie wewnętrzne przekonanie chyba, że chcę wrócić do pracy. [...] kiedy synek się urodził, uznałam że podejmę decyzję możliwie późno jak się da, wtedy kiedy już będę musiała ją podjąć. [...] I nie ukrywam, że był to taki bolesny moment, bo zastanawiałam się, czy to będzie dobrze, to znaczy inaczej, nie potrafiłam sobie wtedy wyobrazić, jak wytrzymam w pracy, nie wiedząc, co się dzieje z dzieckiem, to na pewno" [K11]; „Ja uważam, że ciężko jest podjąć taką decyzję, ale trzeba się też kierować innymi rzeczami, nie tylko byciem $\mathrm{z}$ dzieckiem w domu, bo dla mnie akurat coś innego też się liczyło i powiem, że ciężko. Ale to jest właśnie na tej zasadzie, że trzeba trochę zaufać innym, tej osobie, z którą się zostawia dziecko" [K2, FGI_1].

Respondenci zauważali, że matki przebywające na urlopach macierzyńskich czy wychowawczych były, z racji pozostawania z dzieckiem w domu, bardziej obciążone obowiązkami związanymi z opieką. Zaznaczano jednak, że mężczyźni po powrocie z pracy ,przejmują" opiekę nad potomstwem. Z jednej strony, by kobiety mogły odpocząć i miały czas dla siebie, z drugiej, by dziecko miało dobry kontakt także z ojcem: „Jeżeli ja się zajmuję dzieckiem, wtedy, kiedy on jest w pracy, to ja chcę mieć chociaż tą godzinkę, dwie później dla siebie po południu. Żeby on się zajął tym dzieckiem, żebym ja mogła, czy nawet gdzieś wyjść, czy odpocząć, zwyczajnie, wziąć książkę i poczytać. [...] jeżeli mąż ma wolne, czy coś, to ja wtedy go bardziej jakby wyrzucam, żeby poszedł z dzieckiem na basen, czy... No jednak ten czas, żeby tylko on był i dziecko, nie to, że tam jeszcze córeczka, czy ja. Tylko on i dziecko" [K2, FGI_4].

Kobiety, które wykorzystywały urlop wychowawczy podkreślały, że świadomie zawieszały czasowo pracę zawodową, poświęcając się dziecku i cieszyły się, że mogły z nim spędzić ten czas: „Stwierdziłam, że właśnie teraz się skupię na opiece nad synem i że to będzie mój priorytet. [...] I powiem ci szczerze, że nie żałuję ani jednego dnia spędzonego z nim, mimo że, no nie jest, no nie jest łatwo. [...] Ten pierwszy rok ja naprawdę jestem w stanie dla niego poświęcić i naprawdę chcę to poświęcić dla niego. [...] To jest po prostu coś, co będzie procentowało w przyszłości” [K1]; ,Ja byłam z dzieckiem do półtora roku i uważam, że to były najpiękniejsze moje chwile spędzone z dzieckiem" [K2, FGI_3]. Respondentki zwracały jednak uwagę na bardzo krzywdzące stereotypowe postrzeganie kobiet zostających dłuższy czas w domu z dzieckiem jako „niepracujących”. Miały poczucie, że ich praca związana z wykonywaniem obowiązków domowych i opieką nad dzieckiem nie jest traktowana jako praca, że przez wiele osób są oceniane jako leniwe. Wreszcie, że uznaje się je za skoncentrowane na macierzyństwie i w związku z tym ograniczone, niemające żadnych innych zainteresowań i niepotrafiące rozmawiać o niczym innym niż dziecko i sprawy z nim związane: „Ludzie 
patrzą $\mathrm{w}$ ten sposób, że kobieta siedzi $\mathrm{w}$ domu z dzieckiem to jest nierób i leń po prostu. Bo jej się nie chce iść do pracy, bo woli sobie siedzieć, leżeć w łóżku. [...] Żadna praca, uważam, nie jest tak absorbująca, jak zajmowanie się dzieckiem i zajmowanie się domem. Ja naprawdę nabrałam dużego szacunku dla kobiet, które zajmują się domem. Kiedyś to były dla mnie kury domowe, które nie są w stanie zrealizować się zawodowo albo nie chcą, albo są leniwe, ale powiem ci, że teraz bardzo zmieniłam zdanie na ten temat i bardzo mnie boli, jeżeli domyślam się, że, bo wiadomo, że nikt mi tego wprost nie powie, jeżeli domyślam się, że ktoś mógłby tak o mnie pomyśleć” [K1]; „Raczej nie jest to doceniane i nie mówi się, że tak naprawdę osoba, która siedzi w domu i ma na głowie dziecko, obiad, dom, itd., itd., tak naprawdę też spełnia jakąś ważną rolę, prawda, i też wiele wysiłku w to wkłada i też powinna być bardziej doceniana" [K4, FGI_1].

Jak pokazuje zebrany materiał, mężczyźni biorący udział w badaniu doceniali i podziwiali swoje partnerki, które zostają w domu z dzieckiem i świetnie sobie radzą ze wszystkimi obowiązkami. Niektórzy z nich przyznawali, że nie zamieniliby się z nimi, bo to bardzo ciężka praca i nie wyobrażają sobie ogarnięcia wszystkich domowych spraw i robienia dzień w dzień tych samych rzeczy: „Ja nigdy bym się z żoną zamienił, bo to jest tak ciężka robota, że za żadne pieniądze by mnie do niej nie przekonał" [M1]. Pokazuje to fragment dyskusji, jaka wywiązała się podczas wywiadu fokusowego z samymi mężczyznami.

M3: Ja sobie nie wyobrażam jakbym miał iść na macierzyński.

M5: Na pewno byś miał kupę roboty.

M3: Kurczę, pranie, gotowanie, sprzątanie, jak tu się wyrobić?

M8: Ale zauważ, że rola gospodyni to jest jeden z trudniejszych zawodów.

M3: Moim zdaniem tak.

M8: Bo jak patrzę, to jest po prostu ciężka praca. Łatwiej jest z doskoku zrobić coś, nawet się uszarpać, niż dzień w dzień, systematycznie...

M3: Robić to samo.

M8: ...chociaż po trochu popychać jakieś sprawy, ale dzień w dzień no to to jest mistrzostwo świata.

M7: No na pewno, sam fakt, że... No, ale jak byś musiał, to byś zrobił. [FGI_1]

Ich niechęć do wykonywania obowiązków domowych i rezygnacji z pracy zawodowej na rzecz opieki nad dzieckiem pokazuje, że mimo deklarowanego poparcia dla partnerskiego modelu rodziny, w rzeczywistości preferują trady- 
cyjny podział ról, w którym mężczyźni są aktywni przede wszystkim w sferze publicznej, sferę prywatną zostawiając kobietom. W analizowanych rodzinnych układach częstą sytuacją było partnerstwo w odniesieniu do obowiązków rodzicielskich i jednocześnie jego brak, jeśli chodzi o wykonywanie prac domowych. Jak ujmowali to respondenci: ,[...] jeżeli chodzi o dziecko i czarną robotę przy dziecku, no to dziecko jest generalnie całość na pół. [...] przy gospodarstwie domowym, to na pewno Ania robi więcej i to dużo ode mnie, dużo, dużo więcej” [M5]; „Żona robi większość rzeczy, no bo mnie nie ma w domu, ona jest" [M16].

Trzeci - tradycyjny typ wzorów rodzicielstwa realizowały osoby przekonane o naturalności i konieczności różnicowania obowiązków matek i ojców. Respondenci obu płci mówili o zaobserwowanym w swoich rodzinach zjawisku niedopuszczania mężczyzn przez kobiety do opieki nad dzieckiem - „,bo one zrobią to lepiej i szybciej”: „A może to jest tak, że to kobiety ograniczają mężczyzn, nie pozwalając, przejmując na siebie wszystkie obowiązki i oni nawet gdyby chcieli, to nie mają szansy" [K8, FGI_1]. Jedna z kobiet, która kierowała się taką zasadą przy pierwszym dziecku, obecnie nastolatku, podkreślała, że był to błąd, że jej mąż potrafi świetnie zająć się młodszą, trzyletnią córeczką i odkrywa obecnie uroki ojcostwa, podczas gdy ze starszym synem ma bardzo ograniczony kontakt. Inna z matek przyznała, że doprowadziła do sytuacji, w której stała się więźniem własnego dziecka, które nie chciało opuścić jej ani na krok. Przekonanie, że uczestnictwo mężczyzny w rodzicielstwie zależy w dużej mierze od matki dziecka wyraził także jeden z respondentów: „W momencie kiedy mówimy o tym świecie matka - dziecko, no to oczywiście to jest taki mikroświat, ojciec to jest gdzieś tam jakiś taki satelita, wejść w ten świat matka-dziecko jest trudno. To wszystko zależy od tego, jaki jest charakter matki, czy zawłaszcza to dziecko, czy jest w stanie przepracować ten mechanizm, że «to jest ojciec tego dziecka, to jest mój mąż, ja nie zawsze sama mogę wszystko zrobić i fajnie by było, gdyby się między nimi więź wytworzyła». Jeżeli nie miałbym takiego wsparcia ze strony żony, no to byłoby mi bardzo trudno" [M6]. Mężczyźni zwracali uwagę, że problemem mogłoby być przekonanie matki, że to ona ma zostawić dziecko i wrócić do pracy na rzecz wykorzystania przez męża urlopu wychowawczego. Potwierdziła to jedna z respondentek, stwierdzając, że nawet przy wyższych zarobkach kobiety, niewiele z nich zdecydowałoby się zostawić dziecko z ojcem, bo jednak one ,po prostu czują, że to jest lepsze i dla niej i dla dzieci i dla męża" [K4, FGI_1]. Bardzo silny jest stereotyp, szczególnie wśród kobiet, co znalazło wyraz w zogniskowanym wywiadzie grupowym z samymi kobietami, że to matka jest tym ważniejszym, bardziej potrzebnym dziecku rodzicem w pierwszym okresie życia oraz że nikt nie zajmie się dzieckiem lepiej niż ona. Część uczestniczek badania nie wyobrażało sobie, żeby to mężczyzna mógł zostać z dzieckiem sam w domu - dziecko byłoby zadbane, ale w domu byłby bałagan, kobieta natomiast jest w stanie zająć się i dzieckiem i wszystki- 
mi innymi domowymi sprawami. Badane wyraziły przekonanie, że mężczyzna na urlopie wychowawczym wzbudzałby zdziwienie i śmiech u pracodawcy i kolegów, a także ich samych. Okazuje się, że stereotyp ojca zostającego w domu z dzieckiem przedstawia go jako osobę niemęską i leniwą. Pokazuje to poniższy fragment dyskusji:

K6: Ale faceci, dużo facetów się nie decyduje, bo są niemęscy wtedy. [...] Ale nawet taki facet idący do pracy do swojego szefa i mówi „szefie, chciałem iść na urlop wychowawczy”...

K1: Tak, jak ten szef popatrzy,

K6: ...to moim zdaniem, ten facet parsknie śmiechem. No bo tak jest. Jest mało który, co powie, „no fajnie, niech pan idzie”.

K4: Tyle, że na Zachodzie to jest popularne już w tej chwili.

K6: A u nas? Kolega się spyta „co robisz?” - ,jestem na urlopie wychowawczym” i cha, cha, cha. Nie, to jest po prostu to, że...

K7: Nie jest to popularne u nas.

K6: Ale ja sama z siebie naprawdę, mam różnych znajomych, jakby mi powiedział, że siedzi na urlopie, to ja bym się go spytała, czy mu się pracować nie chce. Bo dla mnie to jest...

K1: Bo taka byłaby nasza naturalna reakcja.

K6: Taka jest prawda. [FGI_1]

Kobiety zauważały, że przejmując wszystkie obowiązki związane z opieką nad dzieckiem doprowadziły do tego, że ich partnerzy niechętnie się później angażowali, odzwyczajali się od wykonywania pewnych czynności, „zapominali" na przykład jak się przewija dziecko czy przygotowuje dla niego mleko. Mężczyźni z kolei przyznawali, że wykorzystują tę „,nadgorliwość” kobiet, bo „skoro one to zrobią lepiej i nikt nie zrobi tego tak, jak one...”: „Zdarza się czasami tak, że panie mają to do siebie, że wydaje im się, że są w stanie rzeczywiście zrobić lepiej przy dzieciach, no nie? A my? No znowu powiem, że idziemy na pewną łatwiznę” [M7, FGI_2]. Jeden z respondentów obalał „mit” zaangażowanego, aktywnego ojcostwa, które jego zdaniem jest wyidealizowanym obrazkiem z reklamy telewizyjnej: „dziecko biegnie, a tata je podnosi na barana”. Większość według niego to ojcowie tylko „na papierze” - mało przebywający w domu, zapracowani: „Badania mówią, że tam, nie wiem, tata jest z dzieckiem średnio dwie i pół minuty dziennie, spędza, czy coś takiego. I tak jest naprawdę w praktyce” [M1]. Inna para cieszyła się, że córeczka „kojarzy” tatę, skoro tak rzadko go widuje, ze względu na jego absorbującą pracę zawo- 
dową [W9]. Niektórzy ojcowie przyznawali, że nie poradziliby sobie, gdyby musieli zostać sami z dzieckiem: „Na cały dzień to bym chyba nie został [sam z dzieckiem]. Nie umiem zmienić pieluchy" [M14]. Respondenci obu płci zauważali, że w ich rodzinach zajmowanie się dzieckiem przez ojca, ograniczone do dwóch godzin wieczorem i weekendów, polegało na zabawie z dzieckiem, ewentualnie wieczornej kąpieli. Mężczyźni opowiadali o swoim „niezaangażowanym” ojcostwie w następujący sposób: „Szczerze mówiąc, ja w ciągu tygodnia spędzam z nim tyle czasu, co mama spędza w ciągu jednego dnia. [...] W praktyce, tak jak mówię ze swojego doświadczenia, no ja jestem tatą przez półtorej godziny dziennie, no i jeszcze przez te parę minut jak zadzwonię w ciągu dnia i się pytam, jak się dziecko sprawuje. I to jest wszystko” [M1]; „A ojciec jest tak właśnie trochę $\mathrm{z}$ boku, taki zapewniający byt, itd., ale właśnie tak z boku i taka rola mi też tu przypadła” [M9]; „Rola matki jest główna, a ojciec jest wspierający" [M12].

Podsumowując, dla części młodych wykształconych Polaków partnerskie realizowanie rodzicielstwa jest czymś oczywistym i naturalnym. Dla części czymś pożądanym, ale trudnym do osiągnięcia w praktyce ze względu na nierówne obciążenie pracą zawodową. To matki są głównymi opiekunkami dzieci w pierwszym okresie ich życia. Mężczyźni wciąż rzadko korzystają z uprawnień dla pracujących rodziców, chociaż, i to może jest przysłowiowa pierwsza jaskółka zmian w tym zakresie, w większości dopuszczają do siebie myśl, że mogliby zostać $\mathrm{w}$ domu $\mathrm{z}$ dzieckiem, a żona wróciłaby do pracy. W badanej zbiorowości znalazły się także osoby kwestionujące ideę partnerstwa w rodzicielstwie. Jedne z nich preferowały tradycyjny podział ról w rodzinie: mężczyzna pracuje zawodowo, kobieta zajmuje się domem i dziećmi. Inne, choć nie popierały takiego podziału, były przekonane o odmienności roli matki i ojca przejawiającej się w różnych zadaniach związanych z opieką nad dzieckiem. W ich rodzinach ojciec nie wykonywał czynności przypisanych matce. Jak ujął to jeden z mężczyzn, zwracając się do żony: „Pilnujesz, żeby miała ubranka, pilnujesz, żeby była odpowiednio ubrana, ponieważ są pewne takie czynności pielęgnacyjno-higieniczne, które są po prostu na twojej głowie, ja w ogóle o tym nie myślę, bo to jest twoja domena, twoja wiedza, twoje doświadczenie" [M19].

Na podstawie zebranego materiału można wskazać dwa rodzaje uwarunkowań równego uczestnictwa obojga rodziców w zajmowaniu się dzieckiem. Możliwość realizacji partnerstwa w rodzicielstwie zależy, po pierwsze, od czynników, które określić tu można jako podmiotowe czy subiektywne, czyli chęci obojga partnerów do zaangażowania się i zaangażowania drugiej strony oraz ich przekonania, że takie partnerskie rodzicielstwo jest w ogóle możliwe; po drugie, od czynników zewnętrznych czy obiektywnych, związanych przede wszystkim $\mathrm{z}$ charakterem i czasem pracy każdego z partnerów. 


\subsection{Role matki i ojca $w$ rodzinach pochodzenia uczestników badania}

Jak zauważył A. Giddens, w warunkach późnej nowoczesności jednostki kwestionują gotowe wzory zachowań, nie chcą naśladować wcześniejszych pokoleń - w tym swoich rodziców, uznając je za przestarzałe, nieaktualne, nieprzystające do ich życiowej sytuacji. W badaniu podjęto zagadnienie odtwarzania - odrzucenia przez respondentów wzorów macierzyństwa i ojcostwa realizowanych w ich rodzinach pochodzenia. Pytano ich, na ile podobni są w pełnionych przez siebie rolach rodzicielskich do własnych rodziców, by ustalić genezę ich wzorów roli matki i ojca. Jak się okazało, we wspomnieniach respondentów z dzieciństwa główną figurą była matka, jako osoba zajmująca się nimi na co dzień: ,,[...] na pewno rola mamy była bardziej zdecydowana. Ojciec mniej nam poświęcał czasu” [K11]; „Cały dom był na głowie mamy, a tata nadawał się do czytania dzieciom, do chodzenia na spacery" [K20]. Ojców wspominano jako zapracowanych, ale mimo wszystko obecnych i dających się zapamiętać ze względu na organizowanie dzieciom wolnego czasu i różnych zabaw: ,ja owszem z ojcem, pamiętam wyjeżdżaliśmy gdzieś na wakacje, czasami mnie gdzieś zabierał, ale jakoś nie było tak, że on się mną zajmował” [M1]; „,mój tata też dużo pracował, [...] z tego bardziej świadomego okresu pamiętam mojego tatę, który bardzo starał się uczestniczyć w tym naszym życiu, właśnie spacery nie spacery, jakieś tam inne rzeczy, wymyślanie, jakieś wyjazdy pod namiot" [K1]. Wskazywano, że rolą ojca było przede wszystkim utrzymanie domu, a w stosunku do dziecka - spędzanie z nim wolnego czasu (którego miał niewiele) i organizowanie różnego rodzaju zabaw, wycieczek itp. Miłe wspomnienia czasu spędzanego z ojcem sprawiało, że sami badani odnosili wrażenie, że ten ich obraz jest „taki bardzo idealistyczny": ,ja pamiętam takiego mojego tatę, który odciążał moją mamę w ten sposób, znaczy ja to teraz wiem, że to na tym polegało, ale zabierał mnie na wycieczki rowerowe długie gdzieś tam, jakieś chodzenie po lesie, wspólne zabawy, jakieś tego typu historie, więc mimo wszystko mam takie bardzo dobre wspomnienia bycia wspólnego" [K6]. To opisywane przez respondentów ojcostwo można by określić mianem „ojciec od święta” i „od przyjemności”. Jeden z badanych zwrócił uwagę, że pamiętanie różnych wydarzeń z udziałem ojca świadczy o wyjątkowości, rzadkości takich sytuacji: ,pamiętam to przeżycie, to jest wspomnienie takie bardzo dawne, że jak mama mnie odprowadzała do przedszkola, to nie pamiętam w ogóle nigdy mamy odprowadzającej mnie do przedszkola, natomiast pamiętam jak tata mnie odprowadzał, więc zakładam, że to nie było aż takie częste" [M10]. Według jednej z kobiet, jej tata wychodzący z nią w wózku na spacery „był ewenementem" i wzbudzał sensację, a zatem w jej przekonaniu miała ona wyjątkowego ojca, mimo że podział ról w rodzinie był raczej „typowy” [K17]. Wspominano także, że ojcowie stawali się bardziej aktywni, gdy dzieci podrastały i stawały 
się partnerami w zabawie: ,[...] w tych pierwszych latach, to słabo podobno się mną zajmował. Natomiast później to był taki ojciec prawdziwy, ryby, rower, takie sprawy, pokazywanie różnych rzeczy, to na pewno" [M5].

Podkreślano zatem dobry kontakt $\mathrm{z}$ ojcem, a zarazem jego brak zaangażowania $\mathrm{w}$ codzienne obowiązki związane $\mathrm{z}$ opieką nad dziećmi. Z perspektywy czasu oraz własnych doświadczeń rodzicielskich uświadamiano sobie obciążenie matek, łączących macierzyństwo i prowadzenie domu z pracą zawodową: ,[...] jeżeli chodzi o opiekowanie się to z całą pewnością 98\% takich codziennych normalnych obowiązków spoczywało na mamie, mimo że ona pracowała i wcale nie siedziała na urlopie wychowawczym mając mnie, czy potem jeszcze mnie i siostrę. Ona gotowała, zajmowała się domem, ona robiła zakupy i tak naprawdę ojciec przez długi, długi naprawdę czas funkcjonował jako ktoś, kto wraca z pracy o tam godzinie, nie wiem 15 czy którejś, po czym rozkłada się na kanapie, mama serwuje mu obiad, serwuje mu kolację, sprząta i robi absolutnie wszystko. Jak mama w tym wszystkim funkcjonowała, to ja do tej pory nie wiem, nie wiem, bo nie umiałabym tego zrobić" [K7]. W odniesieniu do roli matki, jedna $\mathrm{z}$ respondentek podkreślała, że nie mogłaby jak jej mama poświęcić się całkowicie opiece nad dziećmi: ,[...] mama nie pracowała i ja nigdy nie chciałam tak robić, żeby siedzieć w domu i wychowywać dzieci. Chciałam być czynna zawodowo" [K2].

Niektórzy badani zauważali, że dopiero gdy założyli własne rodziny, zaczęli dostrzegać i rozumieć charakter relacji między rodzicami, do tej pory jej nie analizując i przyjmując taką, jaka jest. W jednej z rozmów, gdy mężczyzna oceniał ojca żony jako despotycznego, stwierdziła ona: „Tak, ale dla nas, dla nas jako dzieci, teraz możesz to inaczej odbierać, ale kiedy byłyśmy małe, to my tego nie widziałyśmy w ten sposób, jak widzimy to teraz, dla nas był tata, który miał swoje role, mama która miała swoje role i to wszystko się tam gdzieś zazębiało i nigdy nie miałyśmy problemu z rodzicami, oni ze sobą nie mieli problemów i my z nimi też, więc było po prostu zawsze dobrze, wszystko było na swoim miejscu" [K19].

Jedna z kobiet wskazywała na emocjonalny dystans między nią a ojcem, brak okazywania przez niego uczuć, mieszczący się w tradycyjnym modelu męskości: „mój tata raczej, taki typowy mężczyzna, taki mężczyzna bez uzewnętrzniania uczuć, absolutnie, oczywiście my zawsze z siostrą wiedziałyśmy, że nas kocha, itd., ale jakby, nigdy, jak był jakiś problem, to nigdy do taty" [K4]. Respondentka podkreślała, że jej mąż jest bardziej czuły i chętnie zajmuje się potomstwem. Z kolei on sam uznał, że swoją opiekuńczość wobec dzieci „odziedziczył” po matce: „Ojciec mój nie był aż tak zaangażowany. Nie, nie, to bardziej tak po matce. To mama była taka... nadopiekuńcza. Pewnie trochę i dobrze, że i po niej trochę przeszło na mnie, że ja trochę też. Bo ojciec nie, on nie był aż tak" [M4]. Także inni respondenci zauważali, są inni w stosunku do dziecka, mniej zdystansowani, bardziej zainteresowani dziećmi niż ich ojcowie [M9; M20]. Jeden z mężczyzn przyznał wprost, że jego ojciec był dla niego ,antywzorem”, jeżeli chodzi o relacje z dziećmi, w związku z czym, łatwiej mu ,zdefiniować lepszy wizerunek ojca” [M15]. 
Uczestnicy badania raczej odrzucali model rodziny panujący w ich domu rodzinnym, w dużej mierze tradycyjny, co przejawiało się w braku zaangażowania ojców w opiekę nad dzieckiem. Ten element, ze względu na zmianę właśnie w tym zakresie, był przez respondentów najbardziej zauważalny: „Ja nie powielam schematu ojca postępowania z nami, ponieważ ojciec jest cały czas gdzieś tam nieobecny, jest w pracy, zapracowany...” [M6]; „,mój ojciec jest osobą, która absolutnie nie pomagała, wręcz po prostu potrafił wyjść i zostawić ją [mamę] samą [...] [mąż] jest zaangażowany, widzę od razu, że jest inny niż mój ojciec" [K5]. Krytykowano także dominującą rolę mężczyzny w rodzinie pochodzenia: „Jak ja z perspektywy oceniam, że u nas role były też podzielone, natomiast ojciec dominował. Ja może widziałem pewne błędy takiego układu, dlatego staram się nie powielać tego we własnym domu” [M3]; ,[...] u mnie w domu jest taki patriarchat typowy, na pewno bym nie chciał tego powielać. [...] na pewno nie chciałbym no sprowadzać moje żony do takiej pozycji, na jakiej znajduje się moja mama, która zresztą pewnie jest na tej pozycji z własnego wyboru, ale mnie by się to nie podobało, taki układ" [M10]. Preferowanie partnerstwa znajdowało wyraz także w odrzuceniu modelu rodziny z dominującą kobietą: „,u mnie jest właśnie odwrotnie, u mnie rządzi moja mama, co też zupełnie mi nie odpowiada" [K10]. Jak stwierdziła jedna $\mathrm{z}$ respondentek, obserwowanie relacji w swojej rodzinie pochodzenia oraz rodzinie partnera ma na celu naśladowanie tego co dobre i unikanie sytuacji źle wspominanych czy źle ocenianych z dzisiejszej perspektywy: „No staramy się wziąć z naszych rodziców to co najlepsze i stworzyć swój związek, który będzie oparty na partnerstwie. U mnie była dominacja taty, u niego były jakby dwa oddzielne podmioty, trzeba jakoś tak wszystko to połączyć" [K19]. Wskazywano na odchodzenie od tradycyjnego podziału ról na rzecz wymienności i uczestnictwa obojga partnerów w domowych obowiązkach: ,[...] jest mniej wyraźny podział ról, takich tych standardowych ról, typ że kobieta to sprząta, zmywa, gotuje i wszystko inne, a mężczyzna, ściany maluje, naprawia kontakty itd. [...] natomiast tutaj, u nas jest to na zasadzie, dobra trzeba posprzątać, no to sprzątamy" [M13]. Jedna z par stwierdziła, że realizują podobny model rodziny jaki panował w ich domach, ze względu na to, że był on „,nietypowy”, tj. z ojcem zajmującym się domem i dziećmi:

K: Ale widzisz w naszych domach też to było zupełnie nietypowe i u ciebie i w moim domu.

M: No tak, u mnie w domu te role były zamienione o180\% i ojciec był w domu, ale wynikało to $\mathrm{z}$ tego, że był na rencie i był przez cały czas.

K: Tata mnie uczył jeździć na nartach, pływać, gdzieś mnie tam zabierał, coś mi pokazywał, później, tak jak mówiłam, lekcje ze mną odrabiał. [...] Różnie się życie układało, przez pewien okres mojej mamy w ogóle nie było, więc on przyjął na siebie rolę i matki i ojca, później też z tego jakaś większa więź między mną a ojcem niż między mną a mamą wynikała. [W13] 
Część respondentów zwracała uwagę, że trudno jest uciec od wzorów zachowań zinternalizowanych $\mathrm{w}$ młodości, że nieświadomie bądź podświadomie naśladują swoich rodziców, choćby tego nie chcieli: ,[...] że zawsze działałem w antagonizmie do ojca, bo się nigdy z nim nie zgadzałem, mieliśmy dużo różnych konfliktów. No a jak okazało się jak teraz już z nim nie mieszkam, jednak że tego ojca przypominam i to, moja żona mówi, w tych złych rzeczach” [M4]; „Oczywiście, każdy z nas ma jakaś swoją indywidualność itd. ale jednak podświadomie czy świadomie jakoś teraz bardziej czerpiemy z wiedzy i doświadczenia naszych rodziców, ewentualnie ich jakoś naśladujemy” [K1]; ,, jestem bardzo podobna do mojej mamy, nawet w takich kwestiach, których ja u mojej mamy nie cierpię i nie chciałabym się tak zachowywać, to tak się zachowuję" [K8]. Z drugiej strony podkreślali, że krytycznie oceniają swoich rodziców i starają się eliminować u siebie negatywne według nich cechy i zachowania: ,ja jakby zauważam błędy nawet w zachowaniu takim dotyczącym takich błahostek, w tym jak zachowują się moi rodzice nawet do tej pory i wydaje mi się, że ja taka nie jestem” [K5]; „Staramy się zauważać pewne niedociągnięcia i pracować nad tym, żeby pominąć je, żeby u nas w domu tego nie było. Ponieważ doświadczyliśmy tego na własnej skórze, naprawić te błędy zawczasu. Najlepiej żeby do nich w ogóle nie dopuścić” [M3]; ,ja już od bardzo dawna mam świadomość tego, co mi się w moich rodzicach bardzo nie podoba i ja z absolutną premedytacją staram się nie powielać ich zachowań" [K7].

$\mathrm{Z}$ wypowiedzi badanych wynika, że są oni nastawieni na „dzieci dobrej jakości”. Podkreślając swoje zaangażowanie i poświęcenie dla dziecka, dawali do zrozumienia (niekiedy wprost), że dawniej nie inwestowano tyle czasu, ale także pieniędzy, by zapewnić potomstwu jak najlepsze warunki rozwoju. Jak zauważyła jedna z respondentek: „Myślę, jak sobie to analizuję, że ja jednak jestem bardziej ukierunkowana na dzieci niż moi rodzice. Bo jak sobie myślę, to takie miałam niby, no miałam szczęśliwe dzieciństwo, bo rodzicom się nieźle wiodło i dużo miałam, ale wydaje mi się, że na przykład było ich stać na więcej niż mi zapewniali i dawali. Jakby nie stawiali tak na nas, nie inwestowali super w nas. Myślę, że ja w swoje dzieci więcej inwestuję, generalnie to wszystko w nich inwestujemy. [...] My jesteśmy tak bardziej skierowani na dzieci i wiesz, [...] wydaje mi się, że moi rodzice zawsze byli, ale nie byli aż tak strasznie zaangażowani" [K3]. Tę zmianę wyjaśniano także brakiem oferty różnego rodzaju zajęć, możliwości dla małych dzieci: „te czasy były też inne, na przykład teraz no to są właśnie takie typu tego, że nawet takie maleństwa się puszcza do jakichś tam grup zapoznawczych dzieci, czy na kursy tańca się wysyła, czy obcego języka uczy itd. i my myślimy o tym, że może byśmy chcieli, tak jak wspominałam, na przykład dziecko od trzeciego miesiąca na naukę pływania, no kiedyś to było nie do pomyślenia w ogóle" [K9]. Jedna z par, w której oboje partnerzy pochodzą ze wsi, zauważyła, że w wiejskim środowisku w czasach ich dzieciństwa, „dzieci się same wychowywały”: „A my jak przyjdziemy z pracy to cały czas poświęcamy dla Krzysia, bawimy się z nim, czytamy, chodzimy na spacer, cały czas jest dla Krzysia" [K2]. 
Ta chęć „odcięcia się” od rodziców, tj. życie po swojemu, według własnych reguł i zasad, przyjmowała niekiedy formę odrzucania ich pomocy w pierwszych dniach rodzicielstwa, w których, można byłoby przypuszczać, takie wsparcie mogło być bardzo przydatne. Respondenci podkreślali, że nie życzyli sobie porad, instrukcji, wskazówek, pouczania: „Wydaje mi się, że nasi rodzice też byli dość powściągliwi w udzielaniu jakichś tam rad, chyba wyczuwali, że my chcemy trochę tak po swojemu to wszystko zrobić [K11]; ,stworzyliśmy taki dystans do tych porad” [M11]; ,,my byliśmy dobrze przygotowani, myśmy nie potrzebowali w dużym stopniu jakiejś pomocy" [M15]. Pojawiły się opinie, że rodzice nie są autorytetem i wyrocznią w sprawach opieki i wychowania dzieci, że trzeba selektywnie podchodzić do ich rad: „rzeczywiście były takie rzeczy, o które pytaliśmy, natomiast no miało to znaczenie takie, że my nie traktowaliśmy ich jako jakiś Talmud, tylko dołączaliśmy je do tych opinii, które gdzieś tam zebraliśmy i sami podejmowaliśmy decyzję, więc sami ocenialiśmy po prostu czy to ma sens, czy nie" [M11]; „To jest pomoc, która jest momentami cenna, a momentami taka trochę trudna do przyjęcia, bo one [mamy] są znacznie mądrzejsze i wiedzą lepiej i w związku z tym mają tysiąc swoich pomysłów, no i tak trzeba się nauczyć tę pomoc jakoś selekcjonować i odrzucać” [K7]; „Myślę, że bardziej sami czytaliśmy różne rzeczy i bardziej chyba na wyczucie robiliśmy różne rzeczy niż tam radziliśmy się po rodzinie" [K5]. Można tu mówić o zjawisku profesjonalizacji rodzicielstwa - odwoływania się do wiedzy eksperckiej, co jest cechą nowoczesnego modelu macierzyństwa i ojcostwa (Urbańska 2009, 2012). Młodzi, wykształceni rodzice chodzą do szkoły rodzenia, kupują książki i czasopisma poświęcone ciąży, pielęgnacji i wychowaniu dziecka, wyszukują potrzebnych informacji w Internecie. Wiedza przekazywana z pokolenia na pokolenia traci na wartości, staje się jedną z wielu, nie jedyną, a ponadto budzi sceptycyzm i nieufność młodych ludzi. Wydaje się jednak, że w rezygnacji z pomocy rodziców najistotniejsza była potrzeba zachowania czy podkreślenia własnej niezależności, autonomii, samodzielności: ,,chcielibyśmy jednak robić to po swojemu” [K3]; „Mamy ten komfort i pełną swobodę działania, że praktycznie jesteśmy sobie sami sobie sterem, żeglarzem, okrętem. Na szczęście mamy pracę, z której możemy się utrzymywać, jesteśmy niezależni finansowo i decyzyjnie" [M3]. Świadczy o tym także poniższy fragment wywiadu:

K: Jak przyjechaliśmy, to nie było nikogo, byliśmy sami, ale później obie rodziny przyjechały, no i wieczorem już byli, jak było to pierwsze kąpanie, moja mama się zabierała, że to pierwszy raz, pierwszy dzień, to moja mama będzie pokazywać jak to trzeba robić, ale mąż zdecydowanie odmówił...

M: Nie, to moja robota, koniec. No w końcu jak się nie nauczymy od początku pewnych rzeczy to, to później już tego nie będzie, to już są stracone chwile, więc dlaczego dać sobie je odebrać. [W13] 
Podsumowując, na podstawie wypowiedzi uczestników badania można stwierdzić, że mają oni poczucie zachodzącej kulturowej zmiany w sposobie postrzegania i realizowania kobiecości i męskości, macierzyństwa i ojcostwa. Podkreślają oni pokoleniową różnicę, utożsamiając pokolenie swoich rodziców z tradycyjnym modelem płci i rodzicielstwa, od którego sami starają się odchodzić w swoich rodzinach i który, w ich przekonaniu, nie ma racji bytu. Niektórzy otwarcie krytykują patriarchalny charakter relacji między swoimi rodzicami, inni uznają, że tak po prostu musiało być, wskazując na zgodę obu stron na taki układ ról w rodzinie. $Z$ analizowanych wypowiedzi wynika, że najbardziej zauważalna i najistotniejsza zmiana, w odczuciu respondentów, dotyczy roli mężczyzny i ojca, która w założonych przez nich rodzinach polega na większym zaangażowaniu w domowe sprawy, a przede wszystkim w opiekę nad dzieckiem.

\subsection{Konkluzje}

Analizowane wzory macierzyństwa i ojcostwa świadczą o współwystępowaniu obok siebie elementów tradycyjnego i nowoczesnego modelu płci. Nowoczesność przejawia się tu w realizowaniu przez część badanych zasady równości w rodzicielstwie. Wśród nich były zarówno osoby traktujące macierzyństwo i ojcostwo jako podobne role, jak i osoby opowiadające się za równym, ale polegającym na innych zadaniach i relacjach z dzieckiem rodzicielstwem kobiety i mężczyzny. Przyjęty w rodzinach układ między partnerami - czy to oparty na ich wymienności, zastępowalności, czy też na podziale ról - był traktowany przez badanych jako efekt uzgodnień, ustaleń, wspólnej decyzji, a nie powielanie kulturowych konwencji czy schematów. W swoich wypowiedziach „nowocześni rodzice” wyraźnie odcinali się od tradycyjnego modelu rodziny, tradycyjnego podziału ról i stereotypów płci, podkreślając, że oni sami nie odtwarzają ich w swoich rodzinach. Jak ujął to jeden z badanych: „My tu mówimy o pewnych stereotypach. Ja mam takie wrażenie, że jest to związane z sytuacją pokoleniową. Pokolenie naszych ojców, matek i jeszcze wcześniejsze myśli właśnie w takim schemacie: matka, czyli osoba siedząca w domu, wychowująca dzieci, ojciec, czyli właśnie ten silny, ten, który ma zarabiać i utrzymywać rodzinę i jest czasem do zabawy z dziećmi. Natomiast myślę, że nasze pokolenie i pokolenia następne będą myślały już troszkę inaczej. Znaczy, ja myślę już trochę inaczej i mam wrażenie, że moi rówieśnicy myślą podobnie i to się będzie dalej przekształcało" [M2, FGI_4]. Z powyższej wypowiedzi wynika, że uczestnicy badania postrzegali siebie jako kreatorów zmian struktury, którzy nie reprodukują, a tworzą strukturę: nowoczesny model płci i rodzicielstwa. Świadczy o tym także krytyczna postawa wobec wzorów roli matki i ojca realizowanych $w$ rodzinach ich pochodzenia, odpowiadających tradycyjnemu modelowi kobiecości i męskości. 
Z drugiej strony, z wypowiedzi części badanych wynika, że za deklaracjami poparcia dla partnerstwa i równości w rodzicielstwie „,nie idą czyny”. Respondenci ci wskazywali na trudność czy niemożność osiągnięcia ich w swoich rodzinach, ze względu na ograniczenia wynikające $\mathrm{z}$ charakteru i czasu pracy zawodowej jednego z partnerów. Znalazła tu potwierdzenie teza Ulricha Becka, że „równouprawnienia mężczyzn i kobiet nie można zrealizować w strukturach instytucjonalnych, które zakładają ich nierówność". Możliwość wyboru sposobu pełnienia ról rodzicielskich była dla badanych tylko pozorna, bo ograniczały ich na przykład przepisy polityki rodzinnej oraz sytuacja na rynku pracy, powodujące, że korzystniejsza (ze względów finansowych) była rezygnacja matki z pracy zawodowej na rzecz opieki nad dzieckiem. A taka sytuacja prowadziła do odtworzenia w części rodzin tradycyjnego podziału ról. Kobiety nie protestowały przeciwko takiemu układowi, bo znajdowały w nim źródło władzy i swojej przewagi nad mężczyznami, co przejawiało się w zawłaszczaniu przez nie opieki nad dzieckiem i odrzucaniu sytuacji ,zamiany ról” (wykorzystywanie przez ojca urlopu wychowawczego). Tradycyjne wzory macierzyństwa i ojcostwa, oparte na podziale ról i w rezultacie nierównym zaangażowaniu matki i ojca w opiekę nad dzieckiem (większe obciążenie kobiet), uzasadniano i racjonalizowano, odwołując się do różnic między kobietami i mężczyznami.

Słowa komentarza wymaga język, jakim posługiwali się badani. Odwoływanie się przez nich do natury, instynktów, genów itp. świadczyć może z jednej strony o ich tradycyjnym podejściu do kobiecości i męskości, z drugiej strony o braku języka odpowiadającego nowoczesnemu modelowi. Zwróciła na to uwagę Iva Šmidová, analizująca wyniki swoich wywiadów przeprowadzonych z mężczyznami oraz obojgiem rodziców w Czechach (2008), nawiązująca w swojej interpretacji do koncepcji P. Bourdieu. Jej zdaniem ,język zawodzi” respondentów, którzy dysponują wyrażeniami językowymi z „dyskursu esencjalizującego", dominującego w codziennych rozmowach, ale także mediach, systemie edukacji itd. „Nie dziwi więc fakt, iż wyjaśnienia, legitymizacja i strategie uczestników prezentowanych badań szły w ślad za esencjalizacją jako jedynym dostępnym kodem językowym" (Bourdieu 1998 za: Šmidová 2008: 290). Autorka zauważa, że nawet osoby „dystansujące się od esencjalizacji”, posługują się takimi terminami „dla zachowania zrozumiałości oraz ze względu na brak (świadomości istnienia) lepszych rozwiązań” (Šmidová 2008: 291). Podobne zjawisko dało się zaobserwować w niniejszym badaniu. 



\section{Rozdział 8. Macierzyństwo i ojcostwo jako nowe doświadczenie kobiety i mężczyzny}

\subsection{Zostanie rodzicem jako przełomowy moment w życiu kobiet i mężczyzn}

Tradycyjny model kobiecości i męskości zawiera odmienne definicje macierzyństwa i ojcostwa. Różnice dotyczą nie tylko cech, zadań oraz rodzaju relacji z dzieckiem, ale także znaczenia roli rodzicielskiej dla kobiet i mężczyzn. Zakłada się, że rola rodzica $\mathrm{w}$ różnym stopniu ich angażuje, pozwala lub nie na łączenie $\mathrm{z}$ innymi sferami aktywności, zajmuje inne miejsce $\mathrm{w}$ hierarchii wartości itd. Socjalizacja przygotowująca do podjęcia tak zdefiniowanych ról powoduje, że rodzicielstwo może być inaczej doświadczane przez kobietę i przez mężczyznę. Warto więc przyjrzeć się bliżej zmianom, jakie wywołało w życiu badanych zostanie rodzicem. Materiał badawczy stanowily tu wywiady swobodne z parami rodziców. W zogniskowanych wywiadach grupowych, ze względu na specyfikę tej techniki oraz sytuację badawczą, nie podjęto problematyki macierzyństwa i ojcostwa jako nowego, indywidualnego doświadczenia.

Analiza wypowiedzi respondentów pozwoliła wskazać zarówno pewne podobieństwa doświadczeń kobiet i mężczyzn płynących z podjęcia po raz pierwszy roli matki/ojca, jak i zasadnicze różnice między nimi.

Do „wspólnych” doświadczeń, tzn. wymienianych zarówno przez matki jak i ojców, należały: zmiana w hierarchii wartości, odczuwanie braku wolności, trudność w planowaniu i organizacji czasu, ale także radość związana z rodzicielstwem, rekompensująca wskazane uprzednio ograniczenia i problemy. Zarówno matki, jak i ojcowie uczestniczący w badaniu podkreślali, że pojawienie się dziecka zmieniło ich życiowe „priorytety”. Dziecko stało się dla nich najważniejsze, weszło w centrum ich zainteresowań. Jak ujął to jeden z mężczyzn, opowiadając o zmianach spowodowanych narodzinami córki: „Teraz ona jest na piedestale, ona jest na pierwszym miejscu, wszystko robi się pod nią" [M2]. Inny z ojców mówił o wpływie posiadania potomstwa na każdy aspekt życia rodziców: „odkąd się Antoś pojawił, to nasze życie kręci się wokół niego. To jest jedyna oś w tym momencie wszystkiego. Bo wszystko jest mu podporządkowane. Nasz sposób spędzania czasu, to kiedy możemy ze sobą porozmawiać, bo kiedy Antoś ma zły dzień, no to my też mamy automatycznie zły dzień” [M1]. Podobnie opisywały takie przewartościowanie życia kobiety, wyjaśniając, że wynika ono z odpowiedzialności za dziecko oraz konieczności zaspokajania potrzeb dziecka w pierwszej kolejności: ,wszystko jakby się robi pod dziecko i dla dziecka” [K4]; 
„Człowiek jest sam, później pojawia się coś takiego małego, zakłóca tryb, który był dotychczas i trzeba poświęcać jemu czas, a nie sobie" [K1].

Młodzi rodzice obu płci zauważali, że posiadanie dziecka zmienia możliwości organizowania czasu i dysponowania nim. Część z nich zwracała uwagę, że posiadanie dziecka oznacza brak spontaniczności, „tej nieregularności, nieprzewidywalności" [M5], na którą można sobie pozwolić będąc tylko we dwoje. Respondenci podkreślali, że muszą wszystko odpowiednio wcześniej planować, żeby na przykład zorganizować opiekę nad dzieckiem, czy przygotować się do wyjazdu: ,już nie ma takich decyzji, a to jutro sobie pojedziemy nad morze, czy coś takiego, no nie można, to trzeba zaplanować, nawet wyjście gdzieś do pubu musi być zaplanowane, bo ktoś się musi nim zająć” [M6]; „Na przykład jest ciepła noc, to chodźmy na spacer, chodźmy gdzieś na piwo itd. To nie wchodzi w grę" [K5]. Stwierdzali, że tryb życia dziecka (stałe pory karmienia, kąpieli, spania itp.) wymusza określony „grafik” dnia i sprawia, że kolejne dni są do siebie bardzo podobne. W badanej zbiorowości znaleźli się także respondenci o zupełnie innych doświadczeniach dotyczących organizacji czasu. Ich zdaniem posiadanie potomstwa uniemożliwia planowanie. W ich odczuciach życie przestaje być „poukładane”, żyje się z dnia na dzień: „Trudno jest planować przy małym dziecku” [M2]; „Bo akurat kiedy coś sobie zaplanujemy, no to okazuje się, że dziecko jest chore albo nie mamy jej z kim zostawić” [K2]. „To naprawdę nie jest tak, że się planuje następny dzień, aha, że będę robiła coś, co bym chciała robić, tylko to jest takie, to się dzieje samo tak" [K5].

Inne ze wspólnych doświadczeń ojców i matek polega na tym, że dziecko nie tylko organizuje życie rodziców, ale także jest dominującym tematem rozmów. Niektóre pary przyznawały, że ich obecne grono przyjaciół i znajomych stanowią osoby same mające dzieci: „Zauważyliśmy z Małgosią, co mnie strasznie bawi, że my właściwie teraz możemy się spotykać tylko ze znajomymi, którzy mają dzieci albo którzy planują dzieci. Bo my o niczym innym nie rozmawiamy" [M1]; ,[...] w tym momencie nasze kontakty to są mama Kasia, mama Marysia, tata Tomek, tata Radek... [...] Jesteśmy w chwili obecnej na etapie wymieniania się informacjami, ile razy beknęło, jaka kupka..." [M6]. Powyższe wypowiedzi mężczyzn świadczą o tym, że przeżywają oni różnego rodzaju wydarzenia z życia dziecka podobnie intensywnie jak matki, mimo że ich dzień jest zdominowany przez aktywność zawodową, dostarczającą im wielu innych tematów do rozmów (ojcowie uczestniczący w badaniu nie rezygnowali z pracy zawodowej na rzecz opieki nad dzieckiem, jak ich partnerki). Ojcowie nie traktują zatem roli rodzica jako drugoplanowej wobec swoich ról w sferze publicznej, ale pozwalają jej być najważniejszą, absorbującą ich uwagę aktywnością.

Zarówno kobiety, jak i mężczyźni przyznawali, że trudno im wyobrazić sobie życie bez dziecka, że nie potrafią cieszyć się chwilami bez niego, bo im go brak, odczuwają pustkę: „Właściwie myśmy to zrozumieli tak naprawdę w momencie, kiedy zostawiliśmy kiedyś małą pierwszy raz na noc u rodziców i wróciliśmy do 
domu. I było ciężko. Cisza, milczenie, pusto w domu” [M2]; „Myśmy długo w sumie nie decydowali się na dziecko, nam się tak dobrze żyło, a teraz jak ona jest, to człowiek nie może sobie wyobrazić, że byliśmy kiedyś sami i żeśmy zwlekali, no i czemuśmy tak długo czekali na to, żeby się zdecydować, żeby się dziecko urodziło" [K9].

I matki, i ojcowie wspominali o ograniczeniu, czy wręcz braku wolności jako „naturalnej” konsekwencji zostania rodzicem i wspominanego wcześniej zdominowania życia przez dziecko. Mówiono o niemożności znalezienia chwili dla siebie, „uwolnienia się” od dziecka: „My sobie nie możemy w weekend tak wyjść, tak jak wcześniej wychodziliśmy [...] No bo było wiadomo, że jeśli gdziekolwiek się ruszymy, to tylko z nią, a jak z nią, no to wiadomo, że o ósmej kąpiel, spać i do widzenia" [K7]. Pojawienie się tego wątku w wypowiedziach rodziców obu płci świadczyć może o podobnym „obciążeniu” obowiązkami związanymi z opieką nad dzieckiem i odpowiedzialnością za nie.

Innym wspólnym dla obojga rodziców doświadczeniem jest poczucie zmęczenia, wynikające z mniejszej ilości snu, większej liczby obowiązków, stresu związanego z odpowiedzialnością za dziecko. Mówiono o braku możliwości odpoczynku, bo opieka nad dzieckiem wymaga pełnej, 24-godzinnej gotowości: „Córeczka miała może ze dwa tygodnie i tak sobie pomyślałam, że jestem taka zmęczona [...]. Boże, kiedy ja teraz odpocznę” [K8]; „Dziecko, wiadomo, zajmuje cały dzień i człowiek jest tak zmęczony już wieczorem, jakby pracował nie wiadomo ile" [K4]. Zwracano uwagę na trudne początki rodzicielstwa, gdy trzeba przywyknąć do nowej roli, innej organizacji dnia, wdrożyć się w obowiązki, itp. - „[...] później się zaczęło zmęczenie, jak się urodził syn. Taka ogromna radość, nerwy, a później ogromny wysiłek. To wpływa na życie rodzinne, trzeba się zupełnie przestawić do nowej sytuacji” [M10].

Zarówno wśród pytanych kobiet, jak i wśród mężczyzn znalazły się osoby, które podkreślały, że chociaż ze względu na dziecko trzeba zrezygnować z pewnych rzeczy, czy je ograniczyć, to dziecko to rekompensuje, dając wiele radości i szczęścia: „No i jeszcze wszelkie niedogodności, jakiekolwiek, jakie tutaj wymienialiśmy, czy rezygnacje $\mathrm{z}$ czegokolwiek, takie dziecko jest w stanie załatwić naprawdę jednym uśmiechem czy jednym przytuleniem się. I to wszystko odchodzi w niepamięć i o tym w ogóle się nie myśli, że z czegoś trzeba było zrezygnować i to jest najfajniejsze” [M7]; „Mimo to że to było wyczekane dziecko i zaplanowane itd., to jednak czasami mi było trochę szkoda, że na przykład znajomi gdzieś tam sobie idą i mają jakąś imprezę [...] ale znowu z drugiej strony dziecko to wynagradza bardzo, bo sprawia tyle radości, że to jest niesamowite" [K7]. Jak określiła to jedna z mam [K3], bycie rodzicem wiąże się z ,osobistym rozdarciem" między potrzebą odpoczynku od dziecka i związanych z opieką nad nim obowiązków a chęcią bycia z nim cały czas i tęsknotą w momencie rozłąki.

W wypowiedziach rodziców obu płci pojawiły się także wątki dotyczące specyficznych dla kobiet i mężczyzn doświadczeń związanych z rodzicielstwem. 
Specyfika macierzyństwa, wynikająca z faktu większego obciążenia kobiet opieką nad małym dzieckiem i zawieszenia pracy zawodowej na czas urlopu macierzyńskiego, znalazła wyraz w innym doświadczaniu upływu czasu. Respondentki stwierdzały, że czas płynie inaczej, gdy się jest z dzieckiem. Co ciekawe, jedna $\mathrm{z}$ badanych odczuwała to jako spowolnienie czasu, druga - jego przyspieszenie: „Ten mój cały czas z nią jest taki spowolniony, chcę to sobie pójdę na spacer, pada deszcz to nie pójdę na spacer, albo pójdę później, albo coś przełożę. [...] mimo wszystko ten dzień jest taki bardziej luzacki, ja wiem, że mi się nie spieszy [...]. I to wszystko jest takie rozciągnięte w czasie” [K7]; „Jak pojawia się dziecko, no to ten czas, czas przede wszystkim płynie bardzo szybko, bo jest pora jedzenia, pora kąpania, pora spania, pora usypiania, poobiedniej drzemki, tak że mało jest czasu dla siebie" [K2]. W odniesieniu do badanych ta różnica doświadczeń związana była z koniecznością godzenia opieki nad dzieckiem z pracą zawodową $\mathrm{w}$ drugim przypadku, podczas gdy pierwsza $\mathrm{z}$ kobiet $\mathrm{w}$ momencie przeprowadzania wywiadu była na urlopie wychowawczym, a zatem jej aktywność ograniczała się do sfery domowo-rodzicielskiej. Kobiety zwracały także uwagę na monotonię codzienności: „Te wszystkie dni takie się robią podobne do siebie, dziecko co dwie godziny je, to jest tak uregulowany tryb życia i tak się w to wdrażasz, że po prostu ja nie pamiętam poszczególnych dni. Po prostu jest to jakiś tam okres, gdzie on jadł, spał, jadł i spał. I właściwe to wszystko" [K5]. Młode matki doświadczały nie tylko wspominanego zmęczenia fizycznego, w związku z pełnieniem obowiązków rodzicielskich (odczuwanego również przez mężczyzn), ale także zmęczenia „siedzeniem w domu”, powtarzalnością czynności. Mówiły o potrzebie zmiany, „wyjścia do ludzi” i powrotu do pracy zawodowej: „Miałam ochotę już, żeby coś nowego się pojawiło, żeby nie spędzać tylko całego dnia z dzieckiem. Chciałam coś nowego” [K4]; „Te pierwsze miesiące było fajnie, ale z każdym następnym już naprawdę coraz gorzej mi się tu siedziało z nim, ze względu na to, że to było cały czas to samo, więc bardzo chętnie wróciłam do pracy, powiem szczerze, bardzo chętnie" [K6]. Takie uwagi nie pojawiały się z oczywistych względów u mężczyzn, którzy nie opiekowali się małym dzieckiem 24 godziny na dobę przez dłuższy czas. Tylko dwóch badanych zostało w domu z dzieckiem po upływie urlopu macierzyńskiego i powrocie kobiety do pracy, jednak w swoich wypowiedziach nie zwrócili uwagi na przedstawione powyżej odczucia, o których mówiły kobiety. Być może wynika to z tego, że ojcowie ci nie mieli poczucia pełnego poświęcenia się dla dziecka, gdyż prowadzili własną działalność gospodarczą, a więc będąc w domu łączyli pracę z opieką nad dzieckiem.

$\mathrm{Z}$ wypowiedzi badanych wynika, że wspominane wspólne doświadczenie braku wolności oznaczało co innego dla matek i ojców. W życiu mężczyzn przejawiał się on przede wszystkim w konieczności rezygnacji ze spotkań towarzyskich, wyjść wieczorami itp. - „Rzadziej się spotykamy ze znajomymi. Nie pojedziemy na przykład z nimi na działkę, żeby siedzieć całą noc, gadać i pić wino" [M5] „Kończą się jakieś wyjścia, tzw. lansowanie się na mieście, wyjście gdzieś 
wieczorne mało wchodzi w grę, no chyba, że zostaje babcia” [M8]; „Musiałem zrezygnować chociażby z chodzenia na siłownię, [...] z wychodzenia gdzieś na miasto" [M3]. Natomiast kobiety mówiły o pewnym zniewoleniu, przywiązaniu do dziecka, związanym z karmieniem piersią, uniemożliwiającym „wyrwanie się" z domu na dłuższy czas - „Te pierwsze miesiące były takie, że co dwie godziny karmienie i taka, takie przywiązanie maksymalne do syna, nawet jak gdzieś tam wyszłam sobie, to wiedziałam, że zaraz muszę koniecznie wrócić, bo będzie chciał jeść" [K6].

W związku z wykorzystywaniem obligatoryjnego urlopu macierzyńskiego przez matki pojawienie się dziecka powodowało przerwę w aktywności zawodowej kobiety. Niektóre respondentki przyznawały, że mają poczucie, że coś tracą: „Moja decyzja o macierzyńskim, wychowawczym, jednym i drugim dziecku nie do końca jest podyktowana moją jak gdyby... moją ambicją i nie jest to dla mnie jakoś super korzystne. Ja w zawodowych relacjach więcej tracę niż zyskuję, ale biorąc pod uwagę właśnie te dzieci, to ja robię to dla nich, żeby się razem chowały, żeby była ta mała różnica wieku itd., więc ja robię to dla nich, nie robię tego dla siebie" [K19]. Mówiły o obawach związanych z powrotem do pracy, odnalezieniem się na nowo w zawodowym środowisku: ,[...] wiadomo, tam w pracy się pozmieniało, jakieś różne inne rzeczy były wprowadzane, itd. Ja już nie mówię nawet o tym, że się traci, jeżeli chodzi o pieniądze też, bo wiadomo przez rok cię nie ma w związku z czym ty stoisz w miejscu, a inni idą do przodu. Ale przede wszystkim tego, jak ja się tam odnajdę" [K9]. Kobiety zawieszające na jakiś czas aktywność zawodową i ,poświęcające się" roli matki mówiły o odczuwanym totalnym zdominowaniu ich życia przez macierzyństwo: ,jak przychodzą znajomi, to wszyscy rozmawiają o pracy, a ty nie masz o czym rozmawiać, bo ty masz dziecko, pampersy, książeczki jakieś dla dzieci, nic więcej, a tu każdy żyje życiem zawodowym i znajomymi, a ja żyję tylko dzieckiem" [K4].

$\mathrm{W}$ wypowiedziach mężczyzn pojawiały się z kolei refleksje na temat wpływu bycia ojcem na ich pracę zawodową. Jeden z ojców wspominał trudności w pracy zaraz po narodzinach dziecka, ze względu na zmęczenie i niewyspanie: „Ten pierwszy okres jest na pewno trudny, bo to są nieprzespane noce, trzeba pracować, no żona akurat te trzy miesiące pierwsze była na urlopie macierzyńskim, natomiast no ja nie. [...] w nocy trzeba było wstawać do dziecka, więc było to na pewno jakieś obciążenie, człowiek w pracy się gorzej koncentruje" [M11]. Badani mówili o ograniczonej dyspozycyjności, unikaniu zostawania w pracy po godzinach czy też pracowaniu dłużej jednego dnia, żeby móc wyjść wcześniej innego dnia: „Muszę po prostu troszeczkę więcej z siebie w niektórych dniach dać firmie, po to, żeby móc mieć po prostu podkładkę do tego, że następnego dnia wychodzę wcześniej, bo idziemy z dzieckiem na szczepienie czy do lekarza" [M8]. Jak zauważył jeden z ojców, posiadanie dziecka zwiększyło jego wydajność pracy - stara się szybko uporać się ze wszystkimi zawodowymi sprawami, żeby jak najwcześniej wrócić do domu, do dziecka. 
Podsumowując, na podstawie analizy doświadczeń badanych, można stwierdzić że zostanie rodzicem jest punktem zwrotnym nie tylko w życiu kobiety, ale także w życiu mężczyzny. Pojawienie się dziecka pociąga za sobą różnego rodzaju zmiany, jak zmianę hierarchii wartości, organizacji dnia, możliwości decydowania o sobie czy poczucia wolności. Doświadczenia matek i ojców były często bardzo zbliżone, zwracali oni uwagę na podobne aspekty, nasuwały im się te same refleksje. Odczucia mężczyzn świadczą o tym, że nieaktualne jest w ich przypadku tradycyjne przekonanie, że rola ojca jest czymś mniej znaczącym niż rola matki w życiu kobiety. A zatem różnica $\mathrm{w}$ intensywności zaangażowania $\mathrm{w}$ opiekę nad potomstwem (to matki zostawały w domu z dzieckiem w pierwszym okresie jego życia) kobiet i mężczyzn nie powodowała diametralnych różnic w sposobie odczuwania zmian.

Z drugiej strony, część wypowiedzi wskazuje jednak na specyficzne doświadczenia macierzyństwa i ojcostwa, wynikające z innej formy łączenia pracy zawodowej z rodzicielstwem przez kobiety i mężczyzn. Matki zawieszały na jakiś czas aktywność pozadomową na rzecz całkowitego często poświęcenia się dla dziecka. To one więc wspominały o zmianach w doświadczaniu upływu czasu („czas inaczej płynie”) oraz narzekały na monotonię dni spędzanych z dzieckiem w domu. Mężczyźni z kolei mówili o wpływie posiadania dziecka na wykonywanie przez nich zawodowych obowiązków. Na tej podstawie można jednak stwierdzić, że odmienność doświadczeń jest uwarunkowana nie tyle płcią rodzica, co tym, czy poświęca on w pełni swój czas dziecku, czy też jest jednocześnie aktywny zawodowo. Dostrzegali to sami badani, porównując ze sobą rolę matki i ojca i wskazując, że fakt większego zaangażowania w rodzicielskie obowiązki jednego z nich (częściej matki) wynika jedynie z tego, że jest ono mniej obciążone pracą zawodową, co z kolei jest efektem ich wspólnej decyzji.

\section{2. „Jestem matką", ,jestem ojcem” - kobiety i mężczyźni o zmianach w sposobie postrzegania siebie}

W przystosowywaniu się do nowej roli - tu roli rodzica - mamy do czynienia $\mathrm{z}$ dwoma procesami: $\mathrm{z}$ jednej strony jednostka dokonuje reinterpretacji roli społecznej (tworząc własną koncepcję roli), z drugiej strony zachodzi modyfikacja ,ja” (Breen 1975: 9, za: Budrowska 2000: 383). W badaniu poza ogólnymi, „życiowymi” zmianami doświadczanymi przez kobiety i mężczyzn, związanymi z pojawieniem się dziecka, respondentów pytano także o ewentualne zmiany w postrzeganiu siebie po wejściu w nową dla nich rolę rodzica. Interesowało nas, czy dostrzegli w sobie jakieś zmiany, na przykład odkryli w sobie cechy, które wcześniej nie miały okazji się ujawnić, czy coś ich zaskoczyło w nich samych, kiedy zostali rodzicami. 
Jak się okazuje, kobiety nieco częściej niż mężczyźni stwierdzały, że żadnych takich zmian u siebie nie zaobserwowały: „Wiesz co, ja mam dwóch braci i każdy $\mathrm{z}$ nich ma dziecko, więc no miałam już ten kontakt $\mathrm{z}$ dzieciakami. Tak naprawdę to żadnych jakichś tam niespodzianek w swojej osobowości nie odkryłam. Tak, że spodziewałam się, że będę taką mamą a nie inną" [K8]; „Ja byłam przygotowana na bycie mamą. Bardzo chciałam mieć [dzieci], bardzo się cieszę, że je mam i nie zauważyłam, żeby coś się we mnie zmieniło" [K5]. Jednocześnie te badane, które dostrzegły w sobie jakieś zmiany, miały więcej niż mężczyźni przemyśleń na swój temat, obserwowały w sobie więcej zmian. Być może jest to związane z tym, że spędzały one najczęściej więcej czasu z dziećmi, miały więc więcej okazji do „samoobserwacji” w relacji z dzieckiem.

Podobnie jak w przypadku omawianych wcześniej doświadczeń zmian w życiu po wejściu w role rodzicielskie, także $\mathrm{w}$ odniesieniu do zmian $\mathrm{w}$ postrzeganiu siebie można wskazać podobieństwa oraz różnice między kobiecymi i męskimi doświadczeniami.

Jedną z cech, których pojawienie się, czy ujawnienie po zostaniu rodzicem zauważyli i ojcowie i matki, była cierpliwość. Badani przyznawali, że nie spodziewali się, że dziecko „nauczy ich” cierpliwości, sprawi, że dotąd nerwowi, staną się bardziej wyciszeni i spokojniejsi: ,[...] uważam, że mam więcej cierpliwości niż myślałam, że będę miała. [...] pokłady cierpliwości, jakie są dla własnego dziecka to jest jakiś szok" [K20]. W wypowiedziach respondentów obojga płci pojawiły się także uwagi na temat zejścia na dalszy plan egoistycznych pobudek, myślenia w pierwszej kolejności o potrzebach dziecka, a nie własnych czy partnera. Ojcowie i matki biorący udział w badaniu zauważyli u siebie zwiększenie wrażliwości na krzywdę i cierpienie doznawane przez dzieci (nie tylko własne) oraz chęć niesienia pomocy. Jeden z mężczyzn przyznał, że bezbronność małego dziecka wywołuje u niego potrzebę ,natychmiast zrobienia wszystkiego co tylko możliwe, żeby mu pomóc" [M6]. Inni zauważali, że bardziej zwracają uwagę na informacje o krzywdzie wyrządzonej dzieciom i są nimi poruszeni: ,zdecydowanie dużo większa empatia z tymi innymi dzieciaczkami, na pewno więcej uwagi się temu poświęca" [M9]. Obserwowały to u siebie także kobiety: ,[...] teraz jak mam własne dziecko, to autentycznie jeżeli oglądamy film i jest pokazane, że coś temu dziecku robią, to przełączamy, bo nie możemy tego oglądać. Wiesz, to od razu odnosisz do swojego dziecka, jakby coś jemu miało się stać" [K1]. W wypowiedziach rodziców obojga płci pojawiły się uwagi na temat gotowości bronienia dziecka za wszelką cenę: „tak podejrzewam, [...] że gdyby ktoś chciał dziecku coś zrobić, to mogłaby się bestia we mnie obudzić, że stanęłabym w obronie” [K9]; „Wydaje mi się, że się stałem bardziej waleczny o niektóre rzeczy to znaczy nie walczyłem nigdy chyba, nigdy nie walczyłem o siebie, tak jak w niektórych sytuacjach miałem poczucie tam jakieś walki czy przekonania, że walczyłbym o dziecko. [...] Tak jak rycząca lwica albo locha z małymi dziczkami” [M19]. 
Zarówno w wypowiedziach kobiet, jak i mężczyzn pojawiły się uwagi na temat zmiany podejścia do upływającego czasu, lepszego „zarządzania czasem” i organizacji dnia, odkąd są rodzicami: „,nauczyłam się, że ten czas tak szybko ucieka [...] że jakoś muszę lepiej wykorzystywać czas i znaleźć czas dla siebie, żeby móc poczytać książkę, coś tam sobie obejrzeć, czy się spotkać z koleżanką...” [K1]; „To jest trochę tak, im człowiek więcej w ciągu dnia robi tym więcej ma czasu. Dzień tak się więcej rozciąga" [M15]. Jeden z ojców zauważył, że przestał robić długoterminowe plany, starając przewidywać co się może wydarzyć i przygotowywać na każdą ewentualność, a zaczął „cieszyć konkretnym dniem” [M17].

Jeżeli chodzi o specyficzne doświadczenia zmian w samym sobie, obserwowane przez kobiety i mężczyzn zostających rodzicami, matki częściej niż ojcowie mówiły o zejściu na dalszy plan własnych potrzeb i celów po pojawieniu się dziecka. Jak zaznaczyła jedna z kobiet, nie sądziła, że będzie w stanie tak się poświęcić dzieciom, zrezygnować z własnych przyjemności: „Ja myślę, że byłam taka bardzo egoistycznie, egocentrycznie nastawiona generalnie $i$ tak hedonistycznie jako studentka jeszcze i w ogóle. Natomiast przez te pierwsze lata wychowywania dzieci zupełnie takie nastawienie na dzieci, poświęcenie rodzinie, to co się na pewno zmieniło" [K3]. Zdaniem jednej z matek, kobieta zdolna jest do tak wielu wyrzeczeń, w przeciwieństwie do mężczyzn, ze względu na instynkt macierzyński: „Po prostu wydaje mi się, że fakt urodzenia dziecka, że to jest takie, nie chcę powiedzieć, że to jest inicjacja, żeby nie wyszło jakoś śmiesznie, ale to jest, no po prostu kobieta staje się inną kobietą. To wszystko, ten ból, właśnie to poświęcenie dla tego dziecka, zmiana sposobu myślenia, że teraz to nie ja jestem najważniejsza, ale pojawia się właśnie dziecko, to uczucie, to jest wszystko jakby determinowane przez ten instynkt macierzyński, stąd ja nie oczekuję, że Tomek będzie tak myślał" [K1]. Dla innej respondentki to wyzbycie się egoizmu i traktowanie spraw dziecka jako najważniejszych nie było pozytywną zmianą. Miała ona poczucie, że zapomina o własnych potrzebach i zainteresowaniach: „[...] nie chciałabym, żeby tak było, chciałabym te dwie rzeczy pogodzić, ale nawet już jak idę do sklepu, to nie jest tak, że idę i szukam czegoś dla siebie, tylko nie, szukam czegoś dla dziecka i potem sobie tak uświadamiam, nie, no przecież ja przyszłam sobie coś kupić. Ale zawsze muszę sobie o tym przypominać, to nie jest takie naturalne" [K5]. Także kolejna wypowiedź wskazuje na pewien żal matki, mającej poczucie, że wraz z pojawieniem się dziecka, „znika” ona sama jako indywidualność, jej osobiste potrzeby przestają się liczyć: „[...] moim zdaniem z chwilą, kiedy pojawiło się już dziecko, to już nie ma tej pojedynczej jednostki, nie ma mnie, tak naprawdę. [...] Nie ma takiej Oli, która sobie, nie wiem, idzie i myśli o niebieskich migdałach. Czy jeszcze kiedyś będzie? Nie wiem. $\mathrm{Na}$ razie nie ma" [K19]. Zdaniem innych uczestniczek badania to, że stały się mniej skoncentrowane na sobie, uczyniło ich życie łatwiejszym, bo przestały przejmować się wieloma problemami, nieważnymi w sytuacji, gdy priorytetem jest 
dziecko [K20]; „[...] ja dosyć byłam zaangażowana właśnie w, powiedzmy, moje zawodowe sprawy itd., a teraz jestem przekonana, że może się tam w mojej firmie dziać nie wiadomo co, ja mam to wszystko głęboko w nosie. Najważniejsze, żeby Ania zdrowa, prawda? Takie trochę bardziej zdroworozsądkowe podejście, mniej emocjonalne, może właśnie tutaj się emocjonalnie realizuję, dlatego tam nie muszę. Tak, że akurat z tego jestem całkiem zadowolona" [K18]. O zyskaniu większego dystansu w podejściu do pracy zawodowej wspominała także kolejna respondentka, podkreślając, że teraz rodzina jest dla niej najważniejsza i chciałby mieć pracę, która nie będzie jej przeszkadzać w spełnianiu się w roli matki: „Natomiast jestem w stanie, i to też chyba pokazuje pewną zmianę, jaka we mnie się zrodziła, przez to, że właśnie mam dziecko i przez to, że chcę mieć następne dzieci, że jestem w stanie naprawdę zrezygnować z tych moich ambicji kosztem tego, żeby po prostu mieć taką pracę przy której nie będę się bała zajść w ciążę, nie będę się bała, nie wiem, pójść na zwolnienie, jak dziecko będzie chore, nie będę, mówię, nie będę niewolnicą tej pracy i będę mogła również zrealizować się w rodzinie" [K1].

Tym co zaskakiwało młode matki, było odkrywanie w sobie umiejętności niezbędnych do opieki nad noworodkiem. Kobiety zwracały uwagę, że wiele rzeczy wiedziały „same z siebie”, przyszły im one naturalnie, mimo że obawiały się, że sobie nie poradzą na przykład z właściwym trzymaniem dziecka, przewijaniem czy kąpaniem. Jedna z respondentek określiła to jako odkrycie w sobie ,instynktu macierzyńskiego”: „Ja w ogóle będąc w ciąży się bałam tego, że ja właśnie nie mam takiego instynktu macierzyńskiego. Ja na przykład jak widziałam gdzieś u znajomych małe dzieci, czy coś, to nie byłam taka, żeby wziąć na ręce, owszem, tak z daleka, no fajne, fajne, ale nigdy raczej o tym nie myślałam. [...] A tu się okazało, że jakoś wszystko naturalnie" [K7].

Jedna z kobiet zaobserwowała w sobie, jak to określiła, „zwierzęce zachowania”, syndrom „samicy broniącej własnego dziecka”. Wspominała o instynktownym reagowaniu na płacz dziecka. Zauważyła także, że stała się zaborcza i niechętnie „dzieliła się” dzieckiem z mężem: „te pierwsze tygodnie to były takie, że jak mąż brał go na ręce, to ja byłam bardzo, miałam taki samczy instynkt, że jak on może w ogóle, żeby on nie brał mojego dziecka" [K3]. Również inna matka obserwowała u siebie skłonność do zawłaszczania dziecka [K6]. Kobiety opowiadały także o ciągłym lęku i przesadnej trosce o potomstwo, przyznając że ich własne zachowanie je same przeraża i męczy: ,mąż szedł do pracy, ja zostawałam sama i właściwie byłam przez ileś godzin w jakimś tam napięciu, czy się nic nie wydarzy [...] i ten strach, ja na przykład sprawdzałam przez bardzo długi czas, czy oddycha, czy nie oddycha... [...] przez jakiś czas bałam się zostawać sama z dzieckiem, jak robiło się ciemno za oknem i miałam z tym problem, bardzo chciałam, żeby Krzysiek przyjeżdżał do domu, wtedy kiedy już jest zmrok, nie wiem, dlaczego tak się działo, nie wiem, zupełnie było to irracjonalne" [K6]; „ja się cały czas martwię i myślę, że tak już do końca życia człowiek się będzie 
martwił o swoje dziecko” [K18]; „Zwłaszcza, gdy jest jedno dziecko, pojawia się od czasu do czasu taki lęk, że coś się może stać, że zostanie się bez tego dziecka. Ja mam czasami takie napady. To naprawdę jest chyba najgorsze" [K20].

Jak wynika z doświadczeń kobiet, macierzyństwo wpływa na umiejętność nawiązywania i podtrzymywania relacji międzyludzkich, ze względu na wspominane wyzbycie się egoizmu oraz pełniejsze ich przeżywanie. Respondentki wspominały na przykład o dojrzałości emocjonalnej, większej wyrozumiałości oraz otwartości także w stosunku do obcych ludzi: „Ja w ogóle byłam taka raczej skryta i zamknięta w sobie i nie lubiłam tak nawiązywać kontaktów tak bezpośrednio [...] natomiast teraz właśnie odkąd mam dziecko, to ktoś do mnie podchodzi i mnie zagaduje, to ja też się bardziej na to otworzyłam i nawet teraz tak jak patrzę z perspektywy czasu na siebie, to mogę siebie ocenić, że kurczę, ale ja to byłam jakaś taka niemiła dla ludzi” [K7]. Jedna z matek zauważyła, że dziecko ją ,,wyciszyło", jest mniej skłonna do kłótni, mniej konfliktowa, mniej nerwowo reaguje: „Mnie się wydaje, że ja się bardzo uspokoiłam, jestem teraz taką bardziej spokojną osobą, mniej nerwową i choleryczną, od kiedy mam małą" [K15]. Dla jednej z kobiet doświadczenie macierzyństwa i miłość do dziecka oznaczało intensywniejsze odczuwanie miłości do innych osób: „Ja na przykład nie potrafiłam tak kochać jak teraz zanim zostałam matką. Czyli jak teraz mam takie doświadczenia, to, nie wiem, to uczucie, czy do męża, czy do swojej mamy jest znacznie większe niż wcześniej. Tak jakbym nauczyła się kochać” [K1]. Respondentka przyznała, że jako matka zaczęła bardziej szanować swoich rodziców, a także partnera - ojca dziecka.

Mężczyźni stosunkowo częściej obserwowali u siebie zmiany w sferze emocjonalnej, co może być spowodowane tym, że odkrywali w sobie cechy nie mieszczące się w stereotypowym wizerunku mężczyzny i ojca - chłodnego, zdystansowanego, surowego i oszczędnego w wyrażaniu uczuć. Mówili o bezwarunkowej miłości, jaką czują do dziecka i którą „,widać na zewnątrz” [M4], czy o nadopiekuńczości, której nie spodziewali się po sobie: „Ja w sobie odkryłem, niestety, cechy, które doprowadzały mnie do furii u mojej własnej mamy, tzn. totalną nadopiekuńczość. [...] Z reguły to właśnie kobiety mają jakieś takie tendencje do bycia tą «mamą kurą», tutaj trzeba powiedzieć, że ja jestem bardziej ostrożny [...] zdaję sobie sprawę z tej cechy i ona u mnie wylazła, mówiąc prosto, w momencie, kiedy się urodziła córeczka, wcześniej u siebie tego nie widziałem" [M13]. Badani deklarujący, że wcześniej nie lubili dzieci, okrywali w sobie „duże pokłady cierpliwości i czułości” [M5], byli zaskoczeni stosunkiem do własnego dziecka, chęcią i umiejętnością zajmowania się nim [M11]. Jeden z respondentów przyznał, że odkąd jest ojcem bardzo łatwo się wzrusza, chociaż wydawało mu się, że jest twardym i zahartowanym przez życie mężczyzną. - „Myślałem, że tylko mięczaki płaczą i ja się miałem za twardego, [...] a jednak zauważyłem, że ostatnie pół roku jest tak, że nie to że z byle powodu, ale daję upust i rzeczywiście popłyną mi łzy" [M8]. 
Ojcowie mówili o większym poczuciu odpowiedzialności w związku z zostaniem rodzicem. Przejawia się to w konieczności większej kontroli własnych zachowań, co wynika z przekonania, że rodzic musi być wzorem dla własnego dziecka i podlega społecznej kontroli, co dotyczy zarówno ojca, jak i matki. „Każdy czuje odpowiedzialność, [...] wie, że bierze na siebie nowe obowiązki, wie, że jest oceniany bądź co bądź przez otoczenie, przez rodzinę, przez samego siebie, bo człowiek też się z samym sobą rozlicza. [...] I o ile kiedyś nie trzeba było się nad tym zastanawiać, była jakaś tam swoboda działania, o tyle teraz, każdy z nas, ja, żona, angażujemy się i jesteśmy postrzegani też przez dziecko i zdajemy sobie sprawę, że stanowimy jakiś tam przykład. I chcielibyśmy, żeby ten przykład był jak najbardziej trafny” [M2]; „To są takie banały, jak na przykład nasze palenie papierosów. Albo używanie brzydkich słów. To jest odpowiedzialność. Trzeba się wstrzymywać, w pewien sposób kontrolować" [M1]. Jeden z respondentów przyznał, że „zaczął o sobie myśleć bardziej krytycznie, zaczęły mu doskwierać pewne cechy, nad którymi musi popracować" [M6]. Inny z ojców był z kolei pod wrażeniem radzenia sobie z tak wieloma nowymi zadaniami: „W związku z pojawieniem się dzieci przybyło masę obowiązków i nie sądziłem, że będę w stanie tak się poświęcać, żeby tym obowiązkom sprostać. No i się okazało, że trzeba po prostu" [M3].

Podsumowując, jak pokazuje zebrany materiał, rodzicielstwo zmienia zarówno kobiety, jak i mężczyzn. I matki, i ojcowie obserwowali zmiany w sobie, jakie pociągnęło za sobą wejście w rolę rodzica. Tym samym zakwestionowane zostało tradycyjne rozumienie ojcostwa jako nie mającego większego wpływu na życie mężczyzny. Mężczyźni zauważali w sobie cechy mieszczące się w stereotypie kobiecości, takie jak emocjonalność, czułość, cierpliwość czy nastawienie na innych, nie na siebie, co można traktować jako przejaw androgynizacji rodzicielstwa.

Uczestniczące $\mathrm{w}$ badaniu kobiety zauważały u siebie więcej różnych zmian w związku z zostaniem rodzicem, niż mężczyźni. Mogło to wynikać z ich większego zaangażowania w opiekę nad dzieckiem w pierwszym okresie jego życia i w związku z tym z koniecznością sprawdzenia się, czy po prostu możliwością poznania siebie w wielu nowych sytuacjach. Respondentki, opowiadając o obserwowanych w sobie zmianach wskazywały przede wszystkim na cechy odpowiadające tradycyjnemu wizerunkowi kobiecości i macierzyństwa, jak na przykład skłonność do poświęcenia się dziecku, czy umiejętność zajmowania się dzieckiem. Używały zresztą takich określeń jak „instynkt macierzyński”, świadczących o ich przekonaniu o naturalności tych cech, co także mieści się w tradycyjnym modelu płci.

$\mathrm{Z}$ drugiej jednak strony szeroka gama różnych doświadczeń kobiet, także negatywnych, w odniesieniu do obserwowanych w sobie zmian świadczy o odrzuceniu przez nie tradycyjnego modelu macierzyństwa, opartego m.in. na idealizacji roli matki jako wiążącej się jedynie z pozytywnymi odczuciami i przekonaniu o uniwersalnym doświadczeniu rodzicielstwa. 


\subsection{Konkluzje}

Przedstawione wyniki badania dotyczące odczuwanych przez kobiety i mężczyzn zmian w związku z wejściem w rolę rodzica pozwalają dostrzec w ich rodzicielstwie elementy zarówno nowoczesnego, jak i tradycyjnego modelu płci. Nie znalazło tu potwierdzenia tradycyjne założenie o mniejszym znaczeniu roli ojca w życiu mężczyzny niż roli matki w życiu kobiety. Ojcowie mieli podobne jak matki poczucie, że dziecko zupełnie zmienia ich życie, obserwowali w sobie zmiany, przede wszystkim w sferze emocjonalnej. Nie można zatem stwierdzić, że kobiety intensywniej czy bardziej odczuwają zostanie rodzicem niż mężczyźni. Przejawem nowoczesnego rodzicielstwa jest także „odczarowanie”, demitologizacja ról rodzicielskich przez badanych. W tradycyjnym modelu płci zaprzeczano negatywnym odczuciom i emocjom, jakie mogą towarzyszyć matkom i ojcom. Dotyczyło to przede wszystkim macierzyństwa, które idealizowano jako pozytywne doświadczenie kobiety, związane z odczuwaniem bezwarunkowej miłości, posiadaniem wiedzy i umiejętności niezbędnych do właściwej opieki nad dzieckiem, a więc bezproblemowym wypełnianiem roli rodzica. Uczestniczący w badaniu rodzice mówili także o ciemnych stronach rodzicielstwa, jak ciągłe zmęczenie, konieczność rezygnacji z własnych przyjemności, rozdrażnienie i kłótnie między partnerami, czy stres wynikający ze świadomości ogromnej odpowiedzialności za życie i wychowanie dziecka. Respondenci przyznawali się do uczuć nie mieszczących się w stereotypach dotyczących ich płci, co także odpowiada nowoczesnemu modelowi kobiecości i męskości, kwestionującemu polaryzację płci. Mężczyźni otwarcie mówili o emocjach, także tych stereotypowo „kobiecych", jak miłość, czułość, lęk. Kobiety z kolei obserwowały u siebie agresję w sytuacjach mogących nieść zagrożenie dla ich dzieci.

Stwierdzone różnice w doświadczeniach matek i ojców wynikają z faktu, że to kobiety na jakiś czas rezygnowały z aktywności zawodowej i całe dnie spędzały w domu z dzieckiem. Ta „totalność” ich rodzicielstwa, pełne zaangażowanie kobiet w macierzyństwo szczególnie w pierwszym okresie życia dziecka sprawiło, że matki częściej niż ojcowie miały poczucie, że rola rodzica je zmienia. Częściej także oceniały te zmiany jako nie do końca pozytywne. $Z$ ich doświadczeń wyłania się tradycyjny w dużej mierze obraz macierzyństwa, opartego na całkowitym poświęceniu kobiety, jej „,naturalnych” predyspozycjach do opieki nad dzieckiem, niemal zwierzęcej więzi z nim. Jednak na podstawie zebranego materiału nie można stwierdzić istnienia uniwersalnego doświadczenia macierzyństwa i ojcostwa. Różnice w „odbiorze” zmian związanych z zostaniem rodzicem pojawiały się nie tylko między kobietami i mężczyznami, ale także w grupie matek i w grupie ojców. Płeć nie wyznacza zatem jakichś typowych i specyficznych dla kobiet i mężczyzn doświadczeń rodzicielstwa. 


\section{Zakończenie}

Celem autorki niniejszej pracy była analiza wzorów macierzyństwa i ojcostwa realizowanych przez młode wykształcone Polki i Polaków, ich osobowościowej definicji roli matki i ojca: deklarowanych zachowań oraz towarzyszących im przekonań, interpretacji, wyjaśnień, uzasadnień. Płaszczyzną odniesienia były zaprezentowane w części teoretycznej „typy idealne” tradycyjnego i nowoczesnego ujęcia kobiecości i męskości oraz macierzyństwa i ojcostwa. Na ich podstawie stworzono listy wskaźników pozwalających na opisanie badanych wzorów rodzicielstwa w kategoriach: tradycyjne - nowoczesne.

Stawiając pytanie, czy realizowane przez młodych wykształconych Polaków wzory macierzyństwa i ojcostwa miały tradycyjny czy nowoczesny charakter, spodziewaliśmy się (bo pokazywały to wyniki dotychczasowych badań społecznych), że w społecznej rzeczywistości elementy obu modeli płci współwystępują obok siebie. W przekonaniach i zachowaniach jednostki są tradycyjne w jednym aspekcie, nowoczesne - w innym. Na przykład badani przedstawiając podział ról rodzicielskich w swojej rodzinie, odpowiadający tradycyjnemu podziałowi pracy ze względu na płeć (tradycja), uzasadniali go nie naturą i biologicznymi różnicami między kobietami i mężczyznami, lecz wskazywali go jako efekt uzgodnień i najlepsze rozwiązanie w ich przypadku, nie „w ogóle”. Może to być przejaw racjonalizacji własnego działania, ale też dowód na zmianę sposobu myślenia o kobiecości, męskości i relacji płci.

$\mathrm{Na}$ podstawie analizy zebranego materiału badawczego nie da się jednoznacznie potwierdzić ani odrzucić postawionych hipotez dotyczących sposobu definiowania i realizowania ról płciowych i rodzicielskich przez uczestników badania. Spodziewano się, że będą oni definiować kobiecość i męskość w nowoczesny sposób - odrzucać stereotypy płciowe i tradycyjny podział ról oraz kwestionować traktowanie macierzyństwa i ojcostwa jako koniecznego elementu roli płciowej (hipoteza 1). Wyniki pokazują, że wśród badanych znalazły się zarówno osoby skłonne do stereotypizacji ze względu na płeć, posługujące się schematem polaryzacji płci, jak i takie, które je kwestionowały. W wyjaśnianiu obserwowanych przez siebie różnic płciowych respondenci odwoływali się zarówno do natury - podkreślając ich niezmienność, jak i do kultury, ukazując ich względność. Różnili się także w kwestii przyznawania jednostkom prawa do decydowania o tym, czy chcą być rodzicami. Jedni wskazywali, że nie da się uciec od „naturalnego popędu do posiadania potomstwa”, inni uznawali, że wybrany przez nich sposób na życie, polegający na byciu matką/ojcem, nie jest jedynym właściwym, obowiązującym wszystkich wzorem.

Badani różnili się także w sposobie definiowania i realizowania macierzyństwa i ojcostwa. Chociaż potwierdzona została hipoteza o preferowaniu równego 
zaangażowania obojga rodziców (hipoteza 2), jednak partnerstwo to było przez objętych badaniem rodziców różnie rozumiane. Dla jednych oznaczało ono podobieństwo, czy wręcz wymienność ról matki i ojca opierających się na androgyniczności kobiety i mężczyzny, stąd mówiono raczej o rodzicielstwie niż o każdej z ról osobna. Dla innych natomiast partnerstwo było ,równością w różnicy”, a zatem opierało się na specyfice macierzyństwa i ojcostwa, odmienności ich cech, zadań, relacji z dzieckiem. Oba rodzaje podejścia były zbieżne w przyjmowaniu zaangażowania obojga rodziców w opiekę rodziców jako coś oczywistego.

Analizowane wzory macierzyństwa i ojcostwa realizowane przez młodych wykształconych Polaków są niespójne, zawieszone pomiędzy tradycją i nowoczesnością. Badani odrzucali tradycyjny model rodziny i tradycyjny podział ról, traktując je jako należące do przeszłości. Jednak proszeni o pierwsze skojarzenia z kobiecością czy męskością, macierzyństwem czy ojcostwem, odwoływali się do stereotypów. Część badanych deklarowała, że role matki i ojca są podobne i wymienne, twierdząc chwilę potem, że kobiety są od pielęgnacji dziecka i okazywania mu miłości, a mężczyźni od wprowadzania go w świat zainteresowań, nauki oraz dyscyplinowania. Pojawiały się jednak głosy, które odrzucały ten podział na kobiece - męskie, dając możliwość każdemu z rodziców wykonywania takich zadań i pełnienia takich funkcji w opiece i wychowaniu dziecka, w których czuje się on najlepiej, bez względu na to, co ,przynależy” mu ze względu na płeć. Przytoczmy tu jedną z wypowiedzi: „Wydaje się, że w ogóle chyba określenie rola matki, rola ojca jest takie trochę, znaczy nie do końca się sprawdza, bo to zależy, jaka matka, jaki ojciec, to wszystko zależy od ludzi. Jeden ojciec zapewni dziecku to, drugi coś zupełnie innego. To jest kwestia charakteru, predyspozycji do pewnych rzeczy, jakiegoś poziomu, nie wiem, właśnie otwartości i stosunku do świata, no to, to wszystko ma wpływ. Tak, że podejrzewam, że optymalne jest, jeżeli się z góry nie zakłada, że matka ma robić to, a ojciec ma robić to. Wszystko zależy od tego, jak to w danym związku wygląda. Każdy powinien dać to, w czym jakby czuje się dobrze i co mu sprawia największą przyjemność tak, że wtedy to daje najlepszy wynik" [M10].

Te dylematy badanych i pewne sprzeczności w postrzeganiu i definiowaniu roli kobiety i mężczyzny, matki i ojca są wynikiem wciąż zachodzących zmian w ramach kulturowych koncepcji kobiecości i męskości. Obrazują to relacje badanych dotyczące partnerstwa w rodzicielstwie. Młodzi wykształceni ludzie uczestniczący w badaniu z reguły dzielili się bądź wymieniali obowiązkami związanymi z opieką nad dzieckiem. Niektórzy przyznawali jednak, że nie zawsze się to udaje, bo nie pozwala na to charakter i czas pracy zawodowej jednego z partnerów. Barierą okazywał się też czasami brak przekonania co do powodzenia i możliwości realizacji partnerskiego rodzicielstwa części mężczyzn, a także części kobiet, przywiązanych do typowo „kobiecych” i „męskich”, „matczynych” i „ojcowskich" cech, zadań i ról. Można zatem powiedzieć, że młodzi wykształceni ludzie $\mathrm{w}$ większości starają się realizować zasadę równości w rodzicielstwie w swoich 
rodzinach. Nie są natomiast zgodni co do tego, czy społeczne role matki i ojca należy traktować jako równe, w sensie takie same i wymienne, czy też równe, ale inne, specyficzne, jedyne w swoim rodzaju.

W odniesieniu do trzeciego obszaru badawczego, dotyczącego macierzyństwa i ojcostwa jako osobistego doświadczenia zmian w życiu oraz w postrzeganiu samego siebie potwierdzono hipotezę mówiącą o tym, że pojawienie się dziecka w życiu uczestników badania pociąga za sobą doświadczenie szeroko rozumianej zmiany, dotyczące zarówno kobiet, jak i mężczyzn (hipoteza 3). Przejawem nowoczesnego modelu płci było tu traktowanie ról rodzicielskich jako odgrywających równie ważną rolę w życiu matki i ojca. Rodzice obu płci wyrażali przekonanie, że pojawienie się dziecka w ich życiu pociągnęło za sobą wiele różnych zmian. Doświadczenia matek i ojców związane z pojawieniem się dziecka były często bardzo zbliżone, nasuwały im się te same refleksje, dostrzegali podobne zmiany w swoim życiu i w sobie samych.

Na różnice w doświadczanych zmianach przez kobiety i mężczyzn wpływa przede wszystkim status zawodowy rodziców. Matki rezygnowały z pracy zawodowej na rzecz całkowitego często poświęcenia się dla dziecka, co pociągało za sobą zmiany w planie dnia, poczucie zdominowania ich życia przez obowiązki rodzicielskie oraz rutyny i monotonii dni spędzanych $z$ dzieckiem $w$ domu. Należy tu podkreślić, że różnice $\mathrm{w}$,odbiorze” zmian związanych z zostaniem rodzicem pojawiały się nie tylko między kobietami i mężczyznami, ale także w grupie matek i w grupie ojców. Płeć nie wyznacza zatem jakichś typowych i specyficznych, uniwersalnych dla kobiet i mężczyzn doświadczeń rodzicielstwa, pozwalając na indywidualne, jedyne w swoim rodzaju jego przeżywanie przez każdą jednostkę.

Podsumowując, analiza wzorów rodzicielstwa młodych wykształconych Polaków potwierdza zaobserwowane już w innych badaniach społecznych (patrz podroz. 4.3) istnienie obok siebie wzorów tradycyjnych i nowoczesnych. A zatem w zbiorowości tej znalazły się osoby, które powielają „odwieczny”, tradycyjny, utarty sposób definiowania i realizowania kobiecości, męskości, macierzyństwa i ojcostwa i w swoich codziennych działaniach go reprodukują, odtwarzają. Drugą grupę charakteryzuje krytyczne podejście do tych utrwalonych reguł i ich kwestionowanie, przedefiniowywanie, przejawiające się w nowoczesnym rodzicielstwie. Oczywiście, między tymi krańcami kontinuum znajdują się osoby, które są częściowo tradycyjne i częściowo nowoczesne, tj. akceptują tradycyjny model płci nie we wszystkich aspektach, dokonując modyfikacji tych jego elementów, których nie mogą czy chcą w swoim życiu realizować. To zróżnicowanie zachowań jednostek pokazuje, że podmiotowość społecznych aktorów może przybierać różne formy. Za Sharon Hays można odróżnić „,podmiotowość sprawczą, która reprodukuje struktury (i wyraża się w nawykowych działaniach) od podmiotowości sprawczej, która je przeksztatca (i wyraża się w działaniach innowacyjnych)" (Hays 1994: 63-64, za: Wnuk-Lipiński 2005: 93). 
Jak pokazały wyniki badania, młodzi wykształceni ludzie byli krytycznie nastawieni do wzorów rodzicielstwa realizowanych w ich rodzinach pochodzenia. Negowali „nieprofesjonalną” wiedzę swoich rodziców z zakresu pielęgnacji, opieki i wychowania dziecka, odwołując się do wiedzy eksperckiej. W swoich wypowiedziach powoływali się na różnego rodzaju publikacje, wyniki badań dotyczących macierzyństwa i ojcostwa. Taka ich postawa świadczy o gotowości do podważania utartych i, wydawałoby się, trwałych i niezmiennych poglądów i wzorów zachowań, o ich „odczarowaniu”. Tradycja przestaje być dla nich czymś, co się bezrefleksyjnie przyjmuje i czego się przestrzega tylko dlatego, że „zawsze tak było”. Co nie oznacza zawsze jej odrzucenia. Badani odtwarzający w swoich działaniach tradycyjny model rodzicielstwa traktowali go jako właściwy i pożądany w związku z tym, że odnajdywali się w nim. Gotowe kulturowe schematy, dostarczające wskazówek jak postępować, odpowiadały im i nie widzieli potrzeby ich zmiany.

Wzory ról rodzicielskich realizowane przez młodych wykształconych Polaków okazały się ciekawym materiałem do analizy strukturacji społecznych praktyk, zjawiska dualizmu struktury. Na ich przykładzie można zauważyć, jak jednostki działają pod wpływem społecznych reguł, które dostarczają im scenariuszy działania, uzasadnień, schematów interpretacyjnych. W wypowiedziach badani odwoływali się na przykład do stereotypów płci, czy „naturalnych” różnic płci, za pomocą których wyjaśniali postępowanie swoje i partnera jako rodziców, jako kobiet/mężczyzn. Dostrzec można jednak także odwrotny kierunek wpływu społecznych aktorów na strukturę: młodzi wykształceni Polacy, pełniąc rodzicielskie role, opierali się na własnych koncepcjach macierzyństwa i ojcostwa, odpowiadających ich predyspozycjom, osobowym cechom, wyznawanym wartościom, doświadczeniom, uzgadnianych z drugim rodzicem. Swoimi działaniami reprodukowali i stwarzali społeczne reguły - kulturowe modele płci, będąc niekiedy bardzo zachowawczy i konserwatywni (realizowanie tradycyjnych wzorów macierzyństwa i ojcostwa), a niekiedy innowacyjni i rewolucyjni w swoim rozumieniu i realizowaniu ról rodzicielskich (na przykład skłanianie się ku androgynizacji rodzicielstwa). Jeszcze raz należy tu podkreślić, że nawet bardziej zachowawcze jednostki, odtwarzające w swoich działaniach tradycyjny model płci, nie pozostają biernymi wykonawcami społecznych reguł. Zgodnie z teorią strukturacji każde działanie przyczyniające się do reprodukowania struktury jest zarazem twórczym działaniem, wytwarzającym strukturę. „Tak samo, jak znaczenie słów zmienia się w czasie ich używania i z powodu używania" (Giddens 2001a: 182), tak powielane wzory zachowań nigdy nie są czystą kopią społecznych konwencji, zostają bowiem przez jednostki zinterpretowane na swój własny sposób, dostosowane do własnych preferencji, wartości, potrzeb i w rezultacie mniej lub bardziej przekształcane, zmieniane. 


\section{Bibliografia}

Adamiak Elżbieta, 1999, Milcząca obecność: o roli kobiety w Kościele, Biblioteka „Więzi”, Warszawa.

Arcimowicz Krzysztof, 1998, Współcześni mężczyźni. Przegląd badań, „Problemy Rodziny”, nr 2. Arcimowicz Krzysztof, 2003, Obraz mężczyzny w polskich mediach. Prawda - fatsz - stereotyp, Gdańskie Wydawnictwo Psychologiczne, Gdańsk.

Arcimowicz Krzysztof, 2007, Wizerunek ojca w polskich mediach na przełomie XX i XXI wieku, (w:) M. Fuszara (red.), Nowi mężczyźni? Zmieniające się modele męskości we współczesnej Polsce, Wydawnictwo Trio, Warszawa.

Arcimowicz Krzysztof, 2008a, Przemiany męskości w kulturze współczesnej, (w:) M. Fuszara (red.), Nowi mężczyźni? Zmieniające się modele męskości we wspótczesnej Polsce, Wydawnictwo Trio, Warszawa.

Arcimowicz Krzysztof, 2008b, Transgenderowe wzory zachowań mężczyzn (na przykładzie berdyszów, fa'afafine i hidżra), (w:) A. Radomski, B. Truchlińska (red.), Męskość w kulturze wspótczesnej, Wydawnictwo Uniwersytetu Marii Curie-Skłodowskiej, Lublin.

Arcimowicz Krzysztof, 2010, Obraz mężczyzny w polskich przekazach medialnych na przełomie stuleci, (w:) M. Dąbrowska, A. Radomski (red.), Męskość jako kategoria kulturowa. Praktyki męskości, Wydawnictwo Portalu Wiedza i Edukacja, Lublin.

Arcimowicz Krzysztof, 2011, Nowe wizerunki mężczyzn w polskich przekazach telewizyjnych, (w:) K. Wojnicka, E. Ciaputa (red.), Karuzela z mężczyznami. Problematyka męskości w polskich badaniach społecznych, Oficyna Wydawnicza Impuls, Kraków.

Aronson Elliot, Wilson Timothy D., Akert Robin M., 1997, Psychologia społeczna. Serce i umyst, Wydawnictwo Zysk i S-ka, Poznań.

Augustyn Józef SI, 1998a, Dojrzewanie do ojcostwa, (w:) J. Augustyn SI (red.), Ojcostwo, Wydawnictwo WAM, Kraków.

Augustyn Józef SI, 1998b, Co matka i ojciec daja dziecku?, (w:) J. Augustyn SI (red.), Macierzyństwo, Wydawnictwo WAM, Kraków.

Augustyn Józef SI (red.), 1998, Ojcostwo, Wydawnictwo WAM, Kraków.

Augustyn Józef SI (red.), 1998, Macierzyństwo, Wydawnictwo WAM, Kraków.

Babbie Earl, 2008, Podstawy badań społecznych, Państwowe Wydawnictwo Naukowe, Warszawa.

Badinter Elisabeth, 1993, XY tożsamość mężczyzny, Wydawnictwo W.A.B., Warszawa.

Badinter Elisabeth, 1998, Historia miłości macierzyńskiej, Oficyna Wydawnicza Wolumen, Warszawa.

Badinter Elisabeth, 2013, Konflikt: kobieta i matka, Państwowe Wydawnictwo Naukowe, Warszawa.

Balcerzak-Paradowska Bożena, 2004a, Rodzina i polityka rodzinna na przełomie wieków, Instytut Pracy i Spraw Socjalnych, Warszawa.

Balcerzak-Paradowska Bożena, 2004b, Rola państwa w ksztaltowaniu polityki rodzinnej w Polsce w okresie transformacji, (w:) D. Graniewska (red.), Sytuacja rodzin i polityka rodzinna w Polsce. Uwarunkowania demograficzne i spoteczne, Instytut Pracy i Spraw Socjalnych, Warszawa.

Balcerzak-Paradowska Bożena, 2005, Ochrona pracy kobiet $w$ ciąży $i$ wychowujacych małe dzieci z perspektywy pracodawców w Polsce, (w:) I. Wóycicka (red.), Szanse na wzrost dzietności - jaka polityka rodzinna, Polskie Forum Strategii Lizbońskiej, Gdańsk.

Balcerzak-Paradowska Bożena, 2008, Rozwiązania w zakresie ułatwienia godzenia życia zawodowego z rodzinnym jako element polityki rodzinnej, (w:) C. Sadowska-Snarska (red.), Kierunki działań w Polsce na rzecz równowagi praca-życie - rodzina, Wydawnictwo Wyższej Szkoły Ekonomicznej w Białymstoku, Białystok. 
Barabasz Anna, 2007, Mężczyzna metroseksualny i mężczyzna überseksualny - czyli jaki? Internetowe wzorce męskości - próba analizy socjologicznej, (w:) K. Piątek (red.), Męskość (nie) męska. Współczesny mężczyzna w zmieniającej się rzeczywistości społecznej, Wydawnictwo Akademii Techniczno-Humanistycznej w Bielsku-Białej, Bielsko-Biała.

Baranowska Anna, 2007, Poglady i preferencje dotyczace ekonomicznych modeli rodziny, (w:) I.E. Kotowska, U. Sztanderska, I. Wóycicka (red.), Aktywność zawodowa i edukacyjna a obowiazki rodzinne $w$ Polsce $w$ świetle badań empirycznych, Wydawnictwo Naukowe Scholar, Warszawa.

Bardwick Judith M., Douvan Elisabeth, 1982, Ambiwalencja: socjalizowanie kobiet, (w:) T. Hołówka (red.), Nikt nie rodzi się kobieta, Czytelnik, Warszawa.

Bartkowski Jerzy, 2009, Wartości materialistyczne i postmaterialistyczne w Polsce w ujęciu porównawczym, (w:) M. Zahorska, E. Nasalska (red.), Wartości, polityka, społeczeństwo, Wydawnictwo Naukowe Scholar, Warszawa.

Bartosz Bogna, 2002, Doświadczanie macierzyństwa: analiza narracji autobiograficznych, Wydawnictwo Uniwersytetu Wrocławskiego, Wrocław.

Bauman Zygmunt, 1999a, Po co komu teoria zmiany?, (w:) J. Kurczewska (red.), Zmiana spoteczna. Teorie i doświadczenia polskie, Wydawnictwo Instytutu Filozofii i Socjologii PAN, Warszawa.

Bauman Zygmunt, 1999b, Florian Znaniecki, nasz wspótczesny, (w:) E. Hałas (red.), Teoria socjologiczna Floriana Znanieckiego a wyzwania XXI wieku, Towarzystwo Naukowe Katolickiego Uniwersytetu Lubelskiego, Lublin.

Bator Joanna, 1999, Wizerunek kobiety w polskiej debacie politycznej, Instytut Spraw Publicznych, Warszawa.

Beall A.E., 2002, Społeczno-konstruktywistyczne podejście do rodzaju, (w:) B. Wojciszke (red.), Kobiety i mężczyźni: odmienne spojrzenia na różnice, Gdańskie Wydawnictwo Psychologiczne, Gdańsk.

Beck Ulrich, 2002, Spoleczeństwo ryzyka, Wydawnictwo Naukowe Scholar, Warszawa.

Behnke Cornelia, Loos Peter, Meuser Michael, 2004, Habitualna męskość - o kolektywnych orientacjach gender, (w:) S. Krzychała (red.), Społeczne przestrzenie doświadczenia. Metoda interpretacji dokumentarnej, Wydawnictwo Naukowe Dolnośląskiej Szkoły Wyższej Edukacji TWP, Wrocław.

Bem Sandra L., 2000, Męskość, kobiecość. O różnicach wynikających z płci, Gdańskie Wydawnictwo Psychologiczne, Gdańsk.

Benedict Ruth, 1999, Wzory kultury, Warszawskie Wydawnictwo Literackie Muza, Warszawa.

Berger Peter L., 2004, Zaproszenie do socjologii, Państwowe Wydawnictwo Naukowe, Warszawa.

Białyszewski Henryk, 1967, Rola społeczna jako kategoria struktury, „Studia Socjologiczne”, nr 1.

Biddle Bruce J., 1992, Wspótczesne tendencje w teorii roli, (w:) J. Szmatka (red.), Elementy mikrosocjologii, Wydawnictwo Uniwersytetu Jagiellońskiego, Kraków.

Biddulph Steve, 2004, Męskość, Dom Wydawniczy Rebis, Poznań.

Bielajew E.W., Szalin D.N., 1978, Pojęcie „rola społeczna” w socjologii, (w:) J. Szmatka (red.), Elementy mikrosocjologii, Wydawnictwo Uniwersytetu Jagiellońskiego, Kraków.

Bieńkowska-Ptasznik Małgorzata, 2007, Transseksualizm - wyjście poza normę, „uniGENDER” $\mathrm{nr}$ 1, http://www.unigender.org/?page=biezacy\&issue $=02 \&$ article $=03$ (dostęp 1 sierpnia 2010.).

Bieńkowska-Ptasznik Małgorzata, 2011, Dylematy badacza - wybrane niuanse z badań nad transseksualizmem, (w:) K. Slany, B. Kowalska, M. Ślusarczyk (red.), Kalejdoskop genderowy. $W$ drodze do poznania płci społeczno-kulturowej w Polsce, Wydawnictwo Uniwersytetu Jagiellońskiego, Kraków.

Bobako Monika, 2010, Demokracja wobec różnicy. Multikulturalizm i feminizm w perspektywie polityki uznania, Wydawnictwo Poznańskie, Poznań.

Bogucka Maria, 2005, Gorsza pteć. Kobieta w dziejach Europy od antyku po wiek XXI, Wydawnictwo Trio, Warszawa. 
Bohnsack Ralf, 2004, Dyskusja grupowa - teoria i praktyka rekonstrukcji kolektywnych wzorów orientacji, (w:) S. Krzychała (red.), Społeczne przestrzenie doświadczenia. Metoda interpretacji dokumentarnej, Wydawnictwo Naukowe Dolnośląskiej Szkoły Wyższej Edukacji TWP, Wrocław.

Boski Paweł, 1999, Męskość - kobiecość jako wymiar kultury. Przeglad koncepcji i badań, (w:) J. Miluska, P. Boski (red.), Męskość - kobiecość w perspektywie indywidualnej i kulturowej, Wydawnictwo Instytutu Psychologii PAN, Warszawa.

Boski Paweł, 2009, Kulturowe ramy zachowań społecznych, Państwowe Wydawnictwo Naukowe, Warszawa.

Bourdieu Pierre, 2004, Męska dominacja, Oficyna Naukowa, Warszawa.

Bradley Harriet, 2008, Płeć, Wydawnictwo Sic!, Warszawa.

Brannon Linda, 2002, Psychologia rodzaju, Gdańskie Wydawnictwo Psychologiczne, Gdańsk

Brod Harry, 1987, A Case for Men's Studies, (w:) M.S. Kimmel (ed.), Changing men: new directions in research on men and masculinity, Sage Publications, Newbury Park.

Buczkowski Andrzej, 1997, Dwa różne światy, czyli jak socjalizuje się dziewczynkę i chtopca, (w:) J. Brach-Czaina (red.), Od kobiety do mężczyzny i z powrotem. Rozważania o ptci w kulturze, TransHumana, Białystok.

Budrowska Bogusława, 1997, Macierzyństwo: instytucja totalna?, (w:) J. Brach-Czaina (red.), Od kobiety do mężczyzny i z powrotem. Rozważania o płci w kulturze, TransHumana, Białystok.

Budrowska Bogusława, 2000, Macierzyństwo jako punkt zwrotny w życiu kobiety, Wydawnictwo Funna, Wrocław.

Budrowska Bogusława, 2001, Regulamin i improwizacje, czyli o kulturowym skrypcie bycia matka, „Kultura i Społeczeństwo”, nr 2.

Budrowska Bogusława, 2003, Znikoma reprezentacja kobiet w elitach - próby wyjaśnień, (w:) A. Titkow (red.), Szklany sufit. Bariery i ograniczenia karier kobiet. Monografia zjawiska, Instytut Spraw Publicznych, Warszawa.

Budrowska Bogusława, 2008, Tacierzyństwo, czyli nowy wzór ojcostwa, „Kultura i Społeczeństwo”, nr 3.

Bullinger Hermann, 1997, Mężczyzna czy ojciec?, Niezależna Oficyna Wydawnicza, Warszawa.

Butler Judith, 2008, Uwiktani w płeć, Wydawnictwo Krytyki Politycznej, Warszawa.

CBOS, 2006, Opinie o pracy zawodowej kobiet, Komunikat z badań, BS/184/2006, Warszawa

CBOS, 2009a, Opinie o funkcjonowaniu demokracji w Polsce, Komunikat z badań, BS/20/2009, Warszawa.

CBOS, 2009b, Wiara i religijność Polaków dwadzieścia lat po rozpoczęciu przemian ustrojowych, Komunikat z badań, BS/34/2009, Warszawa.

CBOS, 2010, Co jest ważne, co można, a czego nie wolno - normy i wartości w życiu Polaków, Komunikat z badań, BS/99/2010, Warszawa.

CBOS, 2013a, Mirosława Grabowska (red.), Kobieta w rodzinie, w pracy, w przestrzeni publicznej, „Opinie i Diagnozy”, nr 25, Warszawa.

CBOS, 2013b, Polacy o demokracji, Komunikat z badań, BS/125/2013, Warszawa.

CBOS, 2013c, Wartości i normy, Komunikat z badań, BS/111/2013, Warszawa.

Chełstowska Agata, Zarzyńska Agnieszka, 2014, Urlopy dla ojców w kontekście różnych modeli polityki rodzinnej w Europie, Instytut Spraw Publicznych, Warszawa.

Chłoń-Domińczak Agnieszka, 2010, Dyrektywy równościowe jako instrument przeciwdziałania dyskryminacji w rodzinie ze względu na wiek, płeć i status ekonomiczny, (w:) E. Leś, S. Bernini (red.), Przemiany rodziny w Polsce $i$ we Włoszech i ich implikacje dla polityki rodzinnej, Wydawnictwo Uniwersytetu Warszawskiego, Warszawa.

Chmura-Rutkowska Iwona, Ostrouch Joanna, 2007, Mężczyźni na przełęczy życia. Studium socjopedagogiczne, Oficyna Wydawnicza „Impuls”, Kraków. 
Ciaputa Ewelina, 2011, Jak płeć stawała się rodzajem, (w:) K. Slany, B. Kowalska, M. Ślusarczyk (red.), Kalejdoskop genderowy. $W$ drodze do poznania ptci społeczno-kulturowej w Polsce, Wydawnictwo Uniwersytetu Jagiellońskiego, Kraków.

Cicha Marlena, 2006, Kobieta i kobiecość w opiniach młodych dorostych mężczyzn, (w:) J. Ostrouch (red.), Przywiązanie i przekraczanie. Płeć w studiach empirycznych, Uniwersytet Warmińsko-Mazurski, Olsztyn.

Ciechomska Maria, 1996, Od matriarchatu do feminizmu, „Brama” - Książnica Włóczęgów i Uczonych, Poznań.

Connell Raewyn, 2013, Socjologia ptci. Pteć w ujęciu globalnym, Państwowe Wydawnictwo Naukowe, Warszawa.

Dahrendorf Ralf, 2005a, Homo sociologicus. O historii, znaczeniu i granicach kategorii roli spotecznej, (w:) P. Sztompka, M. Kucia (red.), Socjologia. Lektury, Wydawnictwo Znak, Kraków.

Dahrendorf Ralf, 2005b, Grupy odniesienia i przypisywanie ról, (w:) Socjologia. Lektury, (red.) P. Sztompka, M. Kucia, Wydawnictwo Znak, Kraków.

Daniłowicz Paweł, Lisek-Michalska Jolanta, 2004, Fokus - zogniskowany wywiad grupowy. Zarys metody, (w:) J. Lisek-Michalska, P. Daniłowicz (red.), Zogniskowany wywiad grupowy. Studia nad metoda, Wydawnictwo Uniwersytetu Łódzkiego, Łódź.

Dąbrowska Grażyna, 1996, Kobieta w sferze życia rodzinnego, (w:) J. Sikorska (red.), Kobiety i ich mężowie. Studium porównawcze, Wydawnictwo Instytutu Filozofii i Socjologii PAN, Warszawa.

Dąbrowska Zofia, 2004, Różne oblicza ojcostwa, „Małżeństwo i Rodzina”, nr 1.

Dąbrowska Zofia, 2007, Wspótczesne ojcostwo w swym zróżnicowaniu i rozwoju (typologia własna), (w:) H. Marzec, M. Pindera (red.), Problemy rodziny na początku trzeciego tysiaclecia, t. I, Naukowe Wydawnictwo Piotrkowskie, Piotrków Trybunalski.

Dąbrowska-Wnuk Marianna, 2007, Na drodze ku nowemu ojcostwu, (w:) E. Mandal (red.), W kręgu gender, Wydawnictwo Uniwersytetu Śląskiego, Katowice.

Deaux Kay, Kite Mary, 2002, Stereotypy ptci, (w:) B. Wojciszke (red.), Kobiety i mężczyźni: odmienne spojrzenia na różnice, Gdańskie Wydawnictwo Psychologiczne, Gdańsk.

Delumeau Jean, Roche Daniel (red.), 1995, Historia ojców i ojcostwa, Oficyna Wydawnicza Volumen, Warszawa.

Dench Geoff, 1998, Pocalunek królewny. Problem mężczyzn, Wydawnictwo Instytutu Filozofii i Socjologii PAN, Warszawa.

Domański Henryk, 1992, Zadowolony niewolnik? Studium o nierównościach między mężczyznami $i$ kobietami w Polsce, Wydawnictwo Instytutu Filozofii i Socjologii PAN, Warszawa.

Domański Henryk, 1995, Równouprawnienie. Stereotyp tradycyjnego podziału ról, (w:) A. Titkow, H. Domański (red.), Co to znaczy być kobieta w Polsce?, Wydawnictwo Instytutu Filozofii i Socjologii PAN, Warszawa.

Domański Henryk, 2002, Co wiemy na temat nierówności płci?, „Res Publica Nowa”, nr 6.

Duch-Krzystoszek Danuta, 1996, Relacje między praca domowa i zawodowa, (w:) J. Sikorska (red.), Kobiety i ich mężowie. Studium porównawcze, Wydawnictwo Instytutu Filozofii i Socjologii PAN, Warszawa.

Duch-Krzystoszek Danuta, 2007, Kto rządzi w rodzinie, Wydawnictwo Instytutu Filozofii i Socjologii PAN, Warszawa.

Dudek Zenon W., 2007, Płeć psychologiczna, wzorce kultury i duchowość, „ALBO ALBO. Problemy Psychologii i Kultury”, nr 2.

Dukaczewska-Nałęcz Aleksandra, 1999, Zogniskowane wywiady grupowe - jakościowa technika badawcza, (w:) H. Romański, K. Lutyńska, A.W. Rostocki (red.), Spojrzenie na metodę. Studia z metodologii badań socjologicznych, Wydawnictwo Instytutu Filozofii i Socjologii PAN, Warszawa.

Dybel Paweł, 2006, Zagadka „drugiej ptci”. Spory wokót różnicy seksualnej w psychoanalizie $i$ w feminizmie, Wydawnictwo Universitas, Kraków. 
Dziekanowska Małgorzata, 2008, Męska pteć kulturowa w perspektywie socjologicznej, (w:) A. Radomski, B. Truchlińska (red.), Męskość w kulturze współczesnej, Wydawnictwo Uniwersytetu Marii Curie-Skłodowskiej, Lublin.

Dzierzgowska Anna, 2009, Edukacja i płeć, (w:) Raport. Kobiety dla Polski Polska dla kobiet. 20 lat transformacji 1989-2009, Fundacja Feminoteka, Warszawa, www.kongreskobiet.pl

Dzwonkowska-Godula Krystyna, 2011, Publiczny dyskurs o współczesnym ojcostwie w Polsce, (w:) K. Wojnicka, E. Ciaputa (red.), Karuzela z mężczyznami. Problematyka męskości w polskich badaniach społecznych, Oficyna Wydawnicza Impuls, Kraków.

Dzwonkowska-Godula Krystyna, 2012, Demitologizacja macierzyństwa? Rola matki w percepcji młodych wyksztatconych rodziców, (w:) J. Deręgowska, M. Majorczyk (red.), Konteksty współczesnego macierzyństwa. Perspektywa młodych naukowców, Wyższa Szkoła Nauk Humanistycznych i Dziennikarstwa, Poznań.

Ehrlich Stanisław, 1994, Dynamika norm. Podstawowe zagadnienia wiążących wzorów zachowania, Wydawnictwo Szkolne i Pedagogiczne, Warszawa.

Eichelberger Wojciech, 1997, Kobieta bez winy i wstydu, Wydawnictwo Do, Warszawa

Firlit-Fesnak Grażyna, 2005, Wspólnotowa polityka na rzecz równości kobiet i mężczyzn. Ewolucja celów i instrumentów działania, Instytut Polityki Społecznej, Uniwersytet Warszawski, Warszawa.

Firlit-Fesnak Grażyna, 2007, Rodziny polskie i polityka rodzinna: stan i kierunki przemian, (w:) G. Firlit-Fesnak, M. Szylko-Skoczny (red.), Polityka społeczna. Podręcznik akademicki, Państwowe Wydawnictwo Naukowe, Warszawa.

Flood Michael, 2003, Fatherhood and fatherlessness, „Discussion Paper”, November, no 59, The Australia Institute, Canberra.

Flood Michael, 2008, Przegięci heteroseksualni: różnorodność i przemiany wśród heteroseksualnych mężczyzn, (w:) E. Oleksy (red.), Tożsamość i obywatelstwo w spoleczeństwie wielokulturowym, Państwowe Wydawnictwo Naukowe, Warszawa.

Friedan Betty, 2013, Mistyka kobiecości, Wydawnictwo Czarna Owca, Warszawa.

Frąckowiak-Sochańska Monika, 2009, Preferencje ładów normatywnych w postawach kobiet wobec wartości w Polsce na przełomie XX i XXI wieku, Wydawnictwo Poznańskie, Poznań.

Fromm Erich 1971, O sztuce miłości, Państwowy Instytut Wydawniczy, Warszawa.

Fromm Erich, 1999, Miłość, pleć i matriarchat, Dom Wydawniczy REBIS, Poznań.

Funk Rainer, 1999, Słowo od wydawcy niemieckiego, (w:) Miłość, płeć i matriarchat, Dom Wydawniczy REBIS, Poznan.

Fuszara Małgorzata (red.), 2002, Kobiety na przełomie wieków: Nowy kontrakt ptci?, Instytut Spraw Publicznych, Warszawa.

Fuszara Małgorzata, 2008, Ojcostwo w opinii mężczyzn - ojców małych dzieci, (w:) M. Fuszara (red.), Nowi mężczyźni? Zmieniajace się modele męskości we współczesnej Polsce, Wydawnictwo Trio, Warszawa.

Gajewska Agnieszka, 2008, Hasło: feminizm, Wydawnictwo Poznańskie, Poznań.

Garncarek Emilia, 2010, Kobiece ciało jako przedmiot kontroli społecznej, „Przegląd Socjologiczny", t. LIX, nr 3.

Gawkowska Aneta, 2008, Nowy feminizm - poszukiwanie esencji kobiecości, „Societas/Communitas", $\mathrm{nr} 2(6)$.

Gawlicz Katarzyna, 2009, Negocjowanie znaczenia kategorii płci. Pomiędzy różnicowaniem płciowym a przekraczaniem granic, (w:) L. Kopciewicz, E. Zierkiewicz (red.), Koniec mitu niewinności? Płeć i seksualność w socjalizacji i edukacji, Wydawnictwo Psychologii i Kultury ENETEIA, Warszawa.

Gawlina Zofia, 2003, Macierzyństwo jako wartość w kontekście przemian spolecznych, (w:) Z. Tyszka (red.), Blaski i cienie życia rodzinnego, ,Roczniki Socjologii Rodziny”, nr XV. 
Gębala Przemysław, 2007, Schematy i transgresje ptci, „ALBO ALBO. Problemy Psychologii i Kultury", nr 2.

Gębka Mikołaj, 2006, Trzy pytania o kryzys ojcostwa, (w:) A. Michalska (red.), Obrazy życia rodzinnego z perspektywy interdyscyplinarnej, ,Roczniki Socjologii Rodziny”, nr XVII.

Gębka Mikołaj, 2007, Ojciec jako rodziciel, (w:) A. Kotlarska-Michalska (red.), Wizerunki ról rodzinnych, „Roczniki Socjologii Rodziny”, nr XVIII.

Gębuś Dorota, 2006, Rodzina. Tak, ale jaka?, Wydawnictwo Akademickie Żak, Warszawa.

Gergen J. Kenneth, 2009, Nasycone Ja. Dylematy tożsamości w życiu współczesnym, Państwowe Wydawnictwo Naukowe, Warszawa.

Giddens Anthony, 1979, Central Problems In Social Theory. Action, structure and contradiction in social analysis, University of California Press, Berkeley.

Giddens Anthony, 1998, Socjologia. Zwięzłe lecz krytyczne wprowadzenie, Zysk i S-ka, Poznań.

Giddens Anthony, 1999, Trzecia droga. Odnowa socjaldemokracji, Książka i Wiedza, Warszawa.

Giddens Anthony, 2001a, Nowe zasady metody socjologicznej. Pozytywna krytyka socjologii interpretatywnych, Zakład Wydawniczy Nomos, Warszawa.

Giddens Anthony, 2001b, Nowoczesność i tożsamość. „Ja” $i$ spoleczeństwo w epoce późnej nowoczesności, Państwowe Wydawnictwo Naukowe, Warszawa.

Giddens Anthony, 2003, Stanowienie spoleczeństwa. Zarys teorii strukturacji, Zysk i S-ka, Poznań.

Giddens Anthony, 2004, Socjologia, Państwowe Wydawnictwo Naukowe, Warszawa.

Giddens Anthony, 2006, Przemiany intymności. Seksualność, miłość i erotyzm we współczesnych społeczeństwach, Państwowe Wydawnictwo Naukowe, Warszawa.

Giddens Anthony, 2008, Konsekwencje nowoczesności, Wydawnictwo Uniwersytetu Jagiellońskiego, Kraków.

Giddens Anthony, 2009, Życie w społeczeństwie posttradycyjnym, (w:) U. Beck, A. Giddens, S. Lash, Modernizacja refleksyjna. Polityka, tradycja i estetyka w porzadku społecznym nowoczesności, Państwowe Wydawnictwo Naukowe, Warszawa.

Giza-Poleszczuk Anna, 2002a, Związi partnerskie, matżeństwo i dzieci-kulturowe zróżnicowanie postaw, (w:) A. Jasińska-Kania, M. Marody (red.), Polacy wśród Europejczyków. Wartości spoteczeństwa polskiego na tle innych krajów europejskich, Wydawnictwo Naukowe Scholar, Warszawa.

Giza-Poleszczuk Anna, 2002b, Rodzina i system spoteczny, (w:) M. Marody (red.), Wymiary życia społecznego. Polska na przełomie XX i XXI wieku, Wydawnictwo Naukowe Scholar, Warszawa.

Giza-Poleszczuk Anna, 2004, W poszukiwaniu , nowego przymierza” wzajemne oczekiwania mężczyzn i kobiet w Polsce, (w:) M. Marody (red.), Zmiana czy stagnacja? Społeczeństwo polskie po czternastu latach transformacji, Wydawnictwo Naukowe Scholar, Warszawa.

Glennon Lynda M., 1982, Kobiety i dualizm, (w:) T. Hołówka, (red.) Nikt nie rodzi się kobieta, Czytelnik, Warszawa.

Glover David, Kaplan Cora, 2007, Pteć kulturowa a nauka o płci, (w:) M. Dąbrowski, R. Pruszczyński (red.), Lektury inności. Antologia, Dom Wydawniczy Elipsa, Warszawa

Głażewska Ewa, 2004, Asymetria w kulturowej ewaluacji ptci - podstawowe dychotomie: natural kultura, sfera prywatna/sfera publiczna, reprodukcja/produkcja, (w:) A. Kuczyńska, E.K. Dzikowska (red.), Zrozumieć płeć. Studia interdyscyplinarne II, Wydawnictwo Uniwersytetu Wrocławskiego, Wrocław.

Głażewska Ewa, 2005, Płeć i antropologia. Kulturowa koncepcja płci w ujęciu Margaret Mead, Centrum Edukacji Europejskiej, Toruń.

Goffman Erving, 1981, Człowiek w teatrze życia codziennego, Państwowy Instytut Wydawniczy, Warszawa.

Gontarczyk Ewa, 1995, Kobiecość i męskość jako kategorie społeczno-kulturowe w studiach feministycznych, Wydawnictwo Eruditus, Poznań. 
Grey John, 1995, Mężczyźni są z Marsa a kobiety z Wenus, Zysk i S-ka, Poznań.

Grochalska Monika, 2006, Życie rodzinne pracujacych zawodowo kobiet i ich relacje z bezrobotnymi mężami, (w:) J. Ostrouch (red.), Przywiazanie i przekraczanie. Pteć w studiach empirycznych, Wydawnictwo Uniwersytetu Warmińsko-Mazurskiego, Olsztyn.

Groth Jarosław, 2000, Nieobecność ojca, (w:) S. Jabłoński (red.), Ojciec..., Wydawnictwo Fundacji Humaniora, Poznań.

Growiec Katarzyna, 2008, Jak wspierać rodzicielstwo. Nowoczesna polityka prenatalna a rozwój kapitalu intelektualnego Polski, Instytut Spraw Publicznych, „Analizy i Opinie”, nr 88.

Grygiel Aneta, 2006, Młodzi mężczyźni wobec ojcostwa, (w:) J. Ostrouch (red.), Przywiązanie i przekraczanie. Pteć w studiach empirycznych, Wydawnictwo Uniwersytetu Warmińsko-Mazurskiego, Olsztyn.

Grygiel Aneta, 2010, Nowy model ojcostwa, (w:) M. Dąbrowska, A. Radomski (red.), Męskość jako kategoria kulturowa. Praktyki męskości, Wydawnictwo Portalu Wiedza i Edukacja, Lublin.

GUS, 2014, Aktywność ekonomiczna ludności Polski. IV kwartał 2013 r., Warszawa.

Hałas Elżbieta, 1981, Symboliczny interakcjonizm - wielość orientacji a podstawy jedności perspektywy, „Studia Socjologiczne”, nr 4(83).

Hałas Elżbieta, 2006a, Interakcjonizm symboliczny. Społeczny kontekst znaczeń (Wydanie nowe), Państwowe Wydawnictwo Naukowe, Warszawa.

Hałas Elżbieta, 2006b, Klasyczna socjologia kulturowa: nowe odczytanie spuścizny F. Znanieckiego, (w:) J. Mucha, W. Wincławski (red.), Klasyczna socjologia polska i jej współczesna recepcja, Wydawnictwo Uniwersytetu Mikołaja Kopernika, Torun.

Hearn Jeff, 2003, „Surprise, surprise, men are gendered too”: Critical Studies on Men and the Politics of Representation, (w:) E. Oleksy (ed.), Representing Gender in Cultures, Peter Lang, Frankfurt.

Hearn Jeff, 2008, Patriarchaty, transpatriarchaty i punkty krzyżowania się kategorii spolecznych, (w:) E. Oleksy (red.), Tożsamość i obywatelstwo w społeczeństwie wielokulturowym, Państwowe Wydawnictwo Naukowe, Warszawa.

Hines Sally, 2008, (Trans)formacja gender: zmiana spoleczna i transgenderowe obywatelstwo, (w:) E. Oleksy (red.), Tożsamość i obywatelstwo w społeczeństwie wielokulturowym, Państwowe Wydawnictwo Naukowe, Warszawa.

Hofstede Geert, 2000, Kultury i organizacje, Polskie Wydawnictwo Ekonomiczne, Warszawa.

Hryciuk Renata E., Korolczuk Elżbieta, 2012, Wstęp. Pożegnanie z Matka Polka, (w:) R.E. Hryciuk, E. Korolczuk (red.), Pożegnanie z Matka Polką? Dyskursy, praktyki i reprezentacje macierzyństwa we współczesnej Polsce, Wydawnictwo Uniwersytetu Warszawskiego, Warszawa.

Humm Maggie, 1993, Stownik teorii feminizmu, Wydawnictwo Semper, Warszawa.

Hyży Ewa, 2003, Kobieta, ciało, tożsamość. Teorie podmiotu w filozofii feministycznej końca XX wieku, Wydawnictwo Universitas, Kraków.

Hyży Ewa, 2010, Chrześcijański ruch Promise Keepers a „kryzys męskości”. Perspektywa feministyczna, (w:) M. Dąbrowska, A. Radomski (red.), Męskość jako kategoria kulturowa. Praktyki męskości, Wydawnictwo Portalu Wiedza i Edukacja, Lublin.

Inglehart Ronald, Norris Pippa, 2009, Wzbierająca fala. Równouprawnienie płci a zmiana kulturowa na świecie, Państwowy Instytut Wydawniczy, Warszawa.

Jankowska Maria, 2009, Świat ucznia - świat uczennicy. Socjalizacja szkolna a utrwalanie spotecznych ról plciowych, (w:) E. Malinowska E. (red.), Polskie społeczeństwo patriarchalne w procesie zmian, „Acta Universitatis Lodziensis”, Folia Sociologica 34.

Janukowicz Maria, 2002, Czy współczesne ojcostwo to ojcostwo nieobecne?, „Małżeństwo i Rodzina", nr 1.

Jarymowicz Tomasz, 2007, Queer theory - bardzo krótki wstęp, (w:) M. Dąbrowski, R. Pruszczyński (red.), Lektury inności. Antologia, Dom Wydawniczy Elipsa, Warszawa. 
Jedliński Krzysztof, 1998, Wychowanie w rodzinie konieczna droga do ojcostwa, (w:) J. Augustyn SI (red.), Ojcostwo, Wydawnictwo WAM, Kraków.

Johansson Thomas, Klinth Roger, 2008, Caring Fathers. The Ideology of Gender Equality and Masculine Positions, „Men and Masculinities”, vol. 11, no 1.

Jump Teresa L., Haas Linda, 1987, Fathers in Transition. Dual-Career Fathers Participating in Child Care, (w:) M.S. Kimmel (ed.), Changing men: new directions in research on men and masculinity, Sage Publications, Newbury Park.

Kalus Alicja, 2002, Bezdzietność w matżeństwie, Redakcja Wydawnictw Wydziału Teologicznego Uniwersytetu Opolskiego, Opole.

Kaniewski Sebastian, 2009, Rola i miejsce kobiety w społeczeństwie wedtug Katolickiej Nauki Społecznej, (w:) M. Musiał-Karg (red.), Kobiety we współczesnej Europie. Rola i miejsce kobiet na rynku pracy, w polityce i społeczeństwie, Wydawnictwo Adam Marszałek, Toruń.

Kaschack Ellyn, 1996, Nowa psychologia kobiety. Podejście feministyczne, Gdańskie Wydawnictwo Psychologiczne, Gdańsk.

Katechizm Kościoła Katolickiego, 1998, Wydawnictwo Pallottinum, Poznań.

Kawka Zdzisława, 1998, Między misją a frustracją. Społeczna rola nauczyciela, Wydawnictwo Uniwersytetu Łódzkiego, Łódź.

Kimmel Michael, 2004, The Gendered Society, Oxford University Press, New York.

Kimmel Michael S., 1987, Rethinking masculinity: new directions in research, (w:) M.S. Kimmel (ed.), Changing men: new directions in research on men and masculinity, Sage Publications, Newbury Park.

Kimmel Michael S., Kaufman Michael, 2003, Niedzielni wojownicy: nowy ruch mężczyzn, (w:) M.R. Walsh (red.), Kobiety, mężczyźni i płeć: debata w toku, Wydawnictwo Instytutu Filozofii i Socjologii PAN, Warszawa.

Klimczak-Ziółek Jolanta, 2005, Udział mass mediów w przeobrażaniu wzorców kobiecych, (w:) E. Durys, E. Ostrowska (red.), Gender: wizerunki kobiet i mężczyzn w kulturze, Wydawnictwo Rabid, Kraków.

Klimczak-Ziółek Jolanta, 2006, Kobiecość jako konstrukt kulturowy dyskursu medialnego, (w:) E. Jurczyńska-McCluskey, K. Piątek (red.), Między tradycją a nowoczesnościa, Wydawnictwo Wyższej Szkoły Techniczno-Humanistycznej, Bielsko-Biała.

Kluczyńska Urszula, 2009, Metamorfozy tożsamości mężczyzn w kulturze wspótczesnej, Wydawnictwo Adam Marszałek, Toruń.

Kłoskowska Antonina, 1959, Modele społeczne i kultura masowa, „Przegląd Socjologiczny”, t. XIII, nr 2.

Kłoskowska Antonina, 1960, Badanie modelu rodziny w tódzkim środowisku robotniczym, „Przegląd Socjologiczny" t. XIV, nr 1.

Kłoskowska Antonina, 1962, Wzory i modele w socjologicznych badaniach rodziny, „Studia Socjologiczne", $\mathrm{nr} 2$.

Kłoskowska Antonina, 1980, Kultura masowa, Państwowe Wydawnictwo Naukowe, Warszawa.

Kłoskowska Antonina, 2007, Socjologia kultury, Państwowe Wydawnictwo Naukowe, Warszawa.

Kociołek Piotr, 1998, Odkrywanie daru ojcostwa, (w:) J. Augustyn SI (red.), Ojcostwo, Wydawnictwo WAM, Kraków.

Kochanowski Jacek, 2009, Spektakl i wiedza: perspektywa społecznej teorii queer, Wydawnictwo Wschód-Zachód, Łódź.

Kochanowski Jacek, 2010, Queer studies - wprowadzenie, (w:) J. Kochanowski, M. Abramowicz, R. Biedroń (red.), Queer studies. Podręcznik kursu, Kampania Przeciw Homofobii, Warszawa.

Kodeks pracy, 2015, Wydawnictwo Infor Biznes, Warszawa.

Kołodziej-Durnaś Agnieszka, 2004, O teorii strukturacji Anthony'ego Giddensa jako poszukiwaniu trzeciej drogi w naukach społecznych, Wydawnictwo Naukowe Uniwersytetu Szczecińskiego, Szczecin. 
Konecki Krzysztof, 2000, Studia z metodologii badań jakościowych. Teoria ugruntowana, Państwowe Wydawnictwo Naukowe, Warszawa.

Konstytucja Rzeczpospolitej Polskiej, 1997, Wydawnictwo Sejmowe, Warszawa.

Kornas-Biela Dorota, 1998, Macierzyństwo we wspótczesnej cywilizacji a nauczanie Jana Pawła II, (w:) J. Augustyn SI (red.), Macierzyństwo, Wydawnictwo WAM, Kraków.

Kornas-Biela Dorota (red.), 1999, Oblicza macierzyństwa, Redakcja Wydawnictw Katolickiego Uniwersytetu Lubelskiego, Lublin.

Kornas-Biela Dorota, 2001, Współczesny kryzys ojcostwa, (w:) D. Kornas-Biela (red.), 2001, Oblicza ojcostwa, Towarzystwo Naukowe Katolickiego Uniwersytetu Lubelskiego, Lublin.

Kornas-Biela Dorota (red.), 2001, Oblicza ojcostwa, Towarzystwo Naukowe Katolickiego Uniwersytetu Lubelskiego, Lublin.

Korolczuk Elżbieta, 2012, Ciało z ciała matki? Konstruowanie macierzyństwa i seksualności w kontekście międzypokoleniowym, (w:) R.E. Hryciuk, E. Korolczuk (red.), Pożegnanie z Matka Polka? Dyskursy, praktyki i reprezentacje macierzyństwa we współczesnej Polsce, Wydawnictwo Uniwersytetu Warszawskiego, Warszawa.

Kostrzewski Leszek, Miączyński Piotr, 2014, Ojciec Polak dziękuje za taki urlop rodzicielski, „Gazeta Wyborcza”, 30.09.2014.

Kotowska Irena, 2005, Przemiany rodziny: Polska a Europa, (w:) I. Wóycicka (red.), Szanse na wzrost dzietności - jaka polityka rodzinna, Polskie Forum Strategii Lizbońskiej, Gdańsk.

Kotowska Irena E., Giza-Poleszczuk Anna, 2010, Zmiany demograficzno-społeczne i ich wptyw na rekonceptualizacje polityki rodzinnej w kierunku równowagi $w$ zakresie ochrony praw rodziny i poszczególnych jej członków. Polska na tle Europy, (w:) E. Leś, S. Bernini (red.), Przemiany rodziny w Polsce $i$ we Włoszech i ich implikacje dla polityki rodzinnej, Wydawnictwo Uniwersytetu Warszawskiego, Warszawa.

Kotowska Irena, Sztanderska Urszula, Wóycicka Irena, 2007, Podsumowanie i rekomendacje, (w:) (red.) I.E. Kotowska, U. Sztanderska, I. Wóycicka, Aktywność zawodowa i edukacyjna a obowiazki rodzinne $w$ Polsce $w$ świetle badań empirycznych, Wydawnictwo Naukowe Scholar, Warszawa.

Kowalczyk Iza, Piotrowska Joanna, Zierkiewicz Edyta, 2007, Środki masowego przekazu, (w:) Polityka równości ptci. Polska 2007, Raport UNDP, Warszawa, http://www.bezuprzedzen.org/doc/ polityka_rownosci_plci_raport.pdf (01.11.2014).

Kowalczyk Iza, Piotrowska Joanna, Zierkiewicz Edyta, 2009, Nierówne media, (w:) Raport. Kobiety dla Polski Polska dla kobiet. 20 lat transformacji 1989-2009, Fundacja Feminoteka, Warszawa, www.kongreskobiet.pl (01.11.2014).

Krajewska Anna, 2008, Konteksty ojcostwa, (w:) M. Fuszara (red.), Nowi mężczyźni? Zmieniające się modele męskości we wspótczesnej Polsce, Wydawnictwo Trio, Warszawa.

Krasuska Karolina, 2008, Gra w przektad, (w:) Butler J., Uwikłani w płeć, Wydawnictwo Krytyki Politycznej, Warszawa.

Król Marcin, 1999, Stownik demokracji, Prószyński i S-ka, Warszawa.

Kryczka Piotr, 1997, Zmiany ról rodzinnych w rodzinach bezrobotnych, (w:) P. Kryczka (red.), Rodzina w zmieniającym się społeczeństwie, Redakcja Wydawnictw Katolickiego Uniwersytetu Lubelskiego, Lublin.

Krzak Zygmunt, 2007, Od matriarchatu do patriarchatu, Wydawnictwo Trio, Warszawa.

Krzyszkowski Jerzy, 1989, Uwarunkowania realizacji modelu partnerskiego w matżeństwie, „Problemy Rodziny", nr 6.

Kubicki Paweł, 2009, Przemiany ojcostwa we współczesnej Polsce, (w:) M. Sikorska (red.), Być rodzicem we wspótczesnej Polsce. Nowe wzory w konfrontacji z rzeczywistościa, Wydawnictwo Uniwersytetu Warszawskiego, Warszawa. 
Kudrycka Barbara, Kopeć Agnieszka, 2009, Fenomen kobiety we współczesnym świecie, (w:) E. Ozorowski, R.Cz. Horodeński (red.), Kobieta. Etyka. Ekonomia, Wydawnictwo Wyższej Szkoły Ekonomicznej w Białymstoku, Białystok.

Kvale Steinar, 2004, InterViews. Wprowadzenie do jakościowego wywiadu badawczego, Wydawnictwo TransHumana, Białystok.

Kwak Anna, 2005, Rodzina w dobie przemian. Matżeństwo i kohabitacja, Wydawnictwo Akademickie Żak, Warszawa.

Kwak Anna, 2007, Kobieta $w$ domu i na rynku pracy. Czy równość praw i obowiazków?, (w:) A. Kotlarska-Michalska (red.), Wizerunki ról rodzinnych, „Roczniki Socjologii Rodziny” nr XVIII.

Kwiatkowska Anna, Nowakowska Agnieszka, 2006, Mężczyzna polski. Psychospołeczne czynniki warunkujące petnienie ról zawodowych i rodzinnych, Wydawnictwo Wyższej Szkoły Ekonomicznej w Białymstoku, Białystok.

Levinson Daniel J., 1978, Rola, osobowość i struktura społeczna, (w:) J. Szmatka (red.), Elementy mikrosocjologii, Wydawnictwo Uniwersytetu Jagiellońskiego, Kraków.

Linton Ralph, 2000, Kulturowe podstawy osobowości, Państwowe Wydawnictwo Naukowe, Warszawa.

Lott Bernice, Maluso Diane, 2002, Społeczne uczenie się męskości i kobiecości, (w:) B. Wojciszke (red.), Kobiety i mężczyźni: odmienne spojrzenia na różnice, Gdańskie Wydawnictwo Psychologiczne, Gdańsk.

Lutyński Jan, 1994, Metody badań społecznych, Łódzkie Towarzystwo Naukowe, Łódź.

Łacek Maria, 2004, Model koncepcyjny roli społecznej w perspektywie interakcjonistycznej, (w:) D. Niczyporuk (red.), Stare i nowe struktury społeczne $w$ Polsce, t. 5: Terytorialne struktury społeczne, Wydawnictwo Uniwersytetu Marii Curie-Skłodowskiej, Lublin.

Łaciak Beata, 2005, Obyczajowość polska czasu transformacji, czyli wojna postu z karnawatem, Wydawnictwo Trio, Warszawa.

Łaciak Beata, 2007, Medialny obraz mężczyzn w relacjach matżeńskich i rodzinnych, (w:) M. Fuszara (red.) Nowi mężczyźni? Zmieniające się modele męskości we współczesnej Polsce, Wydawnictwo Trio, Warszawa.

Łaciak Beata, 2012, Ciąża i macierzyństwo. Serialowe reprezentacje jako element społecznego dyskursu, (w:) R.E. Hryciuk, E. Korolczuk (red.), Pożegnanie z Matka Polka? Dyskursy, praktyki i reprezentacje macierzyństwa we wspótczesnej Polsce, Wydawnictwo Uniwersytetu Warszawskiego, Warszawa.

Łoś Maria, 1985, Role społeczne w nowej roli, (w:) O społeczeństwie i teorii społecznej. Ksiegga pamiątkowa $S$. Ossowskiego, Państwowe Wydawnictwo Naukowe, Warszawa.

Machaj Irena, 2009, Męskość i kobiecość - społeczne definiowanie relacji, (w:) I. Machaj, R. Suchocka (red.), Męskość i kobiecość. Czy walka ptci?, Wyższa Szkoła Nauk Humanistycznych i Dziennikarstwa, Poznań.

Macintyre Sally, 1982, Kto chce dzieci? Społeczne fabrykowanie „instynktów”, (w:) T. Hołówka (red.), Nikt nie rodzi się kobieta, Czytelnik, Warszawa.

Maison Dominika, 2000, Zogniskowane wywiady grupowe. Jakościowa metoda badań marketingowych, Państwowe Wydawnictwo Naukowe, Warszawa.

Malinowska Ewa, 2000, Feminizm europejski, demokracja parytetowa a polski ruch kobiet, Wydawnictwo Uniwersytetu Łódzkiego, Łódź.

Malinowska Ewa, 2003, Mężczyźni i kobiety w społeczeństwie jutra, „Kultura i Społeczeństwo”, nr 4.

Malinowska Ewa, 2009, Konflikt ptci jako konflikt społeczny. Od „kwestii kobiecej” do problemu: demokracja bez egalitaryzmu?, (w:) I. Machaj, R. Suchocka (red.), Męskość i kobiecość. Czy walka ptci?, Wyższa Szkoła Nauk Humanistycznych i Dziennikarstwa, Poznań. 
Malinowski Hubert, 2004, Komunikacja w zogniskowanym wywiadzie grupowym, (w:) J. Lisek-Michalska, P. Daniłowicz (red.), Zogniskowany wywiad grupowy. Studia nad metoda, Wydawnictwo Uniwersytetu Łódzkiego, Łódź.

Mandal Eugenia, 1995, Socjalizacja ról społecznych związanych z płcia, (w:) E. Mandal, R. Stefańska-Klar (red.), Współczesne problemy socjalizacji, Wydawnictwo Uniwersytetu Śląskiego, Katowice.

Mandal Eugenia, 2000, Podmiotowe i interpersonalne konsekwencje stereotypów zwiqzanych z płcia, Wydawnictwo Uniwersytetu Śląskiego, Katowice.

Mandal Eugenia, 2003, Kobiecość i męskość. Popularne opinie a badania naukowe, Wydawnictwo Naukowe „Żak”, Warszawa.

Mandal Eugenia, 2005, Kobiecość i męskość w psychologii, (w:) A. Barska, E. Mandal (red.), Tożsamość społeczno-kulturowa ptci, Wydawnictwo Uniwersytetu Opolskiego, Opole.

Martin Karin A., 2005, William Wants A Doll. Can He Have One? Feminists, Child Care Advisors, and Gender-Neutral Child Rearing, „Gender\&Society”, no 19.

Matysiak A., 2007, Indywidualne przesłanki zwiększania aktywności zawodowej, (w:) I.E. Kotowska, U. Sztanderska, I. Wóycicka (red.), Aktywność zawodowa i edukacyjna a obowiązi rodzinne w Polsce w świetle badań empirycznych, Wydawnictwo Naukowe Scholar, Warszawa.

Mead George H., 1975, Umyst, osobowość i społeczeństwo, Państwowe Wydawnictwo Naukowe, Warszawa.

Mead Margaret, 1986, Pleć i charakter w trzech społecznościach pierwotnych, Państwowy Instytut Wydawniczy, Warszawa.

Melosik Zbyszko, 2002, Kryzys męskości w kulturze wspótczesnej, Wydawnictwo Wolumin, Poznań.

Mierzwiński Bronisław, 1999, Mężczyzna istota nieznana, Oficyna Wydawniczo-Poligraficzna Adam, Warszawa.

Miluska Jolanta, 1996, Tożsamość kobiety i mężczyzny w cyklu życia, Wydawnictwo Naukowe Uniwersytetu Adama Mickiewicza, Poznań.

Miluska Jolanta, Boski Paweł, 1999, Męskossć - kobiecość: Zarys i poziomy analizy problematyki, (w:) J. Miluska, P. Boski (red.), Męskość - kobiecość w perspektywie indywidualnej i kulturowej, Wydawnictwo Instytutu Psychologii PAN, Warszawa.

Minkiewicz Karolina, 2006, Metroseksualność jako współczesny model męskości, (w:) Obrazy życia rodzinnego z perspektywy interdyscyplinarnej, „Roczniki Socjologii Rodziny”, nr XVII.

Mizielińska Joanna, 2008, Pomiędzy nowym a starym: feminizm wobec wyzwań współczesności, „Societas/Communitas”, nr 2.

Moir Anne, Jessel David, 1993, Pteć mózgu, Państwowy Instytut Wydawniczy, Warszawa.

Monczka-Ciechomska Magda, 1992, Mit kobiety w polskiej kulturze, (w:) S. Walczewska (red.), Gtos maja kobiety, Convivium, Kraków.

Monkiewicz-Święcicka Karolina, 2005, Tacierzyństwo, „Przegląd”, nr 9.

Moore Henrietta L., 2005, Płeć kulturowa i status - wyjaśnienie sytuacji kobiet, (w:) M. Kempny, E. Nowicka (red.), Badanie kultury. Elementy teorii antropologicznej, Państwowe Wydawnictwo Naukowe, Warszawa.

Muczyński Maciej, Żynel Małgorzata, 2006, Analiza potrzeb rodziców w zakresie organizacji opieki nad dziećmi w świetle rozwiazań sprzyjających godzeniu życia zawodowego i rodzinnego, Wydawnictwo Wyższej Szkoły Ekonomicznej w Białymstoku, Białystok.

Nelson Todd D., 2003, Psychologia uprzedzeń, Gdańskie Wydawnictwo Psychologiczne, Gdańsk.

Nicińska Magdalena, 2000, Indywidualne wywiady pogłębione i zogniskowane wywiady grupowe - analiza porównawcza, „ASK”, $\mathrm{nr} 8$.

Nowalska-Kapuścik Dorota, 2010, Macierzyństwo w epoce zmian - tradycyjna wartość czy nowy obszar konsumpcyjnej działalności?, (w:) W. Muszyński (red.), Wartości w rodzinie: ciagłość i zmiana, Wydawnictwo Adam Marszałek, Toruń. 
Olcoń Kubicka Marta, 2009, Rola internetu w powstawaniu nowego modelu macierzyństwa, (w:) M. Sikorska (red.), Być rodzicem we wspótczesnej Polsce. Nowe wzory w konfrontacji z rzeczywistościa, Wydawnictwo Uniwersytetu Warszawskiego, Warszawa.

Ortner Sherry B., 1982, Czy kobieta ma się tak do mężczyzny, jak „natura” do „kultury”?, (w:) T. Hołówka (red.), Nikt nie rodzi się kobieta, Czytelnik, Warszawa.

Ossowska Maria, 2000, Ethos rycerski i jego odmiany, Państwowe Wydawnictwo Naukowe, Warszawa.

Ossowska Maria, 2005, Socjologia moralności. Zarys zagadnień, Państwowe Wydawnictwo Naukowe, Warszawa.

Ostrouch Joanna, 2004, Nieuchwytne. Relacje matek i córek w codzienności, Wydawnictwo Uniwersytetu Warmińsko-Mazurskiego, Olsztyn.

Ozorowski Edward abp, 2009, Geniusz kobiety wedtug Jana Pawła II, (w:) E. Ozorowski, R.Cz. Horodeński (red.), Kobieta. Etyka. Ekonomia, Wydawnictwo Wyższej Szkoły Ekonomicznej w Białymstoku, Białystok.

Pakszys Elżbieta, 2000, Między natura a kulturą: kategoria płci/rodzaju w poznaniu. Studium epistemologii naturalizowanej w perspektywie feministycznej, Wydawnictwo Naukowe Uniwersytetu Adama Mickiewicza, Poznań.

Pakszys Elżbieta, 2009, Feminizm versus humanizm? O nowe rozumienie równości płci, (w:) B. Budrowska (red.), Kobiety. Feminizm. Demokracja, Wydawnictwo Instytutu Filozofii i Socjologii PAN, Warszawa.

Pankowska Dorota, 2005, Wychowanie a role ptciowe, Gdańskie Wydawnictwo Psychologiczne, Gdańsk.

Parsons Talcott, 1969, Struktura społeczna a osobowość, Polskie Wydawnictwo Eekonomiczne, Warszawa.

Parsons Talcott, 1972, Szkice z teorii socjologicznej, Państwowe Wydawnictwo Naukowe, Warszawa. Parsons Talcott, 2009, System społeczny, Zakład Wydawniczy „Nomos”, Kraków.

Piotrowski Andrzej, 1981, Negocjacyjny model interakcji, „Przegląd Socjologiczny”, t. XXXIII.

Piątek Katarzyna, 2007, Nowy wymiar ojcostwa jako nowy wymiar męskości, (w:) K. Piątek (red.), Męskość (nie)męska. Współczesny mężczyzna w zmieniajacej się rzeczywistości społecznej, Wydawnictwo Akademii Techniczno-Humanistycznej w Bielsku-Białej, Bielsko-Biała.

Piszczatowska Mariola, Szczepańska Joanna, 2008, Kobiety w życiu publicznym i rodzinie. Opinie Polaków i stan faktyczny w świetle badań socjologicznych, „Societas/Communitas”, nr 2(6).

Pleck Josef H., 1987, American Fathering in Historical Perspective, (w:) M.S. Kimmel (ed.), Changing men: new directions in research on men and masculinity, Sage Publications, Newbury Park.

Poleszczuk Jan, 2002, Rodzina, matzeństwo, prokreacja: racjonalizacja strategii reprodukcyjnych, (w:) A. Jasińska-Kania, M. Marody (red.), Polacy wśród Europejczyków. Wartości społeczeństwa polskiego na tle innych krajów europejskich, Wydawnictwo Naukowe Scholar, Warszawa.

Pospiszyl Kazimierz, 1998, Kontrowersje wokót ideału męskości, „Problemy Rodziny”, nr 2.

Pospiszyl Kazimierz, 2004, Ojcostwo w życiu mężczyzny, „Małżeństwo i Rodzina”, nr 2.

Pospiszyl Kazimierz, 2007, Ojciec a wychowanie dziecka, Wydawnictwo Naukowe „Żak”, Warszawa.

Pszczółkowska Dominika, 2010, Kobiety wracają do kuchni, „Wysokie Obcasy” - dodatek do „Gazety Wyborczej”, dostępny w Internecie (01.03.2011): http://www.wysokieobcasy.pl/wysokie-obcasy/1,53664,8060257,Kobiety_wracaja_do_kuchni.html

Przybyłowska Ilona, 1978, Wywiad swobodny ze standaryzowana lista poszukiwanych informacji i możliwości jego zastosowania w badaniach socjologicznych, „Przegląd Socjologiczny”, t. XXX.

Pulikowski Jacek, 2010, Warto być ojcem. Najważniejsza kariera mężczyzny, Inicjatywa Wydawnicza „Jerozolima”, Poznań. 
Putnam Tong Rosemarie, 2002, Myśl feministyczna. Wprowadzenie, Państwowe Wydawnictwo Naukowe, Warszawa.

Regosz-Kaczkowska Małgorzata, Minkowski Piotr, 2000, Uczestnictwo ojca w porodzie „Problemy Rodziny", nr 6.

Renzetti Claire M., Curran Daniel J., 2005, Kobiety, mężczyźni i społeczeństwo, Państwowe Wydawnictwo Naukowe, Warszawa.

Reszke Irena, 1991, Nierówności ptci w teoriach, Wydawnictwo Instytutu Filozofii i Socjologii PAN, Warszawa.

Ritzer George, 2004, Klasyczna teoria socjologiczna, Wydawnictwo Zysk i S-ka, Poznań.

Ronek Grzegorz, 2008, Koncepcja demokratycznej rodziny Anthony'ego Giddensa, (w:) W. Muszyński, E. Sikora (red.), Miłość, wierność i uczciwość na rozstajach współczesności. Ksztalty rodziny wspótczesnej, Wydawnictwo Adam Marszałek, Toruń.

Roszak J., 2015, Kobieta w Polsce. Matka jest tylko jedna, „Wysokie Obcasy”, dodatek do „Gazety Wyborczej”, 24.01.2015 r., Dostępny w Internecie (23.06.2015), http://www.wysokieobcasy. pl/wysokie-obcasy/1,96856,17253335,Kobieta_w_Polsce_Matka_jest_tylko_jedna.html

Rubin Herbert J., Rubin Irene S., 1997, Jak zmierzać do celu nie wiążac sobie rąk. Projektowanie wywiadów jakościowych, (w:) L. Korporowicz (red.), Ewaluacja w edukacji, Oficyna Naukowa, Warszawa.

Saxonberg Steven, 2010, Polityki rodzinne w nowych państwach członkowskich Unii Europejskiej i ich wplyw na role wynikajace z ptci oraz prawa jednostki, (w:) E. Leś, S. Bernini (red.), Przemiany rodziny $w$ Polsce $i$ we Włoszech $i$ ich implikacje dla polityki rodzinnej, Wydawnictwo Uniwersytetu Warszawskiego, Warszawa.

Sekuła-Kwaśniewicz Halina, 2000, Płeć, (w:) Encyklopedia socjologii, t. III, Oficyna Wydawnicza, Warszawa.

Servan-Schreiber Perla, 1998, Kobiecość. Od wolności do szczęścia, Książka i Wiedza, Warszawa.

Siemieńska Renata, 2004, Od wartości postmaterialistycznych do materialistycznych - casus Polski, (w:) M. Marody (red.), Zmiana czy stagnacja? Społeczeństwo polskie po czternastu latach transformacji, Wydawnictwo Naukowe Scholar, Warszawa.

Siemieńska Renata, 2007a, Kontrakt ptci. Między sfera prywatna i publiczna, (w:) A. Kojder (red.), Jedna Polska? Dawne i nowe zróżnicowania społeczne, Wydawnictwo WAM, Kraków.

Siemieńska Renata, 2007b, Przemiany ptci kulturowej. Między systemami wartości a rolami społecznymi, (w:) Mirosława Marody (red.), Wymiary życia społecznego. Polska na przełomie XX $i$ XXI wieku. Wydanie nowe, Wydawnictwo Naukowe Scholar, Warszawa.

Sikora Ewa, 2008, Społeczne oczekiwania wobec zwiazku i partnera życiowego - kierunki zmian, (w:) W. Muszyński, E. Sikora (red.), Miłość, wierność i uczciwość na rozstajach współczesności. Ksztalty rodziny wspótczesnej, Wydawnictwo Adam Marszałek, Torun.

Sikorska Małgorzata, 2009a, Nowa matka, nowy ojciec, nowe dziecko. O nowym układzie sił w polskich rodzinach, Wydawnictwo Akademickie i Profesjonalne, Warszawa.

Sikorska Małgorzata, 2009b, Matka „chora” zamiast „złej”- o nowych wzorach macierzyństwa, (w:) M. Sikorska (red.), Być rodzicem we wspótczesnej Polsce. Nowe wzory w konfrontacji z rzeczywistościa, Wydawnictwo Uniwersytetu Warszawskiego, Warszawa.

Silverman David, 2007, Interpretacja danych jakościowych: metody analizy rozmowy, tekstu i interakcji, Państwowe Wydawnictwo Naukowe, Warszawa.

Skowrońska Alicja, 2008, Rodzicielstwo nastolatków życiowym sukcesem czy porażka? Subiektywne znaczenie wczesnego macierzyństwa i ojcostwa (doniesienie z badań), (w:) W. Muszyński, E. Sikora (red.), Miłość, wierność i uczciwość na rozstajach współczesności. Kształty rodziny współczesnej, Wydawnictwo Adam Marszałek, Torun.

Slany Krystyna, 2008, Alternatywne formy życia matżénsko-rodzinnego w ponowoczesnym świecie, Zakład Wydawniczy „Nomos”, Kraków. 
Šmidová Iva, 2008, Zmiana pojęcia męskości w Czechach? O mężczyznach „przyjaznych dzieciom i środowisku”, (w:) E.Oleksy (red.), Tożsamość i obywatelstwo w społeczeństwie wielokulturowym, Państwowe Wydawnictwo Naukowe, Warszawa.

Sobczyńska Danuta, 1995, Macierzyństwo: wartości i dylematy, (w:) J. Miluska, E. Pakszys (red.), Humanistyka i płeć I. Studia kobiece z psychologii, filozofii i historii, Wydawnictwo Naukowe Uniwersytetu Adama Mickiewicza, Poznań.

Stańczak-Wiślicz Katarzyna, 2012, Matki biedne, nieszczęśliwe, złe. Luki dominującego dyskursu macierzyństwa w popularnych magazynach kobiecych, (w:) R.E. Hryciuk, E. Korolczuk (red.), Pożegnanie z Matka Polką? Dyskursy, praktyki i reprezentacje macierzyństwa we wspótczesnej Polsce, Wydawnictwo Uniwersytetu Warszawskiego, Warszawa.

Sternicka Magdalena, 2008, Rodzina egalitarna - zmierzch hierarchii?, (w:) W. Muszyński, E. Sikora (red.), Miłość, wierność i uczciwość na rozstajach wspólczesności. Kształty rodziny wspótczesnej, Wydawnictwo Adam Marszałek, Torun.

Stojanowska Elżbieta, 2008, Stereotypy i różnorodność płciowa, „Przegląd Powszechny”, nr 7-8.

Szacki Jerzy, 2005, Historia myśli socjologicznej (Wydanie nowe), Państwowe Wydawnictwo Naukowe, Warszawa.

Szarzyńska Małgorzata, 2005, „, Obyś żył w ciekawszych czasach”. Czy zmiany w rozumieniu kategorii płci zmienia nasze społeczeństwo?, (w:) A. Barska, E. Mandal (red.), Tożsamość społeczno-kulturowa ptci, Wydawnictwo Uniwersytetu Opolskiego, Opole.

Szczepaniak Monika, 2005, Męskość w opresji? Dylematy męskości w kulturze Zachodu, (w:) E. Durys, E. Ostrowska (red.), Gender. Wizerunki kobiet i mężczyzn w kulturze, Wydawnictwo Rabid, Kraków.

Szczepański Jan, 1970, Elementarne pojęcia socjologii, Państwowe Wydawnictwo Naukowe, Warszawa.

Szlendak Tomasz, 2009, O naskórkowej (lub kosmetycznej) przemianie męskości, (w:) M. Sikorska (red.), Być rodzicem we współczesnej Polsce. Nowe wzory w konfrontacji z rzeczywistościa, Wydawnictwo Uniwersytetu Warszawskiego, Warszawa.

Szlendak Tomasz, 2010, Socjologia rodziny, Państwowe Wydawnictwo Naukowe, Warszawa.

Szmatka Jacek, 1973, Miejsce teorii roli społecznej w systemie teoretycznym socjologii, „Studia Socjologiczne", $\mathrm{nr}$ 3(50).

Szmatka Jacek, 1974, Modele pojęciowe w teorii roli społecznej, „Studia Socjologiczne”, nr 1(52).

Szmatka Jacek, 1989, Małe struktury społeczne. Wstęp do mikrosocjologii strukturalnej, Państwowe Wydawnictwo Naukowe, Warszawa.

Szmatka Jacek, 2000, Rola społeczna, (w:) Encyklopedia socjologii, t. 3, Oficyna Naukowa, Warszawa.

Sztompka Piotr, 1998, Giddens Anthony, (w:) Encyklopedia socjologii, t. 1, Oficyna Naukowa, Warszawa.

Sztompka Piotr, 2002a, Teorie zmiany społecznej, (w:) Encyklopedia socjologii, t. 4, Oficyna Naukowa, Warszawa.

Sztompka Piotr, 2002b, Socjologia. Analiza społeczeństwa, Wydawnictwo Znak, Kraków.

Sztompka Piotr, 2005, Socjologia zmian społecznych, Wydawnictwo Znak, Kraków.

Sztumski Janusz, 2005, Wstęp do metod i technik badań społecznych, Wydawnictwo Śląsk, Katowice.

Szukalski Piotr, Warzywoda-Kruszyńska Wielisława, 2005, Polityka w sferze oświaty $i$ wychowania - bariera i stymulanta pracy zawodowej rodziców, (w:) I. Wóycicka (red.), Szanse na wzrost dzietności - jaka polityka rodzinna, Polskie Forum Strategii Lizbońskiej, Gdańsk.

Szulich-Kałuża Justyna, 2008, Wspótczesne macierzyństwo w dyskursie medialnym - na przykładzie polskiej prasy, (w:) W. Muszyński, E. Sikora (red.), Małżeństwo i rodzina w ponowoczesności. Szanse - zagrożenia - patologie, Wydawnictwo Adam Marszałek, Toruń. 
Szwed Anna, 2009, Kościół rzymskokatolicki o kobiecie. Między teoria a praktyka, (w:) B. Kowalska, K. Zielińska, B. Koschalka (red.), Gender. Kobieta w kulturze i spoleczeństwie, Wydawnictwo Rabid, Kraków.

Ślęczka Kazimierz, 1999, Feminizm, Wydawnictwo „Książnica”, Katowice.

Środa Magdalena, 2007, Kobiety, Kościól, katolicyzm, (w:) Ch. Ockrent (red.), Czarna księga kobiet, Wydawnictwo W.A.B., Warszawa.

Środa Magdalena, Rutkowska Ewa, 2007, Edukacja, (w:) Polityka równości ptci Polska 2007, Raport UNDP, Program Narodów Zjednoczonych ds. Rozwoju, Warszawa.

Titkow Anna, 1995, Kobiety pod presją? Proces ksztattowania się tożsamości, (w:) A. Titkow, H. Domański (red.), Co to znaczy być kobieta w Polsce?, Wydawnictwo Instytutu Filozofii i Socjologii PAN, Warszawa.

Titkow Anna, 1998, Feminizm, (w:) Encyklopedia socjologii, t. 1, Oficyna Naukowa, Warszawa.

Titkow Anna, 2007, Tożsamość polskich kobiet. Ciagłość, zmiana, konteksty, Wydawnictwo Instytutu Filozofii i Socjologii PAN, Warszawa.

Titkow Anna, 2012, Figura Matki Polki. Próba demitologizacji, (w:) R.E. Hryciuk, E. Korolczuk (red.), Pożegnanie z Matka Polka? Dyskursy, praktyki i reprezentacje macierzyństwa we wspótczesnej Polsce, Wydawnictwo Uniwersytetu Warszawskiego, Warszawa.

Titkow Anna, Budrowska Bogusława, Duch Danuta, 2004a, Nieodpłatna praca kobiet, Wydawnictwo Instytutu Filozofii i Socjologii PAN, Warszawa.

Titkow Anna, Budrowska Bogusława, Duch Danuta, 2004b, O konflikcie ptci, (w:) H. Domański, A. Ostrowska, A. Rychard (red.), Niepokoje polskie, Wydawnictwo Instytutu Filozofii i Socjologii PAN, Warszawa.

Titkow Anna, Duch-Krzystoszek Danuta, 2009, Niejednoznaczny status pracy domowej kobiet, (w:) Raport. Kobiety dla Polski Polska dla kobiet. 20 lat transformacji 1989-2009, Fundacja Feminoteka, Warszawa, www.kongreskobiet.pl

Tokarczuk Olga, 2008, Kobieta nie istnieje, (w:) J. Butler, Uwiktani w pteć, Wydawnictwo Krytyki Politycznej, Warszawa.

Turner Jonathan H., 1985, Struktura teorii socjologicznej, Państwowe Wydawnictwo Naukowe, Warszawa.

Turner Jonathan H., 1998, Socjologia: koncepcje i ich zastosowanie, Wydawnictwo Zysk i S-ka, Poznań.

Turner Jonathan H., 2004, Struktura teorii socjologicznej (Wydanie nowe), Państwowe Wydawnictwo Naukowe, Warszawa.

Turner Ralph H., 1962, Role-Taking: Process Versus Conformity, (w:) A.M. Rose (ed.), Human Behavior and Social Processes. An Interactionist Approach, University of Minnesota Houghton Mifflin Company, Boston.

Turner Ralph H., 1985, Unanswered questions in the convergence between structuralist and interactionist role theories, (w:) H.J. Helle, S.N. Eisenstadt (eds.), Micro-Sociological Theory. Perspectives on Sociological Theory, volume 2, SAGE Studies in International Sociology, London.

Turnowiecki Witold, 2009, Polityka rodzinna, (w:) R. Gabryszak, D. Magierek (red.), Wprowadzenie do polityki społecznej, Wydawnictwo Difin, Warszawa.

Turowski Jan, 2005, A. Giddensa teoria strukturacji a teoria konstruktywizmu strukturalnego P. Bourdieu, „Roczniki Nauk Społecznych”, t. XXXIII, z. 1.

Twardowska Anna, Olczyk Eliza, 2000, Kobiety w mediach, (w:) Kobiety w Polsce w latach 90. Raport Centrum Praw Kobiet, Centrum Praw Kobiet, Warszawa.

Uliński Maciej, 2001, Kobieta i mężczyzna. Dzieje refleksji filozoficzno-społecznej, Wydawnictwo Aureus, Kraków.

Umińska Bożena, Mikos Jarosław, 1993, Od tlumaczy, (w:) M. Humm, Słownik teorii feminizmu, Wydawnictwo Semper, Warszawa. 
Urbańska Sylwia, 2009, Profesjonalizacja macierzyństwa jako proces odpodmiotowienia matki. Analiza dyskursów poradnika „,Twoje Dziecko” z 2003 i 1975 roku, (w:) B. Budrowska (red.), Kobiety. Feminizm. Demokracja, Wydawnictwo Instytutu Filozofii i Socjologii PAN, Warszawa.

Urbańska Sylwia, 2012, Naturalna troska o ciało i moralność versus profesjonalna produkcja osobowości. Konstruowanie modelu człowieka $w$ dyskursach macierzyńskich w latach 70. (PRL) i na poczatku XXI wieku, (w:) R.E. Hryciuk, E. Korolczuk (red.), Pożegnanie z Matka Polka? Dyskursy, praktyki i reprezentacje macierzyństwa we współczesnej Polsce, Wydawnictwo Uniwersytetu Warszawskiego, Warszawa.

Vedfelt Ole, 2004, Kobiecość w mężczyźnie, Wydawnictwo Psychologii i Kultury ENETEIA, Warszawa.

Walczewska Sławomira, 2000, Damy, rycerze i feministki, Wydawnictwo eFKa, Kraków.

Walczewska Sławomira, 2001, Trudne słowo gender, „Zadra”, nr 3-4.

Warzywoda-Kruszyńska Wielisława, 2004, Rodzina w procesie zmian, (w:) W. Warzywoda-Kruszyńska, P. Szukalski (red.), Rodzina w zmieniającym się społeczeństwie polskim, Wydawnictwo Uniwersytetu Łódzkiego, Łódź.

Warzywoda-Kruszyńska Wielisława, Krzyszkowski Jerzy, 1990, Młode małżeństwa w wielkim mieście, Instytut Socjologii Uniwersytetu Łódzkiego, CPBP 09.02, Łódź.

Warzywoda-Kruszyńska Wielisława, Krzyszkowski Jerzy, 1991, Problemy ciagłości i zmiany w rodzinach łódzkich - wstępna analiza wyników, (w:) Z. Tyszka (red.), Rodziny polskie o różnym statusie społecznym i środowiskowym, Poznań.

Weber Max, 1985, „Obiektywnośc” poznania w naukach społecznych, (w:) Problemy socjologii wiedzy, Państwowe Wydawnictwo Naukowe, Warszawa.

Wharton Amy S., 2005, The Sociology of Gender. An Introduction to Theory and Research, Blackwell Publishing, Oxford.

Williams Stephen, 2008, What is Fatherhood? Searching for the Reflexive Father, „Sociology”, no. $42(3)$.

Winiarska Aleksandra A., 2008, Mężczyzna. Znaczy: kto?, (w:) A. Radomski, B. Truchlińska (red.), Męskość w kulturze współczesnej, Wydawnictwo Uniwersytetu Marii Curie-Skłodowskiej, Lublin.

Włodarek Jan, Ziółkowski Marek, 1990, Teoretyczny i empiryczny status metody biograficznej we współczesnej socjologii, (w:) J. Włodarek, M. Ziółkowski (red.), Metoda biograficzna w socjologii, Państwowe Wydawnictwo Naukowe, Poznań.

Wnuk-Lipiński Edmund, 2005, Socjologia życia publicznego, Wydawnictwo Naukowe „Scholar”, Warszawa.

Wojciechowska Julita, 2002, Role rodzicielskie wobec zmian uniwersalnych, (w:) K. Appelt, J. Wojciechowska (red.), Zadania i role społeczne w okresie dorosłości, Wydawnictwo Fundacji Humaniora, Poznań.

Wojciszke Bogdan, 2003, Człowiek wśród ludzi. Zarys psychologii społecznej, Wydawnictwo Naukowe Scholar, Warszawa.

Wojtecki Dariusz, 2009, Nowy feminizm w ujęciu nauki społecznej Kościoła, (w:) E. Ozorowski, R.Cz. Horodeński (red.), Kobieta. Etyka. Ekonomia, Wydawnictwo Wyższej Szkoły Ekonomicznej w Białymstoku, Białystok.

Wojnicka Katarzyna, 2010, Od maskulinizmu do profeminizmu. Społeczne ruchy mężczyzn - zarys problematyki, ,uniGender", nr 1, www.unigender.org/?page=biezacy\&issue $=04 \&$ article $=04$

Wóycicka Irena, 2005, Instrumenty polityki rodzinnej w Polsce na tle doświadczeń międzynarodowych, (w:) I. Wóycicka (red.), Szanse na wzrost dzietności - jaka polityka rodzinna, Polskie Forum Strategii Lizbońskiej, Gdańsk.

Wóycicka Joanna, Dominiczak Andrzej, 2000, Edukacja kobiet, (w:) Kobiety w Polsce w latach 90., Raport Centrum Praw Kobiet, Warszawa. 
Wyka Anna, 1989, W poszukiwaniu nowych wzorów badań spolecznych, (w:) A. Sułek, A. Wyka (red.), Poza granicami socjologii ankietowej, Wydawnictwo Instytutu Socjologii Uniwersytetu Warszawskiego, Warszawa.

Zabielski Józef, 2009, Wspólnototwórcza rola kobiety, (w:) E. Ozorowski, R.Cz. Horodeński (red.), Kobieta. Etyka. Ekonomia, Wydawnictwo Wyższej Szkoły Ekonomicznej w Białymstoku, Białystok.

Załęcki Paweł, 2003, Religia i globalizacja - wybrane problemy wzajemnych uwarunkowań, (w:) M. Kempny, G. Woroniecka (red.), Wymiary globalizacji kulturowej. Wyzwania badawcze, Wydawnictwo Wyższej Szkoły Informatyki i Ekonomii TWP w Olsztynie, Olsztyn.

Ziółkowski Marek, 2006, Zmiany systemu wartości, (w:) J. Wasilewski (red.), Wspótczesne społeczeństwo polskie. Dynamika zmian, Wydawnictwo Naukowe Scholar, Warszawa.

Znaniecki Florian, 1971, Nauki o kulturze, Państwowe Wydawnictwo Naukowe, Warszawa.

Znaniecki Florian, 1986, Pojęcie roli społecznej, (w:) J. Szacki, Znaniecki, Wiedza Powszechna, Warszawa.

Znaniecki Florian, 1988, Wstęp do socjologii, Państwowe Wydawnictwo Naukowe, Warszawa.

Znaniecki Florian, 1992, Nauki o kulturze. Narodziny i rozwój, Państwowe Wydawnictwo Naukowe, Warszawa.

Znaniecki Florian, 2008, Metoda socjologii, Państwowe Wydawnictwo Naukowe, Warszawa.

Zygmunt Agata, 2009, Spór o tradycyjny model rodziny w świetle dyskursu na temat równości płci, (w:) E. Malinowska (red.), Polskie społeczeństwo patriarchalne w procesie zmian, „Acta Universitatis Lodziensis", Folia Sociologica, nr 34.

Zyra Anna, 2006, Kobieta sukcesu, żona, matka. Dylematy funkcjonowania kobiet, (w:) J. Ostrouch (red.), Przywiazanie i przekraczanie. Płeć w studiach empirycznych, Uniwersytet Warmińsko-Mazurski, Olsztyn.

\section{Strony internetowe:}

http://www.tato.net, Dostęp 29.09.2015

http://wstroneojca.pl, Dostęp 29.09.2015

http://www.rodzicielski.gov.pl/, Dostęp 01.11.2014

https://rodzina.gov.pl/swiadczenia/ulgi-dla-rodziny, Dostęp 01.11.2014 



\section{Wykaz tabel}

Tabela 1. Treści stereotypów kobiecości i męskości według K. Deaux i L.L. Lewis

Tabela 2. Porównanie tradycyjnego i nowoczesnego modelu płci

Tabela 3. Rodzaje określeń kończących zdania „Kobieta jest...”, „Kobieta powinna być..." z uwzględnieniem płci uczestników

Tabela 4. Rodzaje określeń kończących zdania „Mężczyzna jest...”, „Mężczyzna powinien być..." z uwzględnieniem płci uczestników

Tabela 5. Rodzaje określeń kończących zdania „Bycie matką oznacza...”, „Bycie ojcem oznacza...", z uwzględnieniem płci uczestników 



\section{Od Redakcji}

Doktor Krystyna Dzwonkowska-Godula ukończyła studia magisterskie oraz doktoranckie na kierunku Socjologia na Wydziale Ekonomiczno-Socjologicznym Uniwersytetu Łódzkiego. Autorka rozprawy doktorskiej poświęconej kulturowym modelom i wzorom kobiecości i męskości oraz macierzyństwa i ojcostwa, obronionej w 2012 roku. Adiunkt w Zakładzie Socjologii Płci i Ruchów Społecznych, w Instytucie Socjologii Uniwersytetu Łódzkiego. Uczestniczyła w projektach badawczych podejmujących problematykę stereotypów płci oraz stereotypów ról rodzicielskich; społecznych uwarunkowań procesu powrotu kobiet na rynek pracy po przerwie związanej z wychowaniem dzieci; kapitału ludzkiego i społecznego kobiet i mężczyzn; podmiotowości kobiet w ciąży i w czasie porodu oraz wpływu kulturowych koncepcji płci i wieku na postawy kobiet i mężczyzn wobec zdrowia i wyglądu. Jest autorką i współautorką publikacji poświęconych m.in. społecznym rolom kobiet i mężczyzn, w tym przede wszystkim macierzyństwu i ojcostwu, stereotypom płci oraz nierównościom płci. Przedmiotem jej zainteresowań jest także problematyka kapitału społecznego, zdrowia i praw reprodukcyjnych w perspektywie genderowej. 